\author{
UNITED STATES \\ DEPARTMENT OF THE INTERIOR \\ GEOLOGICAL SURVEY \\ Mail Stop 954, Federal Center, Box 25046 \\ Denver, Colorado 80225
}

\title{
INVENTORY OF GRANITIC MASSES IN \\ THE STATE OF NEVADA
}

Open-file Report 79-235

1979

Prepared by the U.S. Geological Survey

$$
\text { for the }
$$

Nevada Operations Office

U.S. Department of Energy

(Memorandum of Understanding EW-78-A-08-1543) 


\title{
Copies of this open-file Report \\ may be purchased from
}

\author{
Open-File Services Section \\ Branch of Distribution \\ U.S. Geological Survey \\ Box 25425, Federal Center \\ Denver, Colorado 80225
}

PREPAYMENT IS REQUIRED

Price information will be published

in the monthly listing

"New Publications of the Geological Survey"

FOR ADDITIONAL INFORMATION

CALL: Commercial: (303)234-5888

FTS : $234-5888$ 


\author{
UNITED STATES \\ DEPARTMENT OF THE INTERIOR \\ GEOLOGICAL SURVEY
}
INVENTORY OF GRANITIC MASSES IN
THE STATE OF NEVADA
Compiled by

Richard W. Spengler, Florian Maldonado,

J. E. Weir, Jr., W. F. Hanna, and G. L. Dixon 

Abstract-

Introduction-0.-

General statement-1

Definitions of selected terms

Method of study-1

General statement-1 3

Explanation of factors-_. 5

Acknowledgments-1

Clark County-12

Geology-1- 12

Hydrology-1-12

Plutons-1- 14

Lincoln County-

Geology-1-23

Hydrology-1

Plutons-1-

Southern Nye County-

Geology-1 32

Hydrology-

Plutons--

Northern Nye County-

Geology-1 39

Hydrology-1 41

Plutons-1-

Esmeralda County-1

Geology-1 59

Hydrology- 61

Plutons-1-2_- 62

Mineral County-10

Geology-10 79

Hydrology-1-0 79

Plutons-1-

Lyon County- 94

Geology-1- 94

Hydrology-

Plutons-1- 96

Churchil1 County- 106

Geology-106

Hydrology- 106

Plutons-1-0.- 109 


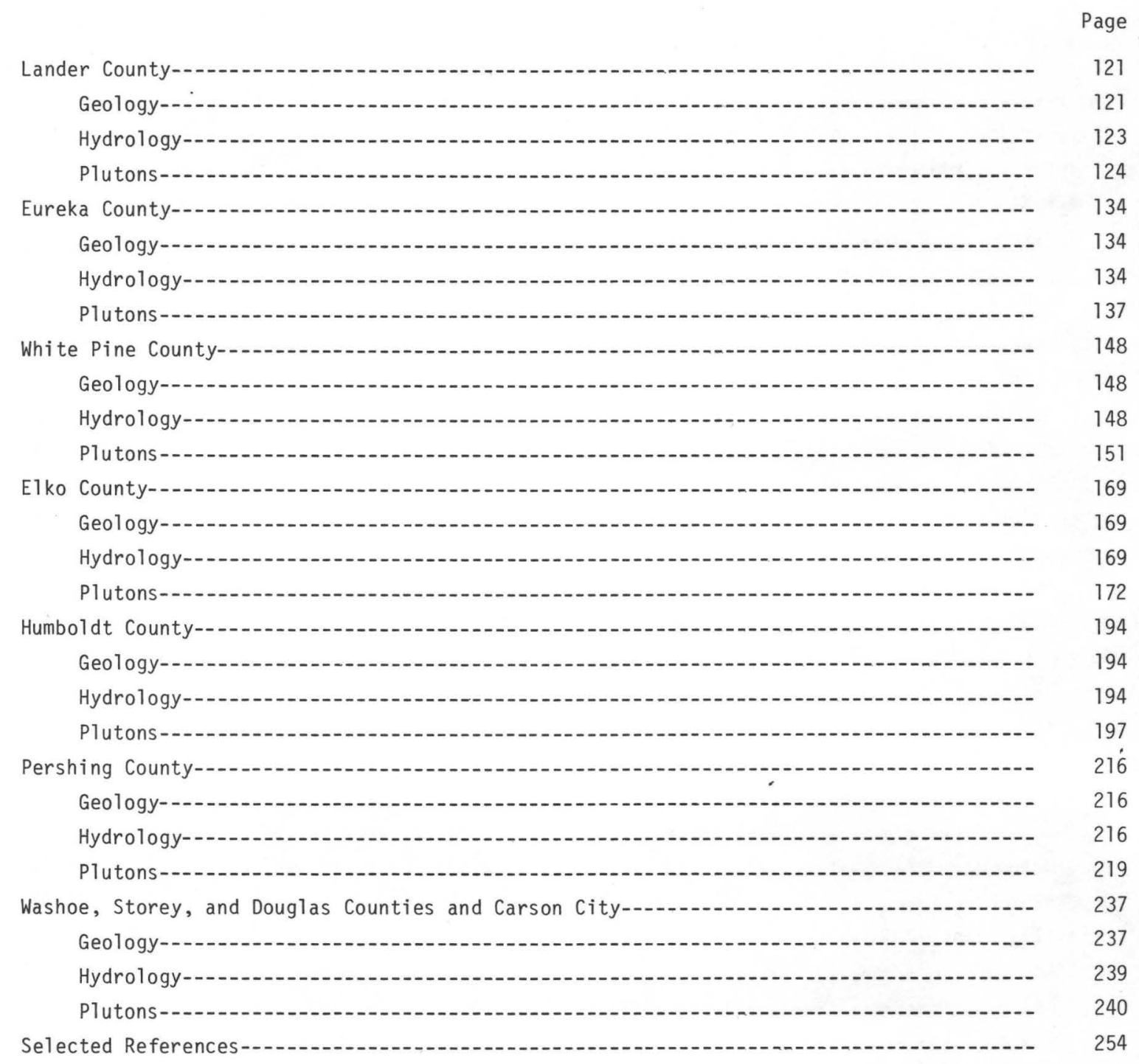




\section{ILLUSTRATIONS}

Page

Plate 1. Topographic map of the State of Nevada-1 pocket]

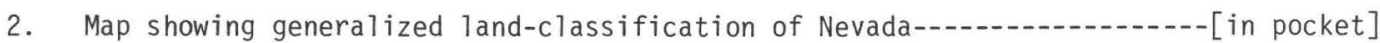

3A. Map showing generalized hydrology of Nevada and other parts of the Great Basin showing areas of ground-water discharge, Pleistocene

lakes and direction of ground-water movement--_-_

3B. Map showing generalized hydrology of Nevada and other parts of the

Great Basin showing ground-water discharge and major sources of

recharge and runoff-_.-_in pocket]

4. Generalized tectonic map of Nevada and parts of California--_-.---_---[in pocket]

5. Preliminary location of epicenters in the State of Nevada and parts

of California--

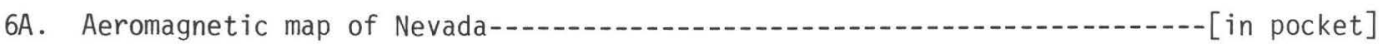

6B. Composite aeromagnetic map of Nevada at 3,810 m above sea leve1------- [in pocket]

7. Map showing distribution of granitic rocks in Nevada--

Figure 1. Index map of Nevada showing location of counties and Nevada Test Site--- 4

2. Diagram showing total-intensity magnetic anomalies associated with rectangular prismatic models having various thicknesses-_-_-_-_-_--- 9

3. Diagram showing total-intensity magnetic anomalies associated with rectangular prismatic models having various directions of total magnetization-- 10

4. Map showing locations of plutons in Clark County-_... 13

5. Map showing locations of plutons in Lincoln County-1 24

6. Map showing locations of plutons in southern Nye County-1-10 33

7. Map showing locations of plutons in northern Nye County--_- 40

8. Map showing locations of plutons in Esmeralda County-10 60

9. Map showing locations of plutons in Mineral County-_-10.- 80

10. Map showing locations of plutons in Lyon County- 95

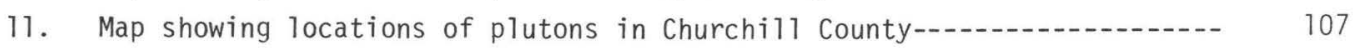

12. Map showing locations of plutons in Lander County-122

13. Map showing locations of plutons in Eureka County-_-_- 135

14. Map showing locations of plutons in White Pine County--149

15. Map showing locations of plutons in Elko County-_... 170

16. Map showing locations of plutons in Humboldt County-195

17. Map showing locations of plutons in Pershing County-1- 217

18. Map showing locations of plutons in Washoe, Storey, and Douglas Counties, and Carson City (Independent City) 


\section{TABLES}

Page

Table 1. Generalized classification of granitic rocks-1

2. Major stratigraphic and time divisions-_- 7 


\author{
UNITED STATES \\ DEPARTMENT OF THE INTERIOR \\ GEOLOGICAL SURVEY \\ Mail Stop 954, Federal Center, Box 25046 \\ Denver, Colorado 80225 \\ INVENTORY OF GRANITIC MASSES IN THE STATE OF NEVADA \\ Compiled by \\ Richard W. Spengler, Florian Maldonado, J. E. Weir, Jr. \\ W. F. Hanna, and G. L. Dixon
}

\begin{abstract}
This report is a compilation of 200 areas of exposed granitic rock within the State of Nevada. Data were compiled on behalf of the Department of Energy to be used in assessing granitic rock as a potential medium for the subsurface storage of radioactive wastes.

The compilation was done on a county-by-county basis. Factors considered for each area of exposed granitic rock are general location, coordinates, land classification, areal extent, accessibility, remoteness, geologic setting, hydrologic setting, aeromagnetic expression, mining activities, general comments, and selected references.
\end{abstract}

\title{
INTRODUCTION
}

\section{General Statement}

This report is a preliminary inventory of exposed granitic masses within the State of Nevada, summarizing geologic, aeromagnetic, hydrologic, and selected geographic information. The study was undertaken at the request of the DOE (Department of Energy) as part of the NTS (Nevada Test Site) Terminal Waste Storage Program to be used in the evaluations of various geologic media for the safe containment of radioactive waste. The compilation has been synthesized primarily from published and unpublished reports and maps of the USGS (U.S. Geological Survey) and the Nevada Bureau of Mines and Geology. Additional information has been extracted from numerous scientific journals as well as several university studies.

\section{Definitions of Selected Terms}

Before proceeding to an account of the plutons found in Nevada, it is necessary to clarify several terms extensively used throughout this compilation.

Granitic Rock.--Broadly applies to any holocrystalline, quartz-bearing plutonic rock. In this report, the term is restricted to rock types ranging in composition from granite to diorite (table 1). Textural characteristics are broadly defined as equigranular and porphyritic granular. Equigranular applies to rocks whose essential mineral constituents are all of one order of size. Porphyritic granular refers to rocks in which one or more minerals are set in a finer crystalline groundmass. 
Table 1.--Generalized classification of granitic rocks

\begin{tabular}{|c|c|c|c|c|c|c|c|}
\hline \multirow{4}{*}{ Texture } & \multirow{2}{*}{\multicolumn{2}{|c|}{$\begin{array}{l}\text { Potash feldspar } \\
>2 / 3 \text { total } \\
\text { feldspars }\end{array}$}} & \multirow{2}{*}{\multicolumn{2}{|c|}{$\begin{array}{c}\text { Potash feldspar } \\
1 / 3-2 / 3 \text { total } \\
\text { feldspars }\end{array}$}} & \multicolumn{3}{|c|}{$\begin{array}{l}\text { Plagioclase feldspar } \\
>2 / 3 \text { total feldspar }\end{array}$} \\
\hline & & & & & \multirow{3}{*}{$\begin{array}{c}\begin{array}{c}\text { Potash feldspar } \\
>10 \text { percent } \\
\text { total feldspar }\end{array} \\
\text { Quartz >10 percent }\end{array}$} & \multirow{2}{*}{\multicolumn{2}{|c|}{$\begin{array}{l}\text { Potash feldspar } \\
<10 \text { percent } \\
\text { total feldspar }\end{array}$}} \\
\hline & \multirow{2}{*}{$\begin{array}{c}\text { Quartz } \\
(>10 \\
\text { percent })\end{array}$} & \multirow{2}{*}{$\begin{array}{l}\text { Quartz } \\
(<10 \\
\text { percent })\end{array}$} & \multirow{2}{*}{$\begin{array}{l}\text { Quartz } \\
(>10 \\
\text { percent })\end{array}$} & \multirow{2}{*}{$\begin{array}{c}\text { Quartz } \\
(<10 \\
\text { percent })\end{array}$} & & & \\
\hline & & & & & & Quartz $>10$ percent & Quartz $<10$ percent \\
\hline Equigranular & Granite & Syenite & $\begin{array}{l}\text { Quartz } \\
\text { monzonite }\end{array}$ & Monzonite & Granodiorite & $\begin{array}{l}\text { Quartz } \\
\text { diorite }\end{array}$ & Diorite \\
\hline $\begin{array}{l}\text { Porphyritic } \\
\text { granular }\end{array}$ & $\begin{array}{l}\text { Granite } \\
\text { porphyry }\end{array}$ & $\begin{array}{l}\text { Syenite } \\
\text { porphyry }\end{array}$ & $\begin{array}{l}\text { Quartz } \\
\text { monzonite } \\
\text { porphyry }\end{array}$ & $\begin{array}{l}\text { Monzonite } \\
\text { porphyry }\end{array}$ & $\begin{array}{l}\text { Granodiorite } \\
\text { porphyry }\end{array}$ & $\begin{array}{l}\text { Quartz } \\
\text { diorite } \\
\text { porphyry }\end{array}$ & $\begin{array}{l}\text { Diorite } \\
\text { porphyry }\end{array}$ \\
\hline
\end{tabular}


Pluton.--Generally implies a body of igneous rock that has formed beneath the surface of the Earth by consolidation of magma. In this report, the term denotes a single or group of exposures, and has been broadly used to conveniently group outcrops rather than to imply any genetic relationship. In certain cases the terms "stock" and "batholith" have been substituted for pluton. Herein, "stock" refers to igneous intrusions less than $100 \mathrm{~km}^{2}$ in surface exposure, and may or may not imply a discordant relationship with the surrounding country rock. "Batholith" denotes a plutonic mass more than $100 \mathrm{~km}^{2}$ in surface area.

Aeromagnetic Anomalies.--The terms "positive" and "negative anomalies" as used in this report are relative terms, "positive" referring to features having higher amplitudes than immediately surrounding anomaly values, and "negative" referring to features having lower amplitudes than immediately surrounding values. The expressions "high" and "low" amplitudes are also subjective terms; "high" referring to an amplitude of at 1east 100 gammas ( 1 gamma equals about one fifty-thousandth of the Earth's magnetic field strength at the surface of the Earth), and "low" referring to an amplitude of less than 100 gammas. The significance of the magnitude of the anomaly amplitude may be judged only by taking into account the flight elevation of the magnetometer-carrying aircraft.

The "source" of an anomaly refers to the magnetized rocks that cause the anomaly--the magnetization of the rocks being attributable to magnetite or a related magnetic mineral species. In general, more highly mafic rocks, such as basalt or diorite, have stronger magnetizations than more highly felsic ones, such as rhyolite or granite, largely because of greater abundances of magnetic mineral grains.

The "trend," "gradient," and "wavelength" of an anomaly refer, respectively, to the azimuthal orientation of its axis, the amount of change of amplitude per unit of horizontal distance across the entire anomaly (mathematically, this is actually about one-half the full wavelength), and the distance between successive similar points across the crest of the anomaly.

\section{Method of Study}

\section{General Statement}

This inventory of 200 exposed granitic masses was compiled on a county-by-county basis (fig. 1), with two exceptions. Nye County has been divided into northern Nye and southern Nye, whereas, Washoe, Storey, and Douglas Counties and Carson City (independent city) have been combined and discussed under one section. Each county compilation begins with an introduction that briefly describes the regional geologic and hydrologic setting and the major references used. Each county introduction is followed by county maps (figs. 4-18) that indicate the 10cations and distribution of plutons within each county. Also included are major towns, roadways, and railways. The summary basically is divided into two groups of factors. The first group deals with geographic factors, including (1) general location, (2) coordinates, (3) land classification, (4) accessibility, and (5) remoteness. The second group includes technical parameters such as (1) geologic setting, (2) hydrologic setting, (3) aeromagnetic expression, (4) mining activity, and (5) general comments. It should be nnted that not all technical factors that may be pertinent to storage of radioactive wastes have been included. Such factors as geomorphology of the area, volcanic history, location and extent of abandoned underground workings, potential ore reserves, and detailed subsurface configurations have not been considered in this preliminary assessment. 


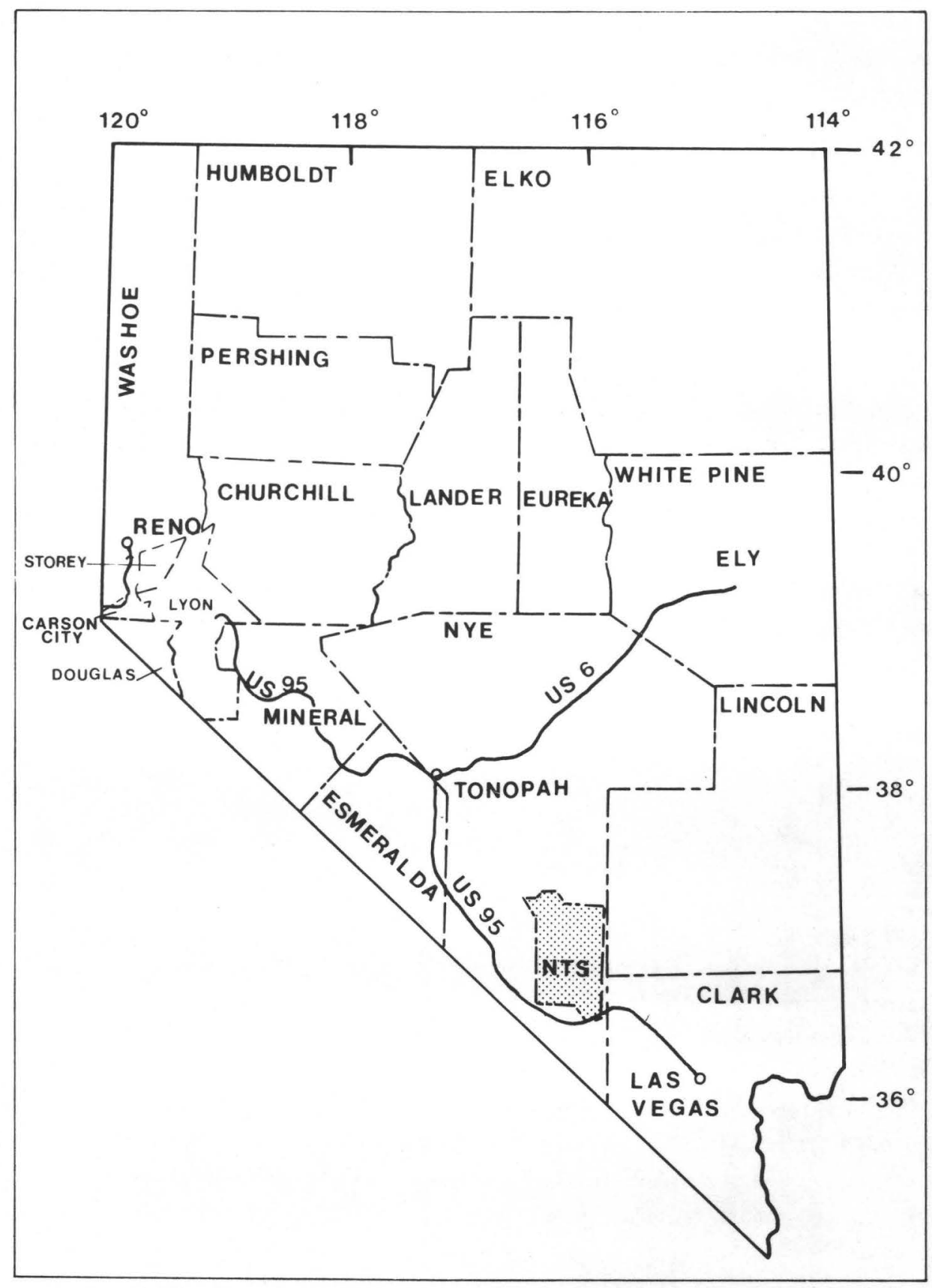

Figure 1.--Index map of Nevada showing location of counties and the Nevada Test Site. 
The following nine plates are provided to augment data supplied in the text:

Plate 1.--Map of State of Nevada (topographic base map, 1965 edition).

2.--Generalized land-classification map of Nevada.

3A.--Generalized hydrology of Nevada and other parts of the Great Basin (showing areas of ground-water discharge, Pleistocene lakes and direction of groundwater movement).

3B.--Generalized hydrology of Nevada and other parts of the Great Basin (showing ground-water discharge and major sources of recharge and runoff).

4.--Generalized tectonic map of Nevada and parts of California.

5.--Preliminary location of epicenters in the State of Nevada and parts of California.

6A.--Aeromagnetic map of Nevada (published mosaic of numerous surveys flown at various altitudes).

6B.--Composite Aeromagnetic map of Nevada (unpublished map using data recalculated to $3,810 \mathrm{~m}(12,500 \mathrm{ft})$ above sea 1eve1).

7.--Distribution of granitic rocks in Nevada.

\section{Explanation of Factors}

The following is a description of the general information provided and the primary sources of data for each of the factors listed for each pluton.

Designation of Plutons.--Individual exposures or groups of exposures have been assigned a name, prefix, and number to facilitate easy reference to plates, county figures, and discussions. Names of plutons have been extracted from the literature, where available. Granitic rock exposures not previously named were assigned names of topographic features occurring on or near the plutons. These topographic features include mountain ranges, mountain peaks, hills, canyons, valleys, and creeks. Some plutons were assigned the names of local mining districts. The prefix signifies the county in which the pluton occurs and the number represents the order of discussion for each pluton within a particular county. The prefix designations for each county are as follows:

$$
\begin{aligned}
& \text { CL--Clark } \\
& \text { LI--Lincoln } \\
& \text { SN--Nye (southern part) } \\
& \text { NN--Nye (northern part) } \\
& \text { ES--Esmeralda } \\
& \text { M--Mineral } \\
& \text { L--Lyon } \\
& \text { CH--Churchill } \\
& \text { LA--Lander }
\end{aligned}
$$$$
\text { EU--Eureka }
$$$$
\text { WP--White Pine }
$$$$
\text { EL--Elko }
$$$$
\text { H--Humboldt }
$$$$
\text { P--Pershing }
$$$$
\text { WS--Washoe }
$$$$
\text { *--Carson City (independent city) }
$$$$
\text { S--Storey }
$$$$
\text { D--Douglas }
$$

*Outcrops occurring in Carson City (independent city) are included in Washoe and Douglas Counties. 
General Location.--A generalized location of each pluton included, giving reference to a particular topographic, hydrographic, or cultural feature. Topographic features generally are mountain ranges, hills, and valleys (pl. 1). Hydrographic features are major streams or lakes, and cultural features generally are nearby towns.

Coordinates.--Latitude and longitude of the approximate center of each pluton have been recorded in degrees and minutes. Measurements were made from map scales of 1:500,000 and $1: 250,000$. Where a pluton is represented by a cluster of outcrops, the coordinates were measured from a central point within the largest outcrop, or from a point centrally located within the group.

Land Classification.--Classification of land refers to either private ownership or to the administration of lands under Federal jurisdiction. Information was obtained and, in some cases, generalized from Lutsey and Nichols, 1972.

Area.-- Exposed areas of granitic rock were measured using a compensating polar planimeter and are expressed in square kilometers. Approximate surface configurations were obtained from county geologic maps $(1: 250,000)$ and Stewart and Carlson (1978). Where a pluton is represented by several isolated exposures, the cumulative area of all exposures is recorded.

Accessibility.--Data given in this section were interpreted principally from U.S. Army Map Service topographic sheets $(1: 250,000)$, USGS topographic map series, and USGS State of Nevada map $(1965,1: 500,000)$. Data provide approximate distances to improved roads such as major State, U.S., and Interstate Highways, and railroads. Unimproved roads commoniy extend to areas of interest but are only mentioned if major roadways are at considerable distances from plutons. Major roadways and railways are also plotted on county maps.

Remoteness.--Approximate distances to centers of population are documented within this section. Distances were derived from U.S. Army Map Service $1^{\circ} \times 2^{\circ}$ sheets, USGS topographic map series, and USGS State of Nevada map $(1965,1 .: 500,000)$. Populations, where available, are also included and were obtained from Rand McNally (1977).

Geologic setting.--This section includes geologic information pertaining to the consistency, uniformity, and homogeneity of each pluton as well as the nature of overlying and flanking geologic formations. We emphasized that most geologic studies in Nevada have been of a reconnaissance nature and detailed descriptions of plutons are seldom available. Many of the granitic masses have been classified by field inspection only and have not been confirmed by geochemical or petrographic analyses. Where information is available, specific data extracted from the literature include the following.

1. Major type and age of granitic rock.

2. Presence and nature of lithologic variations, such as roof pendants, xenoliths, facies changes, multiple intrusions, and zones of alteration.

3. Nature and extent of major structural discontinuities, such as faults, igneous contacts, dikes, and sills.

4. Major and minor rock types and formations that have been intruded by and overlie the mass and their ages (table 2). 
Table 2.--Major stratigraphic and time divisions used in this report

\begin{tabular}{|c|c|c|c|}
\hline $\begin{array}{l}\text { Era or } \\
\text { Erathem }\end{array}$ & System or Period & Series or Epoch & $\begin{array}{l}\text { Age estimates } \\
\text { commonly used for } \\
\text { boundaries (in } \\
\text { millions of years) }\end{array}$ \\
\hline \multirow{7}{*}{ Cenozoic } & \multirow{2}{*}{ Quaternary } & Holocene & \multirow[b]{2}{*}{$-1.5-2-$} \\
\hline & & Pleistocene & \\
\hline & \multirow{5}{*}{ Tertiary } & Pliocene & \multirow{2}{*}{$\begin{array}{r}1.5-2- \\
-\quad \text { ca. } 7 \\
-26\end{array}$} \\
\hline & & Miocene & \\
\hline & & Oligocene & \multirow{2}{*}{$\begin{array}{r}37-38 \\
-\quad 53-54\end{array}$} \\
\hline & & Eocene & \\
\hline & & Paleocene & \\
\hline \multirow{3}{*}{ Mesozoic } & Cretaceous & $\begin{array}{l}\text { Upper (Late) } \\
\text { Lower (Early) }\end{array}$ & \\
\hline & Jurassic & $\begin{array}{l}\text { Upper (Late) } \\
\text { Middle (Middle) } \\
\text { Lower (Early) }\end{array}$ & -136 \\
\hline & Triassic & $\begin{array}{l}\text { Upper (Late) } \\
\text { Middle (Middle) } \\
\text { Lower (Early) }\end{array}$ & \\
\hline \multirow{7}{*}{ Paleozoic } & Permian & $\begin{array}{l}\text { Upper (Late) } \\
\text { Lower (Early) }\end{array}$ & \multirow{4}{*}{$\begin{array}{l}-280- \\
-320- \\
-\end{array} 345-$} \\
\hline & Pennsylvanian & $\begin{array}{l}\text { Upper (Late) } \\
\text { Middle (Middle) } \\
\text { Lower (Early) }\end{array}$ & \\
\hline & Mississippian & $\begin{array}{l}\text { Upper (Late) } \\
\text { Lower (Early) }\end{array}$ & \\
\hline & Devonian & $\begin{array}{l}\text { Upper (Late) } \\
\text { Middle (Middle) } \\
\text { Lower (Early) }\end{array}$ & \\
\hline & Silurian & $\begin{array}{l}\text { Upper (Late) } \\
\text { Middle (Middle) } \\
\text { Lower (Early) }\end{array}$ & $-430-440-$ \\
\hline & Ordovician & $\begin{array}{l}\text { Upper (Late) } \\
\text { Middle (Middle) } \\
\text { Lower (Early) }\end{array}$ & $-430-440-$ \\
\hline & Cambrian & $\begin{array}{l}\text { Upper (Late) } \\
\text { Middle (Middle) } \\
\text { Lower (Early) }\end{array}$ & $-570-$ \\
\hline Precambrian & \multicolumn{2}{|c|}{$\begin{array}{l}\text { Precambrian Z--base of Cambrian to } 800 \mathrm{~m} \cdot \mathrm{y} \text {. } \\
\text { Precambrian } \mathrm{Y}--800 \mathrm{~m} \cdot \mathrm{y} \text { : to } 1,600 \mathrm{~m} \cdot \mathrm{y} \text {. } \\
\text { Precambrian } \mathrm{X}-\mathrm{-1}, 600 \mathrm{~m} \cdot \mathrm{y} \text {. to } 2,500 \mathrm{~m} \cdot \mathrm{y} \text {. } \\
\text { Archean--older than } 2,500 \mathrm{~m} \cdot \mathrm{y} \text {. }\end{array}$} & \\
\hline
\end{tabular}


Hydrologic Setting.--Basic data presented in this section pertain to an initial hydrologic appraisal of areas adjacent to granitic masses. Existing hydrologic data were principally derived from 60 reconnaissance-series reports on valleys in Nevada, prepared by personnel of the USGS. These data were augmented by several USGS Water-Supply Papers and Professional Papers, and by Nevada Water-Resources Bulletins. Data include:

1. general ground-water system and drainage basins,

2. nearest significant ground-water discharge area, stream, or lake within its respective ground-water system, measured from a central point within the pluton, and

3. primary use of water in that area.

Aeromagnetic Expression.--In this section, brief descriptions of aeromagnetic expressions associated with each pluton are given. Data have becin interpreted from the compilation of Zietz, Stewart, Gilbert, and Kirby (1977 and p1. 6A), where most of the individual areas were surveyed at a barometric elevation of 2,743 $\mathrm{m}(9,000 \mathrm{ft})$, although other surveys range from 152 to $3,810 \mathrm{~m}(500-12,500 \mathrm{ft})$. (Note: This section presents both metric and English units in order to discuss aeromagnetic data compiled in English units.)

As examples of magnetic features that might be observed over plutonic rock bodies, the anomalies associated with several simple prismatic models are shown on figures 2 and 3 . The distance from the elevation of the survey to the top of the anomaly source is taken to be $1.5 \mathrm{~km}$, which is representative of, for example, (1) a 3,810-m (12,500-ft) survey over exposed plutonic rocks at a 2,286-m $(7,500-\mathrm{ft})$ elevation (2) a 2,743-m (9,000-ft) survey over plutonic rocks buried $457 \mathrm{~m}(1,500 \mathrm{ft})$ below a ground surface of 1,676-m $(5,500-\mathrm{ft})$ elevation, or (3) a survey $152 \mathrm{~m}(500 \mathrm{ft})$ above ground underlain by plutonic rocks at a depth of 1,372 $\mathrm{m}(4,500 \mathrm{ft})$. The 3,810-,2,743-, and 152-m (12,500-, 9,000-, and 500-ft) elevations of surveys are typical of those represented on the compilation of Zietz, Stewart, Gilbert, and Kirby (1977 and pl. 6N), and the topographic elevations of 2,286 and 1,674 m (7,500 and 5,500 ft) are typical of those corresponding to areas of plutonic rocks in Nevada. The areal extent of the top of each model is $54 \mathrm{~km}^{2}$.

The amplitudes of the anomalies of the models depend mainly on the thickness of the body-an expression of the volume of magnetic material--and on the magnitude and direction of the total magnetization. On figure 2, the body thickness is varied by a factor of 10 , resulting in a change in amplitude anomaly by a factor of $71 / 2$. A total magnetization magnitude of $10^{-3} \mathrm{Cgs} / \mathrm{cm}^{3}$ (centimeters-gram-second/cubic centimeters) was taken for all models on figures 2 and 3, based on results of Bath (1976) for Cretaceous and Tertiary intrusive rocks. On figure 3, four examples of anomalous total magnetization are shown, representing different directions of total magnetization. It may be noted that, just as for anomalies shown as b, $c$, and $d$ on figure 1, anomalies $c$ and $d$ of figure 2 serve as reliable indicators of the location and areal extent of the top of the prismatic model. Anomalies associated with sources having low magnetization inclinations are of highly limited use in assessing the tops of prismatic sources.

A11 comments throughout the remainder of the report relating to aeromagnetic expression refer to observations of the compilation of Zietz, Stewart, Gilbert, and Kirby (1977). A1though, a constant-level $3,810 \mathrm{~m}(12,500 \mathrm{ft})$ composite aeromagnetic map recalculated from various flight altitudes is also included ( $11.6 \mathrm{~B})$. 


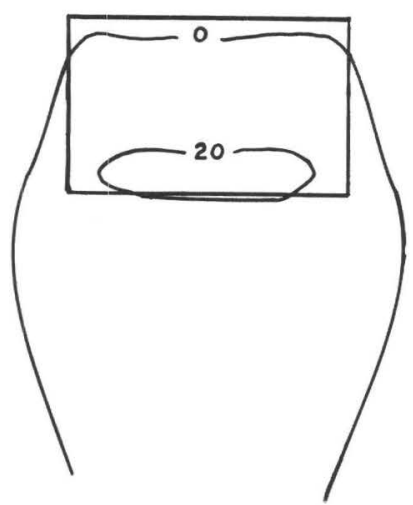

Thickness-150 m

(a)

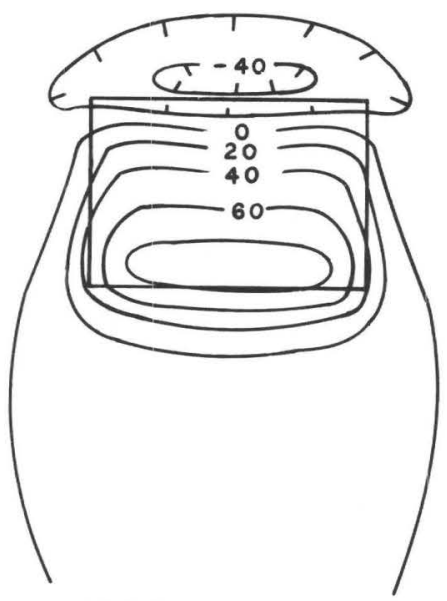

Thickness $=750 \mathrm{~m}$

(c)

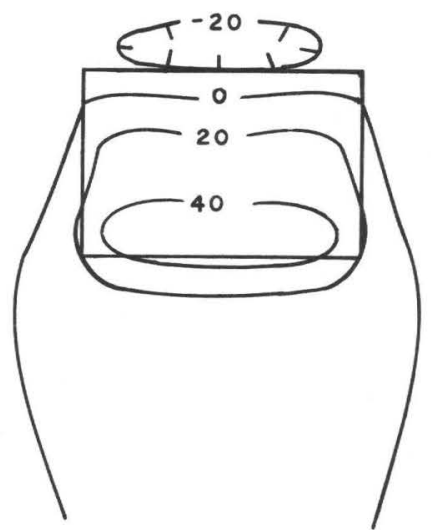

Thickness $=375 \mathrm{~m}$

(b)

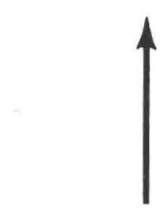

MAGNETIC

NORTH

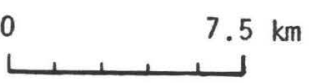

Thickness $=1,500 \mathrm{~m}$

(d)

Distance from survey elevation to top of model $=1,500 \mathrm{~m}$.

Total magnetization is $10^{-3} \mathrm{Cgs} / \mathrm{cm}^{3}$, parailel to Earth's magnetic field.

Contour interval: 20 gammas.

Area of top of model $=9 \mathrm{~km} \times 6 \mathrm{~km}=54 \mathrm{~km}^{2}$.

Figure 2.--Plan of total-intensity magnetic anomalies associated with rectangular prismatic models having various thicknesses. Magnetic field inclination $=60^{\circ}$. As the thickness of this model increases to a geologically reasonable maximum of about $20 \mathrm{~km}$, the maximum amplitude increases only to about 350 gammas. 


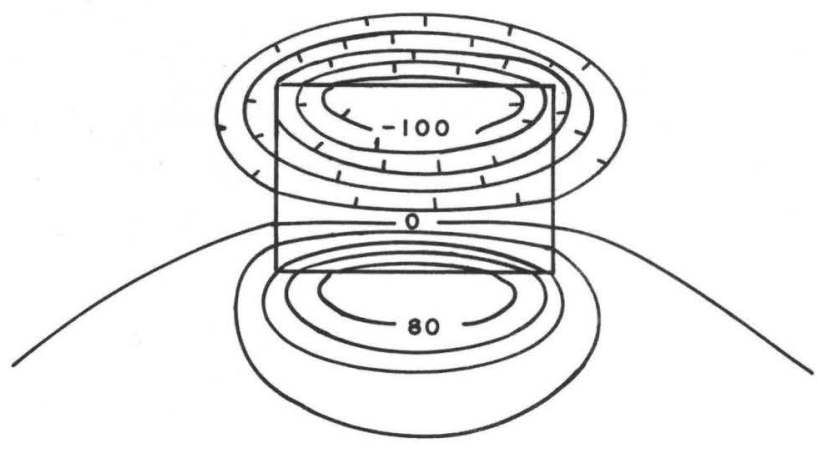

Magnetization direction: $\mathrm{D}=0^{\circ}, \mathrm{I}=0^{\circ}$

(a)

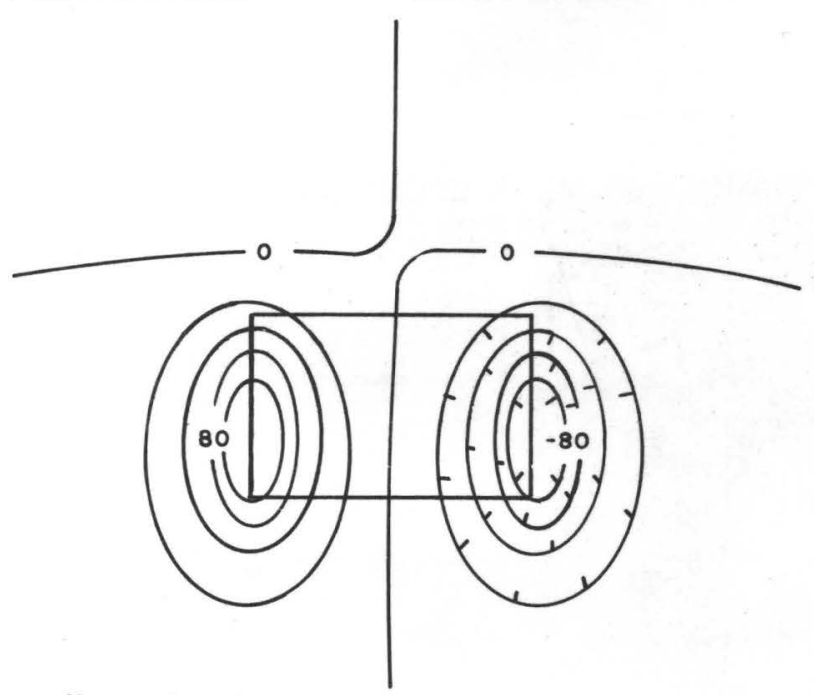

Magnetization direction: $D=90^{\circ} \mathrm{E} ., \mathrm{I}=0^{\circ}$

(b)
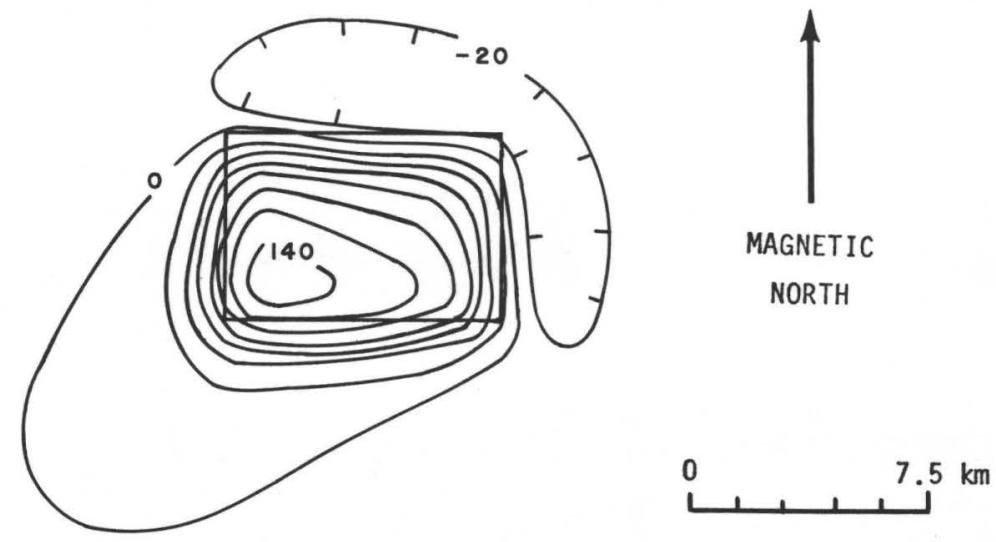

Magnetization direction: $D=90^{\circ} \mathrm{E}, \mathrm{I}=60^{\circ}$

(c)

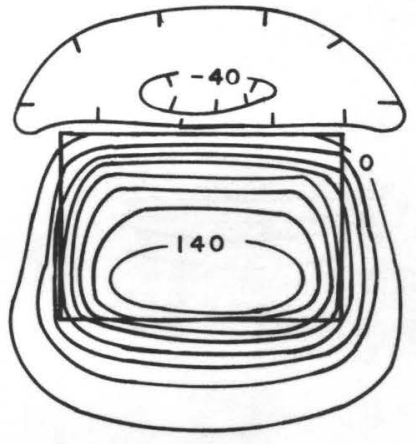

Magnetization direction: Vertical

(d)

Distance from survey elevation to top of model-1,500 m.

Total magnetization is $10^{-3} \mathrm{Cgs} / \mathrm{cm}^{3}$.

Contour interval: 20 gammas.

Thickness of models $=1,500 \mathrm{~m}$.

Area of top of model $=9 \mathrm{~km} \times 6 \mathrm{~km}=54 \mathrm{~km}^{2}$.

Figure 3.--Plan of total-intensity magnetic anomalies associated with rectangular prismatic models having various directions of total magnetization ( $D=d e c l i n a-$ tion, I=inclination). Magnetic field inclination $=60^{\circ}$. Note that the anomalies of models having steeply dipping, though anomalous magnetization (c and d) are useful indicators of the areal extent and location of the top of the model. Modified after Andreasen and Zietz (1969). 
Mining Activities.--Data provided in this section denote area near plutons where mining and drilling operations were in progress as late as 1976 and name the major reserves being developed. In certain instances comments have been made regarding historical mining activities (1900-1976) for selected plutons. General areas of local mining have been extracted from Payne and Papke (1977).

Comments.--This section has been reserved for remarks pertaining to any geologic or hydrologic consideration that may play a role in the initial assessment of potential areas for containment of radioactive wastes. Considerations include areas of active erosion, areas where hot springs occur, zones of high seismic activity, recent faulting, prominent fault zones, and areas where prominent lakes, reservoirs, and streams occur.

Selected References.--Although the major sources of information for counties are listed within the introduction to each county, this section gives one or more selected references that provide specific information concerning a particular pluton. It should be noted that time did not permit an exhaustive survey of all available literature.

\section{Acknowledgments}

This report involved compilation of data from several Earth-science disciplines. Geographic and geologic data for Clark, northern Nye, Mineral, Eureka, Churchi11, Elko, Washoe, Storey, and Douglas Counties and Carson City were compiled by Richard W. Spengler. Florian Maldonado compiled geographic and geologic information for Lincoln, Esmeralda, Lyon, White Pine, Lander, Pershing, Humboldt, and southern Nye Counties.

Sections on hydrology were compiled by J. E. Weir, Jr., and W. F. Hanna contributed sections on aeromagnetic expression.

Critical and helpful reviews of the report were provided by $H$. W. Smedes and F. E. Rush. 
Clark County is situated in the extreme southern tip of Nevada, bounded on the southeast by the Colorado River which forms a natural boundary between Nevada and Arizona. The southwestern edge of the county forms part of Nevada-California State line (fig. 4).

Exposed plutons found within Clark County range in composition from granite to diorite and range in age from Precambrian to Tertiary. All of the intrusions occupy areas south and east of Las Vegas and extend southward to the southern tip of Nevada. Most of the igneous masses either lie adjacent to Lake Mead or to the Colorado River.

Eastern Clark County differs geologically from other counties within Nevada by having extensive exposures of Precambrian rocks. These rocks consist mainly of schist, gneiss, and granite that crop out in the Virgin Mountains east of Las Vegas and west of the Colorado River. The Precambrian granites are generally coarse grained, brecciated, and commonly form networks of dikes and stringers that intricately penetrate the metamorphic rocks.

Extensive exposures of granitic rocks occur within a north-trending granitic complex that underlies the Eldorado and Newberry Mountains, directly south of Boulder City. These granitic masses represent several intrusions in which a central core of Jurassic and Tertiary granites was mapped as being discontinuously encased within an envelope of Precambrian gneisses, schists, and granites. These rocks not only exhibit a wide variation in mineralogical compositions but also vary considerably in textural fabric. At many localities dikes of several compositions and textures, including aplites, pegmatites, and hornblendites, cut both the metamorphic and granitic rocks.

\section{HYDROLOGY}

Most of Clark County is in the Colorado River drainage basin; the western and southwestern parts of the county drain centripetally to playas. Piute Valley drains into the Colorado River to the south in California.

The Spring Mountains and Sheep Range are the major sources of recharge and runoff in Clark County. A large proportion of these recharge sources feeds into Ash Meadows and Pahrump Valley ground-water systems, mainly in adjacent counties to the west and northwest; but some of this water recharges the Las Vegas Valley ground-water system.

The northwest part of the county is underlain by the Ash Meadows ground-water system that features flow westward to the Amargosa Desert and, ultimately, to Death Valley. The Pahrump Valiey ground-water system, partly in California and Nye County, Nev. occupies the southwest part of the county. The Pahrump Valley system is thought to be open hydrologically, with some ground-water flow to adjacent valleys to the southwest.

The central and southern parts of the county are in the Las Vegas ground-water system that features eastward flow to the Colorado River at Lake Mead. The south-moving White River groundwater system terminates in the northeast part of the county, where its ground water is discharged into the Muddy River.

Many wells are pumped to furnish a part of the municipal water supply for Las Vegas and the surrounding metropolitan area. Additional large-capacity wells are used for irrigation, and public and domestic supplies within the populated part of Las Vegas Valley.

The hydrology of Clark County was taken mainly from the following references: Glancy, 1968a; Malmberg, 1965, 1967; Rush, 1968a, 1970; and Rush and Huxe1, 1966. 


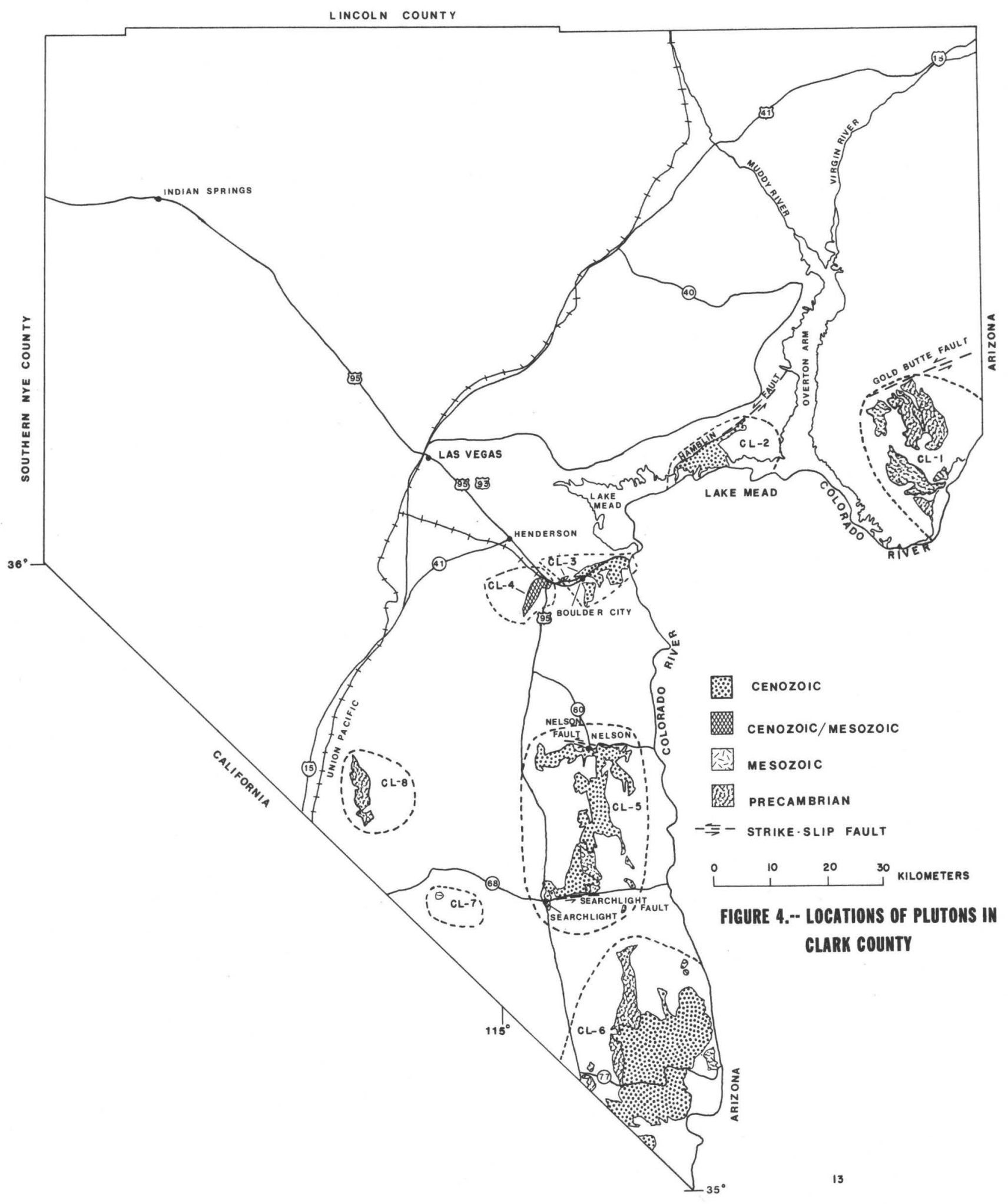




\section{CL-1. GOLD BUTTE DISTRICT}

General location: Southern end of the South Virgin Mountains, directly east of the mouth of the Overton Arm of Lake Mead.

Coordinates: lat $36^{\circ} 12^{\prime} \mathrm{N}$. , long $114^{\circ} 11^{\prime} \mathrm{W}$.

Land classification: The southern half of the area lies within the Lake Mead recreation area,

Area: $120 \mathrm{~km}^{2}$. and the northern half is designated as public domain.

Accessibility: Access to the area is limited to jeep trails extending northward and crossing over the Colorado River near Riverside, approximately $51 \mathrm{~km}$ north of the exposures.

Remoteness: The nearest populated area is Boulder City (population 5,223), $56 \mathrm{~km}$ southwest of the outcrops.

Geologic setting: The Precambrian complex of the Gold Butte area generally consists of porphyritic granites and quartz monzonites that intrude Precambrian gneisses, migmatites, older granites, pyroxenites, and hornblendites. The exposure represents the roof portion of a batholith, with numerous cupolas, dikes, inclusions, and intrusion breccias. Rb-Sr ages have been determined from potassium feldspar in two samples of granite. The ages are $1.06 \times 10^{9}$ and $1.09 \times 10^{9}$ years (Volborth, 1962).

Although the complex is largely covered by alluvium along the margins, the eastern border of surrounding metamorphic rocks is overlain nonconformably by a sequence of Paleozoic quartzites, shales, dolomites, and limestones, locally mineralized. This same sedimentary sequence also occurs directly north of the exposures as a result of left-lateral movement along the Gold Butte strike-slip fault.

The Precambrian granites commonly are coarse grained, brecciated, and generally form networks of dikes that penetrate the metamorphic rocks. Hydrologic setting: The district is in the Lake Mead ground-water system and the Colorado River drainage basin. The ground-water discharge nearest the center of the exposures is $7 \mathrm{~km}$ southwest into Lake Mead; southern outcrops are at the Lake Mead shoreline. Water of the lake is used for public supply, recreation, irrigation, and hydroelectric power.

Aeromagnetic expression: A broad, high-amplitude positive anomaly is associated with the mapped rocks. The northward displacement of the anomaly maximum appears to be related to topography. Similar rocks may occur at depth approximately $25 \mathrm{~km}$ to the north. The maximum areal extent of the inferred anomaly source is estimated to be about the same as the area of mapped rocks.

Mining activity: Gold and silver are actively being mined at two localities within the complex. Reference: Volborth, 1962. 


\section{CL-2. WILSON RIDGE}

General location: North of Boulder Canyon in the northern Black Mountains.

Coordinates: lat $36^{\circ} 10^{\prime} \mathrm{N}$, , long $114^{\circ} 35^{\prime} \mathrm{W}$.

Land classification: Lake Mead recreation area.

Area: $33 \mathrm{~km}^{2}$.

Accessibility: A secondary, all-weather road extends east of Las Vegas and flanks the northern edge of Lake Mead, approximately $2 \mathrm{~km}$ north of the exposure.

Remoteness: Area lies approximately $46 \mathrm{~km}$ east of Las Vegas (population 125,787) and $29 \mathrm{~km}$ northeast of Boulder City (population 5,223).

Geologic setting: The Wilson Ridge pluton is a highly complex composite mass that consists of numerous dikelike bodies ranging from rhyolite to basalt and from porphyritic granite to porphyritic diorite (Anderson, 1973).

The intrusive is part of the northern extremity of the Black Mountain structural block. The Boulder Wash Fault marks the eastern boundary, whereas the oblique-slip and left-lateral Hamblin Bay Fault Zone represents the northern and western boundaries. Abundant structural discontinuities marking different intrusive contacts or fault contacts have been mapped within the pluton (Anderson, 1973).

Hydrologic setting: The pluton is in the Lake Mead ground-water system and Colorado River drainage basin. The center of the pluton is in the ground-water discharge area and the water of Lake Mead is used for public supply, recreation, irrigation, and hydroelectric power.

Aeromagnetic expression: A northeast-trending positive anomaly at this site appears to be mainly associated with exposures of basalt and related extrusive rocks.

Comment: The southern border of the area forms part of the northern shoreline of Lake Mead. Selected reference: Anderson, 1973. 


\section{CL-3. BOULDER CITY}

General location: Underlies Boulder City.

Coordinates: lat $35^{\circ} 59^{\prime} \mathrm{N}$., long $114^{\circ} 49^{\prime} \mathrm{W}$.

Land classification: Private land within the city limits of Boulder City.

Area: $34 \mathrm{~km}^{2}$.

Accessibility: U.S. Highway 93 passes over the exposure.

Remoteness: Boulder City (population 5,223) overlies the pluton.

Geologic setting: The Boulder City pluton is a composite Tertiary intrusive ranging in composition from granodiorite to granite. The pluton intrudes Patsy Mine

Volcanics. Both the pluton and the volcanics are highly faulted and brecciated, especially along the eastern border of the exposed pluton.

The age of a sample of monzonite, dated by lead-alpha methods, was 53^10 m.y. (Schilling, 1965).

Hydrologic setting: The pluton is in the Colorado Valley ground-water system. Runoff drains to the Colorado River and Eldorado Valley drainage basins. The nearest discharge occurs $2.5 \mathrm{~km}$ east into the Colorado River. Water of the river is used for public supply, hydroelectric power, and irrigation farther downstream.

Aeromagnetic expression: The mapped rocks occur at the southern flank of a broad low-amplitude negative anomaly and do not appear to be a significant anomaly source.

Comment: The Colorado River passes within $3 \mathrm{~km}$ of the pluton.

Selected references: Anderson, 1969; Schilling 1965. 
General location: Northeastern extremity of the McCullough Range at Railroad Pass.

Coordinates: lat $35^{\circ} 58^{\prime} \mathrm{N}$., long $114^{\circ} 56^{\prime} \mathrm{W}$.

Land classification: Public domain.

Area: $13 \mathrm{~km}^{2}$.

Accessibility: U.S. Highways 95 and 93 pass about $0.5 \mathrm{~km}$ north of the exposure. A branch of the Union Pacific Railroad parallels the highways.

Remoteness: Boulder City (population 5,223) lies $8 \mathrm{~km}$ east and Henderson (population 16,395)

lies $8 \mathrm{~km}$ northwest of the exposure.

Geologic setting: Longwel1, Pampeyan, Bowyer, and Roberts (1965) mapped the intrusive as undivided porphyritic rocks, which include granite porphyry, rhyolite, and trachydolerite of Cretaceous(?) and Tertiary age.

The intrusive is overlain by alluvium along the east and Tertiary volcanics along the western and southern borders.

Hydrologic setting: The pluton is in the Eldorado Valley ground-water system and drainage basin. The nearest discharge point is $13 \mathrm{~km}$ east into the Colorado River. Water of the river is used for public supply, hydroelectric power, and irrigation farther downstream.

Aeromagnetic expression: The mapped rocks occur on the common flank of positive and negative anomalies and do not appear to be a significant anomaly source.

Mining activity: The area lies within the Alunite (Railroad Pass) district, which was mined for gold and alunite in the early 1900's, but operations ceased in the late 1930's.

Selected reference: Longwe11, Pampeyan, Bowyer, and Roberts, 1965. 
General location: Southern Eldorado Mountains, south of Nelson and north of Searchlight. Coordinates: lat $35^{\circ} 36^{\prime} \mathrm{N}$., long $114^{\circ} 49^{\prime} \mathrm{W}$. (central part of exposure).

Land classification: The eastern part lies within the Lake Mead recreation area and the western half is designated as public domain, except for local patented mining claims near the towns of Nelson and Searchlight.

Area: The Tertiary and Precambrian granites encompass areas of 150 and $18 \mathrm{~km}^{2}$, respectively. Accessibility: U.S. Highway 95 traverses southward from Railroad Pass and passes within $8 \mathrm{~km}$ of the outcrops. Access to the northernmost exposures is by way

of State Highway 60 , which intersects U.S. Highway 95 at Searchlight playa and extends eastward to Lake Mohave.

Remoteness: The towns of Nelson (population 60) and Searchlight (population 200) border the northern and southern exposures, respectively.

Geologic setting: The southern Eldorado Mountains are a northern exposed segment of a northtrending complex of igneous and metamorphic rocks of Precambrian and Tertiary age. It has been postulated that the complex has undergone at least three major orogenic events subsequent to the Paleozoic Era (Volborth, 1973). The latest event probably extended into the early Pliocene Epoch and resulted in the emplacement of granite, now forming the central core of the complex. Potassium-argon age of a sample of granite from the knob Hill pluton is $26(+4,-2)$ m.y. (Schilling, 1965). The age of quartz monzonite near Searchlight was determined to be $14.0-0.5$ m.y. (Krueger and Schilling, 1971). Metamorphosed Precambrian gneisses, schists, and granites form a discontinuous jacket around the exposed pluton; these rocks may represent the central roof portion of a larger granitic core. At several places the complex is overlain by klippen of megabreccia composed of mixtures of Precambrian granites and rhyolitic and andesitic blocks, which are probably associated with past events of thrust faulting.

Two major structural features are the east-trending Nelson and Searchlight Faults, which mark the northern and southern borders of the exposed batholith.

Numerous swarms of felsic and mafic dikes cut the granitic body along northtrending axial zones of weakness that are associated with an anticlinal structure.

Hydrologic setting: The pluton is in the Colorado Valley ground-water system and runoff drains to the Colorado River and to Eldorado Valley. The nearest discharge is $8 \mathrm{~km}$ east into the Colorado River. Water of the river is used for public supply, hydroelectric power, and irrigation farther downstream.

Aeromagnetic expression: A northwest-trending, high-amplitude positive anomaly is associated with the mapped complex of rocks. The maximum areal extent of the inferred anomaly source is estimated to be about the same as the mapped complex of rocks. 
CL-5 KNOB HILL--Continued

Mining activity: One gold and silver mine is currently (1976) in operation along the Nelson Fault Zone, west of the town of Nelson. Areas around Searchlight have been extensively mined but are currently inactive.

Comment: Geomorphic features noted by Volborth (1973) suggest rapid and extensive erosion along the eastern flank of the Eldorado Mountains owing to the action of the Colorado River.

Selected references: Krueger and Schilling, 1971; Schilling, 1965; and Volborth, 1973. 
CL-6. SPIRIT MOUNTAIN

General location: The Spirit Mountain pluton underlies the Newberry Mountains located near the southern tip of Nevada.

Coordinates: lat $35^{\circ} 13^{\prime} \mathrm{N}$., long $114^{\circ} 42^{\prime} \mathrm{W}$.

Land classification: The eastern half lies within the Lake Mead recreation area and the western part is designated as public domain.

Area: $345 \mathrm{~km}^{2}$.

Accessibility: U.S. Highway 95 extends southward from Searchlight within a few meters of the westernmost exposures. Access to the central and eastern parts of the granitic mass can be made along State Highway 77 , which traverses the range and crosses the Colorado River at Davis Dam.

Remoteness: Northern limits of the Precambrian granites are within $16 \mathrm{~km}$ of Searchlight (population 200) and the southern part of Tertiary granites is within $6 \mathrm{~km}$ and $3 \mathrm{~km}$ of Bullhead City and Riviera, Ariz., respectively.

Geologic setting: The most prevalent rock type underlying the Newberry Mountains is Tertiary granite. It is quite variable in composition and includes microgranite, rapakivi granite, and muscovite granite. The central part of the mass is characterized by numerous rhyolite and diabase dikes that penetrate the granite along axial zones of weakness. Precambrian granites and metamorphic rocks form a discontinuous envelope around the exposed core of Tertiary granites. Isolated exposures of Precambrian granites found within the alluvial fill have been inferred to represent slide blocks detached from the main body. Contacts between the Tertiary and Precambrian exposures commonly are faults. Rhyolite, diabase, pegmatite, and aplite dikes are pervasive throughout the Precambrian rocks.

Hydrologic setting: The pluton is in the Colorado Valley ground-water system and the

Colorado River drainage basin. The nearest discharge is $6 \mathrm{~km}$ east

into the Colorado River. Water of the river is used for public supply, hydroelectric power, and irrigation farther downstream.

Aeromagnetic expression: No well-defined, regional anomaly is associated with the mapped rocks. A north-trending low-amplitude positive anomaly centered over the southern part of the mapped rocks has an unknown source but may in part be caused by the rocks. A high-amplitude positive anomaly at the northern extremity of the mapped rocks appears to be associated with andesitic and basaltic extrusive rocks.

Mining activity: Lead and silver deposits are currently (1976) being mined along the western flank of the Newberry Mountains.

Comment: The northeastern segment of the exposed batholith forms part of the Colorado River shoreline, and the eastern flank is characterized by extensive and rapid erosion. Selected reference: Volborth, 1973. 


\section{CL-7. CRESCENT PEAK}

General location: Northern part of the New York Mountains, west of Searchlight.

Coordinates: lat $35^{\circ} 28^{\prime} \mathrm{N}$., long $115^{\circ} 07^{\prime} \mathrm{W}$.

Land classification: The southern part of the exposure consists mainly of patented mining claims, and the remainder is public domain.

Area: $1.6 \mathrm{~km}^{2}$.

Accessibility: State Highway 68 passes along the northern end of the New York Mountains

within $3 \mathrm{~km}$ of the exposure. The Union Pacific Railroad passes within

$13 \mathrm{~km}$ of the outcrop.

Remoteness: Searchlight is $19 \mathrm{~km}$ east of the exposure and the town of Nipton, Calif., lies within $14 \mathrm{~km}$ of the outcrop.

Geologic setting: The circular stock generally intruded medium- to fine-grained quartzfeldspathic gneiss and is predominantly composed of quartz monzonite pervasively silicified and sericitized. Bingler and Bonham (1973) have indicated a Mesozoic age for the pluton, although a lead-alpha age of a granite sample was determined to be Precambrian or $927 \pm 90$ m.y. (Schilling, 1965).

Hydrologic setting: The pluton is in the Piute Valley ground-water system and Piute and Ivanpah Valleys drainage basins. Piute Valley is a tributary of the Colorado River drainage basin. The nearest discharge is $25 \mathrm{~km}$ east near the Colorado River. The river water is used for public supply, hydroelectric power, and irrigation farther downstream.

Aeromagnetic expression: No anomaly is associated with the small area of granitic rocks.

Comment: The quartz monzonite lies approximately $5.5 \mathrm{~km}$ northeast of the Nevada-California State line.

Mining activity: Mining is currently (1976) dormant in the area, but numerous mining claims are scattered along the margins of the exposure.

Selected references: Bingler and Bonham, 1973; Schilling, 1965. 


\section{CL-8. NORTHERN LUCY GREY RANGE}

General location: West of the McCullough Range and east of Roach Lake.

Coordinates: lat $35^{\circ} 39^{\prime} \mathrm{N}$., long $115^{\circ} 17^{\prime} \mathrm{W}$.

Land classification: Public domain.

Area: $28 \mathrm{~km}^{2}$.

Accessibility: Interstate 95 and the Union Pacific Railroad pass along Ivanpah Valley approximately $6 \mathrm{~km}$ and $4 \mathrm{~km}$ west of the exposure, respectively.

Remoteness: The town of Jean (population 100) lies about $10 \mathrm{~km}$ north of the outcrop and Nipton, Calif., is about $13 \mathrm{~km}$ to the south.

Geologic setting: The pluton consists of gray gneissic Precambrian granite, overlain locally along the eastern flank by Tertiary rocks. The gneissic granite is intruded by pegmatite dikes and contains subangular fragments of dark schist. The granite contains about 75 percent orthoclase crystals, as much as $5 \mathrm{~cm}$ long, that are roughly alined in a northeast-trending direction. The range is predominantly surrounded by alluvial fill. It has been suggested that the east and west flanks of the range are bounded by high-angle north-trending normal faults.

Hydrologic setting: The center of the pluton in the northern Lucy Grey Range is in the Las Vegas Valley ground-water system; the flow is dominantly northeastward under Jean Lake and Hidden Valley. Runoff from the pluton drains into Ivanpah Valley. The nearest discharge is about $62 \mathrm{~km}$ northeast near Lake Mead; however, some of the ground-water flow probably is intercepted in route by pumping wells, principally in Las Vegas Valley. The water of Lake Mead is used for public supply, irrigation, and hydroelectric power.

Aeromagnetic expression: A north- to northeast-trending positive anomaly is developed in part over the plutonic rock terrane. A noteworthy $90^{\circ}$ shift in anomaly trend from northeast to northwest occurs $15 \mathrm{~km}$ north of the mapped rocks, marking the southeastern flank of a very high amplitude, broad, positive anomaly that presumably is associated with buried Precambrian crystalline rock. The maximum areal extent of the inferred tract of buried Precambrian rocks is estimated to be $300 \mathrm{~km}^{2}$. This positive anomaly is the largest magnetic feature, with respect to both amplitude and extent, within Nevada.

Mining activity: Although no active mining occurs in the area, the Lucy Grey mine, located in the southern Lucy Grey Range, was active in the early 1900's.

Selected references: Hewett, 1956; Longwe11, Pampeyan, Bowyer, and Roberts, 1965. 
GEOLOGY

Lincoln County (fig. 5) is located in southeastern Nevada entirely within the Basin and Range province, which consists of elongated north-south mountain ranges separated by wide basins. The crests of the mountain ranges are about $900-1,200 \mathrm{~m}$ higher than the adjacent basins.

The county consists of approximately one-third Cenozoic sedimentary rocks, one-third volcanic rocks, and one-third igneous, metamorphic, and sedimentary rocks that range in age from Precambrian to Triassic (Tschanz and Pampeyan, 1970). The Paleozoic rocks make up the eastern margin of the Cordilleran miogeosyncline in the county, with the greatest thickness in the western part of the county, decreasing toward the eastern part of the county.

The structure is complex; the oldest major deformation consists of thrust faults. Two episodes of thrust faulting have occurred--Laramide and post-01igocene. The Paleozoic rocks have been displaced eastward as much as $26 \mathrm{~km}$ over younger rocks that are folded into overturned synclines beneath the thrust (Tschanz and Pampeyan, 1970). A major northeasttrending strike-slip fault of Laramide age has been inferred by Tschanz and Pampeyan (1970). It is located in the southwestern part of the county (fig. 5) and is called the Arrowhead Mine Fault. The fault has an apparent right-lateral displacement of about $40 \mathrm{~km}$. Three post-Miocene left-lateral faults occur parallel to the older right-lateral Arrowhead Mine Fault. The older structures have been offset by basin-and-range faulting and partly covered by Cenozoic rocks.

An easterly trending structure named the Timpahute Lineament (Ekren and others, 1976, fig. 5) is located in the central part of the county, traversing the county. In the western part of the county, the lineament is expressed by discontinuous east-northeast-trending topography from the Timpahute Range through the North and South Pahroc Ranges (Ekren and others, 1976). Several igneous intrusive bodies occur on or near the lineament. The lineament is the locus of recent seismicity in the southern part of the North Pahroc Range (Ekren and others, 1976) and is north of a west-southwest-trending zone of seismic activity. This seismic belt, known as the "intermountain seismic belt," is the southwestern extension of the seismic belt that continues into Lincoln County.

The geologic data were extracted and summarized from the following:

Ekren, Orkild, Sargent, and Dixon, 1978; and Tschanz and Pampeyan, 1970.

\section{HYDROLOGY}

The White River drainage basin, including a major tributary--Meadow Valley Wash--drains the central and eastern parts of Lincoln County. The White River converges with the Muddy and Virgin Rivers that flow into the Overton Arm of Lake Mead to the south in Clark County. The area along the Utah State line, southeast of Clover Creek, drains southeastward into Utah and into the Virgin River in southwestern Utah. Hamlin Valley Wash, in the northeastern part of Lincoln County, drains northward into the Snake Valley of Utah. The western and northcentral parts of the county drain locally into playas that are topographically closed. One small valley--Tule Desert--in southeastern Lincoln County, also drains centripetally into a playa. 


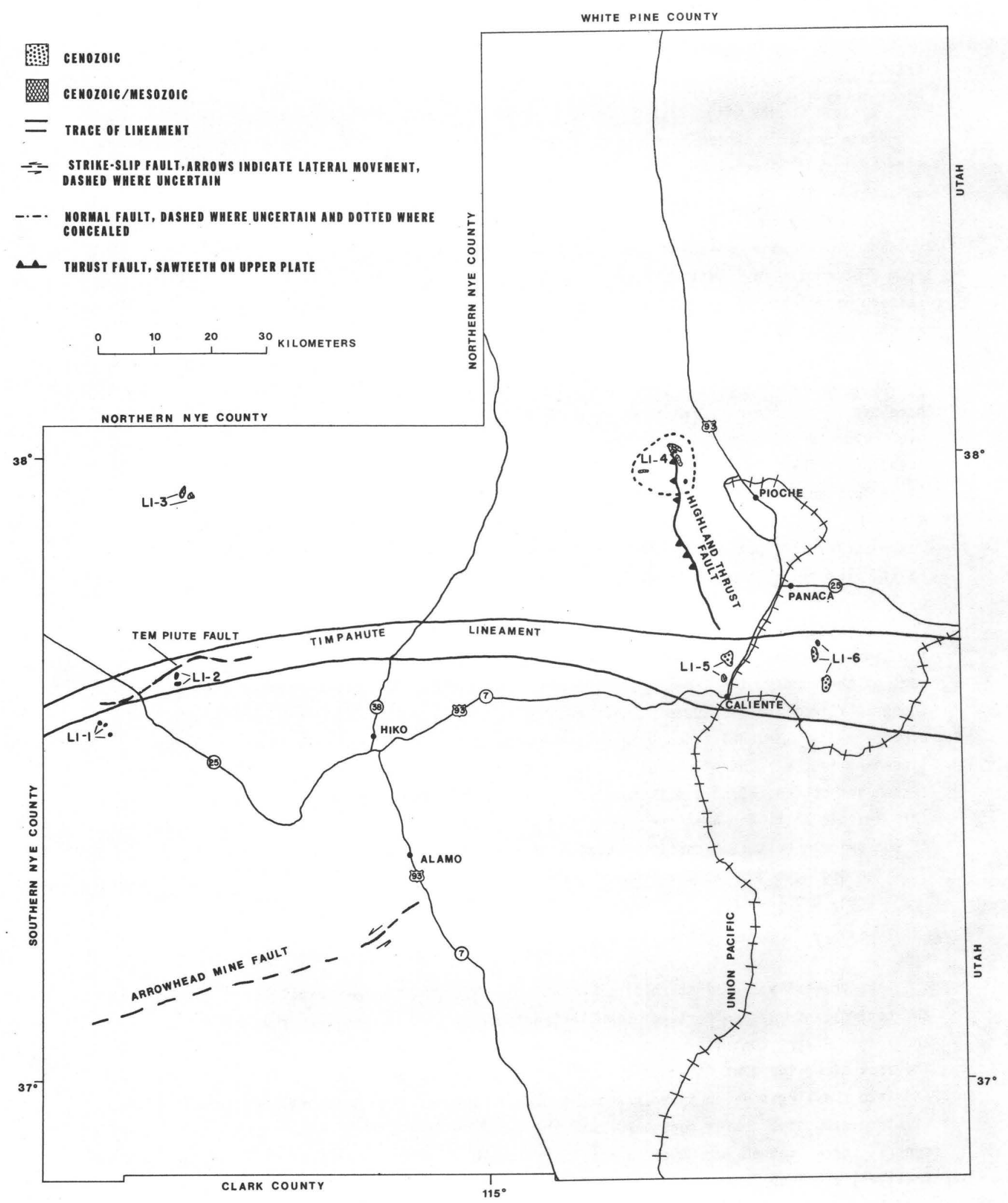

FIGURE 5.-- LOCATIONS OF PLUTONS IN LINCOLN COUNTY 
The major sources of runoff and recharge in Lincoln County are the southern parts of Quinn Canyon, Egan, and Schell Creek Ranges, also all the higher parts of Wilson Creek, Bristol, Highland, and Fortification Ranges, plus the White Rock and Mahogany Mountains. Minor sources of recharge include the Groom, Timpahute, Golden Gate, and Seaman Ranges.

The White River ground-water system, featuring southward flow, is a major aquifer system in Lincoln County; only the southwestern, northeastern, and a small area along the Utah State line east of Panaca are excluded from the White River system.

The Ash Meadows ground-water system underlies Tikaboo, Emigrant, Indian Springs, and Three Lakes Valleys in the southwest part of the county. The Ash Meadows system flows southwestward toward the Amargosa Desert and Death Valley. Hamlin Valley in northeastern Lincoln County is part of the Snake Valley ground-water system mainly in Utah. The Snake Valley system flows generally northeastward to the Great Salt Lake Desert in Utah. The small area east of Panaca is in the Escalante Desert ground-water system of Utah.

The hydrology of Lincoln County was taken principally from the following references: Eakin, 1962b, 1963a, 1963b, 1963c, 1964; Glancy and VanDenburgh, 1969; Rush, 1964; and Rush and Eakin, 1963. 
LI-1. GROOM RANGE

General location: North end of the Groom Range.

Coordinates: lat $37^{\circ} 35^{\prime}$ N., long $115^{\circ} 48^{\prime} \mathrm{W}$.

Land classification: Public domain.

Area: $1 \mathrm{~km}^{2}$ (cumulative).

Accessibility: $8 \mathrm{~km}$ southwest of State Highway 25.

Remoteness: $46 \mathrm{~km}$ west of Hiko (population 15).

Geologic setting: The exposed pluton consists of three outcrops composed of Cretaceous(?)Tertiary granite. The granitic masses intrude the Prospect Mountain Quartzite of late Precambrian and the Chisholm Shale of Cambrian age. Tertiary volcanic rocks include tuffs, andesite and basalt flows, and rhyolite intrusives.

The Groom Range is an uplifted fault block, tilted to the west and bounded by a high-angle normal fault on the west side of the block. The Prospect Mountair Quartzite has been thrusted, overriding the younger Pioche Shale (Lower and Middle Cambrian). The thrust faults have been offset by high-angle normal faults. The Tem Piute Fault, a major northeasttrending normal fault, is located $3 \mathrm{~km}$ north of the granitic outcrops.

Hydrologic setting: The pluton is in the Penoyer Valley closed ground-water system and drainage basin. The nearest discharge is $17 \mathrm{~km}$ north on the valley floor, where water is used for livestock and domestic purposes. Formerly some irrigation and industrial (milling) uses were extant. Aeromagnetic expression: The small outcrops occur along the northern flank of a northeasttrending regional positive anomaly that appears to be largely associated with ash-flow tuffs, andesite flows, and related extrusive rocks.

Comment: The pluton is $3 \mathrm{~km}$ south of the Tem Piute Fault. 


\section{LI-2. LINCOLN STOCK}

General location: Northeast flank of Tempiute Mountain, western part of the Timpahute

Range.

Coordinates: lat $37^{\circ} 39^{\prime}$ N., long $115^{\circ} 37^{\prime}$ W.

Land classification: Public domain and patented mining claims.

Area: $2 \mathrm{~km}^{2}$ (cumulative).

Accessibility: $6 \mathrm{~km}$ northeast of State Highway 25.

Remoteness: $1 \mathrm{~km}$ east of Tempiute (population 10 ) and $35 \mathrm{~km}$ northwest of Hiko (population 15).

Geologic setting: The Lincoin stock is composed of two outcrops of Cretaceous granite. The granitic bodies intrude the following: Devonian Guilmette Formation made up of limestone, dolomite, and quartzite; limestone of Mississippian age; Chainman Shale and Scotty Wash Quartzite, both of Mississippian age; and limestone of Pennsylvanian age. The pluton has

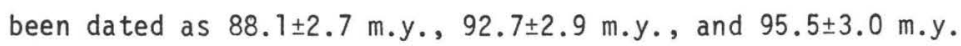
(Krueger and Schilling, 1971).

Two major thrust faults of Laramide age that disrupt the Paleozoic rocks are found in the area. The thrust faults are offset by high-angle normal faults of Tertiary age. The pluton is located $1 \mathrm{~km}$ southeast of the Tem Piute Fault (fig. 5), a major northeast-trending high-angle normal fault.

Hydrologic setting: The pluton is in Penoyer Valley ground-water system and drainage basin. The nearest discharge is $15 \mathrm{~km}$ northwest in the playa; a ranch well $7 \mathrm{~km}$ northwest probably intercepts some of the ground-water flow. Water is used in the valley for livestock and domestic purposes and, formerly, for irrigation and industrial purposes.

Aeromagnetic expression: These outcrops occur along the northern flank of the regional positive anomaly referred to in LI-1, about $15 \mathrm{~km}$ northeast of the outcrops of LI-1.

Mining activity: Tungsten mining in the immediate vicinity of the pluton.

Comment: Pluton near active mine.

Selected reference: Krueger and Schilling, 1971. 


\section{LI-3. WORTHINGTON PEAK}

General location: North end of the Worthington Mountains

Coordinates: lat $37^{\circ} 57^{\prime} \mathrm{N}$., long $115^{\circ} 36^{\prime} \mathrm{W}$.

Land classification: Public domain.

Area: $3 \mathrm{~km}^{2}$ (cumulative).

Accessibility: $33 \mathrm{~km}$ northeast of State Highway 25.

Remoteness: $100 \mathrm{~km}$ northwest of Caliente (population 916), $51 \mathrm{~km}$ northwest of Hiko

(population 15).

Geologic setting: The Worthington Peak pluton consists of two granitic rock exposures of

Cretaceous-Tertiary granite. The granite intrudes the Pogonip Group

made up of limestones of Ordovician age, the Ordovician Eureka

Quartzite, and the Devonian Sevy Dolomite.

The Worthington Mountains are a north-trending mountain range, probably

bounded on both sides by normal faults. The major structure consists

of thrust faults displacing the Paleozoic rocks, with high-angle

normal faults offsetting the thrust plates.

Hydrologic setting: The pluton is in the White River ground-water system and Garden Valley drainage basin. The nearest discharge is $49 \mathrm{~km}$ southeast in white River Valley. Water is used in this part of the valley for livestock, domestic, and irrigation purposes.

Aeromagnetic expression: The outcrops of granitic rock occur along the northeastern flank of a northwest-trending, high-amplitude positive anomaly, which has an unknown source at depth.

Comment: The pluton is near major high-angle normal faults. 
LI-4. BRISTOL RANGE

General location: West flank of the Bristol Range near Blind Mountain Spring.

Coordinates: lat $38^{\circ} 00^{\prime}$ N., long $114^{\circ} 37^{\prime} \mathrm{W}$.

Land classification: Public domain.

Area: $3 \mathrm{~km}^{2}$ (cumulative).

Accessibility: $7 \mathrm{~km}$ west of U.S. Highway 93 and $9 \mathrm{~km}$ northwest of the Union Pacific Railroad.

Remoteness: $17 \mathrm{~km}$ northwest of Pioche (population 600).

Geologic setting: The Bristol Range pluton is composed of Tertiary quartz monzonite, which intrudes the Prospect Mountain Quartzite of late Precambrian and Cambrian age and the Chisholm Shale, Lyndon Limestone, and the Highland Peak Formation--al1 of Cambrian age--and the Guilmette Formation, made up of 1 imestone, dolomite, and quartzite of Devonian age. Tertiary volcanic rocks overlie the Paleozoic rocks in some areas. The quartz monzonite has been dated at $27.7 \pm 0.9$ m.y. (Armstrong, 1970).

The Paleozoic rocks have been thrust eastward along the Highland Thrust Fault (fig. 5) which is located $0.5 \mathrm{~km}$ southwest of the pluton. The thrust fault has been offset by younger high-angle normal faults.

Hydrologic setting: The pluton is in the Meadow Valley ground-water system and the Dry Lake Valley and Patterson Wash drainage basin. The nearest significant discharge is $28 \mathrm{~km}$ southeast in Meadow Valley Wash, a tributary of White River. Water is used in the area for irrigation, livestock, public supply, and domestic purposes.

Aeromagnetic expression: The granitic rocks occur along the northeastern margin of a highamplitude positive anomaly that appears to be associated with ash-flow tuffs and related extrusive rocks.

Comment: Pluton is near Highland Thrust Fault.

Selected reference: Armstrong, 1970a. 


\section{LI-5. CHIEF RANGE}

General location: Southern part of the Chief Range.

Coordinates: lat $37^{\circ} 41^{\prime}$ N., long $114^{\circ} 30^{\prime}$ W.

Land classification: Public domain.

Area: $6 \mathrm{~km}^{2}$ (cumulative).

Accessibility: $1 \mathrm{~km}$ west of U.S. Highway 93.

Remoteness: $4 \mathrm{~km}$ northwest of Caliente (population 916).

Geologic setting: The pluton is composed of Tertiary granodiorite, which probably is related to the Caliente volcanic center that is located approximately $15 \mathrm{~km}$ southwest of the pluton; the granodiorite is possibly part of a ring-fracture system. The granodiorite intrudes the Prospect Mountain Quartzite of late Precambrian and Cambrian age and the Pioche Shale, and limestone, dolomite, and other shale, all of Cambrian age. The Paleozoic rocks are overlain unconformably by Tertiary volcanic rocks.

The Chief Range is an uplifted east-tilted fault block. The Paleozoic rocks in the area have been displaced by the Highland Thrust Fault and later offset by high-angle normal faults of Tertiary age.

Hydrologic setting: The pluton is in the Meadow Valley ground-water system and the Meadow Valley wash drainage basin. The nearest discharge is $2 \mathrm{~km}$ east, where water is used principally for livestock, domestic, and irrigation purposes.

Aeromagnetic expression: The main area of the granitic rocks occurs at the eastern flank of a high-amplitude positive anomaly associated in part with andesitic flows and related extrusive rocks.

Comment: The pluton is near the town of Caliente and in the vicinity of the Highland Thrust Fault. 


\section{LI-6. CEDAR RANGE}

General location: Western part of the Cedar Range.

Coordinates: lat $37^{\circ} 39^{\prime}$ N., long $114^{\circ} 18^{\prime} \mathrm{W}$.

Land classification: Public domain.

Area: $6 \mathrm{~km}^{2}$ (cumulative).

Accessibility: $12 \mathrm{~km}$ east of U.S. Highway 93. Union Pacific Railroad located $5 \mathrm{~km}$ southwest of pluton.

Remoteness: $16 \mathrm{~km}$ east of Caliente (population 916) and $10 \mathrm{~km}$ southeast of Panaca

(population 500).

Geologic setting: Several scattered outcrops of Tertiary diorite and granite occur in the Cedar Range. The granitic rocks are probably related to the Caliente volcanic center and probably make up a ring-fracture system related to the Caliente volcanism. The granitic bodies intrude intermediate lavas and welded tuffs of Tertiary age.

The structure of the area consists of northeast- and northwest-trending high-angle normal faults.

Hydrologic setting: The pluton is in the Meadow Valley ground-water system and Meadow Valley Wash drainage basin. The nearest significant discharge is $15 \mathrm{~km}$ west, where water is used principally for livestock, domestic, and irrigation purposes.

Aeromagnetic expression: The largest tract of the granitic rocks occurs at the center of a high-amplitude positive anomaly and is presumably the source of the anomaly. The entire anomaly source is estimated to have a maximum areal extent of as much as $15 \mathrm{~km}^{2}$. 


\section{SOUTHERN NYE COUNTY}

\section{GEOLOGY}

Nye County has been divided into southern and northern Nye County. Southern Nye County will be discussed in this section and northern Nye County will be discussed later in the text.

The southern part of Nye County is located in southwestern Nevada. Only the granitic rocks that occur on the Nellis Air Force Base Bombing and Gunnery Range in the northern half of the area will be considered. Other granitic rocks in the county occur within the Nevada Test Site in the southern half of the area and will not be discussed further; however, the intrusives are shown on the granitic map (p1. 7) and county map (fig. 6):

SN-1. Microgranite of Timber Mountain

$\mathrm{SN}-2$. Wahmonie granodiorite

$\mathrm{SN}-3$. Twinridge stock

$\mathrm{SN}-4$. Climax stock

SN-5. Gold Meadows stock

The northern half of the area consists of volcanic rocks of Tertiary age (27 to $7 \mathrm{~m} . \mathrm{y}$. ) making up at least 90 percent of the outcrops (Ekren and others, 1971), and the remainder of the area consists of sedimentary rocks of late Precambrian and Paleozoic age. The Tertiary rocks consist chiefly of ash-flow tuffs, silicic lavas, interbedded ash-fall tuff, and tuffaceous sedimentary rocks. Several volcanic centers occur in the area and are sources for the volcanic rocks. The area is about $80 \mathrm{~km}$ east of the eastern border of the Cordilleran eugeosyncline.

The northern half of the area consists primarily of alluvial valleys separated by northerly trending mountain ranges and closed basins. Basin-and-range high-angle normal faults bound the mountain ranges. Two normal fault systems are present in the area (Ekren and others, 1971)--an earlier system that consists of two sets of faults that strike northeast and northwest, and a later system that strikes north. Three-quarters of the area lies partly within or near the Walker Lane Fault Zone (pl. 4) that enters the county at the southeastern boundary.

The rocks on the Nellis Air Force Base Bombing and Gunnery Range are exposed granitic bodies, except for the Trappman Hills (SN-7) area, which suggests an underlying unexposed granitic mass that is considered here because of its close proximity to the Nevada Test Site.

The geologic data were extracted and summarized from the following:

Cornwa11, 1972; and Ekren, Anderson, Rogers, and Noble, 1971.

\section{HYDROLOGY}

The southwestern third of the area is drained mostly by the Amargosa River, an intermittent stream that empties into Death Valley. The remainder of the area is composed of topographically closed drainage basins.

The chief source of recharge and runoff in the area is precipitation on the western Spring and Grapevine Mountains, and on the Kawich, Reveille, and Belted Ranges.

The Ash Meadows ground-water system underlies the southern and eastern part of southern Nye County; ground water migrates generally southwestward in this system. 


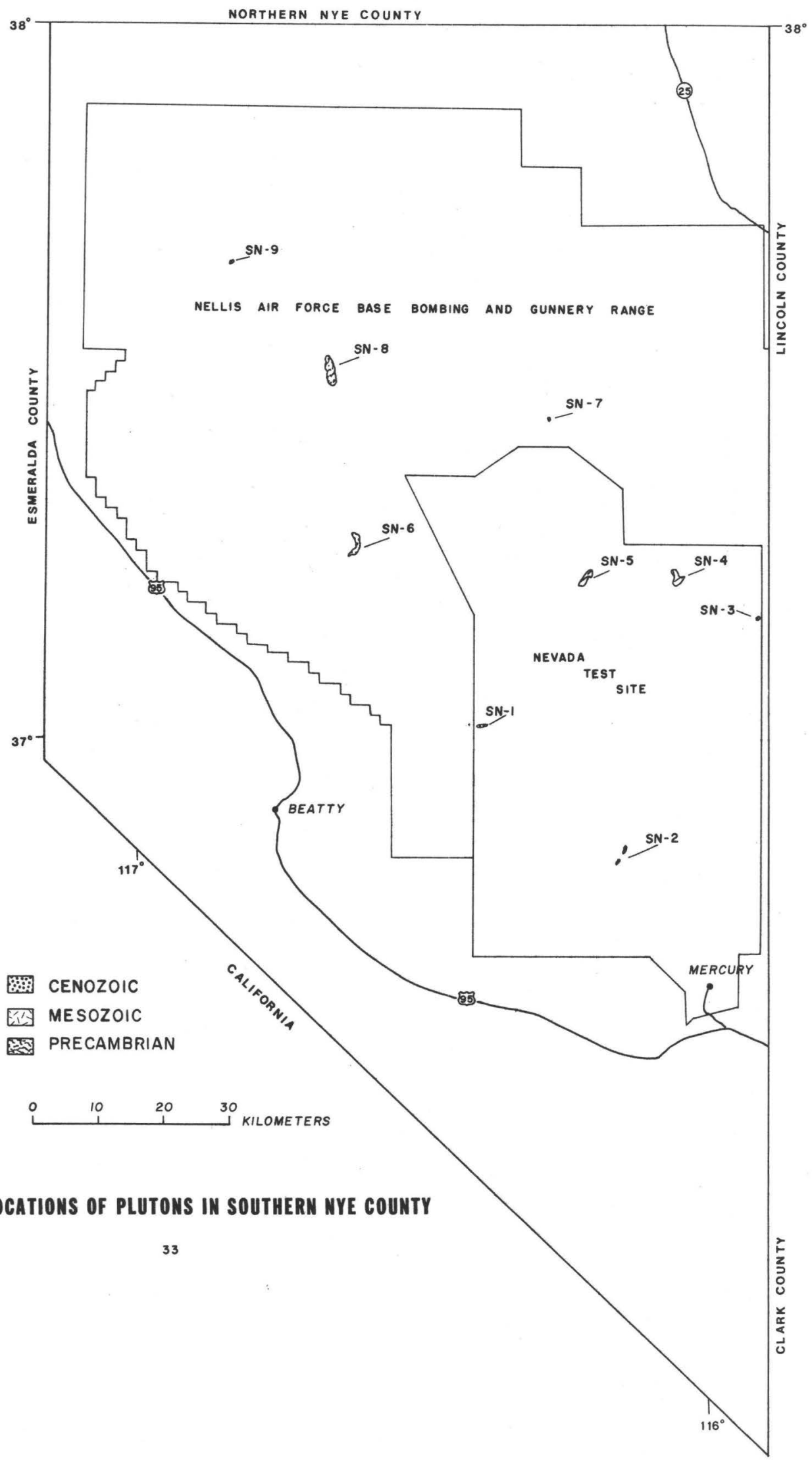


The Pahute Mesa ground-water system is in the central and southern part of the county; the system features southward migration of ground water parallel in general to the adjacent Ash Meadows system. Some water is transmitted from the Pahute Mesa system to the Ash Meadows system in the Amargosa Desert. The Sarcobatus Flat and Clayton Valley ground-water systems, featuring parallel southwestward movement, underlie the northwestern part of southern Nye County. Water migrates northeast in Railroad Valley, in the northeast corner of the area; that system is designated Railroad Valley ground-water system.

The hydrology of southern Nye County was taken primarily from the following references:

Blankennagel and Weir, 1973; Malmberg and Eakin, 1962; Rush, 1970; Walker and Eakin, 1963; and Winograd and Thordarson, 1975. 
[Exclusive of SN-1 through SN-5 within the Nevada Test Site]

\section{SN-6. BLACK MOUNTAIN SYENITE}

General location: Black Mountain.

Coordinates: lat $37^{\circ} 16^{\prime} \mathrm{N}$., long $116^{\circ} 37^{\prime} \mathrm{W}$.

Area: $21 \mathrm{~km}^{2}$.

Land classification: Nellis Air Force Base Bombing and Gunnery Range.

Accessibility: $23 \mathrm{~km}$ northeast of U.S. Highway 95.

Remoteness: $41 \mathrm{~km}$ northeast of Beatty (population 900) and $86 \mathrm{~km}$ northwest of Mercury.

Geologic setting: The syenite is located within the multiple-collapse Black Mountain caldera that erupted ash-flow tuffs and lavas of Miocene to Pliocene age. The oldest rocks (Christiansen and Noble, 1965) erupted are latitic lavas that are unconformably overlain by a sequence of latitic, trachytic, and rhyolitic lavas. The Thirsty Canyon Tuff (6.5-7.5 m.y.) was emplaced after extrusion of these lavas (Noble and others, 1965). The syenite is light gray to grayish brown, porphyritic, locally grading to trachyte, and strongly jointed. The syenite body has been mapped as part of the rocks of Yellow Cleft, which include tuffs and lavas older than the Thirsty Canyon Tuff.

Hydrologic setting: The caldera is in the Pahute Mesa ground-water system and the Amargosa River and Gold Flat drainage basins. The nearest discharge is $24 \mathrm{~km}$ south in Oasis Valley. Water is used in the valley for irrigation, livestock, domestic, and public supply.

Aeromagnetic expression: The curvature of the granitic rock exposures coincides with the curvature of an elliptical high-amplitude positive anomaly, which presumably is related to the geometric configuration of the caldera.

Comment: Pluton located on Nellis Air Force Base Bombing and Gunnery Range and within the Walker Lane Fault Zone.

Selected reference: Christiansen and Noble, 1965; Noble, Kister, Christiansen, Lipman, and Poole, 1965. 
General location: Southeastern flank of Quartzite Mountain, southern Kawich Range.

Coordinates: lat $37^{\circ} 27^{\prime}$ N., long $116^{\circ} 16^{\prime} \mathrm{W}$.

Land classification: Nellis Air Force Base Bombing and Gunnery Range.

Area: Less than $1.0 \mathrm{~km}^{2}$.

Accessibility: $61 \mathrm{~km}$ northeast of U.S. Highway 95 and $42 \mathrm{~km}$ southwest of State Highway 25.

Remoteness: $74 \mathrm{~km}$ northeast of Beatty (population 900) and $91 \mathrm{~km}$ northwest of Mercury.

Geologic setting: The Gold Reed pluton is composed of granite of Mesozoic age that intrudes the upper member of the Stirling Quartzite (Precambrian), which includes siltstone, quartzite, dolomite, limestone, and silty phyllite. The Stirling Quartzite has been metamorphosed for a distance of approximately $2 \mathrm{~km}$ adjacent to the granite outcrop. The granite mass is almost completely covered by alluvium and its dimensions are unknown. The granite mass is part of an uplifted fault block which has high-angle normal faults as the predominant structure.

Hydrologic setting: The pluton is in the Pahute Mesa ground-water system. Runoff drains into Kawich Valley to the east, which is closed topographically. The nearest discharge is $56 \mathrm{~km}$ southwest in 0asis Valley. Water is used in the valley for irrigation, livestock, domestic, and public supply. Aeromagnetic expression: The small outcrop occurs at the northern margin of a high-amplitude positive anomaly that apparently is associated with extrusive and shallow intrusive rocks. Positive anomalies occur over similar extrusive rocks within a radius of $20 \mathrm{~km}$ from the anomaly center. Comment: Pluton located on Nellis Air Force Base Bombing and Gunnery Range. 


\section{SN-8. TRAPPMAN HILLS}

General location: Trappman Hills, occur between Mount Helen and Gold Flat.

Coordinates: lat $37^{\circ} 30^{\prime} \mathrm{N}$., long $116^{\circ} 39^{\prime} \mathrm{W}$.

Land classification: Nellis Air Force Base Bombing and Gunnery Range.

Area: $21 \mathrm{~km}^{2}$.

Accessibility: $41 \mathrm{~km}$ northeast of U.S. Highway 95 and $65 \mathrm{~km}$ southwest of State Highway 25. Remoteness: $66 \mathrm{~km}$ northeast of Beatty (population 900) and $110 \mathrm{~km}$ northwest of Mercury. Geologic setting: The Trappman Hills are composed of a complex of Precambrian gneiss and schist that form low, rounded hills. The Trappman Hills are formed by a north-northwest-trending uplifted fault block consisting of high-angle normal faults. The following evidence suggests that a possible pluton underlies the Trappman Hills:

(1) The outcrop is the only known exposure of Precambrian crystalline rocks in the area,

(2) The Trappman Hills appear to have been uplifted or domed up, and

(3) The rhyolite porphyry dikes that intrude the gneiss/schist complex could possibly be related to an underlying granitic body.

Hydrologic setting: The hills are in the Pahute Mesa ground-water system. Runoff drains southeastward into Gold Flat, which is topographically closed. The nearest discharge point is $49 \mathrm{~km}$ south in Oasis Valley, where the water is used for irrigation, livestock, domestic, and public suppiy. Aeromagnetic expression: No well-developed anomaly is associated with the granitic rocks. Comments: Area needs further work to establish if, indeed, there is a pluton underlying Trappman Hills. The pluton(?) is located on the Nellis Air Force Base Bombing and Gunnery Range and within the Walker Lane Fault Zone., 
SN-9. CACTUS RANGE

General location: Southwest flank of the Cactus Range.

Coordinates: lat $37^{\circ} 40^{\prime} \mathrm{N}$., long $116^{\circ} 52^{\prime} \mathrm{W}$.

Land classification: Nellis Air Force Base Bombing and Gunnery Range.

Area: Less than $1.0 \mathrm{~km}^{2}$.

Accessibility: $38 \mathrm{~km}$ northeast of U.S. Highway 95 and $75 \mathrm{~km}$ southwest of State Highway 25. Remoteness: $85 \mathrm{~km}$ north of Beatty and $134 \mathrm{~km}$ northwest of Mercury.

Geologic setting: The Cactus Range pluton is composed of Mesozoic granite which intrudes the Eleana Formation of Devonian and Mississippian age and the Halfpint Member of the Nopah Formation composed of limestone and dolomite of Cambrian age. Other rock units in the area include the following Tertiary volcanic rocks: tuffs of Antelope Springs, tuff of White Blotch Springs, and coarse-grained porphyritic rhyolite and quartz latite porphyritic intrusives.

The Cactus Range is a volcanic center and is the source of most of the volcanic rocks in the area. The mountain range is a northwesttrending uplifted fault block and consists predominantly of high-angle normal faults having northwest, east, and northeast trends. The Cactus Range lies on the Walker Lane Fault Zone.

Hydrologic setting: The pluton is in the Sarcobatus Flat ground-water system. Runoff drains to Stonewall Flat. The nearest discharge is $52 \mathrm{~km}$ southwest in Sarcobatus Flat. Water is used in the flat for livestock purposes; however, a small amount of the flow may be intercepted by a few domestic wells before it reaches Sarcobatus Flat.

Aeromagnetic expression: The small outcrop occurs along the southeastern flank of a northwest-trending high-amplitude positive anomaly that is presumably associated with similarly trending ash-flow tuffs and related extrusive rocks.

Comment: Pluton located on the Nellis Air Force Base Bombing and Gunnery Range and in the Walker Lane Fault Zone. 


\section{NORTHERN NYE COUNTY}

\section{GEOLOGY}

The northern part of Nye County has been defined as that part of Nye County north of the 38th parallel, occupying nearly $28,600 \mathrm{~km}^{2}$ in central Nevada (fig. 7). This part of the county is centrally located within the Basin and Range province, which is characterized by a series of north- to northeast-trending mountain ranges separated by alluvial basins developed during late Tertiary time. The ranges are largely covered by thick sequences of Tertiary volcanic rocks, commonly composed of rhyolitic flows and welded and nonwelded silicic ashflow tuffs. Exposures of granitic rocks found within the county intrude a wide variety of pre-Cenozoic sedimentary rocks, ranging in age from late Paleozoic to Mesozoic. The intrusives generally are exposed along steep, tilted range fronts marked by high-angle normal faults where erosion has stripped away the Tertiary cover.

Tertiary granitic intrusions occurring along the eastern margin of the county (White Pine and Grant Ranges) cut rocks referred to as the carbonate and transitional assemblages, consisting of limestone, dolomite, and minor amounts of shale and quartzite, and ranging in age from Early Cambrian to Devonian. These ranges lie east of the Mississippian Antler orogenic belt, where the structure is dominated by north-trending folds and thrusts which developed during Laramide time (Sevier orogeny) in the late Mesozoic. These structures are cut by a series of low-angle faults that placed younger rocks over older rocks.

Progressing eastward to the central part of the county (Toquima and Toiyabe Ranges), Cenozoic and Mesozoic plutonic rocks, mostly quartz-monzonite and granodiorite, intrude a wide variety of lithologic assemblages. These are (1) upper Paleozoic and Mesozoic rocks of the western siliceous and volcanic assemblage, predominantly composed of chert, argillite, and greenstone; (2) shale and chert of lower Paleozoic siliceous assemblage; (3) phyllite, shale, and limestone of lower Paleozoic transitional assemblage; and (4) quartzite, siltstone, and carbonates of lower Paleozoic eastern carbonate assemblage.

Rocks underlying north-central Nye County have undergone at least two major periods of deformation during Paleozoic and Mesozoic time. During the Antler orogeny, in Late Devonian to Early Mississippian time, western siliceous and volcanic assemblage rocks were thrust eastward over the transitional and eastern carbonate assemblages. Then, during the Sonoma orogeny, in Late Permian and Early Triassic time, a thick western accumulation of chert, limestone, shale, and phyllite was transported eastward along the Golconda thrust. Both events led to the juxtaposition of the diverse facies described above.

East of the Toiyabe Range, Mesozoic and Cenozoic granitic rocks intrude thick sequences of intercalated clastic, carbonate, and metavolcanic rocks of late Paleozoic(?) and Mesozoic age. These intruded rocks are included in the Gabbs, Sunrise, Luning, and Pablo Formations, prevalent in the adjoining Mineral County. Deposition was interrupted during the Jurassic age by the Nevada orogeny. Folding and thrusting associated with this event were directed southward and eastward. The primary reference for northern Nye County is Kleinhampl and Ziony, 1967. 


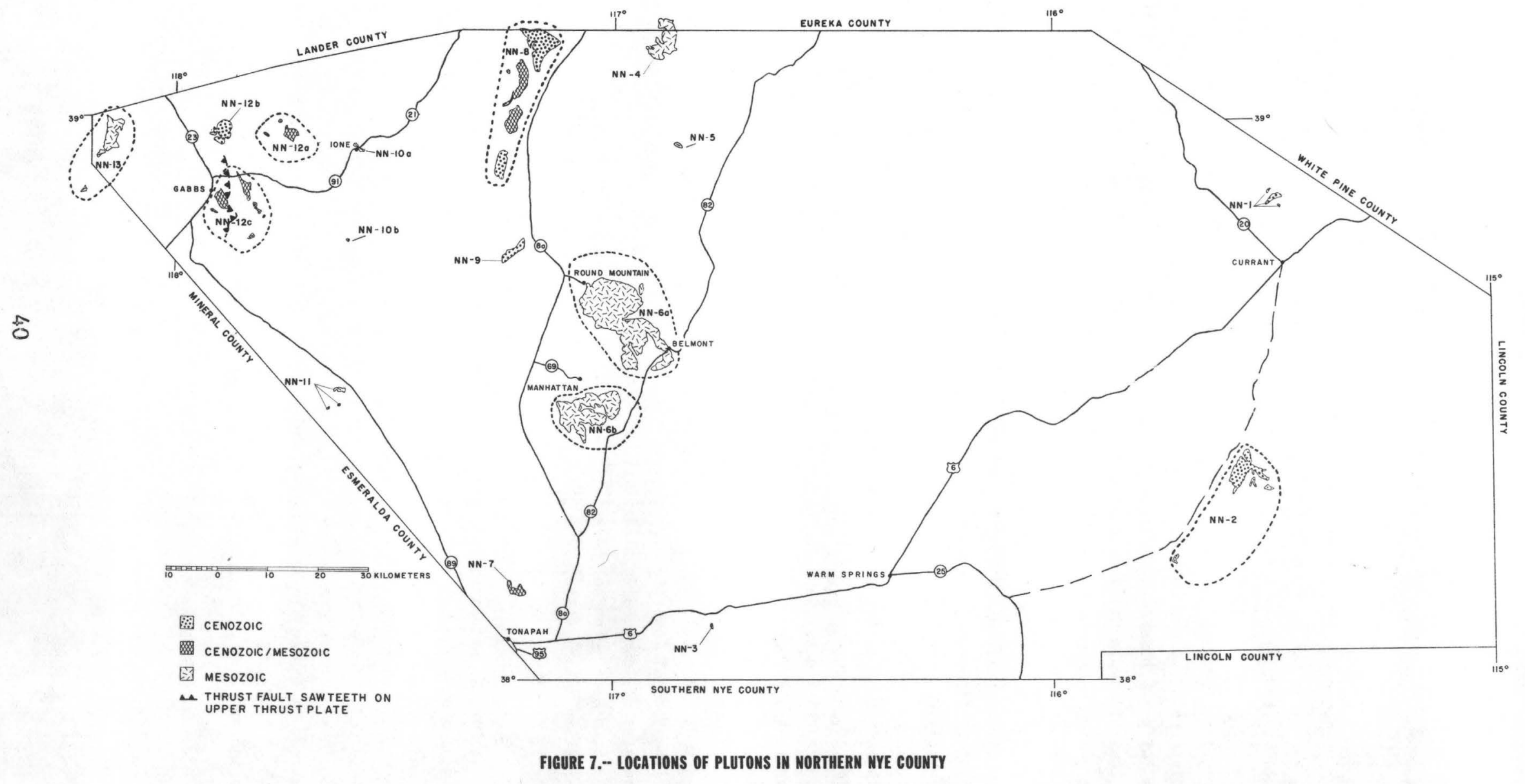


HYDROLOGY

Northern Nye County, Nev., is located in the central Great Basin. Including the Reese River, a tributary of the Humboldt. The eastern part of the area drains to the Colorado River via the ephemeral White River. Another ephemeral stream, Reese River, heads in westcentral Nye County and flows northward into the Humboldt River near Battle Mountain. Runoff flows to playas or other intermittent streams in the various valleys ( $p 1,3 a)$.

Gabbs Valley playa discharges ground water by evaporation and the valley is thought to be a closed ground-water system. Ground-water movement is generally westward in the Nye County part of this valley.

Ground water beneath Ione Valley moves southward and into Big Smoky Valley, where circulation is south-southwesterly toward the Columbus Salt Marsh and Clayton Valley, into Esmeralda County. For purposes of this report, this system is designated Clayton Valley ground-water system. Ralston, Stone Cabin, and Little Fish Lake Valleys also feed ground water into the Clayton Valley ground-water system.

The Railroad Valley ground-water system receives water by subflow from Hot Creek Valley and the southern part of Little Smoky Valley. Ground water moves northward from northern Little Smoky Valley into Newark Valley (White Pine County) and this flow system is designated Newark Valley ground-water system,

The White River ground-water system, whose movement is generally southward, receives subflow from Garden and Coal Valleys.

The Reese River ground-water subsystem features movement out of the county northward down the valley toward the Humboldt River Valley. The Reese River subsystem is tributary to the areally extensive Humboldt River Valley surface- and ground-water hydrologic systems to the north.

Recharge areas of significance include the mountain ranges higher than about 2,440 $\mathrm{m}$ altitude. From west to east in the county, the principal sources of precipitation for recharge to the ground-water systems are:

Shoshone Mountains

Toi yabe Range

Toquima Range

Monitor Range

The chain consisting of the Quinn Canyon, Grant, and White Pine Ranges

Egan Range (southern part)

of somewhat less importance to sources of recharge are:

Paradise Range

The chain consisting of the Hot Creek and Antelope Ranges

Pancake Range

Recharge occurs mainly on the flanks of these ranges where runoff crosses permeable rock units. Carbonate rocks and some fractured volcanic rocks in the central parts of some of the ranges transmit recharge to the major aquifers of the region

The hydrology of northern Nye County was taken largely from the following references: Eakin, 1962a, 1962b, 1966; Everett and Rush, 1964; Rush and Everett, 1964, 1966b; Rush and Schroer, 1970; and Van Denburgh and Rush, 1974. 


\section{NN-1. RAILROAD AND SILVER SPRINGS}

General location: Western flank of the southern White Pine Range,

Coordinates: lat $38^{\circ} 52^{\prime} \mathrm{N}$., long $115^{\circ} 29^{\prime} \mathrm{W}$.

Land classification: Humboldt National Forest.

Area: $4 \mathrm{~km}^{2}$.

Accessibility: State Highway 20 passes within $7 \mathrm{~km}$ of the outcrop.

Remoteness: The town of Currant 1 ies $13 \mathrm{~km}$ to the south.

Geologic setting: The two northern exposures (Railroad stock) and the small circular outcrop to the southeast (Silver Springs stock) are chiefly composed of quartz monzonite. Radiometric ages of biotite are 27 and 31 m.y. (Schilling, 1965). The intrusions are emplaced into undivided Cambrian shales and limestones that dip away from the intrusives. The host rocks are locally metamorphosed near the margins of the intrusives and large dikes radiate outward from the stocks, generally in north and northeast directions. Along the northwest and southern boundaries, the granite mass appears to have intruded along zones of weakness associated with preintrusive thrust faults.

The Railroad stock is characterized by a high degree of fracturing.

A high-angle normal fault downthrown to the west, displaces the alluvium northwest of the pluton and is inferred to extend along the western boundary of stock.

Hydrologic setting: The Railroad and Silver Springs stocks are located in the Railroad Valley ground-water and drainage systems. The nearest ground-water discharges are springs along the Duckwater Creek, $15 \mathrm{~km}$ to the west. The water is used for irrigation and domestic purposes.

Aeromagnetic expression: The northeast-trending main exposure of plutonic rocks is intersected at right angles by a northwest-trending low-amplitude positive anomaly. Because two other outcrops of these rocks northwest and northeast of the main exposure occur within the confines of the anomaly, the anomaly source is tentatively inferred to consist of plutonic rocks having a maximum areal extent of $5-10 \mathrm{~km}^{2}$.

Mining activity: The Eagle Springs and Currant oil fields are in Railroad Valley approximately $28 \mathrm{~km}$ southwest of the site.

Selected references: Lumsden, 1964; Moores, Scott, and Lumsden, 1968; and Schi11ing, 1965. 


\section{NN-2. TROY PEAK}

General location: Adjacent to Timber Mountain at Troy Canyon in the southern Grant Range. An isolated outcrop of granitic rock 1 ies $17.5 \mathrm{~km}$ southwest of the main stock.

Coordinates: lat $38^{\circ} 22^{\prime}$ N., long $115^{\circ} 34^{\prime} \mathrm{W}$.

Land classification: Humboldt National Forest.

Area: $27 \mathrm{~km}^{2}$ (cumulative).

Accessibility: A light-duty improved road passes within $3 \mathrm{~km}$ of the main exposure and intersects U.S. Highway 6 at Currant.

Remoteness: The town of Currant (population 507) lies approximately $44 \mathrm{~km}$ north of the granite at Troy Canyon.

Geologic setting: The Troy Peak pluton is composed mainly of quartz monzonite and minor amounts of granodiorite. A radiometric age of $23(+4,-2)$ m.y. is reported (Schilling, 1965). Field relations infer a radiometric resetting of a Cretaceous pluton.

The stock intrudes the Precambrian and Cambrian Prospect Mountain Quartzite and its shale and limestone facies, the Middle Cambrian Pole Canyon Limestone, and Ordovician limestone of the Pogonip Group.

Several normal and thrust faults have been mapped within the surrounding country rock but do not cut the granitic mass. A north-trending normal fault displaces the alluvium along the western flank of the stock.

Hydrologic setting: The discontinuous outcrops of the Troy Peak pluton are near the divide between Railroad Valley and White River ground-water systems. The exposures are within the Railroad Valley ground-water and drainage systems. The nearest discharge point is $5 \mathrm{~km}$ to the west from the northern outcrop and $15 \mathrm{~km}$ northeast from the southern exposure. The water is used for irrigation and livestock purposes.

Aeromagnetic expression: The main mass of mapped rocks is associated with the southern flank of a broad north-trending high-amplitude positive anomaly. The anomaly is inferred to have a plutonic rock source which extends somewhat discontinuously northward from the exposed rocks for a distance of $40 \mathrm{~km}$. The maximum areal extent of the buried source rocks may be as great as $100-150 \mathrm{~km}^{2}$.

Mining activity: The Eagle Springs and Currant oil fields in Railroad Valley are approximately $24 \mathrm{~km}$ north of the site. Several abandoned oil wells are within $12 \mathrm{~km}$ of the main stock.

Selected reference: Schilling, 1965. 
NN-3. BLACK BUTTE

General location: Southeast of the Monitor Range.

Coordinates: lat $38^{\circ} 06^{\prime}$ N., long $116^{\circ} 47^{\prime}$ W.

Land classification: Public domain.

Area: Less than $1 \mathrm{~km}^{2}$.

Accessibility: U.S. Highway 61 ies $2.5 \mathrm{~km}$ north of the exposure.

Remoteness: The area lies $41 \mathrm{~km}$ east of Tonopah (population 1,716).

Geologic setting: The exposed granodiorite is overlain by younger rhyolites composed of domes, plugs, and flows of Miocene or Pliocene age and subordinate andesite flows of 01 igocene age. Tertiary basalt and andesite flows also occur in the vicinity. The eastern edge of the outcrop is marked by a northtrending normal fault.

Hydrologic setting: Black Butte is within the Clayton Valley ground-water system and the Stone Cabin Valley drainage basin. The nearest discharge of ground water is Clayton Valley, $66 \mathrm{~km}$ southwest. Ground water is used in the region for domestic and industrial purposes.

Aeromagnetic expression: The exposed rocks occur along the northern flank of a high-amplitude positive anomaly. Although possible sources of the anomaly include one or a combination of ash-flow tuffs and andesitic and basaltic flows, the outcrop patterns of these extrusive rocks do not geometrically conform with the northerly trend of the anomaly. Therefore, it is possible that a subsurface extension of the granodiorite serves as the principal anomaly source. If so, the subsurface plutonic rock is inferred to have a maximum areal extent of $10-15 \mathrm{~km}^{2}$. 
NN-4. CLIPPER GAP

General location: Western flank of the Toquima Range directly south of the northern border of Nye County.

Coordinates: 1at $39^{\circ} 09^{\prime} \mathrm{N}$., long $116^{\circ} 53^{\prime} \mathrm{W}$.

Land classification: Toiyabe National Forest.

Area: $24 \mathrm{~km}^{2}$.

Accessibility: State Highway 8 A passes along the west side of Big Smoky Valley about $14 \mathrm{~km}$ west of the exposures.

Remoteness: The town of Austin (population 300) in Lander County, lies about 40 km northwest of the exposure.

Geologic setting: The pluton is composed mostly of quartz monzonite and smaller amounts of granodiorite and granite cut by alaskite dikes. A potassium-argon age of biotite from the pluton is about $150 \mathrm{m.y}$. (Stewart and Mckee, 1977).

Along its northeastern boundary, the pluton is in contact with chert, siltstone, and volcanic rocks of Ordovician age. Stratification in the Paleozoic rocks parallels the contact in a zone about $400 \mathrm{~m}$ wide. Contact metamorphism and satellitic dikes of aplite and diorite are pronounced features within this zone. Miocene tuffs of Meadow Creek and 01 igocene tuffs of Moores Creek overlap the pluton along the eastern and southern borders, respectively. The alluvium of Big Smoky Valley covers the stock along the western margin.

Hydrologic setting: Clipper Gap pluton is within the northern Big Smoky Valley ground-water system and drainage basin. The nearest discharge area is $8 \mathrm{~km}$ to the west. Water usage includes domestic, irrigation, and livestock.

Aeromagnetic expression: A regional, elliptical, north-trending, high-amplitude positive anomaly is clearly associated with the mapped plutonic rocks. The areal extent of the anomaly source is estimated to be about the same as that of the exposed rocks.

Selected references: McKee, 1972; Stewart and McKee, 1977. 
NN-5. NORTHUMBERLAND

General location: Eastern flank of the Toquima Range.

Coordinates: lat $38^{\circ} 58^{\prime} \mathrm{N}$, long $116^{\circ} 51^{\prime} \mathrm{W}$.

Land classification: Toiyabe National Forest.

Area: $2 \mathrm{~km}^{2}$.

Accessibility: Light-duty improved State Road 82 passes along the west side of Monitor Valley, approximately $9 \mathrm{~km}$ east of the outcrop.

Remoteness: Austin (population 300) in Lander County is the nearest town, lying about $62 \mathrm{~km}$ northwest of the outcrop.

Geologic setting: A potassium-argon age of biotite from a sample of medium-grained granodiorite is $154 \pm 3$ m.y.(Silberman and McKee, 1971). The stock intrudes transitional assemblage rocks primarily composed of Ordovician limestone, dolomite, shale, and quartzite of the Pogonip Group.

Hydrologic setting: The Northumberland pluton is located within the Monitor Valley groundwater system and drainage basin. The nearest significant discharge area is about $10 \mathrm{~km}$ to the east, but ranch wells may intercept some of the flow closer to the pluton. The water is used for livestock and ranch facilities.

Aeromagnetic expression: No distinct anomaly is associated with the plutonic rock exposures. Mining activities: Two barite mines are in operation less than $10 \mathrm{~km}$ north and south of the outcrop. Disseminated gold deposits are associated with the intrusive.

Selected reference: Silberman and McKee, 1971. 
General location: Two large exposures of granitic rocks, within $5 \mathrm{~km}$ of one another, occur near the southern end of the Toquima Range.

Coordinates: Belmont pluton (6a)--1at $38^{\circ} 39^{\prime} \mathrm{N}$, , long $117^{\circ} \mathrm{W}$. Manhattan pluton (6b) --1 at $38^{\circ} 29^{\prime}$ N., long $117^{\circ} 04^{\prime} \mathrm{W}$.

Land classification: Toiyabe National Forest.

Area: The northern exposure (Belmont pluton) and southern exposure (Manhattan pluton) are $148 \mathrm{~km}^{2}$ and $62 \mathrm{~km}^{2}$, respectively.

Accessibility: State Highway $8 \mathrm{~A}$ passes within $5 \mathrm{~km}$ of the Belmont pluton and 1ight-duty State Highway 82 follows Ralston Valley $2.5 \mathrm{~km}$ west of the Manhattan pluton and crosses the Belmont pluton near Belmont. Light-duty State Highway 69 traverses the range and ends at Manhattan where unimproved mining roads extend eastward and intersect Highway 82 in Ralston Valley.

Remoteness: The mining towns of Round Mountain (population 100) and Belmont (population 10?)

lie near the Belmont pluton outcrop boundaries. The town of Manhattan (population 30) lies $4 \mathrm{~km}$ north of the Manhattan pluton.

Geologic setting: The Belmont pluton (6a) is composed principally of granite, granitic porphyry, and porphyritic quartz monzonite. An age determination of biotite from a sample of porphyritic quartz-monzonite is $79.6-2.0$ m.y. (Krueger and Schilling, 1971). A younger segment of the granitic mass cuts the Belmont pluton in half. This segment, referred to as the "Toquima" pluton has been described as a quartz-monzonite porphyry having an age of $76.4_{-2}^{+} .8 \mathrm{~m} . y$. (Krueger and Schilling, 1971). The Belmont pluton intrudes undivided shale and limestone (locally metamorphosed to slate and marble) of Ordovician age and the Cambrian Gold Hill Formation composed of quartzite and subordinate shale and limestone. Paleozoic rocks are partly exposed along the northern, eastern, and western borders but are overlain by 01 igocene tuffs to the south and Miocene tuffs to the north.

The granitic mass south of Manhattan ${ }^{\alpha}(6 \mathrm{~b})$ is in contact primarily with a sequence of undivided shales and limestones of Ordovician age, which includes the Palmetto Formation. Alluvial fill of Ralston Valley covers the eastern margin of the pluton

Although numerous normal faults have been mapped within the Paleozoic sedimentary rocks and Tertiary volcanic rocks, only two have been shown to extend into the Belmont pluton (p1. 4). The most structurally disturbed area within the Paleozoic sequence underlies the Manhattan district where the Gold Hill Formation has been thrust over Ordovician shales and limestones.

Hydrologic setting: Both the Belmont and Manhattan plutons are in the Clayton Valley groundwater system.

Runoff from the Belmont pluton drains to Big Smoky, Monitor, and Ralston Valleys. Runoff from the Manhattan pluton drains to Big Smoky and Ralston Valleys. 
NN-6a and 6b. BELMONT AND MANHATTAN--Continued

Hydrologic setting:--Continued

The nearest discharge to the center of the Belmont pluton is $10 \mathrm{~km}$ southeast at Belmont. The nearest discharge to the center of the Manhattan pluton is $19 \mathrm{~km}$ westward.

Ground water is used in the area for domestic and livestock purposes.

Aeromagnetic expression: (6a) Although no single, well-defined anomaly is associated with the large exposed mass, presumably because of its silicic composition, the rocks appear to generally contribute to a broad lowamplitude magnetic plateau.

(6b) A high-amplitude positive anomaly extends over the western half of the outcrop area. Because much of the eastern gradient of the anomaly conforms to the geometry of the exposed mass, the granitic rocks are inferred to serve as the anomaly source. If so, the western edge of the main mass of granitic rocks occurs in the subsurface about $5 \mathrm{~km}$ west of the exposed western contact. The maximum areal extent of the source is estimated to be $100 \mathrm{~km}^{2}$.

Mining activity: One silver mine and six gold mines are active within the Round Mountain, Manhattan, and Belmont mining districts. Mineralization occurred in association.with Jurassic or Cretaceous granitic intrusives and with Tertiary lavas. The principal production has come from the younger gold deposits of Manhattan and Round Mountain.

Comments: As part of the Central Nevada Test Area exploratory program, drill hole UE-1 was drilled in granite approximately $13 \mathrm{~km}$ northeast of Manhattan and about $6 \mathrm{~km}$ west of Belmont. The total depth of the drill hole was $610 \mathrm{~m}$.

Selected references: Ferguson, 1924; Ferguson and Cathcart, 1954; Krueger and Schi11ing, 1971. 
General location: $10 \mathrm{~km}$ north of Tonopah in the San Antonio Mountains.

Coordinates: lat $38^{\circ} 10^{\prime} \mathrm{N}$., long $117^{\circ} 13^{\prime} \mathrm{W}$.

Land classification: Public domain.

Area: $5 \mathrm{~km}^{2}$.

Accessibility: Interstate Highway 951 ies $8 \mathrm{~km}$ to the southwest, State Highway 8 A 1 ies $8 \mathrm{~km}$ to the east, and State Highway 89 lies $9 \mathrm{~km}$ to the west of the outcrop.

Remoteness: The outcrop lies approximately $10 \mathrm{~km}$ north of Tonopah (population 1,716).

Geologic setting: The diorite, of Mesozoic or Tertiary age, intrudes undivided Ordovician shales and limestone that are locally metamorphosed to slate and marble. Along its northeastern and southern boundaries, the pluton is unconformably overlain mainly by welded ash-flow tuff, which commonly is altered and locally mineralized. Extensive basalt and andesite flows of Tertiary age occur throughout the San Antonio Mountains.

Hydrologic setting: The Black Mountain pluton is located in the Clayton Valley ground-water system and Big Smoky Valley drainage basin. The nearest discharge area is the Clayton Valley playa, $42 \mathrm{~km}$ southwest. The water is used mainly for industrial purposes.

Aeromagnetic expression: The exposed rocks occur at the northern extremity of a high-amplitude positive anomaly that is associated with a variety of extrusive rocks to the south.

Comment: Numerous inactive mines exist throughout the Tonopah mining district. 
NN-8. TOIYABE RANGE

General location: Northwest of the town of Round Mountain along the eastern flank of the

Toiyabe Range. The outcrops extend along a belt, $30 \mathrm{~km}$ long, from the northern Nye County border southward to the North Twin River.

Coordinates: 1at $39^{\circ} 02^{\prime} \mathrm{N}$. , long $117^{\circ} 13^{\prime} \mathrm{W}$. (midpoint within the belt).

Land classification: The five outcrops lie within Toiyabe National Forest. A small segment of land $\left(1 \mathrm{~km}^{2}\right)$ is designated as Indian Trust Allotments along the eastern margin of the southernmost exposure.

Area: Beginning with the northernmost and moving southward, the crystalline exposures encompass $30,13,1,10$, and $10 \mathrm{~km}^{2}$, respectively.

Accessibility: All intrusives are within $5 \mathrm{~km}$ west of State Highway $8 \mathrm{~A}$, which passes along the west side of Big Smoky Valley.

Remoteness: The town of Austin (population 300, Lander County) lies approximately $37 \mathrm{~km}$ from the northernmost outcrop and Round Mountain (population 100) is $26 \mathrm{~km}$ southeast of the southernmost pluton.

Geologic setting: The northernmost outcrop in this belt of intrusives is referred to in the literature as the "Aiken Creek pluton." Like other plutons in the region, its contacts with Paleozoic strata are sharp, steep, and, in most places, discordant. The main rock types range from granodiorite to granite. No age dates were found for the other exposures within the belt but they have been mapped as Tertiary or Mesozoic/Cenozoic.

The Gold Hill Formation, composed chiefly of Cambrian quartzite with subordinate shale and limestone (locally metamorphosed to slate and marble), is the primary host rock of the three northern crystalline bodies. The southernmost intrusive is in contact with the Lower Triassic Pablo Formation, composed of altered andesitic flows, breccias, and chert, with minor conglomerate and limestone.

The major normal faults occurring in the country rock generally do not offset the intrusives, except for the Aiken Creek pluton, where the western part is downthrown to the west. Also, granite dikes and dikes of rhyolitic to basaltic composition extensively intrude the northernmost stock.

The eastern margins of the plutons are covered by and possibly faulted against alluvium along the eastern flank of the Toiyabe Range.

Hydrologic setting: These intrusives are principally in the Big Smoky Valley ground-water system, although some ground water might move westward into the Reese River Valley system. Surface runoff flows into Big Smoky Valley and Reese River Valley drainage basins. The nearest significant ground-water discharge is $7 \mathrm{~km}$ eastward; ranch wells in Big Smoky Valley nearer to the intrusives intercept some of the groundwater flow. Ground water is used in the area mainly for domestic and livestock purposes. 
NN-8. TOIYABE RANGE--Continued

Aeromagnetic expression: Although the northernmost and southernmost outcrop areas, mapped as Tertiary quartz monzonite and granodiorite, have only weak magnetic expression, the two central bodies, mapped as Cenozoic/Mesozoic quartz monzonite and granodiorite, are clearly associated with a regional, north-trending, high-amplitude, positive anomaly. The maximum areal extent of the buried source is about $50 \mathrm{~km}^{2}$.

Mining activity: Along the western margin of the southernmost outcrop, there is (1976) a tungsten mine in operation.

Comment: Faults have been mapped in the alluvium in Reese River Valley approximately $12 \mathrm{~km}$ west of the exposures.

Selected reference: Stewart and McKee, 1977. 
General location: Eastern flank of the Toiyabe Range approximately $14 \mathrm{~km}$ northwest of the town of Round Mountain and about $13 \mathrm{~km}$ south of the stocks described above as NN-8.

Coordinates: lat $38^{\circ} 46^{\prime} \mathrm{N}$, long $117^{\circ} 13^{\prime} \mathrm{W}$.

Land classification: Toiyabe National Forest.

Area: $7 \mathrm{~km}^{2}$.

Accessibility: Outcrop is easily accessible from Highway 8A, which passes within $1.6 \mathrm{~km}$ of the exposure.

Remoteness: Round Mountain lies approximately $14 \mathrm{~km}$ southeast of the exposure.

Geologic setting: The Tertiary quartz monzonite of the Broad Creek pluton intrudes the Palmetto Formation (Ordovician shale and limestone) to the south, the Pablo Formation (Early Triassic age; altered andesite, chert, minor conglomerate and limestone) to the west and the Darrough Felsite (Middle Tertiary) to the north. The eastern border is faulted against alluvium in Big Smoky Valley.

Hydrologic setting: The Broad Creek pluton is located within the Big Smoky Valley groundwater system and drainage basin. The nearest discharge area is $5 \mathrm{~km}$ to the northeast. Livestock and cattle ranches use this water.

Aeromagnetic expression: The northeast-trending mapped outline of granitic rocks is crossed at right angles by a northwest-trending positive anomaly having an unknown source. Because the granitic rocks are oriented nearly perpendicular to a steep magnetic gradient, the anomaly source rocks appear to be different from the exposed ones.

Comments: The Darrough Hot Springs are located along the west side of Big Smoky Valley approximately $4 \mathrm{~km}$ northeast of the exposure. 
NN-10a and 10b. UNION MINING DISTRICT

General location: Western flank of the Shoshone Mountains. The northernmost body is centered near Ione and the southernmost body occurs near the boundary of the district, approximately $3.4 \mathrm{~km}$ south of Spanish Canyon.

Coordinates: lat $38^{\circ} 57^{\prime} \mathrm{N}$, long $117^{\circ} 35^{\prime} \mathrm{W}$.; and lat $38^{\circ} 47^{\prime} \mathrm{N}$., long $117^{\circ} 37^{\prime} \mathrm{W}$.

Land classification: Most of the district lies within the Toiyabe National Forest except for a small area immediately surrounding the town of Ione.

Area: The outcrop near Ione is $1 \mathrm{~km}^{2}$ and the exposure south of Spanish Canyon is less than $1 \mathrm{~km}^{2}$.

Accessibility: A light-duty road with an unimproved surface passes along the middle of Ione valley to the town of Ione. The road passes within $10 \mathrm{~km}$ of the southern exposure.

Remoteness: Two small mining towns of Ione and Berlin are located along the western flank of the Shoshone Mountains. Gabbs (population 874) is approximately $30 \mathrm{~km}$ west of the outcrops.

Geologic setting: (10a) Along its northern and eastern boundaries, the pluton of Mesozoic age is in contact with the greenstone member of the Pablo Formation (Lower Triassic), composed of altered andesitic flows and volcanic breccias and subordinate clastic rocks. The southern border is faulted against the Grantsville (Middle Triassic), Luning (Upper Triassic), and Pablo Formations. The Grantsville Formation consists of siliceous conglomerates and sandy argillites and limestones with subordinate intercalated shales. The clastic member of the Luning Formation is composed of coarse- to fine-grained noncalcareous sediments.

Although the intrusive rock is chiefly quartz diorite, it grades in composition from diorite through quartz diorite to granodiorite.

(10b) The intrusive south of Spanish Canyon is a small exposure of quartzmonzonite porphyry of Mesozoic age that intrudes the Dunlap Formation (Lower Jurassic), which is composed of sandstone, siltstone, dolomitic limestone, and dolomite. The southern and eastern boundaries are overlapped by Tertiary volcanic rocks.

Numerous normal and preintrusive thrust faults exist within the Mesozoic strata and at places form contacts with the intrusives.

Hydrologic setting: The Union mining district is within the Clayton Valley ground-water system and Ione Valley drainage basin. The nearest major discharge area is about $62 \mathrm{~km}$ south in Big Smoky Valley. Wells and springs in Ione Valley nearer to the mining district might intercept some of the regional underflow of the ground-water system. Water is used in the area mainly for livestock. 
NN-10a and 10b. UNION MINING DISTRICT--Continued

Aeromagnetic expression: (10a) The exposure occurs at the southeastern margin of a regional northwest-trending positive anomaly but apparently is not a significant contributor to the feature. The anomaly may be caused by buried extrusive or intrusive rocks that are not necessarily continuous with the exposed rocks.

(10b) No well-defined anomaly is associated with the small outcrop.

Mining activity: Two gold mines are active within the Ione area,

Comments: Several faults have been mapped in the alluvium underlying Ione Valley $5 \mathrm{~km}$ west of Spanish Canyon.

Selected references: Silberling, 1959; Vitaliano, 1963 , 
General location: South of the Shoshone Mountains.

Coordinates: lat $38^{\circ} 31^{\prime} \mathrm{N}$, long $117^{\circ} 37^{\prime} \mathrm{W}$.

Land classification: Public domain.

Area: $2 \mathrm{~km}^{2}$ (cumulative).

Accessibility: State Highway 89, having an unimproved surface, passes along the eastern flank of Royston Hills approximately $1.6 \mathrm{~km}$ east of the outcrops.

Remoteness: The outcrops are approximately $48 \mathrm{~km}$ southeast of Gabbs (population 874 ) and $61 \mathrm{~km}$ northwest of Tonopah (population 1,716).

Geologic setting: The pluton in the Royston Hills consists of three exposures of diorite that intrude the Luning Formation (Upper Triassic) composed of limestone, dolomite, conglomerate, and shale to the north and south. Basalt and andesite flows of Tertiary age overlie the intrusive along the western boundary.

Hydrologic setting: The Royston Hills are located in the Clayton Valley ground-water system and Ione and Big Smoky Valleys basins. The nearest significant discharge area is $29 \mathrm{~km}$ eastward. The water is used for livestock and domestic purposes.

Aeromagnetic expression: No well-defined anomaly is associated with the main outcrops of granitic rock. Although it is likely that the major west-trending elongate positive anomaly just north of the main outcrop pattern is largely associated with andesitic and basaltic rocks covered by alluvium, the possibility of a buried granitic rock source cannot be dismissed. The maximum areal extent of the inferred source is estimated to be $25-50 \mathrm{~km}^{2}$.

Comments: The exposures are located near the Nevada seismic zone and are only about $20 \mathrm{~km}$ from the 1932 Cedar Mountain earthquake in Mineral County. 
NN-12a, 12b, and 12c. PARADISE RANGE

Three main intrusive bodies:

General location: (12a) North of Sherman Peak along the eastern edge of the Paradise Range, referred to as the Lodi Hills pluton.

Coordinates: lat $38^{\circ} 59^{\prime} \mathrm{N}$., long $117^{\circ} 44^{\prime} \mathrm{W}$.

Land classification: Toiyabe National Forest.

Area: $4 \mathrm{~km}^{2}$ (cumulative).

Accessibility: State Highway 91 traverses the Paradise Range just north of Gabbs, $9 \mathrm{~km}$ south of the main outcrop.

Remoteness: Nearest towns include Ione, $16 \mathrm{~km}$ east, and Gabbs (population 874), $18 \mathrm{~km}$ southwest.

Geologic setting: The largest exposure, composed of porphyritic granite, intrudes the Lower Triassic Greenstone member of the Pablo Formation, which is composed of metamorphosed volcanic breccias, tuffs, and lavas. Northern and southern boundaries are overlapped by Tertiary ash-flow tuffs and trachyandesites. Several Tertiary basalt and andesite flows occur in the eastern part of the range. This pluton includes two isolated outcrops mapped as dioritic rocks that intrude the Pablo. A granite sample taken from the isolated exposure northwest of the main body has been radiometrically dated as 46.9-2.0 m.y. (Krueger and Schilling, 1971).

Aeromagnetic expression: The exposed rocks occur at the southeastern margin of a generally northwest-trending high-amplitude positive anomaly. The anomaly has an unknown source but may be caused by similar rocks at depth to the northwest. The maximum areal extent of the inferred source is about $15 \mathrm{~km}^{2}$.

General location: (12b) Approximately $10 \mathrm{~km}$ north of Gabbs along the west side of Lodi Valley. Coordinates: lat $38^{\circ} 59^{\prime} \mathrm{N}$., long $117^{\circ} 53^{\prime} \mathrm{W}$.

Land classification: Public domain.

Area: Approximately $8 \mathrm{~km}^{2}$.

Accessibility: State Highway 23 passes about $5 \mathrm{~km}$ to the west of the pluton and an unimproved road passes along Lodi Valley $1.6 \mathrm{~km}$ to the east.

Remoteness: The town of Gabbs is located approximately $10 \mathrm{~km}$ south of the intrusive.

Geologic setting: This exposure is a Tertiary pluton that intrudes limestone, dolomite, and siltstone of the Luning Formation (Upper Triassic). To the northwest, Middle Triassic(?) quartzite, limestone, and altered volcanic rocks of the Excelsior Formation are thrust over the Luning Formation.

The intrusive is composed predominantly of porphyritic granite, and contains lesser amounts of diorite, fine-grained granite and granodiorite. Numerous granophyric dikes and sills occur throughout the exposure.

Aeromagnetic expression: The mapped rocks occur at the northern margin of a northeast-trending positive anomaly. The source of the anomaly is unknown but it may be plutonic rocks inasmuch as no other candidates appear at the surface. The maximum areal extent of the inferred source is $50 \mathrm{~km}^{2}$.

Mining activity: An active tungsten mine is located along the southern margin of the outcrop. 
General location: (12c) 1.6-12 km east and southeast of Gabbs in the Paradise Range. The large exposure southeast of Gabbs is referred to in the literature as the Gabbs pluton.

Coordinates: The outcrops are centrally located around lat $38^{\circ} 51^{\prime} \mathrm{N}$, , long $117^{\circ} 51^{\prime} \mathrm{W}$. Land classification: Toiyabe National Forest.

Area: $15 \mathrm{~km}^{2}$ (cumulative).

Accessibility: State Highway 23, passing through Gabbs, provides easy access to the western flank of Paradise Range. A few unimproved roads provide access to mining claims along the eastern flank.

Remoteness: The town of Gabbs (population 874) is 1.6-12 km west and northwest of the ourcrops. Geologic setting: Mesozoic and (or) Cenozoic granodiorite outcrops, which occur along the western flank of the range, intrude limestone, dolomite, and siltstone of Luning (Upper Triassic), Sunrise (Upper Triassic), and Gabbs (Lower Jurassic) Formations. Extensive hydrothermal alteration and silicification occur along or near the margins of the two westernmost outcrops and along the Paradise thrust fault, which is directly east of the large western exposure. These igneous bodies are commonly associated with granophyric dikes and sills. The granitic body just east of Gabbs has been dated at $11.3-1.2$ m.y. but this may reflect reheating due to the dike swarms (Krueger and Schilling, 1971). Igneous rocks along the eastern flank of the Paradise Range have been described as porphyritic granite and granodiorite of Mesozoic or Cenozoic age. The stocks generally intrude Mesozoic sedimentary rocks.

Aeromagnetic expression: The mapped rocks occur on the relatively gentle northern flank of a nearly circular high-amplitude positive anomaly. If the anomaly is caused by a southeastward extension of these in the subsurface, their areal extent may be $5-10 \mathrm{~km}^{2}$.

Hydrologic setting: (12a, 12b, and 12c) Although subdivided geologically into three intrusive masses, hydrologically, the intrusives can be divided into two areas. These are:

Northern area (12a and 12b)--Part of the Clayton Valley ground-water system and the Ione Valley drainage basin. The nearest major discharge area is approximately $67 \mathrm{~km}$ to the southeast; however, ranch wells in Ione Valley intercept some ground-water flow nearer to the area.

Southern area (12c)--Included in the Gabbs Valley ground-water system and drainage basin. The nearest major discharge area is the main playa in Gabbs Valley, $28 \mathrm{~km}$ northwest. Water in both areas is used for 1 ivestock purposes.

Mining activity: An active lithium mine is located about $3 \mathrm{~km}$ east of Gabbs.

Comment: A fault displacing the alluvium has been mapped along the western flank of the Paradise Range.

Selected references: Krueger and Schilling, 1971; Vitaliano, 1963; Vitaliano and Callaghan, 1963. 
NN-13. MONTE CHRISTO MOUNTAINS

General location: Near the extreme northwestern corner of northern Nye County.

Coordinates: lat $38^{\circ} 59^{\prime} \mathrm{N}$., long $118^{\circ} 9^{\prime} \mathrm{W}$.

Land classification: Public domain.

Area: $18 \mathrm{~km}^{2}$.

Accessibility: Southern Monte Christo Mountains lie approximately $13 \mathrm{~km}$ west of State Highway

23. Several improved mining roads traverse the area.

Remoteness: The nearest populated area is Gabbs, approximately $22 \mathrm{~km}$ to the southeast.

Geologic setting: These exposures of granitic rock are Mesozoic in age. In the north, the two in Nye County are altered volcanic rocks of the Middle Triassic(?) Excelsior(?) Formation. The eastern and southern boundaries are overlapped by Tertiary welded tuffs, rhyolite flows, plugs, and dikes, and Tertiary basalt and andesite flows. Within this area there is an isolated outcrop of quartz monzonite and granodiorite that intrudes the Excelsior Formation in Gabbs Valley in Mineral County.

Several normal faults cut the granitic body. A major fauit marks the granitealluvium boundary along the western flank of the largest exposure. A branch of this fault offsets the alluvium in the same area.

Hydrologic setting: The Monte Christo Mountains are within the Gabbs Valley ground-water and drainage systems. The nearest discharge area is $7 \mathrm{~km}$ west. The water is used for livestock purposes.

Aeromagnetic expression: The mapped rocks are clearly associated with an elliptical, northtrending, high-amplitude positive anomaly. The areal extent of the source is estimated to be about the same as that of the exposed rocks.

Comments: The outcrop lies within the tectonically active Churchill arc and Nevada seismic zone. 


\section{ESMERALDA COUNTY}

GEOLOGY

Esmeralda County is located in southwestern Nevada adjacent to the California border and consists of arcuate ranges and intervening valleys.

The rocks exposed in the county consist of sedimentary, igneous, and metamorphic rocks of late Precambrian to Holocene age. Precambrian and Cambrian rocks occur in the southern two-thirds of the county and are metamorphosed along the contact with igneous intrusives. Ordovician rocks are found throughout the county, but Silurian, Devonian, and Pennsylvanian rocks are absent in the county; Permian strata are sparse.

Mesozoic sedimentary rocks occur in the northern part of the county. Granitic rocks of Jurassic and younger age are present throughout the county. Because of the lithologic similarity to and spatial relation of the granitic rocks of the county with those of the Sierra Nevada, Albers and Stewart (1972) suggested that the granitic bodies (fig. 8) are probably a continuation of the Sierra Nevada batholith.

Tertiary rocks include tuffs, lava flows, volcanic breccia, and sedimentary rocks. The volcanic rocks range in composition from rhyolite to basait and represent various periods of volcanic activity.

A zone approximately $482 \mathrm{~km}$ long and 80-161 km wide (A1bers and Stewart, 1972) forms a transition between the northwest-trending Sierra Nevada block to the west and the northnortheast-trending ranges of the Great Basin province to the east. One of the major structures in the county consists of an arcuate bend called an orocline that is well developed in the Silver Peak-Palmetto-Montezuma Range, and results from bending of the crust (Albers, 1967). This type of arcuate structure is present in other parts of the county but not as we11 developed. This arcuate shape, convex to the south, suggests drag caused by right-lateral shearing (Albers and Stewart, 1972). Right-lateral strike-slip faults are present in the county and include the following: (1) Death Valley-Furnace Creek Fault Zone (pl. 4). The fault zone has apparent right-lateral movement, with a separation of at least $29 \mathrm{~km}$ within the county (Albers and Stewart, 1972). (2) Soda Spring Valley Fault, mainly in Mineral County but extends into Esmeralda County, with a separation of at least $13 \mathrm{~km}$. (3) A fault in the Cedar Mountains, site of an earthquake in 1932, considered to be part of a major fault zone that forms a disrupted zone $805 \mathrm{~km}$ long called the Walker Lane (pl. 4) (Locke and others, 1940).

Thrust faults are very common in the pre-Tertiary rocks, where at 1east 50 percent of the contacts between pre-Tertiary rocks are thrusts (A1bers and Stewart, 1972). Albers and Stewart (1972) suggested that the thrusts formed largely in conjunction with development of the oroclinal structures and the intrusion of the quartz-monzonite plutons.

High-angle normal faults of pre-Tertiary and Tertiary age are very common and cut the older structures.

The county is within the Nevada seismic zone and is seismically very active. A high concentration of epicenters (pl.5) is located in the Columbus Salt Marsh area near Coaldale.

The geologic data were extracted and summarized from the following:

Albers, 1967; and Albers and Stewart, 1972. 


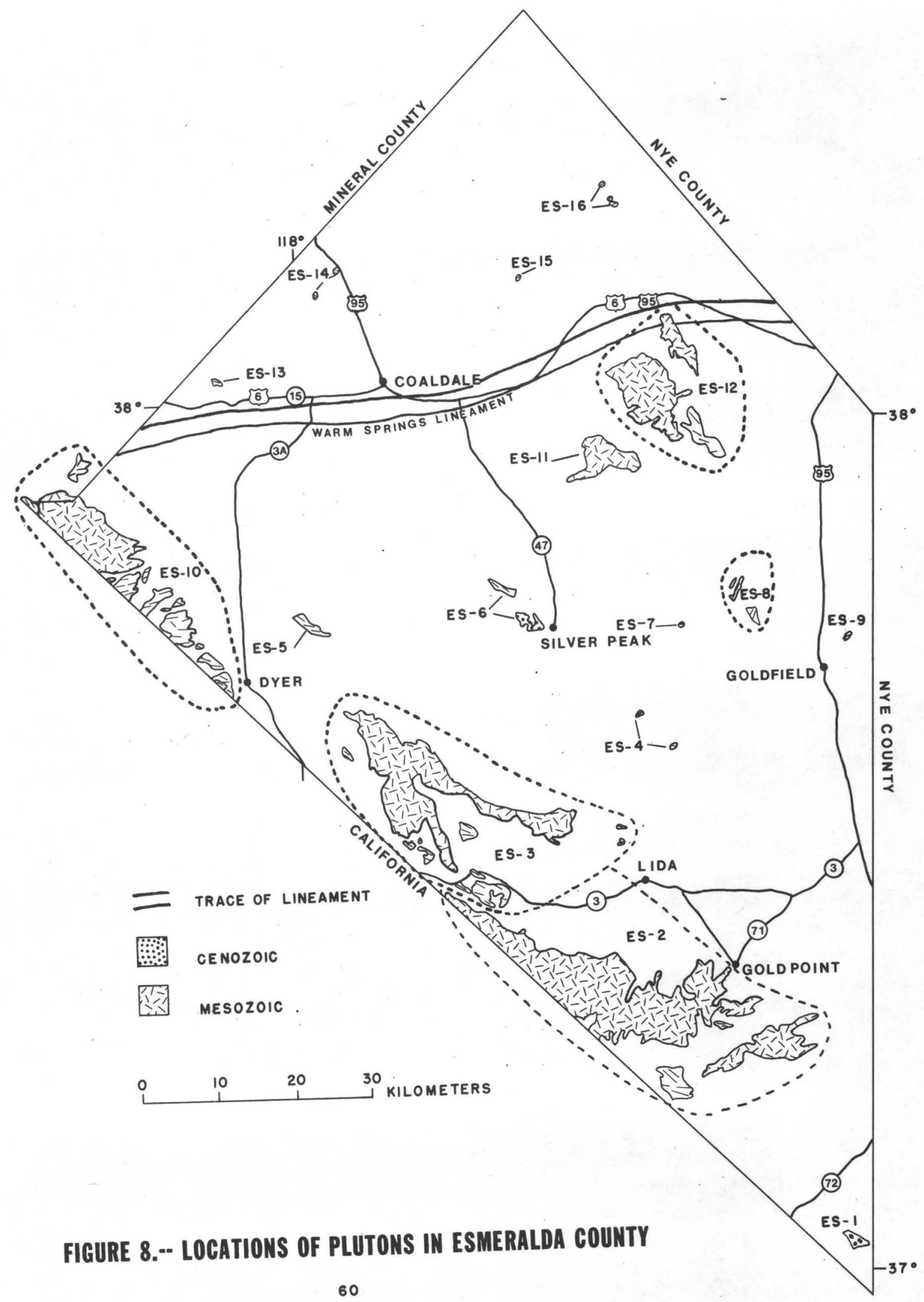


The Big Smoky Valley drainage basin terminates in the large playa east of Coaldale, in north-central Esmeralda County. Grapevine Canyon and Oriental Wash drain into Death Valley, both small areas in southern Esmeralda County. The remaining parts of Esmeralda County are drained centripetally into dominantly discharging (wet) playas and marshes within the county and adjacent areas.

The major sources of runoff and recharge are the White Mountains and the Silver Peak Range-Palmetto Mountains chain. Minor sources of recharge include the Grapevine and Sylvania Mountains, along the California State line and from Lone Mountain and the Montezuma Range.

The Clayton Valley ground-water system, carrying ground water from a large area to the north and east, terminates in Clayton Valley. Columbus Salt Marsh,in northern Esmeralda County, is the terminal discharge area for a moderately large ground-water system that extends into Mineral County. The Fish Lake Valley, dominantly closed ground-water system, feeds a minor amount of water into Columbus Salt Marsh. The Sarcobatus Flat ground-water system features southwesterly ground-water movement through the southernmost part of the county, with overflow into Death Valley via the Grapevine Canyon area.

The hydrology of Esmeralda County was taken mainly from the following references:

Rush,1968a; Rush and Katzer, 1973; and Rush and Schroer, 1970. 
ES-1. GRAPEVINE MOUNTAIN

Location: Northeastern flank of the Grapevine Mountains.

Coordinates: lat $37^{\circ} 02^{\prime} \mathrm{N}$., long $117^{\circ} 07^{\prime} \mathrm{W}$.

Land classification: Public domain in area of outcrop, and $0.5 \mathrm{~km}$ from the northern boundary of Death Valley National Monument.

Area: $4 \mathrm{~km}^{2}$.

Accessibility: $6 \mathrm{~km}$ southwest of State Highway 72 and $14 \mathrm{~km}$ northeast of California State Highway 190.

Remoteness: $40 \mathrm{~km}$ northwest of Beatty (in Nye County, population 900) and $37 \mathrm{~km}$ southeast of Gold Point (population 25).

Geologic setting: The pluton occurs in the Grapevine Mountains and consists of monzonite and diorite of Tertiary age. The Nopah Formation composed of dolomite of Cambrian age, shales of Mississippian age, and the Pogonip Group made up of limestones and shales of Ordovician age occur near the pluton and are probably intruded by the granitic body in the subsurface. Dacite lava flows and the Ammonia Tanks Member of Timber Mountain Tuff (both of Tertiary age) overlie the pluton unconformably.

A thrust fault located $4 \mathrm{~km}$ south of the pluton displaces the Paleozoic rocks. A northwest-trending high-angle normal fault cuts the pluton.

Hydrologic setting: The pluton is in the Death Valley ground-water system and the Grapevine Canyon drainage basin. The nearest discharge is in Grapevine Canyon at Scotty's Castle, Calif., $13 \mathrm{~km}$ west. The water is used for domestic supply.

Aeromagnetic expression: The granitic rocks occur at the northern steep gradient of a high-amplitude positive anomaly that may be entirely caused by the plutonic rock. However, anomalies in areas immediately adjacent to the pluton appear to be generated by ash-flow tuffs and related extrusive rocks.

Comment: The pluton is located $2 \mathrm{~km}$ from the California border, $15 \mathrm{~km}$ southeast of the Death Valley-Furnace Creek Fault Zone, and within the Nevada seismic zone. 


\section{ES-2. SYLVANIA}

General location: The pluton occurs in the Sylvania Mountains, part of the Last Chance

Range, and extends southeastward to Slate Ridge and Gold Mountain.

Coordinates: lat $37^{\circ} 19^{\prime} \mathrm{N} .$, long $117^{\circ} 31^{\prime} \mathrm{W}$.

Land classification: Predominantly public domain, with some private land in the Sylvania Mountains area and patented mining claims in the Gold Mountain

Area: $244 \mathrm{~km}^{2}$ (cumulative). and Slate Ridge area.

Accessibility: Approximately $2 \mathrm{~km}$ south of State Highway 3 from the northwest exposure of the pluton, approximately $1 \mathrm{~km}$ southwest of State Highway 71 from the northeast exposure of the pluton. Dirt roads common throughout the area.

Remoteness: $47 \mathrm{~km}$ southwest of Goldfield (population 185) and $12 \mathrm{~km}$ south of Lida.

Geologic setting: The pluton is composed of Jurassic quartz monzonite and intrudes the Precambrian Wyman Formation, which is composed of siltstone and limestone, and is overlain unconformably in the southeast exposure by the Ammonia Tanks Member of Timber Mountain Tuff (Tertiary). Other rock units in the area include the Precambrian Reed Dolomite and Deep Spring Formation and the Precambrian and Cambrian Campito Formation; there is also a basalt flow of Tertiary-Quaternary age. The pluton has been dated as $149 \pm 6$, $153 \pm 5$, and $155 \pm 6$ m.y. (Albers and Stewart, 1972). The Sylvania pluton forms a range that is concentric to the Silver Peak-Palmetto-Montezuma orocline and probably is part of the structure. High-angle norma? faults parallel the mountain range, cutting the pluton.

Hydrologic setting: The pluton is in the Death Valley ground-water system and drainage basin. The nearest discharge is $18 \mathrm{~km}$ south at Sand Spring, and the water is used by game and an occasional tourist.

Aeromagnetic expression: The granitic rock terrane has a highly complex magnetic signature. A regional northwest-trending high-amplitude negative anomaly covers the western two-thirds of the main mass and a more localized, lower amplitude, positive anomaly covers the eastern third. Elongate east- to northeast-trending high-amplitude positive anomalies are associated with much of the smaller plutonic rock masses to the south. The positive anomalies form an elliptical ring that conforms approximately with the outcrop pattern of the two southern bodies and with the eastern third of the main body. The negative anomaly is inferred to be caused by a northwest-trending belt of basalts that presumably have high-intensity, reversely polarized, total magnetizations. The maximum areal extent of the inferred sources of positive anomalies is approximately the same as that of the exposed rocks. 
ES-2.--SYLVANIA---Continued

Mining activity: Lead, silver, and gold mining activity occurs within the pluton.

Comment: The pluton lies along the California-Nevada border, is approximately $5 \mathrm{~km}$ north of the Death Valley-Furnace Creek fault zone, and occurs within the Nevada seismic zone.

Selected reference: Albers and Stewart, 1972. 


\section{ES-3. PALMETTO}

General location: Southern part of the Silver Peak Range, western half of Palmetto Mountains, in the Palmetto Wash area.

Coordinates: lat $37^{\circ} 34^{\prime} \mathrm{N}$., long $117^{\circ} 51^{\prime} \mathrm{W}$.

Land classification: Predominantly public domain, with some private lands and patented

Area: $170 \mathrm{~km}^{2}$ (cumulative). mining claims.

Accessibility: Approximately $5 \mathrm{~km}$ east of State Highway $3 \mathrm{~A}$. State Highway 3 intersects the southern exposure of the pluton.

Remoteness: $37 \mathrm{~km}$ southwest of Goldfield (population 185) and $12 \mathrm{~km}$ northwest of Lida. Geologic setting: The pluton is composed of quartz monzonite and intrudes the Lower Cambrian Harkless Formation composed of siltstone; Middle and Upper Cambrian Emigrant Formation, composed of claystone and limestone; Ordovician Palmetto Formation, which includes shale, chert, limestone, and quartzite. Other rock units are the Lower Cambrian Poleta Formation, Tertiary volcanic rocks, and Tertiary-Quaternary basalt flows. The pluton has been dated as $129 \pm 6$ and $188 \pm 7$ m.y. (A1bers and Stewart, 1972).

Thrust faults and high-angle faults are the predominant structures within che area. The pluton has also been affected by high-angle normal faulting. The pluton makes up the eastward-trending segment of the Silver Peak-Palmetto-Montezuma orocline.

Hydrologic setting: The pluton is in Fish Lake Valley ground-water system and drainage basin. The nearest discharge is $13 \mathrm{~km}$ southwestward at Oasis, Calif. The water is used in the area mainly for irrigation, domestic, and livestock purposes.

Aeromagnetic expression: A northwest-trending belt of high-amplitude positive anomalies is clearly associated with the granitic rocks. Lower amplitude negative anomalies are associated with small outcrops of basalt, presumably possessing reversed total magnetization. Broad positive anomalies west of the northwestern extremity of the main mass and south of the southeastern extremity of the main mass may reflect buried tracts of plutonic rocks having maximum areal extents of $25 \mathrm{~km}^{2}$ and $10 \mathrm{~km}^{2}$, respectively.

Mining activity: Tungsten and gold mining activity within or very near the pluton.

Comments: Mining activity occurs within or very near the pluton. The pluton is located approximately $10 \mathrm{~km}$ north of the Death Valley-Furnace Creek Fault Zone, and is within the Nevada seismic zone.

Selected reference: Albers and Stewart, 1972. 
General location: Two adjacent areas--southern Clayton Ridge and west flank of the Montezuma Range.

Coordinates: lat $37^{\circ} 39^{\prime} \mathrm{N}$., long $117^{\circ} 28^{\prime} \mathrm{W}$.

Land classification: Public domain.

Area: $1 \mathrm{~km}^{2}$ (cumulative).

Accessibility: $16 \mathrm{~km}$ southeast of State Highway 47.

Remoteness: $24 \mathrm{~km}$ southwest of Goldfield (population 185).

Geologic setting: The pluton is Mesozoic quartz monzonite that intrudes the Precambrian and Cambrian Campito Formation, composed of metamorphosed siltstone and quartzite, and is overlain unconformably by ash-flow tuffs of the Tertiary Esmeralda Formation. The Clayton Ridge pluton is probably connected with the Sylvania pluton in the subsurface.

The Clayton Ridge is one of the eastern limbs of the Silver Peak-PalmettoMontezuma orocline. Albers and Stewart (1972) inferred that Clayton Ridge is separated from Clayton Valley by a high-angle normal fault, having movement that both predates and postdates the Tertiary rocks. Precambrian and Cambrian rocks in the area have been affected by thrust and high-angle normal faulting.

Hydrologic setting: The pluton is in the Clayton Valley ground-water system and drainage basin. The nearest discharge point is $15 \mathrm{~km}$ westward in the southern Clayton Valley playa. The water is unused.

Aeromagnetic expression: A low-amplitude positive anomaly flexure is associated with the northern rock outcrop. The southern outcrop occurs on the northern steep gradient of a high-amplitude positive anomaly inferred to be caused by a variety of intrusive and extrusive rocks.

Mining activity: Gold and silver mining activity approximately $8 \mathrm{~km}$ south of the granitic intrusive.

Comment: The pluton occurs near mining activity and approximately $20 \mathrm{~km}$ northeast of the Nevada seismic zone.

Selected reference: Albers and Stewart, 1972. 
ES-5. DYER

General location: Northwestern flank of the Silver Peak Range.

Coordinates: lat $37^{\circ} 45^{\prime} \mathrm{N}$., long 118 $00^{\prime} \mathrm{W}$.

Land classification: Public domain.

Area: $5 \mathrm{~km}^{2}$.

Accessibility: Approximately $6 \mathrm{~km}$ east of State Highway $3 \mathrm{~A}$, and $0.5 \mathrm{~km}$ east of an improved surface road that connects with State Highway $3 \mathrm{~A}$.

Remoteness: Approximately $55 \mathrm{~km}$ west of Goldfield (population 185) and approximately $32 \mathrm{~km}$ southwest of Coaldale (population 35).

Geologic setting: The pluton is Jurassic quartz monzonite that intrudes the Lower Cambrian Harkless Formation of metamorphosed siltstone and quartzite.

The structure in the area consists of normal and thrust faults. A normal fault, approximately $8 \mathrm{~km}$ southwest of the pluton, displaces the alluvium.

Hydrologic setting: The pluton is in Fish Lake Valley ground-water system and drainage basin.

The nearest discharge point is $3 \mathrm{~km}$ west at the edge of the valley.

Water is used here for livestock, irrigation, and domestic purposes.

Aeromagnetic expression: The exposed rocks coincide with the nose of a regional northwesttrending high-amplitude positive anomaly. The source of the major anomaly is unknown but may be similar plutonic rocks at depth. The maximum areal extent of the source of the large anomaly is about $100 \mathrm{~km}^{2}$.

Comment: The intrusive body occurs approximately $2 \mathrm{~km}$ northeast of the Nevada seismic zone and is approximately $7 \mathrm{~km}$ northeast of the Death Valley-Furnace Creek Fault Zone. 


\section{ES-6. MINERAL RIDGE}

General location: East-central part of Mineral Ridge.

Coordinates: lat $37^{\circ} 45^{\prime} \mathrm{N}$., long $117^{\circ} 39^{\prime} \mathrm{W}$.

Land classification: Public domain, with some patented mining claims.

Area: $7 \mathrm{~km}^{2}$ (cumulative).

Accessibility: Approximately $2 \mathrm{~km}$ west of State Highway 47 and approximately $25 \mathrm{~km}$ south of

U.S. Highway 6 and 95 .

Remoteness: $38 \mathrm{~km}$ west-northwest of Goldfield (population 185).

Geologic setting: The granitic rocks at Mineral Ridge a re composed of two plutons; one is Mesozoic and the other is Cenozoic in age. The two plutons will be considered and discussed as one pluton.

The pluton is quartz monzonite and intrudes the Precambrian Wyman Formation composed of siltstone and limestone. Other rock units in the area include the Precambrian Reed Dolomite and Deep Spring Formation, the Precambrian and Cambrian Campito, and the Cambrian Poleta and Harkless Formations. Part of the pluton has been dated as $42 \pm 2$ and $51 \pm 2$ m.y. (Albers and Stewart, 1972). The structure in the area consists of thrusts in the Precambrian and Cambrian rocks. The pluton has been displaced by high-angle normal faults.

Hydrologic setting: The pluton is in the Clayton Valley ground-water system and drainage basin. The nearest discharge point is $5 \mathrm{~km}$ east and the water is used for industrial purposes.

Aeromagnetic expression: Both outcrop areas are characterized by low magnetic relief. Mining activity: Lithium operation $1 \mathrm{~km}$ east of the intrusive.

Comment: Granitic rock outcrop is $1 \mathrm{~km}$ west of lithium operation and approximately $25 \mathrm{~km}$ northeast of the Nevada seismic zone. 
General location: Pluton occurs between the Paymaster Ridge and Clayton Ridge.

Coordinates: lat $37^{\circ} 45^{\prime} \mathrm{N}$, , long $117^{\circ} 28^{\prime} \mathrm{W}$.

Land classification: Public domain.

Area: Less than $1.0 \mathrm{~km}^{2}$.

Accessibility: $16 \mathrm{~km}$ east of State Highway 47 and approximately $17 \mathrm{~km}$ west of U.S. Highway 95.

Remoteness: Approximately $18 \mathrm{~km}$ west-northwest of Goldfield (population 185).

Geologic setting: The intrusive is quartz monzonite that intrudes the Cambrian Poleta Formation, which is composed of carbonates, limestone, and quartzite and the Precambrian and Cambrian Campito Formation, which is composed of siltstone and quartzite. Other rock units in the area include the Lower Cambrian Mule Spring Limestone.

The structure of the area consists of thrust faults and high-angle normal faults. The pluton is located within the Walker Lane Fault Zone.

Hydrologic setting: The pluton is in the Clayton Valley ground-water system and drainage basin. The nearest discharge point is $9 \mathrm{~km}$ west, where the water is used for industrial purposes.

Aeromagnetic expression: The small outcrop occurs on the northern flank of a regional highamplitude positive anomaly associated with a variety of intrusive and extrusive rocks.

Comment: The pluton is located within the Walker Lane Fault Zone and is approximately $36 \mathrm{~km}$ northeast of the Nevada seismic zone. 


\section{ES-8. MONTEZUMA}

General location: Exposures of the intrusive are located in the northwestern flank of Montezuma Range and the southern Paymaster Ridge.

Coordinates: lat $37^{\circ} 45^{\prime} \mathrm{N}$., long $117^{\circ} 17^{\prime} \mathrm{W}$.

Land classification: Predominantly public domain, with some patented mining claims.

Area: $6 \mathrm{~km}^{2}$ (cumulative).

Accessibility: $8 \mathrm{~km}$ west of U.S. Highway 95.

Remoteness: $10 \mathrm{~km}$ northwest of Goldfield (population 185).

Geologic setting: The pluton is quartz monzonite and intrudes the Lower Cambrian Harkless Formation composed of siltstone, and the Ordovician Palmetto Formation composed of shale, chert, limestone, and quartzite. Other rock units in the area include the Precambrian and Cambrian Campito and Cambrian Poleta Formations, Tertiary volcanic rocks, and a basalt flow of TertiaryQuaternary age.

The Montezuma Range forms the eastern limb of the Silver Peak-PalmettoMontezuma Range orocline. Thrust faults within the Cambrian rocks are the dominant structures in the area. The pluton is located within the Walker Lane Fault Zone.

Hydrologic setting: The pluton is in the Clayton Valley ground-water system and drainage basin. The nearest discharge is $12 \mathrm{~km}$ westward where the water is used for industrial purposes.

Aeromagnetic expression: The short-wavelength magnetic anomalies in this area are largely attributable to basaltic rocks. The granitic rocks appear to have no pronounced magnetic signature.

Comment: The pluton is within the Walker Lane Fault Zone and is approximately $40 \mathrm{~km}$ northeast of the Nevada seismic zone. 
ES-9. GOLDFIELD HILLS

General location: Northwest Goldfield Hills.

Coordinates: lat $37^{\circ} 44^{\prime}$ N., long $117^{\circ} 08^{\prime} \mathrm{W}$.

Land classification: Patented mining claims.

Area: $1 \mathrm{~km}^{2}$ (cumulative).

Accessibility: $1 \mathrm{~km}$ east of U.S. Highway 95.

Remoteness: $3 \mathrm{~km}$ northeast of Goldfield (population 185).

Geologic setting: The pluton is quartz monzonite that is overlain unconformably by Tertiary volcanic rocks. The Goldfield Hills are the eastern limb of the Silver Peak-Palmetto-Montezuma orocline, where the structure of the area consists of northeast-trending high-angle normal faults. The area is within the Walker Lane Fault Zone.

Hydrologic setting: The pluton is in the Clayton Valley ground-water system and Alkali Spring Valley drainage basin. The nearest discharge is $29 \mathrm{~km}$ west, where the water is used for industrial purposes.

Aeromagnetic expression: The small outcrop occurs on the steep northwestern flank of a highamplitude positive anomaly largely associated with ash-flow tuffs and related extrusive rocks.

Comment: The intrusive is located within the Walker Lane Fault Zone and is approximately $45 \mathrm{~km}$ northeast of the Nevada seismic zone. 
ES-10. INYO BATHOLITH

General location: Northeast flank of the White Mountains.

Coordinates: lat $37^{\circ} 51^{\prime}$ N., long $118^{\circ} 21^{\prime} \mathrm{W}$.

Land classification: Inyo National Boundary Peak Forest.

Area: $103 \mathrm{~km}^{2}$ (cumulative).

Accessibility: $18 \mathrm{~km}$ southeast of U.S. Highway 6 and $2 \mathrm{~km}$ west of State Highway 3 A.

Remoteness: Approximately $50 \mathrm{~km}$ northeast of Bishop (population 3,498), Calif. Other minor

villages include: Dyer (population 10), $1 \mathrm{~km}$ northeast of easternmost

exposure; Benton, Calif., approximate?y $9 \mathrm{~km}$ to the southwest; and Coaldale (population 35), approximately $36 \mathrm{~km}$ to the northeast.

Geologic setting: The batholith of Jurassic and Creiaceous age is composed of quartz mon-

zonite and contains inclusions and pendants of Precambrian and Paleozoic rocks that have been metamorphosed. The batholith has intruded the following: Precambrian Wyman Formation, composed of siltstone and limestone, and the Reed Dolomite; Cambrian Harkless Formation, composed of siltstone; and the Ordovician Palmetto Formation, composed of shale, chert, limestones, and quartzite. Tertiary volcanic rocks include quartz-latite lava flows, nonwelded ash flows, and a basalt flow of Tertiary-Quaternary age.

A series of fault scarps in alluvium are present along the eastern edge of the batholith where the Death Valley-Furnace Creek Fault Zone has been projected. The Paleozoic and Precambrian rocks have been displaced by thrust faults.

Hydrologic setting: The batholith is in the Fish Lake Valley ground-water system and drainage basin. The nearest discharge is $19 \mathrm{~km}$ east and the water is used in the valley for domestic and irrigation purposes.

Aeromagnetic expression: The batholithic massif has a highly complex magnetic signature, although almost all well-defined gradients have northwest trends. Much of the granitic rock terrane is characterized by highamplitude anomalies, although the entire region has only moderate magnetic relief. Negative anomalies may represent polarization lows at the northeastern margins of the plutonic rock exposures.

Comments: The batholith lies along the California-Nevada border, within the Nevada seismic zone. Fault scarps, present in alluvium along the eastern edge of the batholith, probably coincide with the Death Valley-Furnace Creek Fault Zone. 
ES-11. WEEPAH

General location: Northwestern Weepah Hills.

Coordinates: lat $37^{\circ} 56^{\prime} \mathrm{N}$., Tong $117^{\circ} 30^{\prime} \mathrm{W}$.

Land classification: Public domain.

Area: $22 \mathrm{~km}^{2}$.

Accessibility: $10 \mathrm{~km}$ southeast of U.S. Highway 6 and 95 .

Remoteness: $35 \mathrm{~km}$ northwest of Goldfield and $27 \mathrm{~km}$ southwest of Tonopah (in Nye County, population 1,716).

Geologic setting: The pluton is quartz monzonite and intrudes the Precambrian Wyman Formation, which includes siltstone and limestone, and the Reed Dolomite; and the Precambrian and Cambrian Campito Formation, composed of siltstone and quartzite. The structure in the area consists of thrust and high-angle normal faults. The pluton is located within the Walker Lane Fault Zone.

Hydrologic setting: The pluton is in the Clayton Valley ground-water system and Clayton Valley and Big Smoky Valley drainage basins. The nearest discharge is $13 \mathrm{~km}$ south where the water is used industrially.

Aeromagnetic expression: A high-amplitude positive anomaly is clearly associated with the pluton, the areal extent of the anomaly source is estimated to be about the same as that of the exposed granitic rocks. This positive anomaly is conspicuously connected to the positive anomaly associated with two masses of the Lone Mountain pluton, designated ES-12.

Comment: The pluton is in the Walker Lane Fault Zone and is approximately $20 \mathrm{~km}$ southeast of the Nevada seismic zone. 


\section{ES-12. LONE MOUNTAIN}

General location: Lone Mountain and north part of the General Thomas Hills.

Coordinates: lat $38^{\circ} 01^{\prime}$ N., long $117^{\circ} 26^{\prime} \mathrm{W}$.

Land classification: Public domain, with some patented mining claims.

Area: $67 \mathrm{~km}^{2}$ (cumulative).

Accessibility: $11 \mathrm{~km}$ south of U.S. Highway 6 and 95.

Remoteness: $20 \mathrm{~km}$ west of Tonopah (in Nye County, population 1,716).

Geologic setting: The pluton is composed mainly of Cretaceous quartz monzonite, with some diorite, and intrudes the following: Precambrian Wyman Formation, composed of siltstone and limestone, and the Reed Dolomite; Precambrian and Cambrian Campito Formation, composed of siltstone and quartzite; and the Cambrian Poleta Formation, which includes carbonates, siltstone, and quartzite; and the Cambrian Harkless Formation, composed of siltstone. Thin diabase dikes intrude the pluton and sedimentary rocks.

Several age determinations have been obtained from the intrusive rocks and are as follows: Siberman, Bonham, Garside, and 0sborne (1975) report two K-Ar ages, 69.2 \pm 1.4 m.y. on biotite from the granitic body and $71 \pm 1.4 \mathrm{~m} . \mathrm{y}$. on muscovite from a pegmatite mass within the granitic body; Albers and Stewart (1972) report three K-Ar ages, $367 \pm 18$ m.y. on hornblende from a dike cutting the pluton and $67.2 \pm$ and $19.5 \pm$ m.y. respectively, from biotite obtained from different localities of the pluton, and finally, Edwards and McLauglin (1972) report a 63.7-m.y. age on biotite from the pluton.

The structure consists of thrust faults displacing the Precambrian and Paleozoic rocks. The major structures of the area include the Walker Lane Fault Zone and the Warm Springs lineament (fig. 8) located in Big Smoky Valley, $2 \mathrm{~km}$ north-northwest of the pluton. Fault scarps in the alluvium north and northwest of the pluton are probably related to the Warm Springs lineament.

Hydrologic setting: The pluton is in the Clayton Valley ground-water system and the Big Smoky Valley drainage basin. The nearest significant discharge is $21 \mathrm{~km}$ south, where the water is used industrially.

Aeromagnetic expression: A regional northwest-trending high-amplitude positive anomaly is clearly associated with the large main mass and smaller southeastern mass of the pluton. An isolated low-amplitude positive anomaly is associated with the northern mass of plutonic rocks. The anomaly data suggest that the main mass and southeastern mass of the Lone Mountain pluton are connected in the subsurface with the Weepah pluton, designated ES-11. The northern mass apparently occurs as an isolated exposure.

Comment: The pluton is in the WaTker Lane Fault Zone and is approximately $16 \mathrm{~km}$ southeast of the Nevada seismic zone, an active seismic area.

Selected reference: Albers and Stewart, 1972; Edwards and McLauglin, 1972; Siberman, Bonham, Garside, and Osborne, 1975. 


\section{ES-13. MILLER MOUNTAIN}

General location: Southeastern flank of Miller Mountain.

Coordinates: 1at $38^{\circ} 01^{\prime} \mathrm{N}$., long $118^{\circ} 09^{\prime} \mathrm{W}$.

Land classification: Public domain.

Area: $1 \mathrm{~km}^{2}$.

Accessibility: $2 \mathrm{~km}$ north of U.S. Highway 6 and approximately $11 \mathrm{~km}$ east of State Highway 10

(not shown on fig. 8).

Remoteness: $11 \mathrm{~km}$ east of Basalt, and $21 \mathrm{~km}$ west of Coaldale (population 35).

Geologic setting: The pluton is quartz monzonite and intrudes the Precambrian and Cambrian

Campito Formation and is overlain unconformably by Tertiary welded ash-

flow tuffs. Other rock units include the Cambrian Poleta Formation and

Cambrian marble and siliceous hornfels.

The structure consists of northeast-trending high-angle normal faults.

Hydrologic setting: The pluton is in the Columbus Salt Marsh ground-water system and closed drainage basin. The nearest discharge is $11 \mathrm{~km}$ east and the water is unused,

Aeromagnetic expression: A low-amplitude positive anomaly, at the northern margin of a crescentshaped negative anomaly, is associated with the small exposure.

Mining activity: A diatomite mining operation is located $2 \mathrm{~km}$ south of intrusive.

Comment: The intrusive body is located $20 \mathrm{~km}$ north of the Death Valley-Furnace Creek Fault Zone and is within the Nevada seismic zone. 
ES-14. CANDELARIA HILLS

General location: Southeastern flank of the Candelaria Hills:

Coordinates: Two outcrops located at 1 at $38^{\circ} 08^{\prime} \mathrm{N}$, , long $117^{\circ} 58^{\prime} \mathrm{W}$; 1at $38^{\circ} 09^{\prime}$ N., $10 \mathrm{ng} 117^{\circ} 57^{\prime} \mathrm{W}$. Land classification: Public domain.

Area: $1 \mathrm{~km}^{2}$ (cumulative).

Accessibility: One outcrop is approximately $5 \mathrm{~km}$ southwest of U.S. Highway 95 ; the other is intersected by U.S. Highway 95.

Remoteness: $65 \mathrm{~km}$ west of Tonopah (Nye County, population 1,716) and $15 \mathrm{~km}$ northwest of Coaldale (population 35).

Geologic setting: The granitic intrusive is quartz monzonite that intrudes the Ordovician Palmetto Formation, composed of shale, chert, limestone, and quartzite.

The predominant structure includes northeast- and northwest-trending highangle normal faults and minor thrust faults. The intrusive body is located within the Walker Lane Fault Zone and is $35 \mathrm{~km}$ northeast of the northern end of the Death Valley-Furnace Creek Fault Zone.

Hydrologic setting: The pluton is in the Columbus Salt Marsh ground-water system and closed drainage basin. The nearest discharge is $1 \mathrm{~km}$ south and the water is unused.

Aeromagnetic expression: The two small exposures occur on the northern and southwestern flanks of the northwest-trending nose of a regional high-amplitude positive anomaly caused in part by an unknown buried source and in part by andesitic tuffs and flows and associated extrusive rocks.

Comments: The intrusive body is located within the Walker Lane Fault Zone, is approximately $35 \mathrm{~km}$ northeast of the Death Valley-Furnace Creek Fault Zone, and is within the Nevada seismic zone. 


\section{ES-15. MONTE CRISTO}

General location: Northeastern Monte Cristo Range,

Coordinates: lat $38^{\circ} 09^{\prime} \mathrm{N}$., long $117^{\circ} 39^{\prime} \mathrm{W}$.

Land classification: Public domain.

Area: Less than $1 \mathrm{~km}^{2}$.

Accessibility: $9 \mathrm{~km}$ northwest of U.S. Highway 6 and 95 .

Remoteness: $41 \mathrm{~km}$ northwest of Tonopah (Nye County, population 1,716) and $22 \mathrm{~km}$ northeast of Coaldale (population 35).

Geologic setting: The intrusive body is quartz monzonite and intrudes the Ordovician

Palmetto Formation, composed of shale, chert, limestone, and quartzite.

The intrusive body is located within the Walker Lane Fault Zone.

Hydrologic setting: The pluton is in the Clayton Valley ground-water system and Big Smoky

Valley drainage basin. The nearest discharge is $10 \mathrm{~km}$ southeast where the water is unused.

Aeromagnetic expression: The exposure occurs at the western flank of a local high-amplitude positive anomaly that is associated largely with andesitic extrusive rocks.

Comment: The pluton is located in the Walker Lane Fault Zone and is at the edge of the Nevada seismic zone. 
ES-16. SOUTHERN ROYSTON HILLS

General location: Southern Royston Hills.

Coordinates: lat $38^{\circ} 15^{\prime} \mathrm{N}$., long $117^{\circ} 31^{\prime} \mathrm{W}$.

Land classification: Public domain.

Area: $2 \mathrm{~km}^{2}$ (cumulative).

Accessibility: $12 \mathrm{~km}$ north of U.S. Highway 6 and 95.

Remoteness: $33 \mathrm{~km}$ northwest of Tonopah,

Geologic setting: The intrusive consists of quartz monzonite and intrudes the Middle Triassic(?)

Excelsior Formation, composed of greenstone, breccia, and tuffaceous

sandstone, and is overlain unconformably by ash-flow tuffs of Tertiary

age. The Excelsior Formation, Tertiary volcanic rocks, and pluton have

all been displaced by high-angle normal faults. The pluton occurs with-

in the Walker Lane Fault Zone.

Hydrologic setting: The pluton is in the Clayton Valley ground-water system and the Big Smoky Valley drainage basin. The nearest discharge is $12 \mathrm{~km}$ southeast, where the water is unused.

Aeromagnetic expression: The small exposures occur at the eastern gentle gradient of a regional high-amplitude positive anomaly associated with a composite of extrusive rocks.

Comment: The pluton is located within the Walker Lane Fault Zone and is very near the edge of the Nevada seismic zone. 


\section{MINERAL COUNTY}

\section{GEOLOGY}

Mineral County (fig. 9) is located along the western margin of the Basin and Range province. Topographically, most of the ranges in the county do not display the north- to northeast-trend characteristic of areas to the east. This discordance can be attributed to influences such as the northwest-trending Sierra Nevada batholith immediately to the west and structural features associated with the Walker Lane Fault Zone.

The Walker Lane, trending northwestward through the county, is a zone of deformation that includes extensive right-lateral strike-slip faults and low-angle normal faults. Deformation associated with the zone probably commenced in Early Jurassic time and has continued through the Cenozoic. Furthermore, a zone of high seismic activity, commonly referred to as the Nevada seismic zone, extends northward through the county. Some of the recent earthquakes associated with this zone include the Cedar Mountains earthquake of 1932 and the Excelsior Mountains earthquake of 1934.

Most of the ranges and hills within the county contain exposures of granitic rock. The granitic masses range in size from dikes and small stocks to batholiths, such as the Wassuk Range; they consist mainly of quartz monzonite but range in composition from diorite to granite. The close similarity of textural and compositional characteristics of these granitic masses with those in the Sierra Nevadas suggest a satellitic association with the composite Sierra Nevada batholith.

Most of the granitic bodies intrude sedimentary and volcanic assemblages of Mesozoic age. Many of the intrusions appear to have been along zones of weakness associated with folding, thrusting, and lateral faulting during Mesozoic time.

The overabundance of small isolated intrusive outcrops throughout the area makes a compilation on an individual basis impractical. Therefore, exposures have been grouped into distinct geographic segments, predominantly mountain ranges and hills (fig. 9).

\section{HYDROLOGY}

The Walker River, with Walker Lake basin at its terminus, drains most of western Mineral County. The area along the California State line between Alkali and Queen Valleys drains primarily into Mono, Adobe, and Benton Valleys in California. Drainage of the eastern third of Mineral County is principally into Gabbs and Soda Spring Valleys and into local depressions, such as Teels Marsh and Garfield Flat.

Most of the runoff entering the Walker River originates in the Sierra Nevada in California. The major sources of runoff and recharge within the county are the Wassuk Range and the Excelsior Mountains. Minor sources of moisture for recharge include Cedar and Pilot Mountains and the Gabbs Valley Range.

Mason Valley and Walker Lake ground-water systems underlie most of the western half of the county. Gabbs Valley ground-water system, thought to be hydrologically closed, underlies the northeastern part of Mineral County and vicinity. The Rhodes Salt Marsh ground-water system, terminating in Rhodes Salt Marsh, receives subsurface flow from much of the central 


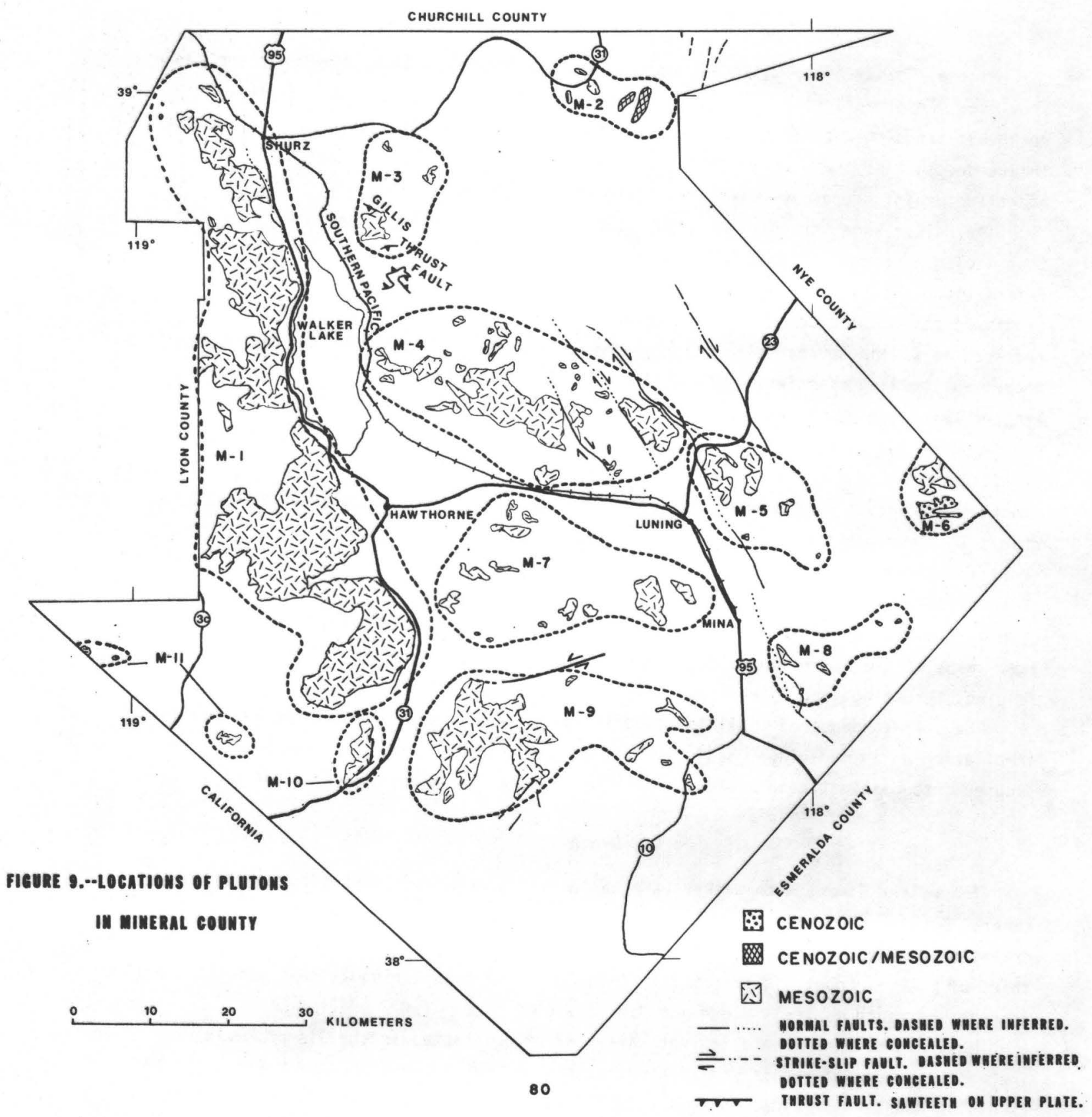


eastern part of the county, including the north-south reach of Soda Spring Valley. East and southeast Mineral County are in the peripheral western part of the Clayton Valley ground-water system. The Columbus Salt Marsh ground-water system receives flow from part of southern Mineral County. In areas along much of the California State line, ground water moves southwestward similar to the surface-water drainage.

The hydrology of Mineral County was taken Targely from the following references: Eakin, 1962a; Everett and Rush, 1967; and Van Denburgh and G1ancy, 1970. 


\section{M-1. WASSUK RANGE}

General location: North-northwest-trending range along the western border of Mineral County. Coordinates: lat $38^{\circ} 35^{\prime}$ N., long $118^{\circ} 48^{\prime}$ W. (Mount Grant).

Land classification: Northern exposures--Walker River Indian Reservation.

Central exposures--Hawthorne Naval Ammunition Depot.

Southern exposures--Private lands and Toiyabe National Forest.

Area: $570 \mathrm{~km}^{2}$ (cumulative).

Accessibility: U.S. Highway 95 passes along the northern end of the eastern flank of the range and a few unimproved roads penetrate the range and intersect State Highway 31 , which continues southward along the eastern flank. Light-duty al1-weather State Highway $3 C$ passes along the western flank in Lyon County.

Remoteness: The two populated areas include the towns of Hawthorne and Yerington. Hawthorne (population 3,539) lies approximately $5 \mathrm{~km}$ east of the eastern flank, and Yerington (population 2,010) lies about $20 \mathrm{~km}$ west of the northwestern flank in Lyon County.

Geologic setting: The Wassuk Range extends in a northwest direction for more than $80 \mathrm{~km}$ and is marked by a prominent steep eastern slope and a much gentler western slope.

More than 50 percent of the range consists of exposures of granitic rock and the remainder is made up of large, irregular-shaped roof pendants that may reach a maximum thickness of hundreds of meters. These pendants are composed of metavolcanic rocks of the Middle Triassic(?) Excelsior Formation. Tertiary volcanic rocks discontinuously overlie the granite mass along the western margin, and parts of the northern and southern boundaries contain Quaternary volcanic flows.

The granitic outcrops are predominantly composed of quartz monzonite, granodiorite, and granite of Cretaceous(?) age. Subordinate exposures of diorite and related rocks crop out within the complex and are probably Cretaceous or Jurassic in age.

The most prominent structural feature consists of a discontinuous set of northwest-trending normal faults that delineate the eastern base of the range. Scarps mapped in alluvial fans indicate relatively recent movement.

Hydrologic setting: The range is in the Walker Lake ground-water system. Runoff drains to Walker Lake to the east and to the East Walker River and Mason Valley on the west. The discharge points nearest the center of the range are $7 \mathrm{~km}$ east and $11 \mathrm{~km}$ west of the center, where water is used for irrigation, domestic, recreation, and livestock purposes.

Aeromagnetic expression: A regional northwest-trending high-amplitude negative anomaly, developed over the northern exposures of granitic rocks, appears to be associated in part with extensive outcrops of basalt. The 
central exposures have a highly complex magnetic signature, with short-wavelength dipole anomalies appearing over the northern and southern parts of this mass. The southern exposures are also magnetically complex inasmuch as three distinct positive anomalies and one negative anomaly are developed over the exposure. It is inferred that large magnetization variations occur within the intrusive rocks or that much of the granitic rock terrane is relatively thin; the unknown underlying rocks accounting for many of the diverse anomalies.

Mining activity: Along the western slope, three gold and silver mines are currently

(1976) in operation southwest of Mount Grant and west of Bald Mountain. One silica mine exists near the southern margin of the range, about $12 \mathrm{~km}$ south of Mount Grant.

Comment: The eastern part of the range lies within the Walker Lane and Nevada seismic zone. 


\section{M-2. RAWHIDE-EAGLEVILLE DISTRICT}

General location: Northeastern part of county.

Coordinates: lat $39^{\circ} 00^{\prime} \mathrm{N}$., long $118^{\circ} 18^{\prime}$ W. (central location).

Land classification: Public domain.

Area: $13 \mathrm{~km}^{2}$ (cumulative).

Accessibility: State Highway 31 crosses over one of the outcrops and terminates. A light-

duty road extends westward and intersects U.S. Highway 95 .

Remoteness: The town of Schurz (population 300) lies $40 \mathrm{~km}$ west of the exposures, and Gabbs

(Nye County, population 874) lies $30 \mathrm{~km}$ to the southeast.

Geologic setting: The Cenozoic and (or) Mesazoic granitic masses in the area intrude intermediate and felsic volcanic rocks of the Middle Triassic(?) Excelsior Formation. Tertiary intermediate and felsic volcanic rocks overlie the Excelsior along the western and eastern margins. Several fault scarps in the volcanic rocks east of intrusives were developed during the Fairview Peak-Dixie Valley earthquake of December 16, 1954.

Hydrologic setting: The area is in the Gabbs Valley ground-water system and drainage basin, both hydrologically closed. The nearest discharge is $8 \mathrm{~km}$ south where water is used for livestock and domestic purposes.

Aeromagnetic expression: A broad magnetic plateau is developed over the exposed granitic rocks. The maximum areal extent of the buried source is estimated to be $25 \mathrm{~km}^{2}$.

Mining activity: Tungsten is currently (1976) being mined within the area.

Comment: The area lies within the Nevada seismic zone and Walker Lane Fault Zone. Selected reference: Ross, 1961. 


\section{M-3. NORTHERN GILLIS RANGE}

General location: Northeast of Walker Lake.

Coordinates: 1at $38^{\circ} 53^{\prime} \mathrm{N}$., long 118 $36^{\prime} \mathrm{W}$. (central location).

Land classification: Walker River Indian Reservation.

Area: $12 \mathrm{~km}^{2}$ (cumulative).

Accessibility: U.S. Highway 95 and the Southern Pacific Railroad parallel the western flank of the Gillis Range and are, respectively, $10 \mathrm{~km}$ and $5 \mathrm{~km}$ from the nearest exposure at Gillis Canyon. A light-duty all-weather road flanks the northern part of the area $2 \mathrm{~km}$ north of the northern exposures.

Remoteness: The town of Schurz (population 300) is approximately $16 \mathrm{~km}$ northwest, and

Hawthorne (population 3,539) is within $39 \mathrm{~km}$ of the southern outcrop.

Geologic setting: The northern Gillis Range is the northern extremity of an arcuate S-shaped mountain block that also includes the Gabbs Valley Range and the Pilot Mountains.

The region is predominantly overlain by Tertiary felsic volcanic rocks, except for a few scattered Cretaceous(?) exposures of granitic rock that cut exposed metasediments and sedimentary sequences of the Triassic Luning and Middle Triássic(?) Excelsior Formations.

The Gillis thrust is exposed at several places within the range. The thrust has brought the Excelsior over the younger Luning Formation in an area along the northern margin of the intrusive.

Hydrologic setting: The area is in the Walker Lake ground-water system and drainage basin.

The nearest significant discharge is into Walker Lake, $14 \mathrm{~km}$ southwest, where water is used principally for recreation.

Aeromagnetic expression: The main mass occurs on the northern flank of a west-trending positive anomaly; the northern mass is located beneath the western flank of a broad positive anomaly. The principal sources of both anomalies are inferred to be extrusive rocks.

Selected reference: Ross, 1961. 


\section{M-4. SOUTHERN GILLIS RANGE}

General location: Northeast of Hawthorne and east of Walker Lake.

Coordinates: lat $38^{\circ} 39^{\prime} \mathrm{N}$. , long $118^{\circ} 25^{\prime}$ W. (central location).

Land classification: Public domain, except for a few local patented mining claims.

Area: $135 \mathrm{~km}^{2}$ (cumulative).

Accessibility: U.S. Highway 95 and the Southern Pacific Railroad pass along the western

flank of the range and State Highway 23 extends along the southern margin,

intersecting U.S. Highway 95 at Luning.

Remoteness: The town of Hawthorne (population 3,539) is located about $16 \mathrm{~km}$ southeast of the outcrops, and Luning (population 60) lies $9 \mathrm{~km}$ south of the southern exposures.

Geologic setting: The southern part of the Gillis Range predominantly consists of Cretaceous(?)

exposures of granitic rock that cut limestones, dolomites, and shales of the Luning Formation and intermediate to felsic volcanic rocks of the Middle Triassic(?) Excelsior Formation. In the southern part, where the Gillis Range joins the Gabbs Valley Range, several northwest-trending rightlateral strike-slip faults, associated with the Walker Lane Fault Zone, offset intrusives and sedimentary and volcanic assemblages.

Most of the intrusives are composed of quartz monzonite and subordinate granodiorite. Several exposures have been mapped as diorite and related rocks and appear to be intruded by the more silicic varieties.

Hydrologic setting: The range is in the Walker Lake and Gabbs Valley ground-water systems, and runoff drains to Walker Lake, Gabbs Valley, and western Soda Spring Valley. The nearest and most significant discharge point is $21 \mathrm{~km}$ west of the center of the area into Walker Lake, although the southern outcrops are close to pumped wells in Soda Spring Valley, and some flow goes north to Gabbs Valley. Water in Walker Lake is used primarily for recreation.

Aeromagnetic expression: Most of the granitic rock mass has no strong magnetic expression.

A complex of positive anomalies, developed near the southeastern extremity of the main mass, appears to reflect a composite of intrusive and extrusive rocks.

Mining activity: Silver is being mined (1976) along the eastern flank of the range near Ryan Canyon, and a gold and silver mine is active along the southwestern flank, midway between Hawthorne and Luning.

Selected reference: Ferguson and Muller, 1949. 


\section{M-5. SOUTHERN GABBS VALLEY RANGE}

General location: Northeast of Luning in eastern part of county.

Coordinates: lat $38^{\circ} 32^{\prime}$ N., long $118^{\circ} 06^{\prime}$ W. (central location).

Land classification: Public domain and several patented mining claims.

Area: $30 \mathrm{~km}^{2}$ (cumulative).

Accessibility: U.S. Highway 95 and Southern Pacific Railroad parallel the range on the west side of Soda Spring Valley, and State Highway 23 provides easy access to the northern exposures.

Remoteness: The towns of Luning (population 60) and Hawthorne (population 3,539) are

situated $5 \mathrm{~km}$ to the southwest and $41 \mathrm{~km}$ to the west, respectively.

Geologic setting: The southern part of the range is underlain by limestone, dolomite, and shale of the Triassic Luning Formation. Intercalated shale and limestone of the Gabbs and Sunrise Formations, in addition to sandstone and volcanic rocks of the Jurassic Dunlap Formation, also crop out in the area. All the formations have been intruded by quartz monzonite, granodiorite, and diorite of Cretaceous(?) age.

The major Mesozoic structures found in the area are Late Jurassic thrusts that placed strata of the Luning Formation over the Dunlap. Cenozoic faults are the prominent structures associated with the plutons. Most of the granitic bodies are flanked by northwest-trending right-lateral strike-slip faults associated with the Walker Lane Fault Zone. At some places, granite found along these faults exhibits crushed, pulverized, and argillized zones.

Hydrologic setting: The area is in the Rhodes Salt Marsh ground-water system and runoff drains to eastern Soda Spring Valley. The nearest discharge is $9 \mathrm{~km}$ west, near Luning, and water in the area is used mainly for livestock, domestic, and some industrial (mining) purposes.

Aeromagnetic expression: High-amplitude positive anomalies are clearly associated with the granitic rocks. The granitic rock terrane appears to extend continuously beneath alluvium from the northwestern exposure to the southeastern one. The maximum areal extent of the subsurface source is estimated to be $15 \mathrm{~km}^{2}$.

Selected reference: Ross, 1961. 


\section{M-6. CEDAR MOUNTAIN}

General location: Near the eastern corner of county.

Coordinates: lat $38^{\circ} 32^{\prime} \mathrm{N}$, long $117^{\circ} 49^{\prime} \mathrm{W}$.

Land classification: Public domain.

Area: $21 \mathrm{~km}^{2}$ (cumulative).

Accessibility: U.S. Highway 95 is $28 \mathrm{~km}$ southwest of the outcrops. Unimproved mining roads intersect Highway 95 at Mina and lead into the area. State Highway 89 (Nye County) passes $6 \mathrm{~km}$ northeast of outcrop along the eastern flank of the range.

Remoteness: Mina (population 425) is located $28 \mathrm{~km}$ tc the southwest, and Gabbs (Nye County, population 874 ) is $35 \mathrm{~km}$ to the north.

Geologic setting: The flanks of Cedar Mountain are generally overlain by Tertiary volcanic rocks that include the pre-Esmeralda, Esmeralda, and felsic volcanic rocks. Granodiorite and quartz monzonite of Tertiary age, forming the central core of the range, intrude limestone of the Triassic Luning Formation. An age of $40 \pm 10 \mathrm{~m} . \mathrm{y}$. was determined by the lead-alpha method on zircon from the southern granitic mass (Schilling, 1965). This suggests that some of the granitic rocks in Mineral County may be younger than the Sierra Nevada intrusives. Numerous felsic and mafic dikes occur in and around the margins of the granodiorite.

Cenozoic faults have been mapped along the western flank and central part of the mountain range, but most of the structure is obscured by the easily eroded volcanic rocks. This area is still tectonically active, as indicated by the development of several small faults in the valley between Cedar Mountain and the Pilot Mountains during the earthquake of December 20, 1932.

Hydrologic setting: The mountains are in the Clayton Valley ground-water system and the Ione Valley drainage basin. The nearest discharge point is $12 \mathrm{~km}$ east at a spring in southern Ione Valley. The water is used by livestock.

Aeromagnetic expression: High-amplitude positive anomalies are clearly associated with the granitic rocks. The anomalous field and inferred distribution of rocks make a $45^{\circ}$ bend from west to northwest in the outcrop area. The high degree of isolation of the anomalous field reflects the nonmagnetic character of the intruded terrane of sedimentary rocks.

Selected references: Ferguson and Muller, 1949; Gianella and Callaghan, 1934; Knopf, 1921; and Schilling, 1965. 


\section{M-7. GARFIELD HILLS}

General location: Southeast of Hawthorne and north of the Excelsior Mountains.

Coordinates: lat $38^{\circ} 28^{\prime} \mathrm{N}$., long $118^{\circ} 21^{\prime}$ W. (central location).

Land classification: Predominantly public domain. Two of the western exposures are on the Hawthorne Naval Ammunition Depot. Numerous patented mining claims are scattered throughout the hills.

Area: $44 \mathrm{~km}^{2}$ (cumulative).

Accessibility: U.S. Highway 95 and the Southern Pacific Railroad pass along the eastern and northernflanks, and State Highway 31 is located near the western boundary of the hills.

Remoteness: The area is $14 \mathrm{~km}$ southeast of Hawthorne (population 3,539).

Geologic setting: The intrusives of Cretaceous(?) age include quartz monzonite, granodiorite, granite, and diorite. It has been suggested that the localization of some stocks may have been determined by preexisting zones of weakness associated with earlier thrusting episodes (Ferguson and Muller, 1949). Much of the western, southwestern, and northern parts of the hills are covered by Tertiary and Quaternary volcanic rocks.

The exposed rocks found in the Garfield Hills include cherty tuff, tuffaceous sandstone, and greenstone of the Middle Triassic(?) Excelsior Formation; slate, conglomerate, and limestone of the Triassic Luning Formation; slaty 1 imestone of the Triassic Gabbs and Jurassic Sunrise Formations; and sandstone, conglomerate, limestone, and greenstone of the Jurassic Dunlap Formation. The Triassic sequences have been intensely folded and intricately thrust faulted during Jurassic time.

Tertiary and Quaternary faults are subordinately present but tend not to complicate the Mesozoic structural features.

Hydrologic setting: The hills are in the Rhodes Salt Marsh and Walker Lake ground-water systems. Runoff drains to Walker Lake, Soda Spring Valley, and Garfield Flat. The nearest, most significant discharge point is $22 \mathrm{~km}$ southeast near Mina, where the water is used for livestock, domestic, and mining purposes.

Aeromagnetic expression: High-amplitude positive anomalies are associated with most of the exposed granitic rocks. The two easternmost bodies clearly serve as anomaly sources; those farther west are associated with basalt. A conspicuously crescent-shaped anomaly, possibly reflecting subsurface geologic structure, overlies the northwesternmost exposure.

Comment: Outcrops are within the Walker Lane Fault Zone and the Nevada seismic zone. Selected references: Ferguscn and Muller, 1949; and Ferguson, Muller, and Cathcart, 1954. 


\section{M-8. PILOT MOUNTAINS}

General location: Southeast of Mina.

Coordinates: lat $38^{\circ} 20^{\prime}$ N., long $118^{\circ} 00^{\prime}$ W. (central location).

Land classification: Public domain.

Area: $8 \mathrm{~km}^{2}$ (cumulative).

Accessibility: U.S. Highway 95 passes $6 \mathrm{~km}$ west of the outcrops.

Remoteness: The outcrops are situated $6 \mathrm{~km}$ southeast of Mina (population 425), and $54 \mathrm{~km}$ southeast of Hawthorne (population 3,539).

Geologic setting: Several Cretaceous outcrops of granitic rocks, predominantly granodiorite, intrude the Middle Triassic(?) Excelsior Formation along the western flank and the Triassic Luning Formation along the eastern flank of the mountains.

An age of $68.7 \pm 1.8$ m.y. was determined by potassium-argon methods on a sample of quartz monzonite from the westernmost exposure (Schilling, $1965)$.

Although the Pilot Mountains are dominantly made up of Excelsior, Luning, and Dunlap Formations, these assemblages are overlapped by Tertiary intermediate volcanic rocks along the northern margins and by Tertiary sedimentary and volcanic sequences of the Tertiary Esmeralda Formation along the southern border.

The structure of the area is somewhat complex owing to several episodes of intense folding, overturning, and thrusting of the Mesozoic strata. Both the eastern and western margins of the mountains are bounded by northwest-striking Tertiary and Quaternary fault scarps, of which the western scarp is the most conspicuous.

Hydrologic setting: The area is mainly in the Rhodes Salt Marsh ground-water system.

Principal surface-water drainage is to Soda Spring Valley. The nearest discharge is $10 \mathrm{~km}$ southwest into the marsh. Water is used in the vicinity of the marsh for livestock.

Aeromagnetic expression: The exposures of granitic rocks occur mainly beneath the flanks of high-amplitude positive anomalies. The subsurface anomaly source is inferred to be granitic rocks inasmuch as no other candidate magnetic rocks are exposed in the area. The maximum areal extents of the inferred sources of the two principal anomalies are $15 \mathrm{~km}^{2}$ and $10 \mathrm{~km}^{2}$, that is, a cumulative areal extent of $25 \mathrm{~km}^{2}$.

Comment: The area is located within the Walker Lane Fault Zone and Nevada seismic zone. Selected references: Ferguson and Muller, 1949; Phoenix and Cathcart, 1952; and Schilling, 1965. 
General location: Southeast of Hawthorne and west of the Pilot Mountains.

Coordinates: lat $38^{\circ} 16^{\prime}$ N., long $118^{\circ} 29^{\prime} \mathrm{W}$.

Land classification: The western half of the main granitic mass is located within Toiyabe

National Forest. The eastern outcrops are within public domain.

Area: $123 \mathrm{~km}^{2}$ (cumulative).

Accessibility: State Highway 31 borders the northwestern edge of the mountains, and U.S.

Highway 95 passes along the eastern border. Also, State Highway 10 passes near the southeastern border.

Remoteness: Hawthorne (population 3,539) is $27 \mathrm{~km}$ to the northwest, and Mina (population

425) is $14 \mathrm{~km}$ to the northeast.

Geologic setting: The nearly east-trending range is not well delineated along its western and northern boundaries where it merges with the Anchorite Hills and Garfield Hills, respectively. The western part of the Excelsior Mountains consists of a large Cretaceous(?) granite mass of very coarse quartz monzonite and granodiorite, similar in appearance to that of the Wassuk Range. This mass intrudes rocks of the Middle Triassic(?) Excelsior and Jurassic Dunlap Formations. Tertiary volcanic rocks overlap most of the southern part of the intrusive. The smaller bodies to the east include diorite, quartz monzonite, granite, and granite porphyry that intrude the Excelsior Formation.

Some of the normal faults that parallel the southern range front cut rocks as young as Pleistocene. In this area, the earthquake of January 30, 1934, produced a scarp $760 \mathrm{~m}$ long and $12.5 \mathrm{~cm}$ high, cutting the Excelsior (Callaghan and Gianella, 1935).

Hydrologic setting: The area is in Teels Marsh, Walker Lake, and Rhodes Salt Marsh groundwater systems, ranked in order of importance. Runoff drains mainly to Teels Marsh, hiuntoon Valley, and Whisky Flat. The nearest discharge to the geographic center of the area is $5 \mathrm{~km}$ southeastward in Teels Marsh, where water is used primarily for livestock.

Aeromagnetic expression: The main mass of granitic rocks has a highly complex magnetic signature, in that positive and negative anomalies are prominently developed. Short-wavelength, high-amplitude anomalies over sedimentary rock terrane of the mountains are presumably caused by buried plutons having typical areal extents of about $5 \mathrm{~km}^{2}$.

Mining activity: A tungsten mine is (1976) in operation along the northwestern flank of the range.

Comment: The area is situated within the Walker Lane Fault Zone and Nevada seismic zone. Selected references: Callaghan and Gianel1a, 1935; and Ferguson, Muller, and Cathcart, 1954. 
General location: South of the Wassuk Range.

Coordinates: lat $38^{\circ} 15^{\prime}$ N., long 118 $40^{\prime} \mathrm{W}$.

Land classification: Toiyabe National Forest.

Area: $13 \mathrm{~km}^{2}$.

Accessibility: State Highway 31 passes along the eastern edge of the outcrop.

Remoteness: Hawthorne (population 3,539) lies $38 \mathrm{~km}$ to the north.

Geologic setting: Many of the exposures of granitic rock underlying part of the hills are covered by Tertiary and Quaternary volcanic rocks, except along the eastern flank where the frontal scarp of the Wassuk Range extends southward and brings alluvial fill in contact with the body. The intrusive is chiefly composed of quartz monzonite and granodiorite of Cretaceous(?) age and is probably continuous with outcrops in the Wassuk Range. Numerous step faults offset Quaternary volcanic rocks north of the outcrop.

Hydrologic setting: The hills are primarily in the Mono Lake ground-water system, mostly in California. Runoff drains to Whisky Flat and Alkali Valley. The nearest significant discharge is $31 \mathrm{~km}$ southwest near Mono Lake, where water is used for livestock, irrigation, domestic, and recreation purposes.

Aeromagnetic expression: No single, well-defined anomaly is associated with the granitic rocks.

Selected reference: Ross, 1961. 


\section{M-11. AURORA MINING DISTRICT}

General location: Southwest of Wassuk Range, near the Nevada-California State line (includes two outcrops northwest of district).

Coordinates: lat $38^{\circ} 16^{\prime} \mathrm{N}$., long $118^{\circ} 52^{\prime} \mathrm{W}$.

Land classification: Public domain, private land, and Toiyabe National Forest.

Area: $6 \mathrm{~km}^{2}$ (cumulative).

Accessibility: State Highway 31 passes $11 \mathrm{~km}$ southeast of the outcrops. Light-duty Highway $3 \mathrm{C}$ is $9 \mathrm{~km}$ northwest of the southern exposures and $10 \mathrm{~km}$ southeast of the northern exposures.

Remoteness: Bridgeport, Calif. (population 500), is $31 \mathrm{~km}$ to the west, and Hawthorne (population 3,539) is $35 \mathrm{~km}$ to the northeast.

Geologic setting: A few isolated exposures of granitic rocks of Cretaceous(?) age intrude the Middle Triassic(?) Excelsior Formation. Tertiary pre-Esmeralda intermediate and felsic volcanic rocks and Quaternary mafic volcanic rocks cover most of the area.

Hydrologic setting: The district is in the Walker Lake ground-water system. Drainage goes mainly to the East Walker River. The nearest discharge occurs $15 \mathrm{~km}$ northwest in the East Walker River. Water is used in the area for irrigation, livestock, and domestic purposes.

Aeromagnetic expression: A distinct positive anomaly flexure is associated with the main mass of granitic rocks.

Selected reference: Ross, 1961. 


\section{LYON COUNTY}

GEOLOGY

Lyon County (fig. 10) is located in western Nevada and lies within the western Great Basin. The county lies on the eastern border of the Cretaceous Sierra Nevada batholith. The western part of the county is a gradational physiographic and structural break between the Sierra Nevada and the Basin and Range province.

The granitic bodies in the county are considered to be the eastern continuation of the Sierra Nevada batholith (Moore and Archbold, 1969), with pre-Cretaceous rocks present as roof pendants on the batholith. The pre-Cretaceous rocks consist of metamorphosed volcanic rocks and minor reworked volcanic rocks of Triassic and Jurassic age. The granitic bodies are overlain unconformably by Tertiary volcanic rocks and, to a lesser extent, by basalt flows of Tertiary-Quaternary age.

Deformation occurred in two general periods: one preceding and accompanying the emplacement of the Cretaceous granitic rocks, and another in late Tertiary and Quaternary time that caused normal faulting, warping, and tilting (Moore and Archbold, 1969). The major structure of the area is the Walker Lane Fault Zone located in the extreme north-northeast part of the county.

Lyon County is located west of the Nevada seismic zone (p1.5) and is seismically active. The geologic data were extracted and summarized from the following:

Moore and Archbold, 1969.

\section{HYDROLOGY}

The southern two-thirds of the county is drained by the East Walker River and Walker River which flows circuitously eastward to Walker Lake. The north-central part of the county is drained by the Carson River flowing northeastward into Carson Sink. The northern tip of the county drains into Bradys Hot Springs area, which is topographically closed.

Most of the runoff to Walker and Carson Rivers originates in the Sierra Nevada in California. The Pine Grove Hills, Sweetwater Mountains, and Lyon Peak, all in the southern part, are the chief sources of recharge and runoff within the county.

The Walker Lake ground-water system, featuring movement generally in the same direction as the Walker River, underlies all the southern two-thirds of the county. The Carson Sink ground-water system, having subsurface flow generally northeastward toward the sink, covers most of the northern part of the county. Bradys Hot Springs ground-water system is in the northernmost tip of Lyon County.

The hydrology of Lyon County was taken principally from the following references:

G1ancy, 1971; Glancy and Katzer, 1976; Huxe1, 1969. 


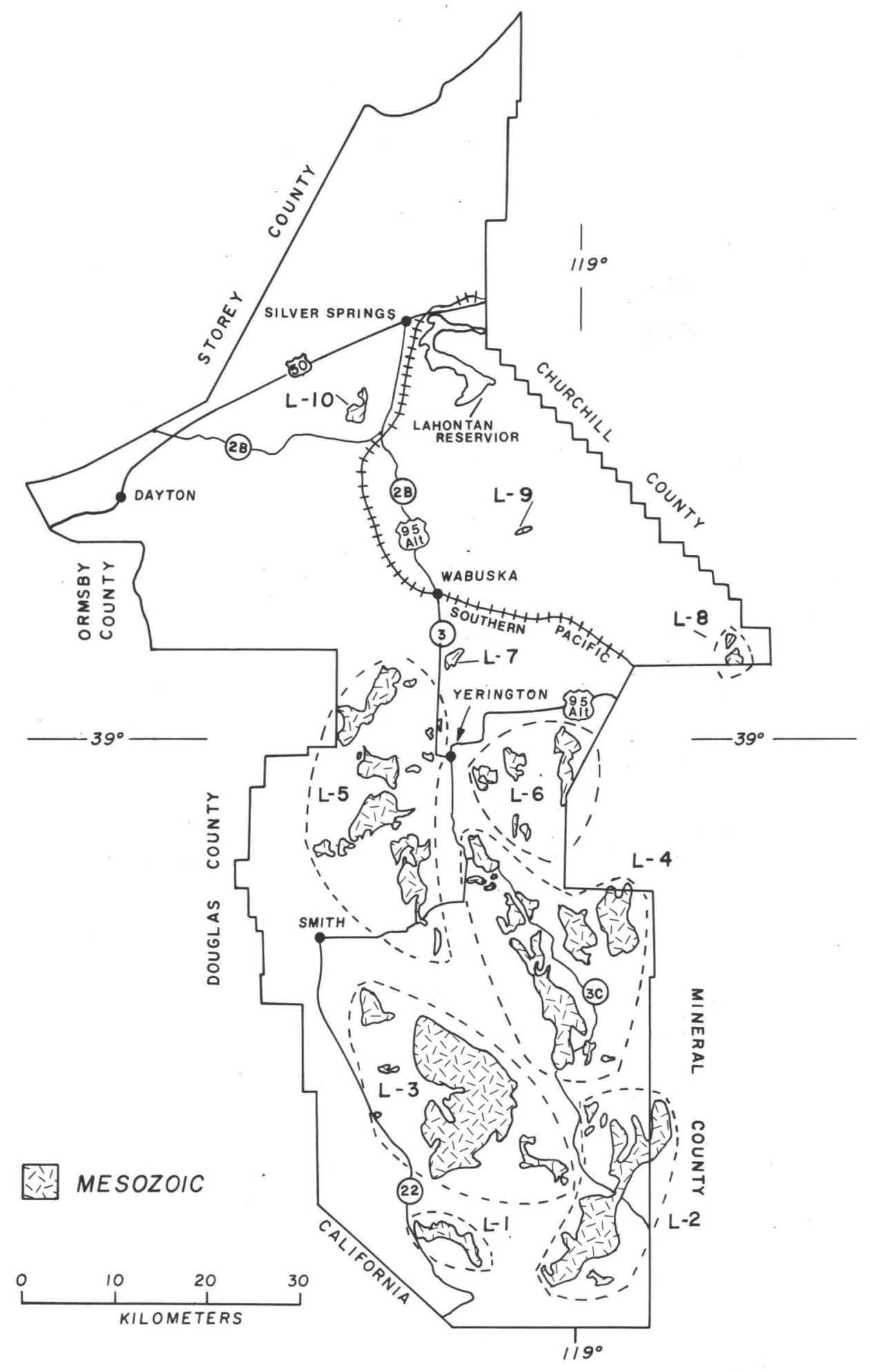

FIGURE 10.-- LOCATIONS OF PLUTONS IN LYON COUNTY 


\section{L-1. ROUND MOUNTAIN}

General location: Round Mountain, southwestern part of the Pine Grove Hills.

Coordinates: lat $38^{\circ} 30^{\prime} \mathrm{N}$, long $119^{\circ} 10^{\prime} \mathrm{W}$.

Land classification: Toiyabe National Forest.

Area: $12 \mathrm{~km}^{2}$.

Accessibility: State Highway 22 is just west of the western tip of the pluton. Remoteness: $33 \mathrm{~km}$ southeast of Smith, $51 \mathrm{~km}$ south of Yerington (population 2,010).

Geologic setting: The Round Mountain pluton is composed of Cretaceous quartz monzonite and granodiorite, and intrudes Triassic-Jurassic metavolcanic rocks. The metavolcanics consist of andesitic breccias, tuffs, and lava flows. The pluton is overlain in some areas unconformably by andesitic flow breccias, lava flows, agglomerates, and, locally, by basaltic and rhyolitic rocks of Tertiary age.

The Round Mountain area forms the southern part of the Pine Grove Hills, an uplifted fault block that consists of high-angle normal faults.

Hydrologic setting: The pluton is in the Walker Lake ground-water system. Runoff flows to East Walker River and to Sweetwater Flat. The nearest discharge is $7 \mathrm{~km}$ southeast in the East Walker River, and water is used for livestock, irrigation, and domestic purposes.

Aeromagnetic expression: No single, well-defined anomaly is associated with the pluton.

Comment: The pluton is located in a seismically active area east of the Nevada seismic zone, approxiamtely $45 \mathrm{~km}$ west of the Walker Lane Fault Zone, and $32 \mathrm{~km}$ north of the Bridgeport Reservoir. 
General location: Southernmost Pine Grove Hills, southeastern part of the county.

Coordinates: lat $38^{\circ} 33^{\prime} \mathrm{N}$., long $118^{\circ} 57^{\prime} \mathrm{W}$.

Land classification: Predominantly public domain, with some private lands and national forest. Area: $64 \mathrm{~km}^{2}$ (cumulative).

Accessibility: State Highway 3 C intersects pluton.

Remoteness: Main outcrop is $50 \mathrm{~km}$ southeast of Yerington (population 2,010) and northernmost outcrop is $40 \mathrm{~km}$ southeast of Yerington.

Geologic setting: The pluton is composed of Cretaceous porphyritic quartz monzonite and granodiorite. The granitic rocks intrude Triassic-Jurassic metavolcanic rocks. The pluton is overlain unconformably by andesitic and sedimentary rocks of Tertiary age and in some areas by basalt flows of TertiaryQuaternary age. The structure consists of high-angle normal faults that bound the pluton on the southwest margin of the granitic body.

Hydrologic setting: The pluton is in the Walker Lake ground-water system and the area is drained by the East Walker River. Discharge occurs in East Walker River, which flows through the west side of the pluton area. Water is used for livestock, irrigation, and domestic purposes.

Aeromagnetic expression: The masses of granitic rock occur in an area of low magnetic relief. No distinct anomalies are associated with the rocks.

Mining activity: Gold and silver mining.

Comments: The pluton occurs west of the Nevada seismic zone, in a seismically active area, and approximately $20 \mathrm{~km}$ southwest of the Walker Lane Fault Zone. The pluton is also near gold and silver mining in the area. Northeasternmost outcrop is $11 \mathrm{~km}$ southwest of Walker Lake. 


\section{L-3. PINE GROVE HILLS}

General location: Central and southern part of the Pine Grove Hills.

Coordinates: lat $38^{\circ} 39^{\prime}$ N., long $119^{\circ} 07^{\prime} \mathrm{W}$.

Land classification: Predominantly Toiyabe National Forest, with some patented mining claims

Area: $147 \mathrm{~km}^{2}$ (cumulative). and public domain.

Accessibility: Main outcrop is $2 \mathrm{~km}$ east of State Highway 22 and $5 \mathrm{~km}$ west of State Highway $3 \mathrm{C}$.

Remoteness: $12 \mathrm{~km}$ southeast of Smith and $28 \mathrm{~km}$ south of Yerington (population 2,010).

Geologic setting: The pluton is composed of scattered outcrops of Cretaceous porphyritic quartz monzonite, quartz monzonite, and granodiorite and intrudes metasedimentary rocks of Triassic-Jurassic age; it is overlain unconformably by sedimentary and rhyolitic volcanic rocks of Tertiary age. In some areas the pluton is overlain by basalt flows of Tertiary-Quaternary age. The porphyritic quartz monzonite has been dated as $87.0+2.7 \mathrm{~m} . y$. and 90.0 -2.7 m.y. (Krueger and Schilling, 1971). The Pine Grove Hills are an uplifted block tilted to the west and consist of high-angle normal faults that cut the pluton.

Hydrologic setting: The pluton is in Walker Lake ground-water system and drainage is to Mason and Smith Valleys. The nearest discharge is $20 \mathrm{~km}$ north in Mason Valley. Water is used in Mason and Smith Valleys for irrigation, livestock, and public-supply purposes.

Aeromagnetic expression: The pluton has a complex magnetic signature; half of the outcrop area is associated with negative anomalies and half with positive anomalies.

Comment: The pluton is located approximately $35 \mathrm{~km}$ west of the Walker Lane Fault Zone, and west of the Nevada seismic zone; occurs in a seismically active area.

Selected reference: Krueger and Schiliing, 1971. 
General 1ocation: Eastern part of the county near the East Walker River:

Coordinates: lat $38^{\circ} 46^{\prime}$ N., long 119 $03^{\prime}$ W.

Land classification: Private land and public domain.

Area: $90 \mathrm{~km}^{2}$ (cumulative).

Accessibility: State Highway 3 C intersects a part of the pluton.

Remoteness: Main outcrop is $21 \mathrm{~km}$ southeast of Yerington (population 2,010), the northernmost outcrop is $9 \mathrm{~km}$ southeast of Yerington.

Geologic setting: The pluton is composed of Cretaceous quartz monzonite and granodiorite, and intrudes metavolcanic rocks of Triassic-Jurassic age. Andesitic and rhyolitic rocks of Tertiary age overlie the pluton unconformably in some areas.

The Walker Lane Fault Zone, located $15 \mathrm{~km}$ east of the pluton, is the major structure of the area. The predominant structure in the vicinity of the pluton consists of high-angle normal faults of Tertiary age.

Hydrologic setting: The pluton is in the Walker Lake ground-water system. Runoff drains to the East Walker River. The Mason Valley discharge area includes the northwestern part of pluton exposures. Water is used in Mason Valley for irrigation, livestock, and public supply.

Aeromagnetic expression: The granitic rocks are somewhat obscurely associated with lowamplitude positive anomalies in a region of low magnetic relief. No inferences about anomaly sources can be made.

Comments: The pluton is located in an active seismic area, west of the Nevada seismic zone and $15 \mathrm{~km}$ west of the Walker Lane Fault Zone. The easternmost outcrop is $16 \mathrm{~km}$ west of Walker Lake. 


\section{L-5. SINGATSE RANGE}

General location: Outcrops occur all along the Singatse Range.

Coordinates: 1at $38^{\circ} 55^{\prime} \mathrm{N}$., long $119^{\circ} 15^{\prime} \mathrm{W}$.

Land classification: Predominantly public domain, with some patented mining claims, private

Area: $84 \mathrm{~km}^{2}$ (cumulative).

lands, and Bureau of Reclamation withdrawals.

Accessibility: The central part of the outcrop is $4 \mathrm{~km}$ west of State Highway 3 ; State Highway

3 intersects part of the pluton to the south. The northernmost outcrop is

$4 \mathrm{~km}$ west of State Highway 2B (U.S. Highway 95 Alt.).

Remoteness: Central part of the area is $8 \mathrm{~km}$ southwest of Yerington (population 2,010), with smaller outcrops occurring $2 \mathrm{~km}$ west of Yerington.

Geologic setting: The pluton is composed of scattered outcrops of Cretaceous granite porphyry, quartz monzonite, and granodiorite, and intrudes metavolcanic and metasedimentary rocks of Triassic-Jurassic age and is overlain by andesitic and rhyolitic volcanic rocks and sedimentary rocks of Tertiary age. In some areas the pluton is overlain by basalt flows of Tertiary-Quaternary age. The Singatse Range is an uplifted west-tilted fault block that is bounded by normal faults. The pluton has been disrupted by high-angle normal faults.

Hydrologic setting: The pluton is in Walker Lake ground-water system and drainage is to the West Walker River. Discharge occurs in west and east flanks of the exposures in Smith and Mason Valleys. Water is used in these valleys for irrigation, livestock, and public supply.

Aeromagnetic expression: Most of the granitic rocks are associated with regional low-amplitude positive anomalies in an area of low magnetic relief.

Mining activity: Yerington open pit near outcrops.

Comment: The pluton is located $30 \mathrm{~km}$ southwest of the Walker Lane Fault Zone in an active seismic area west of the Nevada seismic zone. 


\section{L-6. YERINGTON}

General location: Luhr Hill and other unnamed hills east and southeast of Yerington and west of Wassuk Range.

Coordinates: lat $38^{\circ} 59^{\prime} \mathrm{N}$., long $119^{\circ} 05^{\prime} \mathrm{W}$.

Land classification: Public domain, patented mining claims, and some private lands.

Area: $19 \mathrm{~km}^{2}$ (cumulative).

Accessibility: Westernmost outcrop is $2 \mathrm{~km}$ east of State Highway 3 , easternmost outcrop is

$10 \mathrm{~km}$ southwest of the Southern Pacific Railroad.

Remoteness: Westernmost outcrop is $3 \mathrm{~km}$ southeast of Yerington (population 2,010) and the easternmost outcrop is $11 \mathrm{~km}$ east of Yerington.

Geologic setting: The Yerington pluton is composed of Cretaceous granite porphyry, quartz monzonite, and granodiorite. The pluton intrudes Triassic-Jurassic metavolcanic and metasedimentary rocks and is overlain by rhyolitic volcanic rocks of Tertiary age.

The major structure consists of the Walker Lane Fault Zone, located approximately $10 \mathrm{~km}$ east of the pluton. High-angle normal faults of Tertiary age are the predominant structure in the vicinity of the pluton.

Hydrologic setting: The pluton is in the Walker Lake ground-water system, and runoff drains to the Walker River. Discharge occurs in Mason Valley along the west flank of the pluton. Water is used in Mason Valley for irrigation, livestock, and public supply.

Aeromagnetic expression: The easternmost exposure of granitic rocks appears to be associated with a local positive anomaly. The two masses farther to the west have no definite magnetic expression, although the westernmost outcrop occurs on the eastern flank of a negative anomaly. 


\section{L-7. MASON BUTTE}

General location: Mason Butte, northeast of the Singatse Range,

Coordinates: lat $39^{\circ} 05^{\prime}$ N., long $119^{\circ} 09^{\prime} \mathrm{W}$.

Land classification: Private lands.

Area: $1 \mathrm{~km}^{2}$.

Accessibility: $1 \mathrm{~km}$ east of State Highway 3 and $5 \mathrm{~km}$ southwest of the Southern Pacific Railroad.

Remoteness: $9 \mathrm{~km}$ north of Yerington (population 2,010) and $7 \mathrm{~km}$ southeast of Wabuska (population 15).

Geologic setting: The pluton is composed of Cretaceous quartz monzonite and granodiorite.

The granitic exposure is bounded by fine sand, silt, clay of river flood plains, and playa clay and sand of Quaternary age.

No faults of significant size have been mapped in the area; however, the intrusive occurs approximately $15 \mathrm{~km}$ west of the Walker Lane Fault Zone.

Hydrologic setting: The pluton is in the Walker Lake ground-water system and drainage is to the Walker River. The buttes are in the Mason Valley discharge area. Water is used in the valley for irrigation, livestock, and public supply.

Aeromagnetic expression: The granitic rock exposure occurs in the northwestern part of a broad positive anomaly nose of uncertain origin.

Comment: The granitic intrusive occurs within a seismically active area west of the Nevada seismic zone and approximately $15 \mathrm{~km}$ west of the Walker Lane Fault Zone. 
L-8. LONG VALLEY

General location: Southeast flank of the Desert Mountains near Long Valley.

Coordinates: lat $39^{\circ} 05^{\prime}$ N., long 118 $48^{\prime} \mathrm{W}$,

Land classification: Walker River Indian Reservation.

Area: $4 \mathrm{~km}^{2}$ (cumulative).

Accessibility: $10 \mathrm{~km}$ northeast of State Highway 3 (U.S. Highway $95 \mathrm{Alt}$, ) and $1 \mathrm{~km}$ west of U.S. Highway 95.

Remoteness: $32 \mathrm{~km}$ northeast of Yerington (population 2,010).

Geologic setting: The pluton is composed of two exposures of Cretaceous quartz monzonite and granodiorite. The granitic bodies are overlain by andesitic and rhyolitic volcanic rocks of Tertiary age.

The pluton is located within the Walker Lane Fault Zone. The structure near the pluton consists of high-angle normal faults of Tertiary age.

Hydrologic setting: The pluton is in the Walker Lake ground-water system and drainage goes to Walker River via Long Valley tributary. The nearest discharge is $10 \mathrm{~km}$ southwest in Weber Reservoir on the Walker River. Water is used in the area for irrigation, livestock, and domestic purposes.

Aeromagnetic expression: The plutonic rocks occur on the southeastern flank of an elongate, northwest-trending, high-amplitude positive anomaly; the inferred anomaly source is similar plutonic rocks. The maximum areal extent of the inferred buried source is about $25 \mathrm{~km}^{2}$.

Comment: The pluton is located in an active seismic area, west of the Nevada seismic zone and within the Walker Lane Fault Zone. 


\section{L-9. DESERT MOUNTAINS}

General location: South flank of the Desert Mountains:

Coordinates: lat $39^{\circ} 13^{\prime} \mathrm{N}$., long $119^{\circ} 03^{\prime} \mathrm{W}$.

Land classification: Public domain.

Area: Less than $1 \mathrm{~km}^{2}$.

Accessibility: $11 \mathrm{~km}$ east of State Highway 2B (U,S. Highway $95 \mathrm{Alt}$.) and $9 \mathrm{~km}$ north of the Southern Pacific Railroad.

Remoteness: $10 \mathrm{~km}$ northeast of Wabuska (population 15) and $25 \mathrm{~km}$ northeast of Yerington (population 2,010).

Geologic setting: The pluton is composed of Cretacejus quartz monzonite and granodiorite, and intrudes Triassic-Jurassic inetavolcanic rocks. Other rock types in the vicinity of the granitic exposure include andesitic and sedimentary rocks of Tertiary age and basalt flows of Tertiary-Quaternary age. The pluton occurs within the Walker Lane Fault Zone. The predominant mapped structure in the area consists of high-angle normal faults.

Hydrologic setting: The pluton is in the Walker Lake ground-water system. Drainage goes to the Walker River and the nearest discharge is $6 \mathrm{~km}$ southwest in Mason valley. Water is used in the valley for livestock, irrigation, and public supply.

Aeromagnetic expression: An oval, low-amplitude, short-wavelength positive anomaly is centered just southeast of the outcrop of granitic rocks and is presumably caused by these rocks. A maximum areal extent of $1 \mathrm{~km}^{2}$ is inferred for the buried part of the pluton.

Comments: The pluton is located within the Walker Lane Fault Zone in a seismically active area west of the Nevada seismic zone. The Lahontan Reservoir is located $15 \mathrm{~km}$ north of the pluton. 
L-10. CHURCHILL BUTTE

General location: Churchill Butte, southwest of the Lahontan Reservoir.

Coordinates: lat $39^{\circ} 20^{\prime}$ N., long $119^{\circ} 16^{\prime}$ W.

Land classification: Public domain.

Area: $3 \mathrm{~km}^{2}$.

Accessibility: $2 \mathrm{~km}$ north of State Highway $2 \mathrm{~B}$ and $4 \mathrm{~km}$ south of U.S. Highway 50.

Remoteness: $9 \mathrm{~km}$ southwest of Silver Springs (population 220),26 km northeast of Dayton

(population 250), $20 \mathrm{~km}$ southeast of Wabuska (population 15), and $38 \mathrm{~km}$ north of Yerington (population 2,010).

Geologic setting: The pluton is composed of Cretaceous quartz monzonite and granodiorite

and intrudes Triassic-Jurassic metasedimentary rocks, and is overlain

by andesitic volcanic rocks of Tertiary age. Basalt flows of Tertiary-

Quaternary age are common near the granitic exposure.

The granitic intrusive is approximately $7 \mathrm{~km}$ southwest of the Walker Lane

Fault Zone. The structure near the intrusive consists of high-angle

normal faults of Tertiary age.

Hydrologic setting: The pluton is in the Carson River Basin ground-water system. Runoff drains mainly to the Carson River and the nearest discharge goes into the river, $3 \mathrm{~km}$ south. Water is used in the valley for irrigation, livestock, and domestic purposes.

Aeromagnetic expression: The granitic rocks occur on the southern flank of a conspicuous regional negative anomaly, presumably not related to the rocks.

Comments: The granitic intrusive is located approximately $7 \mathrm{~km}$ southwest of the Walker Lane

Fault Zone in a seismically active area west of the Nevada seismic zone. The Lahontan Reservoir is located $8 \mathrm{~km}$ northeast of the intrusive. 


\section{CHURCHILL COUNTY}

\section{GEOLOGY}

Churchi11 County (fig. 11), in west-central Nevada, can be divided into two separate topographic units. The western half of the county is dominated by relatively low relief, encompassing the Carson Sink, which is underlain by Pleistocene sediments of Lake Lahontan. The eastern part of county is marked by northeast-trending mountain ranges, separated from one another by intervening graben valleys or by low east-west divides.

Lithologically, the county is bounded on the east by Paleozoic rocks and on the west by Mesozoic rocks. The Paleozoic assemblage consists of chert, greenstone, and clastic and volcanic rocks that are mainly exposed along the eastern border of the county. Pre-Tertiary rocks exposed throughout the county, with the exception of granitic plutons, are largely Middle Triassic to Middle Jurassic in age. The Mesozoic sedimentary units consist chiefly of a shallow-water facies of conglomerate, sandstone, shale, limestone, and dolomite and an offshore facies of dolomite, limestone, and subordinate clastic rocks. At several places these rocks are metamorphosed. The degree of metamorphism generally depends on proximity to intrusive masses.

Most of the granitic rocks found within the county have been assigned a Cretaceous(?) age. The only pluton assigned a Tertiary age is exposed on the east side of the Stillwater Range. The granitic intrusives are chiefly granodiorite and quartz monzonite in composition.

Historic faults in western Nevada, north of Walker Lake, occur within a well-defined north-trending arcuate linear zone known as the "Churchill arc" (Shawe, 1965). Many of these faults occur along the margins of the large grabens constituting Dixie and Pleasant Valleys (in Pershing County) and their northern extensions. Fault movements within the arc indicate a gradual change from predominantly strike-slip at the southern end (near the Walker Lane Fault Zone) to mainly dip-slip at the northern end (near the northern county line). In 1954, several earthquakes occurred within the county that resulted in considerable damage to manmade structures in the Fallon area and in surface fault scarps near Stillwater and in the Dixie Valley-Fairview Peak area. Central Churchill County also is within a major narrow zone of high seismicity and recent faulting, which extends from Owens Valley (in California) to Winnemucca (in Humboldt County), termed the Nevada seismic zone (Gumper and Scholz, 1971). Much of the geologic information supplied in this compilation has been synthesized from: Willden and Speed, 1974.

HYDROLOGY

The west-central part of Churchill County drains to the Carson Sink and contiguous lowlands, which cover about one-third of the county. The vast Humboldt River drainage basin terminates in the White Plains-Humboldt Sink area of central northwestern Churchill County. The northwestern corner of the county drains southwestward into Bradys Hot Springs area, and southwestern Churchill County drains southward into Rawhide Flats. Dixie Valley and Edwards Creek Valley drain the eastern third of the county, and each of these basins is topographically and hydrologically closed. Dixie Valley drainage basin includes Fairview Valley and adjacent small valleys in southeastern Churchill Courity. 


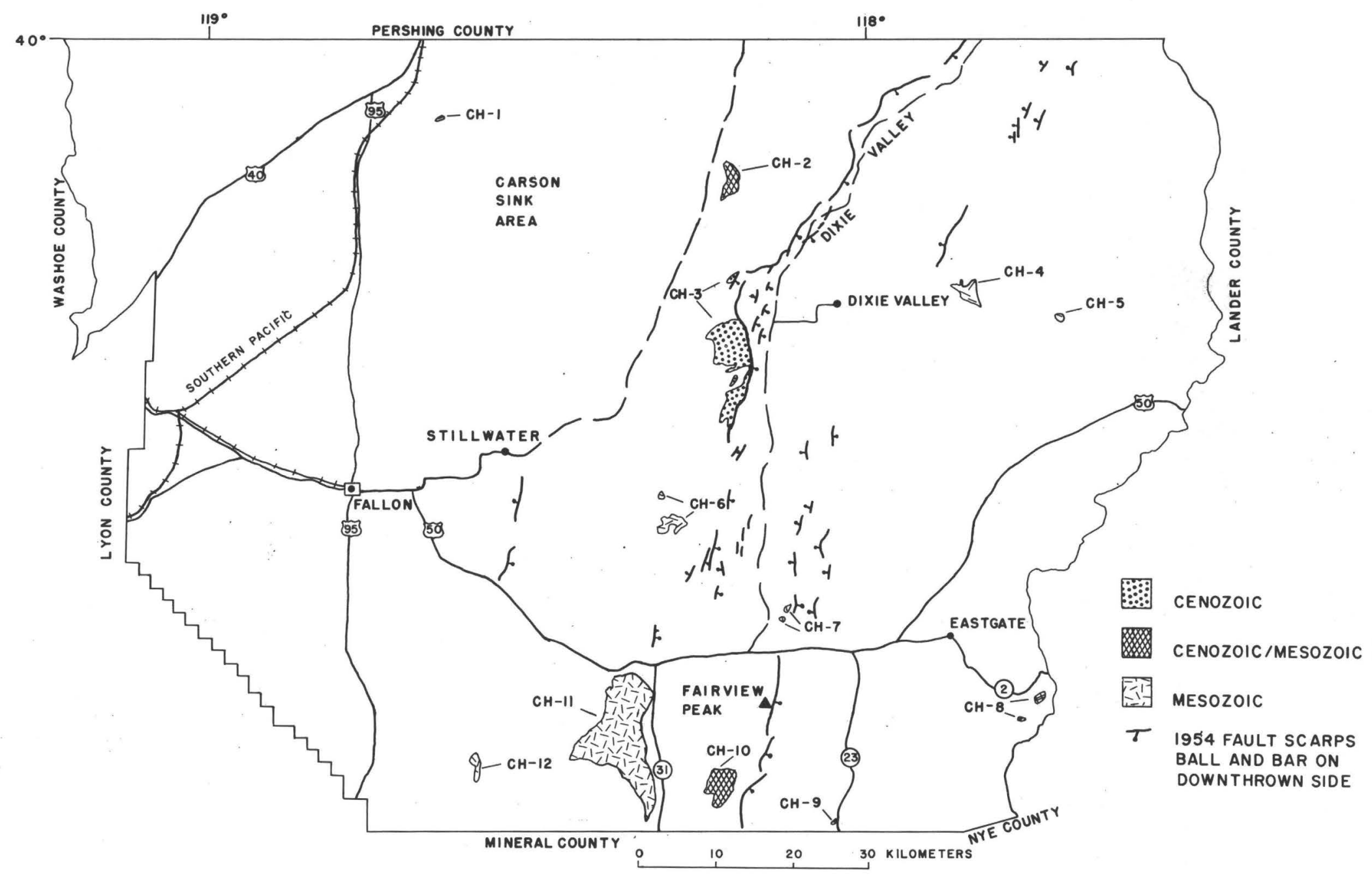

FIGURE 11.-- LOCATIONS OF PLUTONS IN CHURCHILL COUNTY 
The principal sources of runoff and recharge within Churchill County are the Stillwater Range and Clan Alpine and Desatoya Mountains.

The Carson River Basin ground-water system underlies its drainage area (including Carson Sink) and receives subsurface flow from the Fernley area, to the west partly in southeastern Washoe County, and also some inflow from the terminus of the Humboldt system to the northwest. The Rawhide Flats ground-water system may receive a minor amount of subsurface inflow from the Carson River Basin system; it is otherwise hydrologically closed. The Dixie Valley groundwater system receives influx from Jersey Valley, to the northeast, and the Fairview Valley complex that includes the chain of small valleys east of Fairview to the eastern county line. Edwards Creek Valley ground-water system underlies its drainage area in east-central Churchill County and the system is hydrologically closed.

The hydrology of Churchill County was taken mainly from the following references:

Cohen and Everett, 1963; Glancy and Katzer, 1976; Everett, 1964. 
CH-1. TOPOG PEAK

General location: Southwest part of West Humboldt Range in northwestern part of county. Coordinates: lat $39^{\circ} 54^{\prime} \mathrm{N}$., long $118^{\circ} 39^{\prime} \mathrm{W}$.

Land classification: Private and Bureau of Reclamation withdrawals of public domain.

Area: Less than $1 \mathrm{~km}^{2}$.

Accessibility: The Southern Pacific Railroad and U.S. Highway 95 are $6 \mathrm{~km}$ and $9 \mathrm{~km}$ west of the outcrop. U.S. Highway 40 intersects U.S. Highway 95 northwest of the area.

Remoteness: The towns of Lovelock (Pershing County, population 1,571) and Fallon (population $2,959)$ lie $33 \mathrm{~km}$ north and $49 \mathrm{~km}$ south of the intrusive, respectively.

Geologic setting: A small exposure of medium-grained quartz monzonite and granodiorite(?) occurs approximately $0.5 \mathrm{~km}$ north of Topog. Peak. Radiometric age determination on biotite indicates an age of $75.9 \pm 1.5 \mathrm{~m} . \mathrm{y}$. (Speed and Armstrong, 1971), placing it in Late Cretaceous time.

The stock intrudes Lower Jurassic calcareous siltstone and Timestone. Pervasive low-grade metamorphism surrounding the body suggests a widespread distribution of granite in the shallow subsurface.

Hydrologic setting: The pluton is in the Humboldt River ground-water system, and runoff drains to the White Plains-Humboldt Sink area--the termination of the river's flow. The pluton is at the edge of the discharge area, and the water is used primarily for irrigation, livestock, and domestic purposes.

Aeromagnetic expression: The granitic rocks occur at the northeastern extremity of a shortwavelength high-amplitude positive anomaly having an unknown source.

Comment: The West Humboldt Range forms a divide between the Humboldt Sink on the west and the Carson Sink on the east.

Selected reference: Speed and Armstrong, 1971. 
CH-2. WHITE CLOUD CANYON

General location: Western flank of the Stillwater Range in northern part of county.

Coordinates: lat $39^{\circ} 50^{\prime} \mathrm{N}$. , long $118^{\circ} 12^{\prime} \mathrm{W}$.

Land classification: Public domain and patented mining claims.

Area: $8 \mathrm{~km}^{2}$.

Accessibility: A gravel road flanks the west side of the Stillwater Range and passes $2 \mathrm{~km}$ west of the outcrop. A paved road extends to the town of Stillwater $44 \mathrm{~km}$ southwest of the exposure.

Remoteness: The outcrop is $42 \mathrm{~km}$ southeast of Lovelock (Pershing County, population 1,571) and $61 \mathrm{~km}$ northeast of Fallon (population 2,959).

Geologic setting: The pluton has been described as a slightly micaceous granite, intruded by many granite porphyry and diorite porphyry dikes. The intrusive of Cretaceous(?) age intrudes a sequence of limestone and calcareous shale and some thin gypsum beds, all mapped as Late Triassic in age. At several localities surrounding the pluton, small klippen of massive limestone, marble, and intercalated quartz arenite of Jurassic age rest upon Upper Triassic strata. One such klippe has been cut by the intrusive body along the southernmost tip of the exposure.

Hydrologic setting: The pluton is in the Carson Sink ground-water system and drainage basin.

The nearest significant discharge is $21 \mathrm{~km}$ southwest into Stillwater Marsh, where the water is used for wildlife, recreation, and irrigation purposes.

Aeromagnetic expression: No single, well-defined anomaly is associated with the exposed granitic rocks.

Mining activity: Gold, silver, and tungsten mines are active (1976) within the contact metamorphic aureole surrounding the pluton, known as the White Cloud mining district.

Comment: Late Quaternary fault scarps have been mapped along the eastern and western fronts of the Stillwater Range. Current tectonic activity in the area is also indicated by a high concentration of earthquake epicenters within this zone of historic faulting. 


\section{CH-3. IXL CANYON}

General location: Eastern flank of the Stillwater Range.

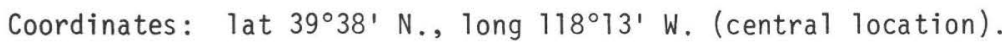

Land classification: Public domain.

Area: $41 \mathrm{~km}^{2}$ (cumulative).

Accessibility: A gravel road, intersecting U.S. Highway $50,29 \mathrm{~km}$ south of the main exposure, extends along the western side of Dixie Valley and passes $2 \mathrm{~km}$ east of the intrusive body.

Remoteness: The small town of Dixie Valley is located $13 \mathrm{~km}$ east of the predominant intrusive body. The town of Fallon lies $50 \mathrm{~km}$ to the southwest.

Geologic setting: The composite pluton is located in and adjacent to IXL Canyon. The body is mainly composed of fine- to coarse-grained quartz monzonite, dated as 28 -2 m.y. (Speed and Armstrong, 1971). Tertiary rhyolite, rhyodacite, and latite welded tuffs, basalt, and andesite were the predominant rock types intruded and metamorphosed by the Tertiary granitic rocks. However, the small northern exposure and the northern border of the main intrusive are in contact with undivided shale, sand, and siltstone of Late Triassic age.

The major structures in the vicinity of the two exposures of granitic rocks are high-angle oblique-slip faults, marking the boundary between the granite and the alluvium in Dixie Valley. These faults were reactivated during the Dixie Valley-Fairview Peak earthquakes of December 16, 1954.

Hydrologic setting: The pluton is in the Dixie Valley ground-water system and drainage basin: The nearest discharge is $8 \mathrm{~km}$ east, where the water is used for irrigation, domestic, and livestock purposes.

Aeromagnetic expression: The granitic rocks occur on the northern and eastern flanks of a north-trending high-amplitude positive anomaly, presumably underlain by similar rocks. The maximum areal extent of the inferred buried source is about $25 \mathrm{~km}^{2}$.

Mining activity: Mining is currently (1976) inactive within the IXL district. In the past, small claims have been worked in a discontinuous contact metamorphic zone in Triassic limestone.

Comment: A high concentration of earthquake epicenters has been documented along the western margin of Dixie Valley.

Selected reference: Speed and Armstrong, 1971. 


\section{CH-4. MEADOW SPRINGS}

General location: Western flank of the Clan Alpine Mountains in northern half of the county. Coordinates: lat $39^{\circ} 42^{\prime}$ N., long $117^{\circ} 51^{\prime} \mathrm{W}$.

Land classification: Public domain.

Area: $6 \mathrm{~km}^{2}$.

Accessibility: The nearest maintained road in the vicinity of the intrusive is the gravel road extending along the west side of Dixie Valley $23 \mathrm{~km}$ west of the exposure.

Remoteness: The outcrop occupies an area $74 \mathrm{~km}$ southeast of Lovelock (Pershing County, population 1,571), $83 \mathrm{~km}$ northeast of Fallon (population 2,959), and $69 \mathrm{~km}$ northwest of Austin (Lander County, population 300).

Geologic setting: The pluton, composed of granodiorite and quartz monzonite, intrudes siltstone and intercalated sandstone of Late Triassic age. Along the southern and northern borders the intrusive is overlain by Tertiary basalts and andesites. A potassium-argon age determination indicates an age of $103^{+} 2$ m.y. (Speed and Armstrong, 1971).

At several localities high-angle faults mark the boundaries between the intrusive and the surrounding rock types mentioned above.

Hydrologic setting: The pluton is in the Dixie Valley ground-water system and drainage basin. The nearest discharge is $14 \mathrm{~km}$ west and water is used in Dixie Valley for irrigation, domestic, and livestock purposes.

Aeromagnetic expression: The granitic rocks occur at the northern flank of a north-northeasttrending, elongate, high-amplitude, positive anomaly, which may be caused by similar rocks at depth. The maximum areal extent of the buried source is about $75 \mathrm{~km}^{2}$.

Mining activity: Antimony mining is active (1976) several kilometers north of the outcrop.

Comments. Fault scarps, mapped in the alluvium about $5 \mathrm{~km}$ northwest of the exposure, are associated with the Dixie Valley-Fairview Peak earthquake of 1954. The area lies within the Nevada seismic zone.

Selected reference: Speed and Armstrong, 1971. 
General location: Eastern flank of the Clan Alpine Mountains.

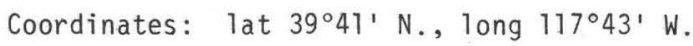

Land classification: Public domain.

Area: $2 \mathrm{~km}^{2}$.

Accessibility: U.S. Highway 50 passes along the east side of Edwards Creek Valley $14 \mathrm{~km}$ southeast of the outcrop.

Remoteness: The town of Austin in Lander County (population 300) is located $58 \mathrm{~km}$ east of the exposure.

Geologic setting: The pluton is predominantly composed of fine- to medium-grained granodiorite. A radiometric determination indicates an age of $87.4-2 \mathrm{~m} . \mathrm{y}$. (Speed and Armstrong, 1971). The intrusive cuts interbedded siltstone, mudstone, sandstone, limestone, and conglomerate (Late Triassic age) except along part of the southern boundary where the body is in fault contact with surficial deposits.

Hydrologic setting: The pluton is in the Edwards Creek Valley ground-water system and drainage basin. The nearest discharge is $7 \mathrm{~km}$ east where the water is used for livestock, domestic, and irrigation purposes.

Aeromagnetic expression: No single, well-defined anomaly is associated with the exposed granitic rocks.

Mining activity: Although the area is currently inactive, scheelite mines were in operation along the contact of granodiorite and Upper Triassic rocks as late as 1961 .

Selected reference: Speed and Armstrong, 1971. 
General location: Southern part of the Stillwater Range.

Coordinates: lat $39^{\circ} 27^{\prime} \mathrm{N}$., long $118^{\circ} 18^{\prime} \mathrm{W}$. (central location).

Land classification: Public domain.

Area: $5 \mathrm{~km}^{2}$.

Accessibility: The main body 1 ies $10 \mathrm{~km}$ west of the Dixie Valley improved road and $17.5 \mathrm{~km}$ north of U.S. Highway 50.

Remoteness: The main outcrop occupies an area $40 \mathrm{~km}$ east of Fallon (population 2,959). Geologic setting: Two exposures of granodiorite of Cretaceous(?) age occur within the Mountain Wells mining district. These outcrops cut shale, sandstone, siltstone, limestone, and dolomite of Triassic age. The country rock generally has been metamorphosed to phyllite and slate along the intrusive contact.

Hydrologic setting: The district is in the Dixie Valley ground-water system and the Fairview Valley tributary drainage basin. The nearest discharge is $29 \mathrm{~km}$ northeast in Dixie Valley, where water is used for irrigation, domestic, and livestock purposes.

Aeromagnetic expression: Although the small northern outcrop of granitic rocks has no welldefined magnetic expression, the larger southern mass is clearly associated with an oval, short-wavelength positive anomaly. The maximum areal extent of this anomaly is estimated to be $1-5 \mathrm{~km}^{2}$.

Comments: Recent high-angle fault scarps associated with the Dixie Valley-Fairview Peak earthquakes of 1954 have been mapped in the alluvium $6 \mathrm{~km}$ southwest of the pluton. The outcrops occur within the Nevada seismic zone. 


\section{CH-7. CHALK MOUNTAIN}

General location: Southeast edge of Dixie Valley.

Coordinates: lat $39^{\circ} 20^{\prime} \mathrm{N}$., long $118^{\circ} 08^{\prime}$ W. (central location).

Land classification: Public domain and local mining claims.

Area: $1 \mathrm{~km}^{2}$.

Accessibility: The Dixie Valley improved road and U.S. Highway 50 are $1.5 \mathrm{~km}$ west and $4 \mathrm{~km}$ south of the southern exposure, respectively.

Remoteness: The Chalk Mountain outcrops are $58 \mathrm{~km}$ southeast of Fallon (population 2,959),

$53 \mathrm{~km}$ northwest of Gabbs (Nye County, population 874), and $93 \mathrm{~km}$ southwest of Austin (Lander County, population 300).

Geologic setting: The exposures of granodiorite of Cretaceous(?) age intrude limestone and dolomite of possible Triassic age and older massive quartz porphyry, which in turn intrudes Triassic sedimentary rocks. Along the southern end of Chalk Mountain, volcanic and sedimentary rocks of Triassic and (or) Jurassic age have been thrust over the carbonates. The carbonate rocks are highly folded, and recent normal faults are abundant.

Hydrologic setting: The pluton is in the Dixie Valley ground-water system and Fairview Valley tributary drainage basin, all closed hydrologically. The nearest discharge is $36 \mathrm{~km}$ north, where water is used for irrigation, domestic, and livestock purposes.

Aeromagnetic expression: The granitic rocks occur on the northern flank of an elliptical positive anomaly nose of uncertain origin.

Mining activity: Mines within the Chalk Mountain district are no longer in operation, but development of lead deposits was reported in the early 1920's.

Comments: Numerous recent fault scarps along surrounding range fronts were mapped after the Dixie Valley-Fairview Peak earthquakes in 1954. Fairview Peak is about $11 \mathrm{~km}$ to the south and lies within the Nevada seismic zone. 
CH-8. EASTGATE MINING DISTRICT

General 1ocation: Southeast part of county near Lander County line.

Coordinates: lat $39^{\circ} 13^{\prime} \mathrm{N}$., long $117^{\circ} 46^{\prime} \mathrm{W}$. (central location).

Land classification: Public domain.

Area: $2 \mathrm{~km}^{2}$ (cumulative).

Accessibility: Main outcrop lies $2 \mathrm{~km}$ southeast of State Highway 2, which intersects U.S.

Highway 50 west of Eastgate.

Remoteness: Main outcrop occurs $13.5 \mathrm{~km}$ southeast of the small town of Eastgate, $42.5 \mathrm{~km}$ northeast of Gabbs (Nye County, population 874), and $64 \mathrm{~km}$ southwest of Austin (Lander County, population 300).

Geologic setting: Two intrusive bodies composed of quartz monzonite occur along the southwestern flank of the Desatoya Mountains. In this area a westward-dipping normal fault has brought quartz monzonite on the east into contact with altered sedimentary deposits and rhyodacites of Miocene age. Metavolcanics of Triassic or Jurassic age are cut by the intrusives. Aplite and pegmatite dikes commonly cut the quartz monzonite.

Hydrologic setting: The district is in the Dixie Valley closed ground-water system and Eastgate Valley upper tributary drainage basin. The nearest discharge is $54 \mathrm{~km}$ northwest, a1though nearer springs may intercept some groundwater flow. Water is used in Dixie Valley for irrigation, domestic, and livestock purposes.

Aeromagnetic expression: The granitic rocks occur on the northern and western flanks of a short-wavelength high-amplitude positive anomaly of uncertain origin. 
CH-9. BELL FLAT

General location: Southeast of Bell Flat near Mineral County line.

Coordinates: lat $39^{\circ} 05^{\prime} \mathrm{N}$. , long $118^{\circ} 03^{\prime} \mathrm{W}$.

Land classification: Public domain.

Area: Less than $1 \mathrm{~km}^{2}$.

Accessibility: State Highway 23 passes along the eastern edge of the exposure.

Remoteness: The towns of Gabbs (Nye County, population 874) and Fallon (population 2,959)

are located $26.5 \mathrm{~km}$ southeast and $76 \mathrm{~km}$ northwest of the exposure, respectively.

Geologic setting: A small circular granodiorite and (or) quartz monzonite body of Cretaceous(?)

age is overlain by undivided volcanic rocks, mainly composed of basalt and andesite of 01 igocene age.

Hydrologic setting: The pluton is in the Gabbs Valley ground-water system and drainage basin.

The nearest discharge is $22 \mathrm{~km}$ southwest, and the water is used in Gabbs Valley mainly for domestic and livestock purposes.

Aeromagnetic expression: There is no magnetic expression associated with the rocks.

Comments: The west side of Bell Flat is marked by several high-angle discontinuous fault

scarps associated with the Dixie Valley-Fairview Peak earthquakes of 1954, one of which had a maximum vertical-slip component of about $3.6 \mathrm{~m}$. Also, the area is

in a zone of high seismicity, denoted as the Nevada seismic zone.

Selected reference: Slemmons, 1957. 
CH-10. SLATE MOUNTAIN

General location: Southeastern part of county near the Mineral County line.

Coordinates: lat $39^{\circ} 08^{\prime} \mathrm{N}$., long $118^{\circ} 14^{\prime} \mathrm{W}$.

Land classification: Public domain.

Area: $14 \mathrm{~km}^{2}$.

Accessibility: The intrusive occurs $5.5 \mathrm{~km}$ east of State Highway 31.

Remoteness: The pluton is $59 \mathrm{~km}$ southeast of Fallon (population 2,959), $53 \mathrm{~km}$ northeast of

Schurz (Mineral County, population 300), and $37 \mathrm{~km}$ northwest of Gabbs (Nye County, population 874).

Geologic setting: The central part of Slate Mountain contains a complex of Cretaceous(?) porphyritic quartz monzonite and granodiorite cut by abundant aplite dikes. The complex has intruded metamorphosed volcanic, clastic rock, and 1 imestone of Triassic and Jurassic age. These rocks are strongly foliated tangentially to the trace of the granitic pluton. Rhyolites, basalts, and andesites overlie the intrusive along the northern, western, and southern edges. These contacts have been mapped partly as faults and partly as unconformities.

Hydrologic setting: The pluton is in Dixie Valley ground-water system and Fairview Valley tributary drainage basin. The nearest significant discharge is $59 \mathrm{~km}$ northward in Dixie Valley, although wells at Frenchman, $16 \mathrm{~km}$ north, may intercept some of the ground-water flow. The water is used in the area for irrigation, domestic, and livestock purposes.

Aeromagnetic expression: The granitic rocks occur on the southwestern flank of a positive anomaly nose of uncertain origin.

Comments: Recent fault scarps have been mapped in Bell Flat east of Slate Mountain. Slate Mountain also is within an area of high concentrations of historic earthquake epicenters within the Nevada seismic zone. 
General location: Northern half of Sand Springs Range in southern part of county. Coordinates: lat $39^{\circ} 11^{\prime} \mathrm{N}$. , long $118^{\circ} 23^{\prime} \mathrm{W}$.

Land classification: Parts of the exposure are designated as public domain, U.S. Navy bombing target area, and Department of Energy (formerly U.S. Atomic Energy

Area: $98 \mathrm{~km}^{2}$. Commission) land.

Accessibility: U.S. Highway 50 flanks the northern edge of the pluton and State Highway 31 passes along the western side of Fairview Valley less than $2 \mathrm{~km}$ east of the outcrop.

Remoteness: The exposures are $42 \mathrm{~km}$ southeast of Fallon (population 2,959), $29 \mathrm{~km}$ northeast of Schurz (Mineral County, population 300), and $43 \mathrm{~km}$ northwest of Gabbs (Nye County, population 874).

Geologic setting: The pluton, which underlies most of the Sand Springs Range in Churchill County, is a composite body of granite, granodiorite, and quartz monzonite radiometrically dated as $79.6-2 \mathrm{~m} . \mathrm{y}$. (Schilling, 1965). The intrusive is cut by a series of aplite and pegmatite dikes that extend along the western crest of the range. A system of andesite dikes trending northwestward in the north and northeastward in the south cuts the complex and bordering metamorphic rocks. In turn, the andesite dikes are cut by a series of younger rhyolite dacite dikes.

Along the northern and southern boundaries, the pluton is in contact with volcanic siltstone, mudstone, silty tuff, and abundant limestone (Upper Triassic to Middle Jurassic). The immediate borders have been metamorphosed to hornfels and schists. These Mesozoic rocks also show pervasive folding and thrusting.

Faults associated with recent earthquakes have not been mapped along the range front as in surrounding ranges.

Hydrologic setting: The pluton is in the Carson River Basin and Dixie Valley ground-water systems, and runoff drains to the northwest to Salt Wells Basin and to the northeast to Fairview Valley. The nearest discharge is $12 \mathrm{~km}$ northwest where water is used for industrial purposes. Discharge also occurs at Frenchman, $13 \mathrm{~km}$ northeast in Fairview Valley, where the water is used mainly for domestic purposes.

Aeromagnetic expression: The pluton is associated largely with a low-amplitude positive anomaly whose gradient steepens near the southwestern contact of the body. The pronounced northwest-trending anomaly near this contact may be associated with andesitic and associated volcanoclastic rocks.

Comments: The metamorphic structures of Slate Mountain are analogous in type and orientation to those in the southern Sand Springs Range, suggesting the granitic bodies may be contiguous beneath Fairview Valley. The area occurs within the Nevada seismic zone.

Selected reference: Schilling, 1965. 


\section{CH-12. BARNETT HILLS}

General location: Southwestern part of the county, southeast of Fallon.

Coordinates: lat $39^{\circ} 09^{\prime} \mathrm{N}$., long $118^{\circ} 36^{\prime} \mathrm{W}$.

Land classification: Public domain and Walker River Indian Reservation.

Area: $2 \mathrm{~km}^{2}$.

Accessibility: The outcrop is located about $13 \mathrm{~km}$ east of U.S. Highway 95.

Remoteness: Barnett Hills is $38 \mathrm{~km}$ southeast of Fallon (population 2,959) and $40 \mathrm{~km}$ northeast of Schurz (Mineral County, population 300).

Geologic setting: Cretaceous(?) exposures of granodiorite occur along the northwest flank of the Barnett Hills. The intrusive is largely overlain by Tertiary units that include a rhyolite unit of Miocene age, and basalt and andesite units of late Miocene and Pliocene age.

Hydrologic setting: The pluton is in the Rawhide Flats ground-water system and drainage basin, both hydrologically closed. The nearest discharge point is $9 \mathrm{~km}$ west and the water is used for irrigation, domestic, and livestock purposes.

Aeromagnetic expression: The granitic rocks occur at the eastern margin of a northwest-trending high-amplitude short-wavelength positive anomaly, which appears to be caused in large part by basaltic rocks.

Comments: Earthquakes of Ju1y 6, 1954, and August 23, 1954, resulted in movement along a fault near the eastern border of Rainbow Mountain (Tocher, 1956) about $27 \mathrm{~km}$ north of the intrusive. The area occurs within a zone of high seismic activity, denoted as the Nevada seismic zone.

Selected reference: Tocher, 1956. 
GEOLOGY

Lander County (fig. 12) is located in central and north-central Nevada and is made up of north-northeast-trending mountain ranges separated by wide basins.

The county is underlain by rocks of sedimentary, igneous, and metamorphic origin from Early Cambrian to Holocene in age. The lower Paleozoic sediments were deposited in the Cordilleran geosyncline and are broken into two assemblages: (1) carbonate or eastern assemblage that forms the eastern (miogeosyncline) part of the geosyncline and consists of limestone and dolomite and minor shale and quartzite; and (2) siliceous and volcanic or western assemblage that forms the western (eugeosyncline) part of the geosyncline and consists of chert, clastic sedimentary, intercalated volcanic, and pyroclastic rocks.

The lower Paleozoic rocks were folded and faulted during Late Devorian and Early Mississippian time as part of the Antler orogeny (Stewart and others, 1977); siliceous and volcanic rocks have been thrust eastward over carbonate rocks. The axis of the Antler orogeny lies near Lander County, where, by Middle Pennsylvanian time, the orogenic belt had been eroded, depositing the clastic material in troughs and resulting in sedimentary rocks ranging in age from Pennsylvanian to Permian.

Mesozoic rocks are represented in the county by deposits derived from local uplifts and consist of coarse clastic rocks and 1 imestones. Other Mesozoic rocks include plutonic rocks of Jurassic and Cretaceous age composed mostly of quartz monzonite and granodiorite.

Tertiary rocks consist mostly of volcanic types, with intrusive and sedimentary rocks less common. Volcanic rocks include tuffs, lavas, and breccias that range from rhyolite to basalt in composition and represent different events in Tertiary time.

Lander County has been affected by several major orogenic episodes (Stewart and others, 1977): (1) Antler orogeny (Late Devonian to Early Mississippian), during which a thick assemblage of siliceous and volcanic rocks was transported from west to east along the Roberts Mountains Thrust; a carbonate assemblage forms the lower plate of this thrust; (2) the Sonoma orogeny (Late Permian and Early Triassic) during which the area was subjected to folding and faulting of rocks. One of the major structures that developed is the Golconda Thrust that transported the siliceous and volcanic assemblage eastward; and (3) Basin and Range deformation (Tertiary and Quaternary) consisting of high-angle normal faults bounding uplifted faultblock mountain ranges trending east-northeast, resulting in the present topography of the county.

The Oregon-Nevada lineament (p1.4) is located in the northeastern part of the county. The lineament consists of closely spaced, partly en echelon faults extending from Oregon into Nevada. The lineament is defined by faults, voluminous lava domes and flows of Miocene age, and a conspicuous linear aeromagnetic anomaly (Stewart and others, 1975). The segment of the lineament in Nevada is composed of closely spaced north-northwest-trending faults. The northwest-trending fault zones that define the lineament are segmented by northeast-trending basin-and-range faults (Stewart and others, 1975). The Oregon-Nevada lineament has been interpreted to be the surface expression of a deep-seated fracture zone that may have a complex history of strike-slip and tensional movement (Stewart and others, 1975). 


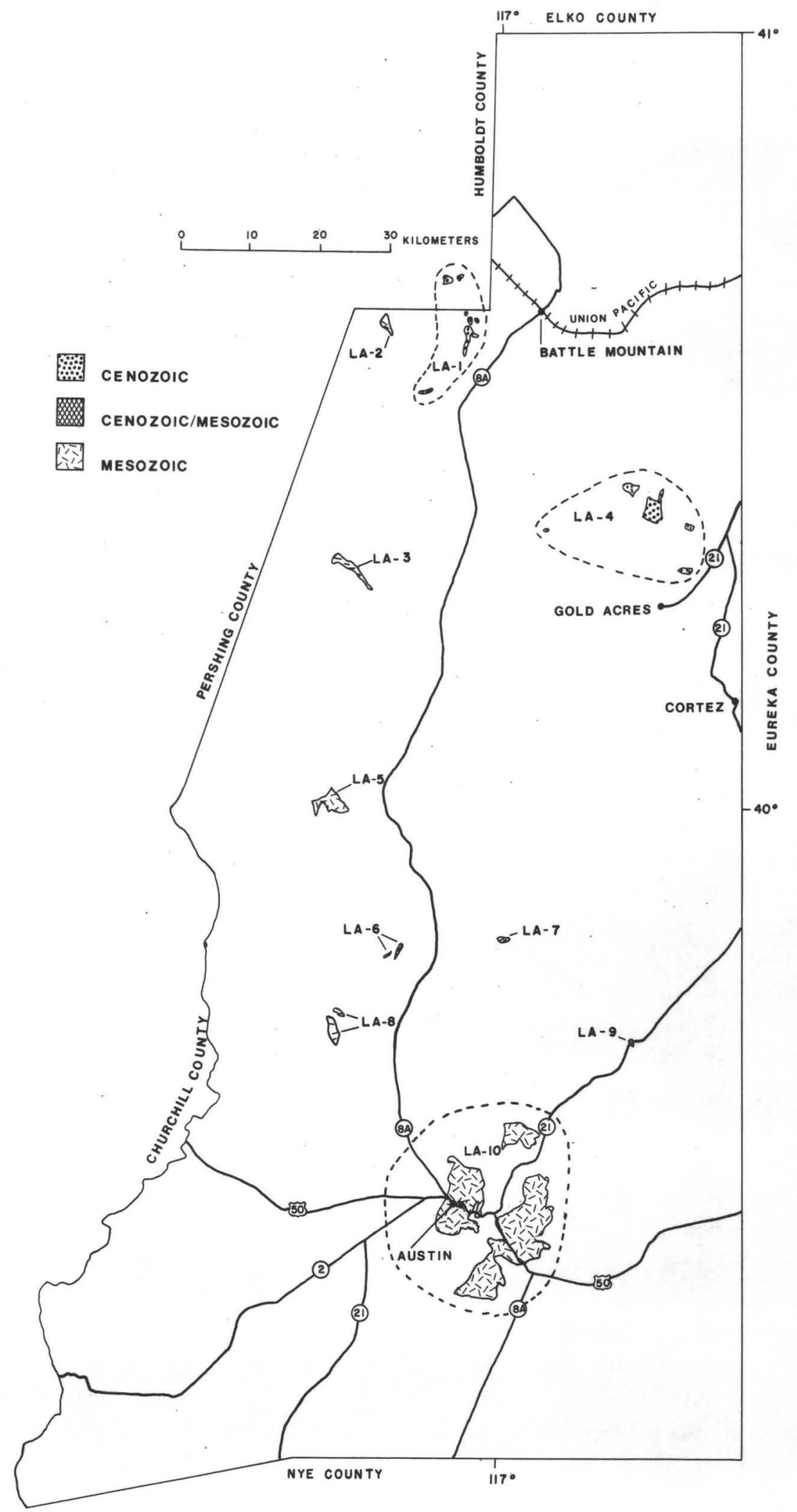

FIGURE 12.-- LOCATIONS OF PLUTONS IN LANDER COUNTY 
The geologic data were extracted and summarized from the following:

Stewart, McKee, and Stager, 1977; Stewart, Walker, and Kleinhampl, 1975.

HYDROLOGY

The Humboldt River Basin drains most of Lander County, with its major tributaries Reese River and Carico Lake-Crescent Valleys. The Sheep Creek Range, in the northern end of the county, drains directly into that part of the Humboldt River passing through the northern part of the county near the town of Battle Mountain. Big Smoky Valley in the south drains the central southeastern part of Lander County; Monitor Valley drains, in a northerly direction, the southeasternmost part of the county. Smith Creek, Buffalo, and Grass Valleys are closed; they are individual drainage basins largely within Lander County.

Major sources of runoff and recharge are parts of Toiyabe and Toquima Ranges, and the Simpson Park Desatoya and Shoshone Mountains. Other individual peaks that reach altitudes above 1,980 m such as Battle Mountain, furnish minor amounts of recharge to aquifers.

The Humboldt River Basin ground-water system moves underflow parallel to surface runoff in the tributary valleys as well as in the main Humboldt River Valley. Ground water from Buffalo Valley feeds into the Reese River tributary area. Smith Creek Valley, Grass Valley and the northern part of Big Smoky Valley have hydrologically closed ground-water systems. Monitor Valley ground-water system features northerly regional movement in accord with its surface drainage.

The hydrology of Lander County was taken largely from the following references:

Crosthwaite, 1963; Eakin and Lamke, 1966; Eakin, Moore, and Everett, 1965; Everett and Rush, 1966; and Rush and Schroer, 1970. 


\section{LA-1. COPPER CANYON STOCK}

General location: East flank of Battle Mountain, with northernmost outcrops overlapping into Humboldt County.

Coordinates: Tat $40^{\circ} 36^{\prime} \mathrm{N}$., long $117^{\circ} 02^{\prime} \mathrm{W}$.

Land classification: Private and public domain, with some patented mining claims.

Area: $6 \mathrm{~km}^{2}$.

Accessibility: Major southern outcrops $4 \mathrm{~km}$ west of State Highway 8A, and northern outcrops

$5 \mathrm{~km}$ southwest of Southern Pacific Railroad tracks.

Remoteness: Major southern outcrops $10 \mathrm{~km}$ southwest of Battle Mountain (population 1,856) and northern outcrops $12 \mathrm{~km}$ northwest of Battle Mountain.

Geologic setting: The pluton is composed of Jurassic to Tertiary granodiorite and quartz monzonite. The pluton intrudes the following: Cambrian Harmony Formation, composed of sandstone, shale, and minor limestone; Pennsylvanian-Permian Pumpernickel Formation, composed of chert, siltstone, and pyroclastics, and the Antler sequence, which includes limestones, sandstones, shales, and conglomerates of Pennsylvanian-Permian age. Tertiary ash-flow tuffs and basalt flows occur locally. Parts of the pluton have been dated as $38.2 \pm 0.8$ and $38.5 \pm 0.8$ m.y. (Silberman and McKee, 1971).

The younger Harmony Formation has been thrust over the older (Cambrian) Scott Canyon Formation near vicinity of granitic intrusive. Northnortheast-trending high-angle normal faults are also present.

Hydrologic setting: The pluton is in the Humboldt River Basin ground-water system and drainage basin. The nearest discharge is $11 \mathrm{~km}$ northeast where water is used for irrigation, domestic, and public supply purposes.

Aeromagnetic expression: The main granitic rock exposure occurs on the northeastern flank of a high-amplitude positive anomaly, which presumably has a subsurface source of similar rocks. The maximum areal extent of the buried source is about $15 \mathrm{~km}^{2}$.

Mining activity: Copper and gold mining along eastern and southeastern flanks of Battle Mountain.

Selected references: Silberman and McKee, 1971 ; Theodore, Silberman, and Blake, 1973. 
General 1ocation: West flank of Battle Mountain at Trenton Canyon.

Coordinates: lat $40^{\circ} 37^{\prime} \mathrm{N}$, , Tong $117^{\circ} 08^{\prime} \mathrm{W}$.

Land classification: Private and public domain.

Area: $2 \mathrm{~km}^{2}$.

Accessibility: $14 \mathrm{~km}$ northwest of State Highway $8 \mathrm{~A}$.

Remoteness: $21 \mathrm{~km}$ west of Battle Mountain (population 1,856),

Geologic setting: The pluton is composed of Cretaceous granodiorite and intrudes the

following: Pennsylvanian-Permian Pumpernickel Formation, composed of chert and siltstone, Havallah Formation composed of shale, sandstone, chert, and limestone, and the Antler sequence that includes limestones, sandstones, shales, and conglomerates. The pluton has been dated as $87.0 \pm 1$ and 87.2 m.y. (Silberman and McKee, 1971).

The Havallah Formation has been thrust from the west over the Antler sequence. North-northeast-trending high-angle normal faults are common in the area.

Hydrologic setting: The pluton is in the Humboldt River Basin ground-water system. Runoff drains to Buffalo Valley, which is topographically closed. The nearest discharge is $17 \mathrm{~km}$ south in the Reese River plain, where water is used for livestock and domestic purposes.

Aeromagnetic expression: The granitic rocks occur on the steep northern gradient of a highamplitude positive anomaly; subsurface equivalents presumably serve as the anomaly source. The maximum and areal extent of the inferred source is estimated to be $15 \mathrm{~km}^{2}$.

Mining activity: Copper and gold mining along the eastern and southeastern flanks of Battle Mountain.

Selected reference: Silberman and McKee, 1971. 


\section{LA-3. MC COY STOCK}

General location: Northern part of the Fish Creek Mountains:

Coordinates: lat $40^{\circ} 18^{\prime} \mathrm{N}$, , long $117^{\circ} 15^{\prime} \mathrm{W}$.

Land classification: Public domain.

Area: $4 \mathrm{~km}^{2}$.

Accessibility: $11 \mathrm{~km}$ west of State Highway $8 \mathrm{~A}$.

Remoteness: $45 \mathrm{~km}$ southwest of Battle Mountain (population 1,856).

Geologic setting: The pluton is composed of Jurassic to Tertiary granodiorite and quartz monzonite, with some granite, alaskite, and diorite. The pluton has been dated as 153-3 m.y. (Silberman and McKee, 1971). The pluton intrudes the Triassic Cane Spring Formation, composed of sandstone and minor amounts of 1 imestone, shale, and conglomerate, and the Osobb Formation, which includes limestone, dolomite, sparse shale, and conglomerate. The pluton is overlain unconformably by Tertiary ash-flow tuffs (Caetano Tuff, Bates Mountain Tuff, and Fish Creek Mountains Tuff). The exposed structure consists of northeast- and northwest-trending highangle normal faults.

Hydrologic setting: The pluton is in the Humboldt River Basin ground-water system. Runoff drains to Reese River and Buffalo Valley. The nearest discharge is $12 \mathrm{~km}$ east into Reese River, where water is used for livestock, domestic, and irrigation purposes.

Aeromagnetic expression: A west-trending positive anomaly transects the northwest-trending outcrop pattern of granitic rocks. This anomaly, as well as one immediately north of the exposure, appears to be in large part attributable to extrusive rocks.

Comment: The north Fish Creek porphyry copper prospect exists $10 \mathrm{~km}$ north of the stock at the extreme north end of the Fish Creek Mountains.

Selected references: Miller and Silberman, 1977; Silberman and McKee, 1971. 


\section{LA-4. GRANITE MOUNTAIN STOCK}

General location: Granite Mountain and vicinity, northern part of the Shoshone Range.

Coordinates: lat $40^{\circ} 22^{\prime} \mathrm{N}$, , long $116^{\circ} 45^{\prime} \mathrm{W}$.

Land classification: Private and public domain, with some patented mining claims.

Area: $11 \mathrm{~km}^{2}$.

Accessibility: Main outcrop is $10 \mathrm{~km}$ northwest of State Highway 21.

Remoteness: Main outcrop is $12 \mathrm{~km}$ north of Gold Acres.

Geologic setting: The pluton is composed predominantly of Tertiary granodiorite with some quartz monzonite and intrudes the following: Ordovician Valmy Formation composed of chert, quartzite, greenstone, and pillow lavas; Silurian to Devonian Roberts Mountains Formation, composed of 1 imestones; Devonian Slaven Chert; and the Triassic Panther Canyon Formation, composed of dolomite, limestone, interbedded shale, sandstone, and conglomerate. The pluton has been dated as $36.7 \pm 0.7 \mathrm{~m} . \mathrm{y}$. and $38.0 \pm 0.8 \mathrm{~m} . \mathrm{y}$. (Silberman and McKee, 1971). Much of the granodiorite is hydrothermally altered.

The major structure consists of a complex thrust-fault system known as the

Roberts Mountains Thrust. The thrust faulting displaces the Paleozoic rocks. High-angle normal faults are also present.

The granitic intrusives are within the Oregon-Nevada lineament.

Hydrologic setting: The pluton is in the Humboldt River Basin ground-water system and drainage basin--Crescent Valley tributary. The nearest discharge is $12 \mathrm{~km}$ east in Crescent valley, where water is used for livestock, irrigation, and domestic purposes.

Aeromagnetic expression: Although the northern mass of granitic rocks occurs in a low-amplitude magnetic depression, the main central mass is clearly associated with a moderately high-amplitude positive anomaly, and the southern mass is associated with a positive anomaly nose. The source is inferred to be predominantly plutonic rocks having a maximum areal extent of about $15 \mathrm{~km}^{2}$.

Mining activity: Gold and clay are being mined in the northern part of Shoshone Range (1976). Selected references: Silberman and McKee, 1971; Silberman, Wrucke, and Armbrustmacher, 1969. 
General location: $10 \mathrm{~km}$ south of the southern edge of the Fish Creek Mountains near Cain Creek.

Coordinates: lat $40^{\circ} 00^{\prime} \mathrm{N}$, long $117^{\circ} 12^{\prime} \mathrm{W}$.

Land classification: Public domain, with some private lands,

Area: $7 \mathrm{~km}^{2}$.

Accessibility: $5 \mathrm{~km}$ west of State Highway $8 \mathrm{~A}$.

Remoteness: $58 \mathrm{~km}$ northwest of Austin (population 300).

Geologic setting: The pluton is composed of Jurassic granodiorite and is in contact with Quaternary alluvium and Tertiary volcanic rocks that overlie the pluton unconformably. The intrusive contact is not exposed. The pluton has been dated as 155-3 m.y. (Silberman and McKee, 1971).

The structure consists of north-northeast-trending high-angle normal faults that displace the volcanic rocks and the pluton.

Hydrologic setting: The pluton is in the Humboldt River Basin ground-water system and Reese River and Antelope Valley tributary drainage basins. The nearest discharge is $7 \mathrm{~km}$ east into Reese River, where the water is used for irrigation, domestic, and livestock purposes.

Aeromagnetic expression: The granitic rocks occur on the northwestern flank of an elongate northwest-trending positive anomaly. Although a small part of the anomaly is associated with exposed basalts, the predominant subsurface source is inferred to be granitic rocks having a maximum areal extent of $15-25 \mathrm{~km}^{2}$.

Selected reference: Silberman and McKee, 1971. 


\section{LA-6. STEINER SPRING}

General location: Northern part of the Shoshone Mountains near Steiner Spring.

Coordinates: lat $39^{\circ} 48^{\prime} \mathrm{N}$., long $117^{\circ} 07^{\prime} \mathrm{W}$.

Land classification: Public domain.

Area: $1 \mathrm{~km}^{2}$ (cumulative).

Accessibility: $5 \mathrm{~km}$ west of State Highway $8 \mathrm{~A}$.

Remoteness: $36 \mathrm{~km}$ northwest of Austin (population 300).

Geologic setting: The pluton is composed of Jurassic to Tertiary granodiorite and quartz monzonite. The granitic rocks have not been dated. The pluton intrudes the Ordovician Valmy Formation, composed of chert, quartzite, greenstone, and pillow lavas. Tertiary rhyolitic volcanic rocks overlie the pluton unconformably.

A thrust fault is present $4 \mathrm{~km}$ southwest of the granitic intrusive. Northeast-trending high-angle normal faults are also present. A fault scarp in the alluvium is located $1 \mathrm{~km}$ southwest of the pluton.

Hydrologic setting: The pluton is in the Humboldt River Basin ground-water system and Reese River tributary drainage basin. The nearest discharge is $6 \mathrm{~km}$ east into Reese River, where water is used for irrigation, domestic, and livestock purposes.

Aeromagnetic expression: Although the small granitic rock outcrops occur on a broad magnetic plateau, no well-defined anomalies are associated with them.

Comment: A fault scarp is present in alluvium $1 \mathrm{~km}$ southwest of the pluton. 


\section{LA-7. IOWA CREEK STOCK}

General location: Northwest flank of the northern Toiyabe Range, near Iowa Creek.

Coordinates: lat $39^{\circ} 50^{\prime} \mathrm{N} .$, long $117^{\circ} 00^{\prime} \mathrm{W}$.

Land classification: Public domain.

Area: $1 \mathrm{~km}^{2}$.

Accessibility: $8 \mathrm{~km}$ east of State Highway $8 \mathrm{~A}$.

Remoteness: $37 \mathrm{~km}$ north of Austin (population 300).

Geologic setting: The pluton is composed of Cretaceous granite and quartz monzonite and intrudes the Ordovician Valmy Formation, which is composed of chert, quartzite, greenstone, and pillow lavas. Tertiary volcanic rocks are found in the vicinity of the pluton. The pluton has been dated as 67.9+2.7 m.y. (Silberman and McKee, 1971). A fault scarp in alluvium is located $4 \mathrm{~km}$ northeast of pluton.

Hydrologic setting: The pluton is in the Humboldt River Basin ground-water system and drainage basin--a tributary formed by Crescent and Carico Lake Valleys. The nearest discharge is $8 \mathrm{~km}$ west in Reese River, where water is used for irrigation, livestock, and domestic purposes.

Aeromagnetic expression: No single, well-defined anomaly is associated with the pluton. Comment: A fault scarp is present in alluvium $4 \mathrm{~km}$ northeast of pluton.

Selected reference: Silberman and McKee, 1971. 


\section{LA-8. RAVENSWOOD STOCK}

General location: Shoshone Mountains, near Gilberts Creek.

Coordinates: lat $39^{\circ} 42^{\prime} \mathrm{N}$, , long $117^{\circ} 12^{\prime} \mathrm{W}$.

Land classification: Public domain.

Area: $5 \mathrm{~km}^{2}$ (cumulative).

Accessibility: $8 \mathrm{~km}$ west of State Highway $8 \mathrm{~A}$.

Remoteness: $28 \mathrm{~km}$ northwest of Austin (population 300).

Geologic setting: The pluton is composed predominantly of cretaceous granite and quartz

monzonite, and intrudes quartzite and shales of Cambrian age.

Tertiary volcanic rocks overlie the pluton unconformably. The pluton

has been dated as $71.4 \pm 3$ m.y. (Silberman and McKee, 1971).

Northeast- and northwest-trending high-angle normal faults are the

predominant structures in the area. Fault scarps are present in the

alluvium, approximately $2 \mathrm{~km}$ northwest and $4 \mathrm{~km}$ east of the pluton.

Hydrologic setting: The pluton is in the Humboldt River Basin ground-water system and

Reese River and Antelope Valley tributary drainage basins. The

nearest discharge is $7 \mathrm{~km}$ east into Reese River, where the water

is used for irrigation, domestic, and livestock purposes.

Aeromagnetic expression: The granitic rocks occur on the flanks of a low-amplitude positive anomaly flexure of uncertain origin.

Comment: Fault scarp present in the alluvium, 2 and $4 \mathrm{~km}$ from the pluton.

Selected reference: Silberman and McKee, 1971. 


\section{LA-9. STEINER CREEK}

General location: Northwest flank of Simpson Park Mountains, $6 \mathrm{~km}$ northeast of Steiner Creek. Coordinates: lat $39^{\circ} 42^{\prime} \mathrm{N}$., long $116^{\circ} 47^{\prime} \mathrm{W}$.

Land classification: Private land.

Area: $1 \mathrm{~km}^{2}$.

Accessibility: State Highway 21 bisects exposure.

Remoteness: $34 \mathrm{~km}$ northeast of Austin (population 300).

Geologic setting: The pluton is composed of Cenozoic granite and intrudes the Silurian to Devonian Roberts Mountains Formation, which includes limestone and siltstone.

Northeast-trending high-angle faults are present in the area. A thrust fault is located $3 \mathrm{~km}$ south of the pluton.

Hydrologic setting: The pluton is in the Grass Valley ground-water system and drainage basin; both are hydrologically closed. Outcrops of the pluton are in discharge areas in the southern part of the valley. Water is used in the valley for irrigation, livestock, and domestic purposes. Aeromagnetic expression: The small plutonic rock exposure occurs on the relatively flat summit of a positive anomaly having an unknown source.

Selected reference: Silberman and McKee, 1971. 
LA-10. AUSTIN

General location: Central part of the Toiyabe Range, near Austin.

Coordinates: lat $39^{\circ} 28^{\prime} \mathrm{N}$., long $117^{\circ} 00^{\prime} \mathrm{W}$.

Land classification: Predominantly Toiyabe National Forest, with some private land and

Area: $161 \mathrm{~km}^{2}$ (cumulative).

patented mining claims.

Accessibility: U.S. Highway 50 bisects the main exposures.

Remoteness: Austin (population 300) is within the main pluton exposure.

Geologic setting: The pluton is composed of Jurassic quartz monzonite and granodiorite, with minor granitic rocks ranging from diorite to alaskite, and intrudes the following: Cambrian quartzite and shales; Ordovician Valmy Formation, composed of chert, quartzite, greenstone, pillow lavas, and shales; and the Devonian Slaven Chert. The pluton has been dated as $157 \pm 6$ m.y. (Krueger and Schi11ing, 1971).

The major structure of the area is a complex thrust-fault system known as the Roberts Mountains Thrust that displaces the Paleozoic rocks. Northeast- and northwest-trending high-angle normal faults are common. Fault scarps are present in the alluvium approximately $2 \mathrm{~km}$ east and southeast of the pluton.

Hydrologic setting: The pluton is in the Humboldt River Basin and Big Smoky Valley groundwater systems. Runoff drains to Reese River and Big Smoky Valleys. There is discharge near the center of the pluton and the water is used for livestock, public supply, and domestic purposes.

Aeromagnetic expression: Although a single positive anomaly is clearly associated with the northern mass of granitic rocks, the two large masses to the south have a complex magnetic signature. An elongate northwest-trending high-amplitude positive anomaly transects both of these masses as part of a magnetic lineament of unknown origin, that extends for a distance of at least $100 \mathrm{~km}$.

Comment: Fault scarps are present in the alluvium approximately $2 \mathrm{~km}$ from the pluton. Selected reference: Krueger and Schilling, 1971. 


\section{EUREKA COUNTY}

\section{GEOLOGY}

Eureka County (fig, 13) is located within the north-central part of the Basin and Range province, where most of the ranges trend in a north to northeast direction and are bounded by fault scarps on one or both sides. Movement along many of the faults has tilted the ranges eastward or southeastward. This tilting of the ranges is clearly shown by steep fault scarps along the western borders and the gradual merging with alluvium on the eastern flanks.

The most prominent feature of the geology in the county is the Roberts Mountains thrust, a major structural element of the Antler orogenic belt. This thrust brings into contact thick sections of rock of early and middle Paleozoic age which contrast greatly in lithology. The upper plate of the thrust is almost entirely siliceous, consisting of sandstone, quartzite, shale, greenstone, and chert, whereas, the lower eastern assemblage is made up of a sequence of rocks composed almost entirely of carbonates. After the major thrusting event, coarse clastics, eroded from highlands to the west, were deposited over the older facies. This overlap assemblage was subsequently folded and thrust faulted by intermittent orogenic movements during late Paleozoic and Mesozoic time.

During the Mesozoic and extending into Tertiary time, many of the granitic rock masses were emplaced along structural zones of weakness associated with past deformation. The intrusives are chiefly composed of quartz monzonite and granodiorite, although several exposures are composed of alaskite. Mineralized areas, commonly associated with the intrusives, are mainly silver-gold-lead-zinc replacement deposits in eastern assemblage host rocks.

The Oregon-Nevada lineament (pl. 4), trending in a north-northwest direction, extends into the southwestern part of the county. The lineament is marked by closely spaced faults, centers of volcanic activity, and a conspicuous aeromagnetic anomaly (Stewart and others, 1975). The lineament may represent the surface expression of a deep-seated fracture zone and may be related to a system of interrelated strike-slip and tension zones.

Much of the information summarized for Eureka County has been abstracted from: Roberts, Montgomery, and Lehner, 1967.

\section{HYDROLOGY}

The Monitor Valley drainage basin coriverges with drainage from Kobeh and Antelope Valleys and virtually terminates at Devils Gate. Only rarely does water flow through Devils Gate into Diamond Valley, a closed drainage basin. During the last Pleistocene pluvial period, the Diamond Valley lake spilled through Railroad Pass (northern end of the Diamond Mountains; south of Elko County line) into Huntington Valley. Grass Valley, which lies mostly west of Eureka County in Lander County, is also a closed drainage basin. The northern half of the county is drained by tributaries to the Humboldt River, such as Pine, Maggie, and Boulder Creeks.

Sources of runoff and recharge above an altitude of 1,981 $\mathrm{m}$ in Eureka County are:

Monitor Range (north end)

Antelope Range

Fish Creek Range (north end)

Diamond Mountains
Sulphur Spring-Pinion Ranges

Cortez and Tuscarora Mountains

Simpson Park Mountains 


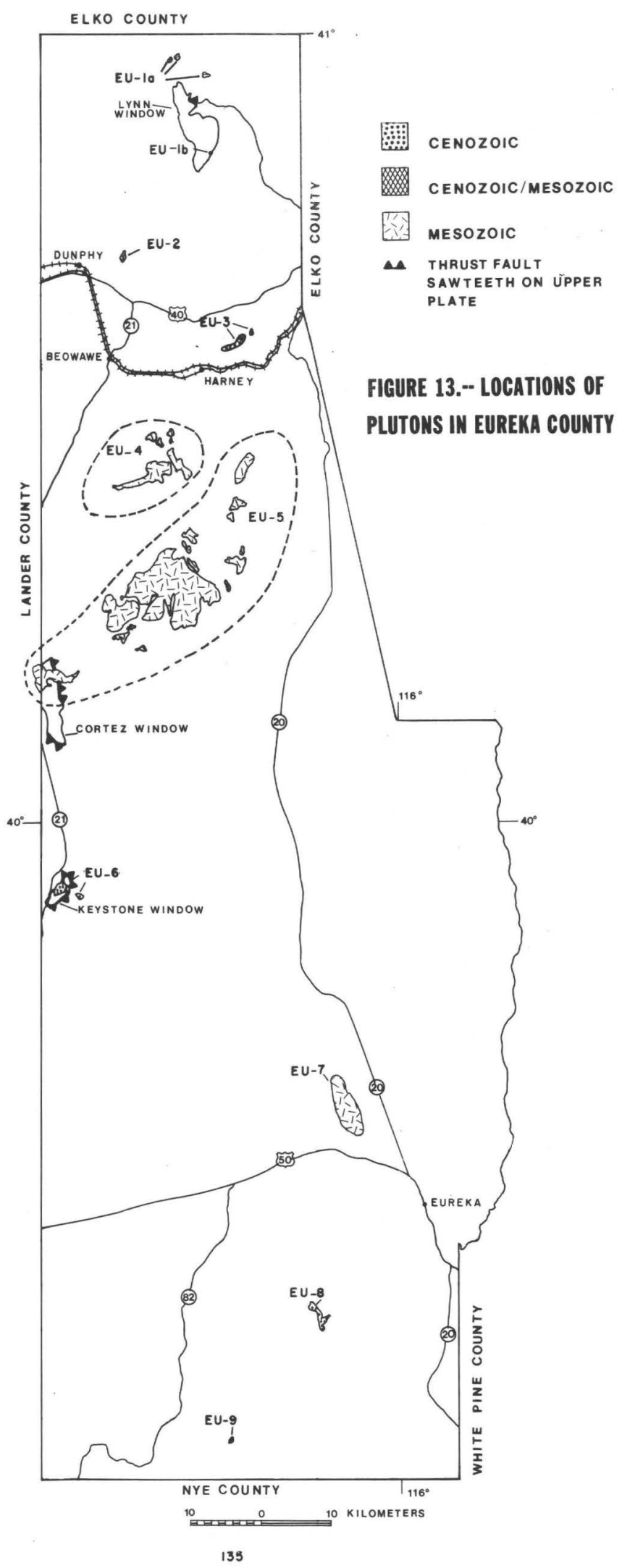


The Monitor Valley ground-water system of northerly movement terminates in the Bean Flat area, and the system includes Antelope and Kobeh Valleys, Diamond and Grass Valleys are hydrologically closed individual systems. A part of the Humboldt River Basin groundwater system, featuring subsurface movement approximately in accord with surface-water drainage underlies the northern half of the county.

The hydrology of Eureka County was taken mainly from the following references: Eakin, 1961a, 1962c; Eakin and Lamke, 1966; Rush and Everett, 1964. 


\section{EU- $1 \mathrm{a}$ and 1b. TUSCARORA MOUNTAINS}

Plutons exposed in the Tuscarora Mountains have been divided into two segments. Part (1a) incorporates those bodies located near the northern county line and part (1b) describes a pluton located near the central part of the range, along the eastern edge of the Lynn Window.

(1a) General location: North-central part of county, north of the Lynn mining district. Coordinates: lat $40^{\circ} 57^{\prime} \mathrm{N}$, , long $116^{\circ} 21^{\prime} \mathrm{W}$. Land classification: Private lands (railroad). Area: $4 \mathrm{~km}^{2}$.

Accessibility: U.S. Highway 40 is $33 \mathrm{~km}$ south of the outcrops. Western Pacific and Southern Pacific Railroads pass $40 \mathrm{~km}$ south of the area. A hard-surface secondary road extends northwest from Carlin to the Carlin Mine, approximately $4 \mathrm{~km}$ south of the outcrops.

Remoteness: The town of Carlin (population 1,313) in Elko County is $33 \mathrm{~km}$ to the southeast. Geologic setting: Intrusive bodies exposed within the area are composed of granodiorites, granite, and diorite. The intrusives intrude the Ordovician Vinini Formation, which is mainly composed of black to brown interbedded chert and shale. The Vinini Formation is part of the upper plate of the Roberts Mountains thrust.

Hydrologic setting: The mountains are in the Humboldt River Basin ground-water system. Runoff drains to Maggie Creek, a tributary of the Humboldt. The nearest discharge area is $13 \mathrm{~km}$ east in Maggie Creek, and the water is used for livestock and domestic purposes.

Aeromagnetic expression: The granitic rocks are variously associated with positive and negative anomalies.

Mining activity: One gold and silver mine is active in the immediate vicinity of northwestern exposure, and three gold mines are in operation within the Lynn mining district, south and southwest of the exposures.

(1b) General location: Northwest of Marys Mountain. Coordinates: lat $40^{\circ} 51^{\prime} \mathrm{N}$, , long $116^{\circ} 18^{\prime} \mathrm{W}$. Land classification: Private lands (railroad). Area: Less than $1 \mathrm{~km}^{2}$. Accessibility: U.S. Highway 40 and Western Pacific (Southern Pacific) Railroad pass $23 \mathrm{~km}$ and $30 \mathrm{~km}$ south of the area, respectively. The Carlin Mine seconciary road is $6 \mathrm{~km}$ east of the outcrop.

Remoteness: The exposure is $22 \mathrm{~km}$ northwest of Carlin (population 1,313) in Elko County. Geologic setting: A small circular granitic stock of Cretaceous(?) age intrudes the Cambrian Hamburg Dolomite and the Ordovician Eureka Quartzite. At this locality the Hamburg has been thrust over the younger Eureka. The intrusion may be related to this zone of weakness along the thrust fault. 


\section{EU-1b. TUSCARORA MOUNTAINS--Continued}

Hydrologic setting: The area is in the Humboldt River Basin ground-water system and runoff drains to Maggie Creek. The nearest discharge is $6 \mathrm{~km}$ east, and the water is used for livestock and domestic purposes.

Mining activity: The exposure is located near the Lynn mining district, where several gold and silver mines are in operation. 


\section{EU-2. BOULDER VALLEY}

General location: Northeast of the Shoshone Range in the northern part of the county. Coordinates: lat $40^{\circ} 43^{\prime} \mathrm{N}$, , long $116^{\circ} 27^{\prime} \mathrm{W}$.

Land classification: Private lands.

Area: $3 \mathrm{~km}^{2}$.

Accessibility: U.S. Highway 40 is about $4 \mathrm{~km}$ south of the exposure. Western Pacific and Southern Pacific Railroads lie $5 \mathrm{~km}$ south of the area.

Remoteness: The town of Carlin (population 1,313) is $28 \mathrm{~km}$ to the east. The town of Battle Mountain (Lander County, population 1,856) is $41 \mathrm{~km}$ west of the outcrop. The exposure also is $6 \mathrm{~km}$ east of the small town of Dunphy.

Geologic setting: The intrusive of Mesozoic or Tertiary age intrudes interbedded shales, cherts, and quartzites tentatively assigned to the Vinini Formation (Ordovician). The western margin of the pluton is covered by alluvium underlying Boulder Valley.

Hydrologic setting: The pluton is in the Humboldt River Basin ground-water system and drainage basin. The nearest discharge occurs $1 \mathrm{~km}$ west, and water is used in this area for irrigation, livestock, and domestic purposes.

Aeromagnetic expression: The granitic rock outcrop is on the western flank of a regional north-trending positive anomaly having an unknown source.

Comment: The Humboldt River passes about $5 \mathrm{~km}$ southwest of the outcrop. 
EU-3. BUCK RAKE

General location: Southern end of the Tuscarora Mountains, north of the Humboldt River at Buck Rake Creek.

Coordinates: lat $40^{\circ} 37^{\prime} \mathrm{N}$. , long $116^{\circ} 16^{\prime} \mathrm{W}$.

Land classification: Private lands (railroad).

Area: $5 \mathrm{~km}^{2}$.

Accessibility: U.S. Highway 40 is $5 \mathrm{~km}$ north of the main exposure. Western Pacific and Southern Pacific Railroads pass about $1.5 \mathrm{~km}$ south of the area.

Remoteness: The dominant outcrop 1 ies $16 \mathrm{~km}$ southwest of Carlin (Elko County, population 1,313 ) and $47 \mathrm{~km}$ southwest of Elko (Elko County, population 7,621).

Geologic setting: The pluton is predominantly made up of quartz monzonite that intrudes a sequence of volcanic rocks presumably of Jurassic or Cretaceous age. This sequence is composed chiefly of three informal members: (1) a lower member of medium-grained, thin-bedded, volcanic sandstone, (2) a middle member of ash-flow tuff, and (3) an upper member of rhyolite and rhyodacite flows.

The northwestern margin of the main outcrop is covered by a sequence of Tertiary volcanic rocks composed of interlayered andesite, rhyolite, and tuff.

Hydrologic setting: The pluton is in the Humboldt River Basin ground-water system and drainage basin. The nearest discharge occurs $3 \mathrm{~km}$ south, and water is used in the area for livestock, domestic, and irrigation purposes.

Aeromagnetic expression: The granitic rocks occur on the southern flank of a short-wavelength high-amplitude positive anomaly having an unknown source.

Mining activity: An open-pit iron mine is active at the mouth of Safford Canyon, south of the main granitic body and east of Harney. 


\section{EU-4. DRY HILLS}

General location: Southern Dry Hills, south of the Humboldt River.

Coordinates: lat $40^{\circ} 27^{\prime} \mathrm{N}$., long $116^{\circ} 24^{\prime} \mathrm{W}$. (central location).

Land classification: Public and private lands.

Area: $22 \mathrm{~km}^{2}$ (cumulative).

Accessibility: State Highway 21 extends southward from U.S. Highway 40 and passes $8.5 \mathrm{~km}$ west of the western exposures.

Remoteness: Northernmost exposures are $32 \mathrm{~km}$ southwest of Carlin (Elko County, population

1,313). The western exposures are $46 \mathrm{~km}$ southeast of Battle Mountain (Lander County, population 1,856).

Geologic setting: Intrusives exposed in the Dry Hills are predominantly composed of granodiorite and fine-grained monzodiorite believed to be related to the Early Cretaceous(?) intrusives in the Cortez Mountains. The principal pluton cuts fine-grained sandstones of the Brock Canyon(?) Formation that may be Pennsylvanian or Permian in age. At several places along the western margin, the pluton intrudes quartz latite porphyry of Permian(?) age. Along the southwestern boundary, the main pluton is in fault contact with undivided volcanic rocks of Tertiary or Quaternary age.

The northwestern flank of the Dry Hills is marked by a series of northeasttrending normal faults, which extends into the alluvium.

Hydrologic setting: The pluton is in the Humboldt River Basin ground-water system. Runoff drains to Crescent Valley and the nearest discharge is $8 \mathrm{~km}$ west, in the valley; nearby springs may intercept some of the ground-water flow. Water is used in the area for irrigation, livestock, and domestic purposes.

Aeromagnetic expression: The exposures of granitic rocks occur in a regional low-amplitude magnetic depression.

Selected reference: Muffler, 1964. 
General location: Prominant northeast-trending range south of the Humboldt River. Coordinates: lat $40^{\circ} 19^{\prime} \mathrm{N}$. , long $116^{\circ} 22^{\prime} \mathrm{W}$. (central location).

Land classification: Public and private lands.

Area: $138 \mathrm{~km}^{2}$ (cumulative).

Accessibility: The westernmost exposure, near Mount Tenabo, is about $13 \mathrm{~km}$ southeast of

State Highway 21. Light-duty improved State road 21 cuts through Cortez Canyon south of the exposures.

Remoteness: Outcrops in the northern part of the range are about $31 \mathrm{~km}$ southwest of Carlin

(Elko County, population 1,313), and the central exposure is $57 \mathrm{~km}$ southeast of Battle Mountain (Lander County, population 1,856).

Geologic setting: Granitic rocks making up the central mass in the Cortez Mountains dominantly consist of granodiorite and quartz monzonite and subordinate amounts of diorite, tonalite, alaskite, and quartz albitite. Almost every type of granitic rock has undergone deuteric alteration. Several radiometric age determinations of samples ranging from diorite to quartz monzonite indicate ages ranging from 125 to $150 \mathrm{~m} . \mathrm{y}$. (Schilling, 1965). Interlaced with these plutons are dikes and irregular bodies of altered dacite and rhyodacite porphyry. These plutons mainly intrude conglomerate, limestone, and dolomite that have been assigned to the Brock Canyon Formation of Pennsylvanian or Permian age. The contacts commonly are sharp or form a narrow zone of shearing parallel to the bedding in the host rock.

The northern intrusive outcrops are composed of alaskite and cut a Jurassic or Cretaceous sequence of volcanic rocks, composed mainly of rhyolite and ash-flow tuff.

The westernmost outcrop (Mill Canyon stock) located along the county line mainly intrudes the eastern assemblage carbonate rocks that are exposed in the cortez window. The stock is a composite intrusive consisting of quartz monzonite, with a granodiorite border zone in the eastern part. A sample of quartz monzonite has been dated as 150 m.y. (Wells, J.D., and others, 1971).

The northwestern edge of Cortez Mountains is marked by the Crescent Fault scarp.

Hydrologic setting: The mountains are in the Humboldt River Basin ground-water system. Runoff drains to the Pine Creek and Crescent Valley tributaries to the Humboldt River. The nearest discharge point is $15 \mathrm{~km}$ to the southeast, but springs at the eastern mountain front may intercept part of the ground-water flow. Water is used in Pine Valley for livestock, irrigation, and domestic purposes. 
EU-5. CORTEZ MOUNTAINS--Continued

Aeromagnetic expression: Most of the granitic rocks occur in areas of negative anomalies having low-magnetic relief. One mass is on the northern flank of a high-amplitude positive anomaly principally associated with basalt.

Mining activity: A gold and silver mine is in operation (1976) approximately 8 km southwest of the main body in the Buckhorn mining district.

Comment: The westernmost exposure (Mi11 Canyon stock) is within the Oregon-Nevada 1 ineament. Selected references: Gilluly and Masursky, 1965; Muffler, 1964; Schilling, 1965; Stewart, McKee, and Stager, 1977; Stewart, Walker, Kleinhampl, 1975; We11s, Elliot, and Obradovich, 1971. 


\section{EU-6. WALTI}

General location: Simpson Park Mountains near the western county line.

Coordinates: lat $39^{\circ} 55^{\prime} \mathrm{N}$., long $116^{\circ} 34^{\prime} \mathrm{W}$. (main mass).

Land classification: Public domain.

Area: $5 \mathrm{~km}^{2}$ (cumulative).

Accessibility: Light-duty improved State road 21 intersects State Highway 21 and passes within $1 \mathrm{~km}$ of the western exposures.

Remoteness: The dominant exposure 1 ies $86 \mathrm{~km}$ southeast of Battle Mountain (Lander County, population 1,856) and $65 \mathrm{~km}$ northwest of Eureka (population 500).

Geologic setting: The main stock consists largely of porphyritic granodiorite approximately 33 m.y. old (Silberman and McKee, 1971). The dominant exposure occurs in the Keystone window, exposing eastern assemblage carbonate rocks of Devonian age. The smaller exposure generally cuts chert, shale, and quartzite, representing remnants of the Roberts Mountains upper thrust plate that is believed to be equivalent to the Vinini Formation (Ordovician).

A fault scarp marks the western edge of the range north and south of the pluton.

Hydrologic setting: The pluton is in the Grass Valley ground-water system and drainage basin--hydrologically closed. The nearest discharge point is $4 \mathrm{~km}$ west, and water is used in the valley for livestock, irrigation, and domestic purposes.

Aeromagnetic expression: The main exposure of granitic rock occurs on the steep northern flank of an equidimensional high-amplitude positive anomaly. Subsurface equivalents of these rocks are inferred to be the anomaly source. The maximum areal extent of the anomaly source is estimated to be $15 \mathrm{~km}^{2}$.

Comment: The eastern exposure lies within the Oregon-Nevada lineament.

Selected references: Silberman and McKee, 1971; Stewart, Walker, and Kleinhampl, 1975. 
General location: Northwest of Eureka.

Coordinates: lat $39^{\circ} 38^{\prime} \mathrm{N}$., long $116^{\circ} 06^{\prime} \mathrm{W}$.

Land classification: Public domain.

Area: $23 \mathrm{~km}^{2}$.

Accessibility: State Highway 20 passes $3 \mathrm{~km}$ east,

Remoteness: Eureka (population 500) is located $13 \mathrm{~km}$ to the southeast.

Geologic setting: The pluton underlying most of Whistler Mountain is composed of muscovite alaskite (resembles aplite in hand specimen) and has intruded shales of the Ordovician Vinini Formation as well as Paleozoic carbonate formations. Intense isoclinal folds in the Vinini occur along the western edge of the pluton. A sample of the intrusive described as quartz monzonite, was radiometrically dated at $165(+25,-8)$ m.y.

Hydrologic setting: The pluton is in the Diamond and Monitor Valleys ground-water systems, and runoff drains to Diamond and Kobeh Valleys. The nearest discharge is $6 \mathrm{~km}$ southwest, and water is used in Kobeh Valley for irrigation, livestock, and domestic purposes.

Aeromagnetic expression: No single distinct anomaly is associated with the pluton, presumably because of its silicic composition.

Selected references: Merriam and Anderson, 1942; Schilling, 1965. 
EU-8. WOOD CONE PEAK

General location: Southern Mahogany Hills,

Coordinates: lat $39^{\circ} 29^{\prime} \mathrm{N}$., long $116^{\circ} 06^{\prime} \mathrm{W}$.

Land classification: Public domain.

Area: $3 \mathrm{~km}^{2}$.

Accessibility: U.S. Highway 50 passes $20 \mathrm{~km}$ north of the outcrop.

Remoteness: The exposure is located approximately $21 \mathrm{~km}$ southwest of Eureka.

Geologic setting: The intrusive is composed of granodiorite porphyry that has intruded shaly carbonate, possibly of the Ordovician Pogonip Group and the Ordovician Eureka Quartzite. The northwestern margin of the outcrop is covered by the alluvium underlying Antelope Valley.

Hydrologic setting: The pluton is in the Monitor Valley ground-water system and Antelope Valley drainage basin. The nearest discharge point is $12 \mathrm{~km}$ west and the water is used for livestock and domestic purposes.

Aeromagnetic expression: The granitic rocks occur on the steep northern flank of a northtrending elliptical short-wavelength positive anomaly inferred to have a source of similar rocks. The maximum areal extent of the buried source is estimated to be $10 \mathrm{~km}^{2}$. 


\section{EU-9. NINEMILE CANYON}

General location: Northern Antelope Range.

Coordinates: lat $39^{\circ} 13^{\prime} \mathrm{N}$, long $116^{\circ} 17^{\prime} \mathrm{W}$.

Land classification: Public domain.

Area: $1 \mathrm{~km}^{2}$.

Accessibility: The outcrop is located $35 \mathrm{~km}$ south of U,S. Highway 50 .

Remoteness: Approximately $43 \mathrm{~km}$ southwest of Eureka.

Geologic setting: A small circular stock occurs along the western flank of the range directly south of Ninemile Canyon. The stock intrudes carbonate rocks assigned to the Ordovician Pogonip Group. Southeast of the outcrop these rocks are overlain by andesitic flows and pyroclastic rocks.

Hydrologic setting: The pluton is in the Monitor Valley ground-water system and Antelope Valley drainage basin. The nearest significant discharge point is $22 \mathrm{~km}$ north; however, a ranch well $7 \mathrm{~km}$ north probably intercepts some of the ground-water flow. Water is used in Antelope Valley for livestock and domestic purposes.

Aeromagnetic expression: No well-defined anomaly is associated with the pluton. 
White Pine County (fig. 14) is located in east-central Nevada and consists of elongated north-trending mountain ranges separated by wide basins.

The county is underlain by rocks of sedimentary, igneous, and metamorphic origin, from Precambrian to Pliocene in age. The Precambrian to Lower Triassic sedimentary rocks make up the Cordilleran miogeosyncline. Middle or Upper Triassic or Jurassic sedimentary rocks have not been identified in the county. Cretaceous rocks occur in the westernmost part of the county (Hose and others, 1976).

Tertiary deposits consist of sedimentary and volcanic types. The volcanic rocks include ash-flow tuffs, lavas having compositions that range from rhyolite through andesite.

Plutonic rocks are of Jurassic, Cretaceous, and Tertiary age and range in composition from granite through quartz monzonite to granodiorite (Hose and others, 1976).

The area was not exposed to any major tectonism during the Paleozoic Era. Two major tectonic events took place in the county. The first event took place during late Mesozoic to early Tertiary and consists of high-angle normal faults, thrust faults, and folds; the second tectonic event took place during the Tertiary and Quaternary Periods reaching its climax in late Miocene (Hose and others, 1976). The second tectonic event consists of high-angle faults, resulting in elongated fault-block mountain ranges and basins that form the present topography.

Geologic data were extracted and summarized from the following: Hose, Blake, and Smith, 1976.

\section{HYDROLOGY}

The White River drainage basin heads in south-central White Pine County and runoff moves southward. Huntington Valley heads in northwest White Pine County and surface flow moves northward, tributary to the Humboldt River. The remaining valleys entirely within the county drain centripetally into lakes and playas. Along the Utah State line, Snake, Deep Creek, Pleasant, and Hamlin Valleys drain eastward into Utah, thence northward into the Great Salt Lake Desert.

Major sources of runoff and recharge are Snake, Schell Creek, and Egan Ranges, also. Diamond Mountains and the southern Ruby Mountains. Minor sources of recharge include Pancake, White Pine, and Antelope Ranges and Butte Mountains.

The White River ground-water system of southerly subsurface flow includes Long and Jakes Valleys. The Railroad Valley ground-water system heads in the southwestern part of the county. The Newark Valley ground-water system receives underflow from Fish Creek Valley, and no outflow from Newark Valley is known to occur. The southern Butte Valley ground-water system has no known subsurface outflow, but carbonate rocks may leak water to adjacent valleys. The Steptoe Valley ground-water system features northward movement into northern Steptoe Valley in Elko County. Water of the Spring Valley ground-water system moves southward, and near the south end of the valley flows outward to Hamlin Valley on the east. 


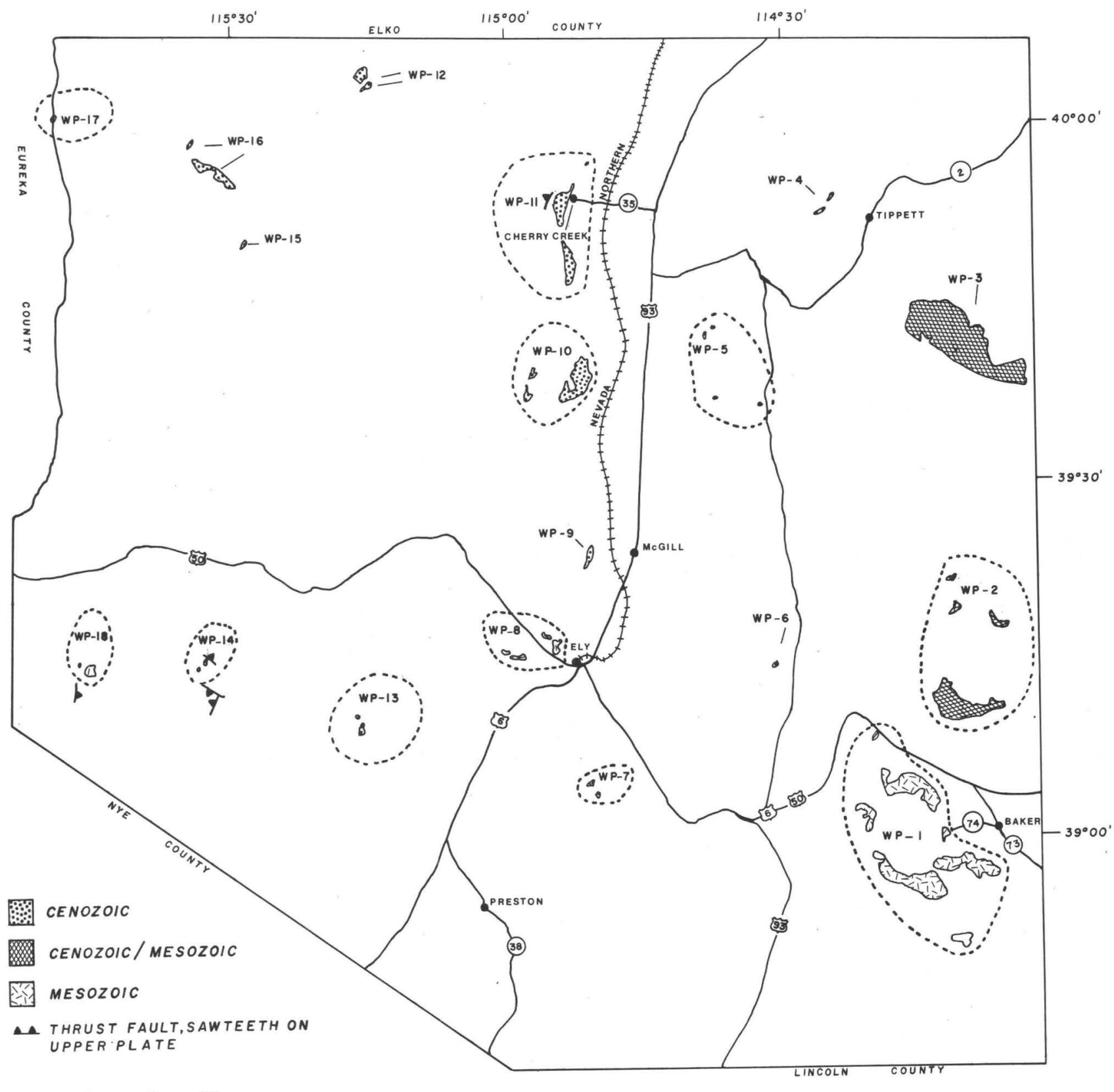

- $10 \quad 20 \quad 30$ KILOMETERS

FIGURE 14.-- LOCATIONS OF PLUTONS IN WHITE PINE COUNTY 
Hamlin Valley is part of the Snake Valley ground-water system, largely in Utah, and aquifers along the Utah State line feed water eastward into this system.

The hydrology of White Pine County was taken primarily from the following references: Eakin, 1960, 1961b, 1966; Eakin, Hughes, and Moore, 1967; Glancy, 1968a, 1968b; Hood and Rush, 1965; Rush and Kazmi, 1965. 
WP-1. SOUTHERN SNAKE RANGE

General location: Northern end of the southern Snake Range.

Coordinates: lat $38^{\circ} 58^{\prime}$ N., long $114^{\circ} 13^{\prime} \mathrm{W}$.

Land classification: Humboldt National Forest.

Area: $84 \mathrm{~km}^{2}$ (cumulative).

Accessibility: Northernmost major exposure is $3 \mathrm{~km}$ south of U.S. Highway 50 and 6 .

Remoteness: $8 \mathrm{~km}$ west of Baker (population 20) and $52 \mathrm{~km}$ southeast of Ely (population $6,216)$.

Geologic setting: The pluton is composed of Jurassic quartz monzonite and granodiorite, and intrudes the following: Precambrian McCoy Creek Group (Misch and Hazzard, 1962), composed of quartzite, schists, and pelitic rocks and the Stella Lake Quartzite; Precambrian and Cambrian Prospect Mountain Quartzite, Cambrian Pioche Shale, and other limestones and shales of Cambrian age. The pluton has been dated with more than 50 radiometric age dates ranging from 17 to 240 m.y. Lee, Marvin, Stern, and Peterman (1970) attributed the younger ages to renewed movement along the Snake River dêcollement. Most consistent dates range from 156 to 160 m.y.

The major structure of the area is a complex thrust fault system of Mesozoic age known as the Snake River dêcollement (Hose and others, 1976). The intrusive bodies of the area cut the lower plate of the thrust but not the upper plate. Other structures include high-ang?e normal faults of Mesozoic and Cenozoic age.

Hydrologic setting: The pluton is in Snake Valley and Spring Valley ground-water systems. Runoff drains to Hamlin and Spring Valleys drainage basins. Discharge occurs at Lehman Caves National Monument

Mining activity: Gold placer mining activity in northwestern part of range, and tungsten mining in southeastern part of range.

Aeromagnetic expression: Most of the granitic rock exposures occur on the western flank of a regional positive anomaly having an unknown source. The maximum areal extent of that part of the buried source within Nevada is estimated to be $200 \mathrm{~km}^{2}$. The source may have a variable lithologic nature.

Comment: Pluton is near mining activity and complex thrust fault system. Selected references: Hose, Blake, and Smith, 1976; and Lee, Marvin, Stern, and Peterman, 1970; Misch and Hazzard, 1962. 
General location: Southern end of the northern Snake Range.

Coordinates: lat $39^{\circ} 15 \mathrm{~N}$., long $114^{\circ} 12^{\prime} \mathrm{W}$. (southernmost and major exposure).

Land classification: Humboldt National Forest.

Area: $39 \mathrm{~km}^{2}$ (cumulative).

Accessibility: $9 \mathrm{~km}$ north of U.S. Highway 50 and 6 .

Remoteness: $14 \mathrm{~km}$ northwest of Baker (population 20), $55 \mathrm{~km}$ east of Ely (population 6,216),

and $50 \mathrm{~km}$ southeast of McGill (population 2,164).

Geologic setting: The pluton is composed of Cretaceous-Tertiary quartz monzonite and granodiorite, and intrudes shaie, limestone, and quartzite of Cambrian age. Other sedimentary rocks intruded by the pluton include the following: Ordovician Pogonip Group, composed of limestone and quartzite, and the Eureka Quartzite; Devonian Guilmette Formation, composed of 1 imestone, and Sevy and Simonson Dolomites; Devonian and Mississippian Pilot Shale and Mississippian Chainman Shale and Joana Limestone. Parts of the pluton have been metamorphosed to gneiss. The micas from the gneiss have been dated at $25.5 \pm 1.3$ and $31 \pm 1.7 \mathrm{~m} . y$. (Lee and others, 1970).

The major structure is a complex thrust fault system of Mesozoic age known as the Snake River dêcollement. The granitic bodies intrude the lower plate of the thrust but not the upper plate. Northeast- and northwesttrending high-angle normal faults are also present, offsetting the thrust plates.

Hydrologic setting: The pluton is in the Snake and Spring Valleys ground-water systems and drainage basins. The nearest discharge is $12 \mathrm{~km}$ east in the Snake Valley, Utah, where water is used primarily for livestock, domestic, and irrigation purposes.

Aeromagnetic expression: No distinct regional anomaly is associated with the pluton.

Comment: Pluton is near complex thrust fault system.

Selected reference: Lee, Marvin, Stern, and Peterman, 1970. 


\section{WP-3. KERN MOUNTAINS}

General location: Kern Mountains near Utah State line.

Coordinates: lat $39^{\circ} 42^{\prime} \mathrm{N}$., long $114^{\circ} 12^{\prime} \mathrm{W}$.

Land classification: Predominantly public domain, with some private lands and patented mining claims.

Area: $107 \mathrm{~km}^{2}$ (cumulative).

Accessibility: $10 \mathrm{~km}$ southeast of State Highway 2.

Remoteness: $15 \mathrm{~km}$ southeast of Tippett and $50 \mathrm{~km}$ northeast of McGill (population 2,164).

Geologic setting: The pluton is composed mainly of granodiorite, with some quartz monzonite and granite, and intrudes Ordovician-Silurian sedimentary rocks, Simonson and Sevy Dolomites of Devonian age, Pilot Shale of Devonian and Mississippian age, Joana Limestone and Chainman Shale of Mississippian age, and Ely Limestone and Riepe Spring Limestone of Steele (1960) of Pennsylvanian and Permian age. The pluton is of Cretaceous-Tertiary age, and has been dated as $23.3 \pm 0.6,48.2 \pm 1.0$, and $72 \pm 7 \mathrm{m.y}$. (Hose and others, 1976).

A complex thrust fault system is the prominent structure feature of the area. Other minor structures include the younger northwest-trending high-angle normal faults.

Hydrologic setting: The pluton is in the Snake and Spring Valleys ground-water systems.

Runoff drains to the Snake, Antelope, and. Spring Valleys basins. The nearest discharge is $30 \mathrm{~km}$ eastward in Snake Valley (in Utah), where water is used mainly for livestock, domestic, and irrigation purposes.

Aeromagnetic expression: The main granitic rock mass occurs in a regional west-trending magnetic depression, which is presumably the polarization low connected with a regional west-trending high-amplitude magnetic ridge immediately to the south. The source of the positive anomaly is unknown.

Selected references: Hose, Blake, and Smith, 1976; Steele, 1960. 
WP-4. ANTELOPE RANGE

General location: Central part of the Antelope Range.

Coordinates: lat $39^{\circ} 53^{\prime}$ N., long $114^{\circ} 27^{\prime} \mathrm{W}$.

Land classification: Public domain.

Area: $2 \mathrm{~km}^{2}$ (cumulative).

Accessibility: $7 \mathrm{~km}$ northwest of State Highway 2.

Remoteness: $7 \mathrm{~km}$ west of Tippett and $60 \mathrm{~km}$ northeast of McGill (population 2,164).

Geologic setting: The pluton is composed of Tertiary quartz monzonite and intrudes the upper part of the Ordovician-Silurian sedimentary rocks; Devonian Simonson and Sevy Dolomites; and Permian Rib Hill Sandstone and Arcturus Formation, composed of limestone, sandstone, and siltstone. The structure of the area consists of normal and thrust faults.

Hydrologic setting: The pluton is in the Spring Valley ground-water system and the Antelope and Spring Valleys drainage basins. The nearest significant discharge is $43 \mathrm{~km}$ south in Spring Valley, where the water is used primarily for livestock and domestic purposes and a small amount for irrigation.

Aeromagnetic expression: The granitic rock outcrops occur in a magnetic depression presumably unrelated to the rocks.

Comment: Area is near complex thrust fault system. 
General location: Northern Schell Creek Range.

Coordinates: lat $39^{\circ} 37^{\prime} \mathrm{N}$., long $114^{\circ} 37^{\prime} \mathrm{W}$.

Land classification: Humboldt National Forest and some private land.

Area: $2 \mathrm{~km}^{2}$ (cumulative).

Accessibility: $8 \mathrm{~km}$ east of U.S. Highway 93 and $11 \mathrm{~km}$ east of Nevada Northern Railroad.

Easternmost outcrop is located $2 \mathrm{~km}$ west of a paved road.

Remoteness: $26 \mathrm{~km}$ north-northeast of McGi1l (population 2,164).

Geologic setting: The pluton is composed of Tertiary quartz monzonite and intrudes the Ordovician Pogonip Group, composed of limestone and quartzite, and the Eureka Quartzite; Devonian-Mississippian Pilot Shale, Mississippian Joana Limestone and Chainman Shale; Pennsylvanian Ely and Riepe Spring Limestones; and the Permian Park City Group, made up of 1 imestone and dolomites.

The area consists of a complex thrust fault system, with north-northeasttrending high-angle normal faults.

Hydrologic setting: The pluton is in the Spring Valley ground-water system and drainage basin. The nearest discharge occurs $20 \mathrm{~km}$ southeast where the water is used for livestock, domestic, and some irrigation purposes. Aeromagnetic expression: The small granitic rock outcrops occur in various places beneath both positive and negative anomalies. 
WP-6. INDIAN CREEK

General location: East flank of the central Schell Creek Range, near Indian Creek.

Coordinates: lat $39^{\circ} 16^{\prime} \mathrm{N} .$, long $114^{\circ} 31^{\prime} \mathrm{H}$.

Land classification: Humboldt National Forest.

Area: Less than $1 \mathrm{~km}^{2}$.

Accessibility: $23 \mathrm{~km}$ north of U.S. Highway 50 and 6 and $1 \mathrm{~km}$ west of a paved road.

Remoteness: $30 \mathrm{~km}$ east of Ely (population 6,216).

Geologic setting: The pluton is composed of Tertiary quartz monzonite and intrudes the Precambrian McCoy Creek Group of Misch and Hazzard (1962), made up of quartzite, schists, and pelitic rocks. The structure of the area consists of normal and thrust faults that disrupt the Precambrian rocks.

Hydrologic setting: The pluton is in the Spring Valley ground-water system and drainage basin. The nearest discharge occurs $5 \mathrm{~km}$ east in Spring Valley, where the water is used for livestock and domestic purposes, and a small amount for irrigation.

Aeromagnetic expression: A regional west-trending low-amplitude positive anomaly is centered over the outcrop. It is likely that this anomaly is underlain by similar granitic rocks. The maximum areal extent of the inferred source is $100 \mathrm{~km}^{2}$.

Selected reference: Misch and Hazzard, 1962. 
General location: East flank of the southern part of the Egan Range, near Ward Gulch. Coordinates: lat $39^{\circ} 05^{\prime} \mathrm{N}$., long $114^{\circ} 52^{\prime} \mathrm{W}$.

Land classification: Public domain, with some private land.

Area: $2 \mathrm{~km}^{2}$ (cumulative).

Accessibility: $9 \mathrm{~km}$ southwest of U.S. Highway 50 and 6 .

Remoteness: $33 \mathrm{~km}$ south of Ely (population 6,216).

Geologic setting: The pluton is composed of Tertiary quartz monzonite, and intrudes the Pennsylvanian Ely and Riepe Spring Limestones, and the Permian Arcturus Formation, composed of limestone, sandstone, and siltstone. McKee and Marvin (1976) report the age of the pluton as $35.1 \pm 1.3$ m.y. The structure of the area consists of normal faults.

Hydrologic setting: The pluton is in the Steptoe Valley ground-water system and drainage basin. Major discharge occurs $45 \mathrm{~km}$ north, but some ground-water flow may be intercepted $10 \mathrm{~km}$ northeast in upper Steptoe Creek. Water is used in the valley mainly for livestock, domestic, and irrigation purposes.

Aeromagnetic expression: The small granitic rock outcrops occur on the flank of a regional magnetic anomaly of unknown origin.

Mining activity: Lead-silver mining in vicinity of pluton.

Comment: Pluton near mining activity.

Selected reference: McKee and Marvin, 1976. 
General location: Saxton Peak, Egan Range.

Coordinates: lat $39^{\circ} 16^{\prime} \mathrm{N}$., long $115^{\circ} 00^{\prime} \mathrm{W}$.

Land classification: Patented mining claim.

Area: $8 \mathrm{~km}^{2}$ (cumulative).

Accessibility: Outcrops occur on both north and south sides of U.S. Highway 50. Nevada Northern Railroad north and south of outcrops.

Remoteness: $4 \mathrm{~km}$ west-northwest of Ely (population 6,216).

Geologic setting: The pluton is composed of Cretaceous monzonite porphyry and quartz monzonite porphyry, and intrudes the following: Devonian Guilmette Limestone; Devonian Pilot Shale; Mississippian Joana Limestone and Chainman Shale; Mississippian and Pennsylvanian Ely and Pennsylvanian Riepe Spring Limestones; and Permian Rib Hill Sandstone and Arcturus Formation, composed of limestone, sandstone, and siltstone. Volcanic rocks of Tertiary age partially cover the pluton. The pluton has been dated as $109 \pm 1.5 \mathrm{~m} . \mathrm{y}$. and $115 \pm 3$ m.y. (Hose and others, 1976).

The structure consists of normal faults that intersect both the pluton and the Paleozoic rock. Thrust faults are also present and affect the Paleozoic rocks.

Hydrologic setting: The pluton is in the Steptoe Valley ground-water system and drainage basin. The nearest discharge is $23 \mathrm{~km}$ north, but some ground water may flow southeast toward Murry Spring--about $7 \mathrm{~km}$ from the pluton. Water is used in the valley for livestock, irrigation, and domestic purposes. Murry Spring is part of the water supply for Ely.

Aeromagnetic expression: The granitic rocks occur mainly at the steep northern flank of a high-amplitude positive anomaly. The inferred source of the anomaly is granitic rocks having a maximum areal extent of about $10 \mathrm{~km}^{2}$.

Mining activity: Copper, gold, and silver mining. The granitic intrusives occur near the Ruth open-pit operation.

Comment: Pluton is near mining activity.

Selected references: Hose, Blake, and Smith, 1976; Brokaw, 1967. 
General location: Heusser Mountain, Egan Range.

Coordinates: lat $39^{\circ} 29^{\prime}$ N., long 11452' W.

Land classification: Public domain.

Area: $3 \mathrm{~km}^{2}$.

Accessibility: $7 \mathrm{~km}$ west of U.S. Highway 93 and $3 \mathrm{~km}$ west of Nevada Northern Railroad. Remoteness: $5 \mathrm{~km}$ west of McGill (population 2,164) and $13 \mathrm{~km}$ north of Ely (population $6,216)$.

Geologic setting: The pluton is composed of Tertiary quartz monzonite and intrudes the Precambrian McCoy Creek Group, composed of quartzite, schists, and pelitic rocks. The pluton has been dated as $33.6 \pm 0.7 \mathrm{~m} . \mathrm{y}$.

(Armstrong, 1970a). The structure of the area consists of normal and thrust faults. A major normal fault bounds the pluton on the east; it is downthrown to the east.

Hydrologic setting: The pluton is in the Steptoe Valley ground-water system and drainage basin. The nearest discharge is $8 \mathrm{~km}$ northward; Steptoe Creek is nearby to the east. Water is used in the valley mainly for livestock, domestic, and irrigation purposes.

Aeromagnetic expression: The exposed granitic rocks occur on the western flank of a northnortheast-trending positive anomaly, the source of which may be similar rocks at depth. The maximum areal extent of the inferred buried source is $50 \mathrm{~km}^{2}$.

Selected reference: Armstrong, 1970a. 
WP-10. NORTHERN EGAN RANGE

General location: East flank of the northern Egan Range.

Coordinates: lat $39^{\circ} 38^{\prime}$ N., long $114^{\circ} 52^{\prime} \mathrm{W}$.

Land classification: Public domain.

Area: $25 \mathrm{~km}^{2}$ (cumulative).

Accessibility: $8 \mathrm{~km}$ west of U.S. Highway 93 and $4 \mathrm{~km}$ west of Nevada Northern Railroad.

Remoteness: $25 \mathrm{~km}$ northwest of McGill (population 2,164) and $40 \mathrm{~km}$ north of Ely (population $6,216)$.

Geologic setting: The pluton is composed of Tertiary granite porphyry and quartz monzonite, and intrudes the following: Precambrian McCoy Creek Group, composed of quartzite, schist, and pelitic rocks; Cambrian, Ordovician, and Silurian sedimentary rocks; Devonian Sevy and Simonson Dolomites and Guilmette Formation, which is composed of limestones; DevonianMississippian Pilot Shale, Joana Limestone, and Chainman Shale; Pennsylvanian Ely and Riepe Spring Limestones; and Permian Rib Hill Sandstone and Arcturus Formation, composed of 1 imestone, sandstone and siltstone. The pluton has been dated at 36.2 \pm 0.7 m.y. (Armstrong, 1970a). The structure consists of normal and thrust faults. A major normal fault flanks the pluton to the east; it is downthrown to the east.

Hydrologic setting: The pluton is in the Steptoe and Butte Valleys ground-water systems. Runoff drains to Steptoe and Butte Valleys. The nearest discharge point is $10 \mathrm{~km}$ east in Duck Creek, and the main use of the water is livestock and irrigation.

Aeromagnetic expression: The main granitic rock mass occurs on the northern flank of a northtrending low-amplitude positive anomaly, the source of which may be similar rocks at depth. The maximum areal extent of the buried source is about $15 \mathrm{~km}^{2}$.

Selected reference: Armstrong, 1970a. 
General location: Northernmost end of the Egan Range.

Coordinates: lat $39^{\circ} 49^{\prime}$ N., long $114^{\circ} 53^{\prime} \mathrm{W}$.

Land classification: Public domain, with some private lands and patented mining claims.

Area: $16 \mathrm{~km}^{2}$ (cumulative).

Accessibility: $1 \mathrm{~km}$ west of the end of State Highway $35,14 \mathrm{~km}$ west of U.S. Highway 93 , and

$7 \mathrm{~km}$ west of the Nevada Northern Railroad.

Remoteness: Town of Cherry Creek (population 30) at granitic exposure, 42 km northwest of McGi1l (population 2,164), and $57 \mathrm{~km}$ north of Ely (population 6,216).

Geologic setting: The pluton is composed of Tertiary quartz monzonite and intrudes the

Precambrian McCoy Creek Group, composed of quartzite, schist, and

pelitic rocks; Cambrian and Ordovician-Silurian sedimentary rocks; and

Devonian Pilot Shale, Mississippian Joana Limestone and Chainman Shale.

An average date for the pluton has been determined to be $40.3 \pm 4$ m.y.

(Hose and others, 1976).

A thrust fault is $2 \mathrm{~km}$ west of the northern exposure of the granitic

intrusive. Northwest- and northeast-trending high-angle normal faults

are common. The pluton is bounded on the east by a major normal fault,

downthrown to the east.

Hydrologic setting: The pluton is in the Steptoe Valley ground-water system and water drains

to the Egan Basin tributary, southwest of the town of Cherry Creek.

The nearest discharge is $8 \mathrm{~km}$ northeastward, where the principal use

of the water is for livestock, irrigation, and domestic purposes.

Aeromagnetic expression: A regional low-amplitude positive anomaly is associated with the granitic rocks. The inferred anomaly source is similar rocks at depth, the maximum areal extent of which is estimated to be $25 \mathrm{~km}^{2}$.

Selected reference: Hose, Blake, and Smith, 1976. 
General location: Eastern flank of the Maverick Springs Range.

Coordinates: lat $40^{\circ} 05^{\prime} \mathrm{N}$., long $115^{\circ} 16^{\prime} \mathrm{W}$.

Land classification: Public domain.

Area: $6 \mathrm{~km}^{2}$ (cumulative).

Accessibility: $72 \mathrm{~km}$ north of U.S. Highway 50 and $3 \mathrm{~km}$ northwest of a dirt road:

Remoteness: $145 \mathrm{~km}$ northwest of Ely (population 6,216).

Geologic setting: The pluton is composed of Tertiary quartz monzonite and intrudes the Permian Rib Hill Sandstone and the Park City Group, which is composed of limestone and dolomites.

The major structures are northwest- and northeast-trending high-angle normal faults.

Hydrologic setting: The pluton is in the Ruby Valley ground-water system and closed drainage basin. The nearest discharge occurs $19 \mathrm{~km}$ west, where the water is used for livestock, domestic, irrigation, and wildlife purposes.

Aeromagnetic expression: A short-wavelength low-amplitude anomaly flexure is associated with the exposed granitic rocks. 
General location: West flank of Limestone Peak.

Coordinates: lat $39^{\circ} 10^{\prime} \mathrm{N}$., long $115^{\circ} 17^{\prime} \mathrm{W}$.

Land classification: Public domain, but very near Humboldt National Forest.

Area: $2 \mathrm{~km}^{2}$ (cumulative).

Accessibility: $22 \mathrm{~km}$ south of U.S. Highway 50 and $19 \mathrm{~km}$ northwest of U.S. Highway 6 .

Remoteness: $36 \mathrm{~km}$ southwest of Ely (population 6,216) and $32 \mathrm{~km}$ northwest of Preston.

Geologic setting: The pluton is composed of Tertiary quartz monzonite and is surrounded by

alluvium. The nearest Paleozoic outcrops are the Pennsylvanian Ely

Limestone and the Permian Riepe Spring Limestone, Rib Hi11 Sandstone and

Arcturus Formation, composed of limestone, sandstone, and siltstone.

No structure was mapped in the vicinity of the pluton; however, a north-

east-trending high-angle normal fault system that displaces the Paleozoic

rocks is present west of the pluton.

Hydrologic setting: The pluton is in the White River ground-water system and Jakes Valley drainage basin. The most likely nearby discharge occurs $16 \mathrm{~km}$ south into Ellison Creek tributary. Water is used in the area for livestock, domestic, and irrigation purposes.

Aeromagnetic expression: The granitic rocks occur on a regional, east-trending, low-amplitude nose of a high-amplitude positive anomaly to the west. The positive anomaly source is inferred to be Cretaceous granitic rocks, similar to those designated WP-14.

Selected reference: Brokaw, Bauer, and Breitrick, 1973. 


\section{WP-14. MOUNT HAMILTON}

General location: West flank of Mount Hamilton, White Pine Range.

Coordinates: lat $39^{\circ} 15^{\prime}$ N., long $115^{\circ} 34^{\prime} \mathrm{W}$.

Land classification: Humboldt National Forest, some private lands and patented mining claims. Area: $1 \mathrm{~km}^{2}$ (cumulative).

Accessibility: $16 \mathrm{~km}$ south of U.S. Highway 50.

Remoteness: $58 \mathrm{~km}$ west of Ely (population 6,216).

Geologic setting: Two outcrops occur along the west flank of Mount Hamilton. They are composed of Cretaceous quartz monzonite and intrude limestones and shales of Middle Cambrian age. The pluton has been dated as $90.4 \pm 2$ m.y. (Armstrong, 1970b).

Thrust faults are present $2 \mathrm{~km}$ northeast of the northernmost granitic exposure, and $3 \mathrm{~km}$ southeast of the southernmost exposure. Northeasttrending high-angle normal faults are also present.

Hydrologic setting: The pluton is in the Railroad Valley ground-water system and drainage basin. The nearest discharge is $29 \mathrm{~km}$ south and water is used in the valley primarily for livestock and irrigation purposes.

Aeromagnetic expression: The granitic rocks occur on the steep northern flank of a regional high-amplitude circular positive anomaly, the source of which is inferred to be similar rocks at depth. The maximum areal extent of the source is estimated to be $100 \mathrm{~km}^{2}$.

Selected reference: Armstrong, 1970b. 


\section{WP-15. ALLIGATOR RIDGE}

General location: Northern end of Alligator Ridge.

Coordinates: lat $39^{\circ} 50^{\prime}$ N., long $115^{\circ} 29^{\prime}$ W.

Land classification: Public domain.

Area: $1 \mathrm{~km}^{2}$.

Accessibility: $49 \mathrm{~km}$ north of U.S. Highway 50 and $8 \mathrm{~km}$ west of a dirt road.

Remoteness: $82 \mathrm{~km}$ northwest of Ely (population 6,216).

Geologic setting: The pluton is composed of Tertiary quartz monzonite and intrudes the

Devonian Nevada Formation, composed of quartzite, dolomite, and

limestone. The structure of the area consists of normal faults.

Hydrologic setting: The pluton is in the White River ground-water system and the Long Valley drainage basin. The probable nearest discharge occurs at two wells, 9 and $16 \mathrm{~km}$ south-southeast, where the water is used for livestock.

Aeromagnetic expression: No distinct anomaly is associated with the small exposure. 
WP-16. LITTLE BALD MOUNTAIN

General location: Little Bald Mountain, near Bourne Canyon.

Coordinates: lat $39^{\circ} 57^{\prime}$ N., long $115^{\circ} 33^{\prime} \mathrm{W}$.

Land classification: Public domain,with some patented claims.

Area: $7 \mathrm{~km}^{2}$ (cumulative).

Accessibility: $59 \mathrm{~km}$ north of U.S. Highway 50.

Remoteness: $91 \mathrm{~km}$ northwest of Ely (population 6,216).

Geologic setting: Several outcrops of Tertiary granite and quartz monzonite occur in the

Little Bald Mountain area. The granitic bodies intrude the following:

Middle and Upper Cambrian limestones and shales; Ordovician Pogonip

Group, composed of limestone and quartzite, and Eureka Quartzite;

Ordovician-Silurian sedimentary rocks; and the Devonian Nevada Formation, composed of dolomites and quartzites.

The predominant structures include northwest- and northeast-trending highangle normal faults. Some thrust faults are also present in the area.

Hydrologic setting: The pluton is in the Newark and Ruby Valleys ground-water systems and drainage basins. The nearest discharge occurs $12 \mathrm{~km}$ north, where the water is used for livestock, domestic, wildlife, and irrigation purposes.

Aeromagnetic expression: A low-amplitude negative anomaly flexure overlies the granitic rocks, although no causal relationship is inferred. 
General location: Northern end of the Diamond Mountains.

Coordinates: lat $40^{\circ} 01^{\prime} \mathrm{N}$., long $115^{\circ} 50^{\prime} \mathrm{W}$.

Land classification: Public domain.

Area: Less than $1 \mathrm{~km}^{2}$.

Accessibility: $71 \mathrm{~km}$ north of U.S. Highway 50 and $5 \mathrm{~km}$ east of State Highway 46 (Eureka County).

Remoteness: $117 \mathrm{~km}$ northwest of Ely (population 6,216).

Geologic setting: The pluton is composed of Tertiary quartz monzonite and intrudes the Pennsylvanian Ely and Riepe Spring Limestones. The structure of the area consists of northeast-trending high-angle faults.

Hydrologic setting: The pluton is in the Humboldt River Basin and Diamond Valley ground-water systems. Runoff drains to Huntington and Diamond Valleys. The nearest discharge is $6 \mathrm{~km}$ west in Diamond Valley. Water is used in the valley mainly for livestock, domestic, and irrigation purposes.

Aeromagnetic expression: The small outcrop occurs in a low-amplitude magnetic depression. 
WP-18. PANCAKE RANGE

General location: North end of the Pancake Range.

Coordinates: lat $39^{\circ} 14^{\prime} \mathrm{N}$., long $115^{\circ} 46^{\prime} \mathrm{W}$.

Land classification: Public domain.

Area: $2 \mathrm{~km}^{2}$ (cumulative).

Accessibility: $15 \mathrm{~km}$ south of U.S. Highway 50.

Remoteness: $75 \mathrm{~km}$ west of Ely (population 6,216).

Geologic setting: The pluton is composed of Cretaceous granodiorite and intrudes the Devonian and Mississippian Pilot Shale, and Mississippian Joana Limestone, Chainman Shale and the Diamond Peak Furriation, which is composed of siltstone, claystone and sandstone. The nluton has been dated as $108 \pm 3 \mathrm{~m} . \mathrm{y}$. (Hose and others, 1976).

Northeast- and northwest-trending high-angle normal faults are common in the area. A thrust fault is present southwest of the pluton.

Hydrologic setting: The pluton is in the Newark Valley ground-water system and Little Smoky and Newark Valleys drainage basins. The nearest major discharge is 14 $\mathrm{km}$ northwest in Fish Creek, and the water is used for livestock and domestic purposes.

Aeromagnetic expression: The granitic rock outcrops occur on the southeastern flank of a north-trending positive anomaly having an unknown source. A short-wavelength low-amplitude negative anomaly is centered over the main exposure.

Selected references: Hose, Blake, and Smith, 1976; Nolan, Merriam, and Blake, Jr., 1974. 
GEOLOGY

Elko County (fig. 15), in the northeastern part of the State, lies in the Great Basin and has the typical Basin and Range topography. The southern and western parts of the county are dominated by long, narrow ranges with northerly to northeasterly trends. In the northern part of the county the ranges exhibit a less definite trend, and in the northwest, the Basin and Range province merges with the Columbia River Plateau province. In the northwest, the ranges are irregular in shape and are deeply dissected by stream canyons.

Many of the exposed plutons identified within the county intrude thick sedimentary units of Paleozoic age. The Paleozoic rocks generally belong to two distinct facies. The western facies consist mainly of slate, chert, metamorphosed volcanic rock, and sandstone. The eastern carbonate facies include limestone and dolomite, with minor amounts of quartzite, conglomerate, and shale. Most of the Paleozoic formations have been intensely folded and broken by thrust faults and normal faults. At a few localities, intrusives penetrate Triassic sandstone, shale, and limestone; these sedimentary rocks represent outliers of more extensive formations in Utah.

The plutons in this county range in age from Jurassic to Tertiary and commonly are described as quartz monzonite or granodiorite. The granitic masses situated along the northern border of the State have been described by previous workers as probably being genetically related to the Idaho batholith.

Much of the geologic information concerning the exposures of granitic rocks in Elko County has been abstracted from: Granger, Be11, Simmons, and Lee, 1957.

HYDROLOGY

The northern third of Elko County is drained by north-flowing tributaries to the Snake River of Idaho; these are, from west to east, South Fork Owyhee River, Owyhee River, Bruneau River, Salmon Falls Creek, and Goose Creek, which flows through northwestern Utah enroute to the Snake River. The southwestern quarter of the county is drained by the upper reach of the Humboldt River and its tributaries; the chief tributaries are Huntington Creek, Maggie Creek, Susie-Dorsey Creeks, North Fork Humboldt River, and Lamoille Creek.

The eastern area along the Utah State line, except Goose Creek watershed at the north, drains eastward into the Great Salt Lake Desert. These drainage basin tributaries are called, from north to south, Thousand Springs Creek, Pilot Creek, Great Salt Lake Desert, and Deep Creek. Ruby, Clover, Independence, and Steptoe-Goshute-Antelope Valleys each drain centripetally to topographically closed depressions; also Long and Butte Valleys, both closed, have their northernmost parts in southern Elko County.

Virtually all the higher mountainous area in the northern two-thirds of the county is a major source of runoff and recharge, except the northwestern corner. In the southern third of the county, Ruby Mountains, northern Sulphur Spring and Cherry Creek Ranges, Pequop Mountains, and the Toano-Goshute Ranges are the chief sources of recharge and runoff.

The Humboldt River Basin ground-water system largely coincides with the river's drainage basin and features ground-water movement roughly parallel to streamflow and runoff. 


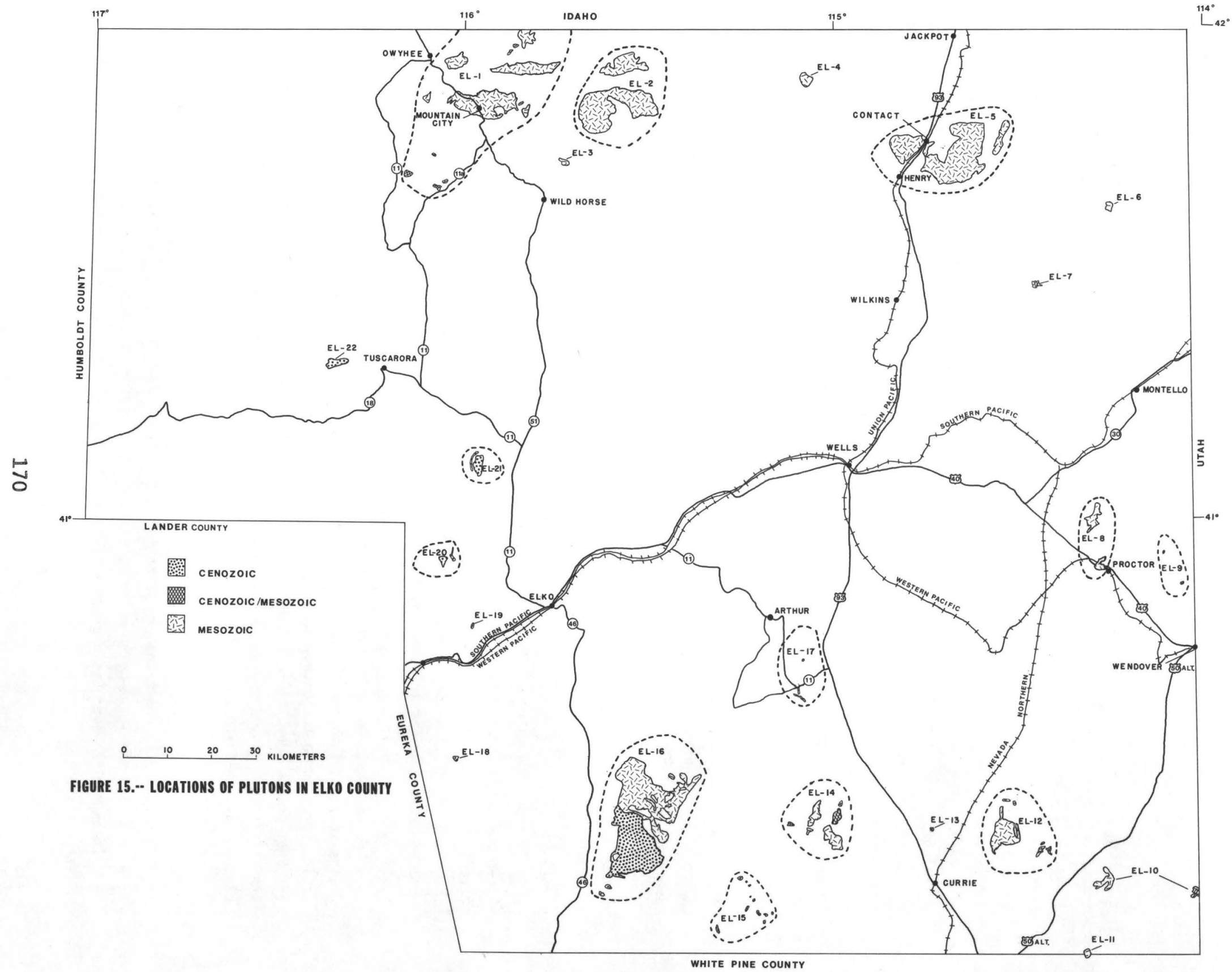


Similarly, ground water moves coincidental with surface water in the five tributaries of the Snake River in northern Elko County, and these stream names are used to designate their associated ground-water systems. The Thousand Springs Creek ground-water system underlies that creek'sdrainage basin in central northeastern Elko County; the system's water moves generally eastward and discharges in Tecoma Valley northeast of Montello. Southward along the Utah State line the Great Salt Lake Desert ground-water system extends westward into Nevada. Some ground water moves from the Steptoe Valley ground-water system eastward into the Great Salt Lake Desert system, but the Steptoe Valley system, including the area under Goshute and Antelope Valleys, is mostly closed hydrologically. Ruby, Clover, Long, Butte, and Independence Valleys ground-water systems are dominantly closed hydrologically, although minor amounts of water move from Clover to Independence and from Butte to Ruby Valleys.

The hydrology of Elko County was taken primarily from the following references: Dudley, 1967; Eakin, 1962e; Eakin and Lamke, 1966; Eakin and Maxey, 1951; Harri11, 1971; Moore and Eakin, 1968; Rush, 1968c; and Rush and Everett, 1966a. 


\section{EL-1. MOUNTAIN CITY DISTRICT}

General location: Northwestern Independence Mountains and northern Bull Run Mountains. Coordinates: lat $41^{\circ} 51^{\prime} \mathrm{N}$., long $115^{\circ} 56^{\prime} \mathrm{W}$. (central mass).

Land classification: Northwestern exposures and the western part of the largest exposure occur on the Duck Valley Indian Reservation. Eastern outcrops are designated Humboldt National Forest lands.

Area: $127 \mathrm{~km}^{2}$.

Accessibility: State Highways 11, 11a, and 51 (43 on p1 1) extend northward from Elko. State Highway 51 crosses over the largest exposure in the Independence Range and is within $16 \mathrm{~km}$ of the extreme northeastern exposures.

Remoteness: The town of Mountain City (population 70) is located on the main exposure, and Owyhee (population 500) is within $3.5 \mathrm{~km}$ of the northwestern exposure.

Geologic setting: Within the Mountain City area several discontinuous outcrops of granodiorite and quartz monzonite are present and extend northward to the Idaho State line. The district includes the Skull Creek, Hicks Mountain and Mountain City plutons (Coats and others, 1965). Workers in the area consider the intrusions to be genetically related to the Idaho batholith. Analyses of samples taken from the Mountain City stock resulted in potassium-argon age dates ranging from 80 to $90 \mathrm{~m} . \mathrm{y}$. (Coats and others, 1965). Lead-alpha analyses yielded ages of $70 \pm 20$ and $110 \pm 15 \mathrm{~m} . \mathrm{y}$. (Schilling, 1965). The discontinuous intrusive bodies generally intrude undifferentiad Antler orogenic sedimentary rocks that include upper Paleozoic siliceous and volcanic assemblages and limestones, conglomerates, and phyllites. Several of the exposures are overlapped by Tertiary volcanic rocks. A few of the outcrops appear to be alined along structural zones of weakness associated with earlier thrusting episodes.

Hydrologic setting: The pluton is in Owyhee River ground-water system and drainage basin.

The river valley is incised into the main exposure of the pluton and some local, intermittent discharge to the river may occur; however, discharge in Duck Valley, near the northwest edge of the pluton and about $15 \mathrm{~km}$ from its center, is the most significant. Use of the water in Duck Valley is for irrigation, livestock, and public supply.

Aeromagnetic expression: The main mass of granitic rocks clearly is associated with a westtrending high-amplitude positive anomaly. The westward extension of the anomaly suggests that plutonic rocks may extend in the subsurface for a distance of as much as $30 \mathrm{~km}$ west of the exposed rocks. The maximum areal extent of the buried source is estimated to be $75 \mathrm{~km}^{2}$.

Mining activity: One silver mine is in operation (1976) near the two southern exposures. Comment: The area occurs within a transition zone between the Columbia River Plateau province and the Basin and Range province.

Selected references: Coats, 1971; Coats, Marvin, and Stern, 1965; and Schi11ing, 1965. 
General location: East of Mountain City, near northern county (and State) border.

Coordinates: lat $41^{\circ} 53^{\prime} \mathrm{N}$., long $115^{\circ} 36^{\prime} \mathrm{W}$. (central location).

Land classification: Humboldt National Forest.

Area: $136 \mathrm{~km}^{2}$.

Accessibility: The southernmost outcrop occurs $17 \mathrm{~km}$ northeast of State Highway 51

(43 on pl. 1).

Remoteness: The prominent outcrop is $23 \mathrm{~km}$ east of Mountain City (population 70 ) and $36 \mathrm{~km}$ southeast of Owyhee (population 500).

Geologic setting: Two extensive Cretaceous exposures of granodiorite in the area (the northern and southern exposures are referred to as the Bearpaw Mountain and Bruneau River plutons, respectively) intrude (1) lower Paleozoic eastern assemblage sediments, composed of quartzite, with minor phyllitic siltstone, limestone, and dolomite; and (2) a lower Paleozoic transitional assemblage, consisting of phyllite, shale, and limestone. The margins of the intrusives are commonly unconformably overlain by Tertiary volcanic rocks.

Near the intrusive contacts the sedimentary assemblages commonly have been metamorphosed to hornfels. Potassium-argon analysis of a sample taken from the Bearpaw Mountain pluton resulted in an age of $73 \mathrm{~m} . \mathrm{y}$. (Coats and others, 1965).

Hydrologic setting: The pluton is in the Bruneau River ground-water system and drainage basin. The most probable nearby discharge is $7 \mathrm{~km}$ northeast into the main channel of the Bruneau River; local springs probably intercept some of the ground-water flow. Use of the water is for livestock and domestic purposes.

Aeromagnetic expression: The northern mass of plutonic rocks has a complex magnetic signature: a broad negative anomaly covering the western twothirds and a circular positive anomaly covering the eastern third. The larger southern mass is clearlv associated with highamplitude positive anomalies, the gradients of which conform to the somewhat arcuate shape of the outcrop pattern. The areal extent of the anomaly source is about the same as that of the exposed southern mass.

Mining activity: Tungsten, silver, and gold mines are active (1976) in an area near the southwest margin of the main exposure.

Comment: The area occurs within a transition zone between the Columbia River Plateau province and the Basin and Range province.

Selected reference: Coats, Marvin, and Stern, 1965; Granger, Bell, Simmons, and Lee, 1957. 


\section{EL-3. COLEMAN CANYON}

General location: Northeast of Wild Horse.

Coordinates: lat $41^{\circ} 44^{\prime} \mathrm{N}$., long $115^{\circ} 43^{\prime} \mathrm{W}$.

Land classification: Humboldt National Forest.

Area: $3 \mathrm{~km}^{2}$.

Accessibility: State Highway 51 (43 on pl 1) passes about $7.5 \mathrm{~km}$ southwest of the pluton.

Remoteness: Mountain City (population 70) and Owyhee (population 500) 1 ie $22 \mathrm{~km}$ and $38 \mathrm{~km}$ northwest of the exposure, respectively.

Geologic setting: A stock of Jurassic-Cretaceous diorite intrudes upper Paleozoic slate, shale, and limestone. Tertiary silicic ash-flow tuffs occur as erosional remnants capping some of the hills in the area.

Hydrologic setting: The pluton is in the Owyhee River ground-water system and drainage basin. The nearest discharge is $8 \mathrm{~km}$ southwest into Wild Horse Reservoir; however, local springs may intercept some ground-water flow. Primary uses of the water are recreation and irrigation, farther downstream.

Aeromagnetic expression: A short-wavelength, low-amplitude, elliptical positive anomaly is centered over the pluton. The areal extent of the anomaly source is about the same as that of the exposed granitic rocks.

Mining activity: Tungsten, silver, and gold mining are active directly north of the stock. 
General location: Northeastern part of county.

Coordinates: lat $41^{\circ} 54^{\prime} \mathrm{N}$., long $115^{\circ} 05^{\prime} \mathrm{W}$.

Land classification: Humboldt National Forest.

Area: $10 \mathrm{~km}^{2}$.

Accessibility: U.S. Highway 93, extending northward from Wells, passes $29 \mathrm{~km}$ southeast of the exposure.

Remoteness: The outcrop occupies an area $29 \mathrm{~km}$ northwest of Contact (population 15) and $33 \mathrm{~km}$ southwest of Jackpot (population 300).

Geologic setting: A circular stock of Cretaceous(?) granodiorite intrudes an isolated horst of Cambrian limestones and dolomites which, in turn, is surrounded by Tertiary rhyolitic flows and welded to nonwelded silicic ash-flow tuffs. Contacts between Tertiary volcanic and Paleozoic sedimentary rocks are marked by normal faults. Tactite, containing molybdenite and scheelite mineralization, has locally developed along the contact between the granodiorite and limestone.

Hydrologic setting: The pluton is in the Salmon Falls Creek ground-water system and drainage basin. The nearest discharge is $9 \mathrm{~km}$ east in North Fork Salmon Falls Creek, and the water is used for livestock and domestic purposes.

Aeromagnetic expression: A very high amplitude, elliptical, positive anomaly is centered at the eastern margin of the outcrop area. Another plutonic rock mass of $10 \mathrm{~km}^{2}$ maximum areal extent may underlie the southeastern part of the anomaly.

Comment: The area occurs within a transition zone between the Columbia River Plateau province and the Basin and Range province.

Selected reference: Coats, Marvin, and Stern, 1965. 


\section{EL-5. CONTACT DISTRICT}

General location: Granite Range, northeast part of county.

Coordinates: lat $41^{\circ} 51^{\prime} \mathrm{N}$. , long $114^{\circ} 40^{\prime}$ W. (central location).

Land classification: In decreasing order of abundance, land designations include public domain, private, and patented mining claims.

Area: $161 \mathrm{~km}^{2}$ (cumulative).

Accessibility: The Union Pacific Railroad and U.S. Highway 93 pass between the two major outcrops.

Remoteness: The town of Contact (population 15) lies within the district, and Jackpot (population 500) is located $20 \mathrm{~km}$ north of the main exposure.

Geologic setting: Several large intrusive masses of Jurassic granodiorite occur within the district and intrude eastern assemblage carbonate rocks of late Paleozoic age. These rocks mainly consist of limestone and shale, with minor amounts of quartzite. The limestone has been silicified and silicated along the contacts. Alaskite dikes cut the granodiorite and Paleozoic rocks. The complex is surrounded by overlapping Tertiary tuffaceous rocks. The pluton has been dated as 150 m.y. by K-Ar methods (Coats and others, 1965).

Hydrologic setting: The district is in Salmon Falls Creek ground-water system and drainage basin, and the creek flows between the two largest granodiorite outcrops. The nearest discharge to the center of the intrusive is $7 \mathrm{~km}$ west in Salmon Falls Creek; however, Meadow Creek, nearer the center of the pluton, may intercept some ground-water flow. Uses made of the water include livestock, domestic, and some irrigation farther downstream.

Aeromagnetic expression: Most of the plutonic rock terrane is associated with a regional west-trending high-amplitude positive anomaly. Another body of plutonic rock, having a maximum areal extent of $50 \mathrm{~km}^{2}$, may underlie the eastern part of the anomaly.

Selected reference: Coats, Marvin, and Sterns, 1965. 


\section{EL-6. DELANO PEAK}

General location: Northeastern part of county.

Coordinates: lat $47^{\circ} 38^{\prime}$ N., long $114^{\circ} 15^{\prime} \mathrm{W}$.

Land classification: Public domain and patented mining claims.

Area: $5 \mathrm{~km}^{2}$.

Accessibility: U.S. Highway 93 and State Highway 30 pass $45 \mathrm{~km}$ west and $37 \mathrm{~km}$ southeast of the outcrop, respectively. The Southern Pacific Railroad roughly parallels

State Highway 30, and the Union Pacific Railroad roughly parallels

U.S. Highway 93.

Remoteness: The outcrop is about $41 \mathrm{~km}$ north of Monte110 (population 150), $51 \mathrm{~km}$ southeast

of Jackpot (population 500), and $81 \mathrm{~km}$ northeast of Wel1s (population 1,081).

Geologic setting: A stock of quartz monzonite and (or) granodiorite intrudes Permian

foreland basinal rocks, predominantly composed of siltstone, sandstone,

limestone, and dolomite. At places, the Permian rocks are unconformably

over?ain by Tertiary tuffaceous rocks. Normal faults constitute the

major structure in the vicinity, of which several cut the intrusive

body.

Hydrologic setting: The pluton is in the Thousand Springs Creek ground-water system and drainage basin. The nearest significant discharge is $28 \mathrm{~km}$ south in Tecoma Valley, but local springs and streams may intercept some ground-water flow near the pluton. Ground water is used for livestock, irrigation, and domestic purposes in the region.

Aeromagnetic expression: The exposure of granitic rock occurs at the northern flank of a broad low-amplitude positive anomaly having an unknown source. 


\section{EL-7. TONY MOUNTAIN}

General location: Northeast part of county, south of Tony Mountain.

Coordinates: lat $41^{\circ} 29^{\prime}$ N., long 114\%27' W.

Land classification: Public domain.

Area: $5 \mathrm{~km}^{2}$.

Accessibility: The intrusive body is $24.5 \mathrm{~km}$ and $28.5 \mathrm{~km}$ east of U.S. Highway 93 and the Union Pacific Railroad, respectively. The Southern Pacific Railroad passes about $30 \mathrm{~km}$ to the south, and State Highway 30 traverses a mountain pass $44 \mathrm{~km}$ to the south.

Remoteness: The town of Montello is $35 \mathrm{~km}$ southeast of the exposure, and Wells lies about

$59 \mathrm{~km}$ to the southwest.

Geologic setting: A small stock of undetermined age intrudes Permian basinal deposits composed of cherty limestone, dolomite, shale, and sandstone. Normal faults are pervasive throughout the Paleozoic strata and cut the intrusive. Tertiary tuffaceous rocks unconformably overlap the Paleozoic sequence.

Hydrologic setting: The pluton is in the Thousand Springs Creek ground-water system and drainage basin. The nearest significant discharge is $26 \mathrm{~km}$ southeast in Tecoma Valley, although local springs and wells may intercept some ground-water flow nearer the pluton. The water is used for livestock, irrigation, and domestic purposes in the area.

Aeromagnetic expression: No single, well-defined anomaly is associated with the pluton. 
General location: Northern Toana Range.

Coordinates: lat $40^{\circ} 57^{\prime} \mathrm{N}$., long $114^{\circ} 18^{\prime} \mathrm{W}$. (central location).

Land classification: Public domain and private lands (railroad).

Area: $16 \mathrm{~km}^{2}$ (cumulative).

Accessibility: The northern exposure is $27 \mathrm{~km}$ southwest of Montello (population 150) and $54.5 \mathrm{~km}$ southeast of Wel1s (population 1,081). The southern exposure lies $27.5 \mathrm{~km}$ northwest of the border town of Wendover (population 60).

Remoteness: U.S. Highway 40 and the Western Pacific Railroad cross over the southern exposure, and the Nevada Northern Railroad extends along Steptoe-Goshute Valleys $9 \mathrm{~km}$ west of the northern exposure.

Geologic setting: Granodiorite of Jurassic age intrudes Cambrian and Ordovician carbonate assemblages, consisting of limestone, dolomite, quartzite, shale, and siltstone. Contacts between the granodiorite and Paleozoic rocks are both intrusive and structural in nature. The western margin of the northernmost outcrop is overlapped by rhyolitic flows. A K-Ar analysis of a sample taken from the pluton resulted in an age of 150 m.y. (Coats and others, 1965).

Hydrologic setting: The pluton is in the Great Salt Lake Desert ground-water system. Runoff flows to Pilot Creek and Goshute Valleys. The nearest discharge is $20 \mathrm{~km}$ east and the water is used for livestock, domestic, and some irrigation purposes.

Aeromagnetic expression: The exposed granitic rock mass fies within a broad low-amplitude negative anomaly, presumably not related to the rocks.

Selected reference: Coats, Marvin, and Stern, 1965. 


\section{EL-9. SOUTHERN PILOT RANGE}

General location: Along the eastern border of the county at the Utah State line and north of Wendover.

Coordinates: lat $40^{\circ} 54^{\prime}$ N., long $114^{\circ} 06^{\prime}$ W. (central location).

Land classification: Public domain.

Area: Less than $2 \mathrm{~km}^{2}$.

Accessibility: The outcrops lie approximately $11 \mathrm{~km}$ and $13 \mathrm{~km}$ northeast of U.S. Highway 40 and the Western Pacific Railroad.

Remoteness: The southern exposure is $15 \mathrm{~km}$ north of Wendover (population 60) and the northern outcrop is $73 \mathrm{~km}$ southeast of Wells (population 1,081).

Geologic setting: Two small exposures of granitic rocks of undetermined age occur along the eastern border of the county. The northern exposure intrudes limestone, dolomite, siltstone, and sandstone of Carboniferous (MississippianPennsylvanian) age. Alluvial fill has covered most of the southern outcrop.

Hydrologic setting: The pluton is in the Great Salt Lake Desert ground-water system and runoff drains to this desert and Pilot Creek, tributary to the desert. Nearest discharge is about $2 \mathrm{~km}$ east of the approximate center of the pluton; the southern outcrop of the pluton is in the discharge area. Water is used in the area for livestock, domestic, and some irrigation purposes.

Aeromagnetic expression: No distinct anomaly is associated with the small outcrop. 


\section{E-10. WHITE HORSE FLAT}

General location: Extreme southeastern part of county.

Coordinates: lat $40^{\circ} 16^{\prime} \mathrm{N} .$, long $114^{\circ} 16^{\prime}$ W. (western exposure).

Land classification: Public domain and patented mining claims.

Area: $10 \mathrm{~km}^{2}$.

Accessibility: U.S. Highway Alternate 50 crosses Antelope Valley $5 \mathrm{~km}$ northwest of the western exposure. The Nevada Northern Railroad passes through Currie about $35 \mathrm{~km}$ to the west.

Remoteness: The western exposure is located $35 \mathrm{~km}$ east of Currie (population 30), and the eastern outcrop is about $54 \mathrm{~km}$ south of Wendover (population 60).

Geologic setting: Two quartz monzonite stocks occur in the White Horse Flat area. A sample taken from the western exposure has been dated as $140(+20,-7)$ m.y. (Schilling, 1965). This exposure is in fault and intrusive contact with Devonian dolomites, limestone, and minor amounts of sandstone and quartzite.

Age of the eastern exposure has not been determined but the stock mainly intrudes Carboniferous (Mississippian and Pennsylvanian) limestone, dolomite, siltstone, and sandstone. To the north, the body is overlain by andesite flows.

Hydrologic setting: The area is predominantly in the Great Salt Lake Desert ground-water system and Great Salt Lake Desert and Antelope Valley drainage basins. The nearest discharge is $32 \mathrm{~km}$ northeast at the Wendover Salt Flat in Utah. The water is not used at the discharge area.

Aeromagnetic expression: The granitic rocks occur on the northwestern flank of an elongate, northwest-trending, high-amplitude positive anomaly, presumably underlain by similar rocks. The maximum areal extent of the inferred source is about $50 \mathrm{~km}^{2}$.

Comment: The eastern outcrop extends eastward across the State line into Utah.

Selected reference: Schilling, 1965. 
General location: Extreme southeastern part of county, south end of Kingsley Mountains. Coordinates: lat $40^{\circ} 07^{\prime} \mathrm{N}$., long $114^{\circ} 21^{\prime} \mathrm{W}$.

Land classification: Public domain and patented mining claims.

Area: $1.5 \mathrm{~km}^{2}$.

Accessibility: The exposure occupies an area $10 \mathrm{~km}$ southeast of U.S. Highway Alternate

50 , and $31 \mathrm{~km}$ east of the Nevada Northern Railroad.

Remoteness: The small town of Currie (population 30) is $36.5 \mathrm{~km}$ northwest of the outcrop. Geologic setting: A stock of quartz monzonite intrudes Cambrian dolomitic limestone. A potassium-argon age of the stock is $35(+5,-2)$ m.y., although a leadalpha determination made on zircon resulted in an age of 41 m.y. (Schilling, 1965). The age of the stock was subsequently revised to $33.4 \pm 0.7$ m.y. (McKee and Marvin, 1976). The intrusive is coarse grained and porphyritic in places but quite uniform in texture between the margins and the center of the stock. Both aplitic and mafic dikes cut the pluton.

Hydrologic setting: The pluton is in the Great Salt Lake Desert ground-water system and the Antelope Valley drainage basin. The nearest discharge is $52 \mathrm{~km}$ northeast in Wendover Salt Flat in Utah, where the ground water is not used.

Aeromagnetic expression: No distinctive anomaly is associated with the pluton.

Selected references: Granger, Bel1, Simmons, and Lee, 1957; McKee and Marvin, 1976; and Schilling, 1965. 
General location: Southeast part of county, northern Antelope Range.

Coordinates: lat $40^{\circ} 21^{\prime} \mathrm{N}$., long $114^{\circ} 32^{\prime} \mathrm{W}$. (central location).

Land classification: Public domain and mining claims.

Area: $39 \mathrm{~km}^{2}$.

Accessibility: The main mass occurs $7 \mathrm{~km}$ southeast of the Nevada Northern Railroad, $15.5 \mathrm{~km}$ northeast of U.S. Highway 93, and $15 \mathrm{~km}$ northwest of U.S. Highway Alternate 50 .

Remoteness: The main exposure is $15 \mathrm{~km}$ northeast of Currie (population 30 ).

Geologic setting: The stock predominantly consists of monzonite and syenite. A potassiumargon age of the stock is $125(+19,-6)$ m.y. (Schilling, 1965). Ages for other isolated bodies southeast of the main mass have been assigned Mesozoic-Cenozoic ages.

The main outcrop intrudes 1 imestone and shale of Permian age. The limestone commonly is thick bedded and relatively unmetamorphosed. The marginal facies of the stock has a finer grain size and usually contains a higher proportion of mafic minerals than the central part of the stock.

Hydrologic setting: The main outcrop is in the Goshute Valley ground-water system and drainage basin. The nearest significant discharge is $10 \mathrm{~km}$ northwest in $\mathrm{Nelson}$ Creek, and the water is used primarily for livestock and domestic purposes. Eastern, small outlying outcrops are in the Great Salt. Lake Desert ground-water system and Antelope Valley drainage basin.

Aeromagnetic expression: A regional northwest-trending high-amplitude positive anomaly clearly is associated with the plutonic rocks. The areal extent of inferred buried rocks near the southern margin of the anomaly is about $50 \mathrm{~km}^{2}$.

Mining activity: Copper mining is active in the area.

Selected references: Granger, Bell, Simmons, and Lee, 1957; Schilling, 1965. 


\section{EL-13. CURRIE}

General location: North of Currie in southeastern part of county.

Coordinates: lat $40^{\circ} 22^{\prime} \mathrm{N}$., long $114^{\circ} 46^{\prime} \mathrm{W}$.

Land classification: Public domain.

Area: Less than $2 \mathrm{~km}^{2}$.

Accessibility: U.S. Highway 93 is $4 \mathrm{~km}$ west and the Nevada Northern Railroad passes $6 \mathrm{~km}$ east of the exposure.

Remoteness: The outcrop lies $11 \mathrm{~km}$ north of Currie (population 30).

Geologic setting: A small circular stock of granociorite(?) is surrounded by Tertiary rhyolitic

flows. The intrusive has beer assigned a Mesozoic-Cenozoic age. Outliers of Triassic clayey sandstone, bentonitic claystone, siltstone, and limestone occur north and west of the stock.

Hydrologic setting: The pluton is in the Goshute Valley ground-water system and drainage basin. The nearest significant discharge is $6 \mathrm{~km}$ east in Nelson Creek. The water is used mainly for livestock and domestic purposes.

Aeromagnetic expression: This pluton occurs on the western flank of the positive anomaly associated with the Dolly Varden stock of EL-12. The anomaly pattern suggests that rocks of the Currie pluton and Dolly Varden stock may be connected at depth despite observed contrasts of mineralogic and petrologic composition. 
General location: Northwest of Currie.

Coordinates: lat $40^{\circ} 23^{\prime} \mathrm{N}$, long $115^{\circ} 03^{\prime} \mathrm{W}$. (central location).

Land classification: Public domain.

Area: $37 \mathrm{~km}^{2}$ (cumulative).

Accessibility: The eastern exposures 1 ie $11 \mathrm{~km}$ west of U.S. Highway 93, and the Nevada

Northern Railroad passes through Currie $22 \mathrm{~km}$ southeast of the largest outcrop.

Remoteness: The main mass occurs $22 \mathrm{~km}$ northwest of Currie (population 30 ).

Geologic setting: A group of exposures of granodiorite and quartz-monzonite occurs in the alluvium of Dry Lake Flat. The larger exposures have been designated as Jurassic in age, whereas the smaller outcrops have been assigned a Mesozoic-Cenozoic age. Cherty limestone and sparse dolomite, shale, and sandstone of Permian age are cut by the eastern granitic rock exposures.

Hydrologic setting: The pluton is in the Ruby Valley closed ground-water system and Ruby and Butte Valleys drainage basins. The nearest discharge point is $24 \mathrm{~km}$ westward. Water is used for livestock, domestic, and wildlife purposes.

Aeromagnetic expression: A regional positive anomaly clearly is associated with the granitic rock exposures, most of which occur on the northern and eastern anomaly flanks. The maximum areal extent of the inferred buried source is about $150 \mathrm{~km}^{2}$. 


\section{EL-15. MAVERICK SPRINGS RANGE}

General location: Northern Maverick Springs Range,

Coordinates: lat $40^{\circ} 15^{\prime} \mathrm{N}$. , long $115^{\circ} 15^{\prime} \mathrm{W}$. (central location).

Land classification: Public domain.

Area: $5 \mathrm{~km}^{2}$ (cumulative).

Accessibility: U.S. Highway 93 is about $40 \mathrm{~km}$ northeast of a central location.

Remoteness: The outcrops are located about $42 \mathrm{~km}$ west of Currie.

Geologic setting: A group of small discontinuous exposures intrude Permian carbonate rocks deposited in a foreland basin. Rock types include cherty limestone, dolomite, shale, siltstone, and sandstone. Normal faults occur throughout the Upper Permian strata and trend in a north to northeast direction. Western exposures appear to be alined along these faults, but any structural association for eastern outcrops is not apparent. Tertiary tuffaceous sedimentary rocks cover parts of the intrusive. (Intrusives have been assigned a Mesozoic-Cenozoic age.)

Hydrologic setting: The pluton is in the Ruby Valley and White River ground-water systems and Ruby and Long Valleys drainage basins. The nearest discharge point is $15 \mathrm{~km}$ west, and water is used in the area for livestock, domestic, and wildlife purposes.

Aeromagnetic expression: No highly distinctive anomalies are associated with the small exposures of granitic rock. 
General location: Southern Ruby Mountains.

Coordinates: lat $40^{\circ} 23^{\prime} \mathrm{N}$., long $115^{\circ} 32^{\prime} \mathrm{W}$. (central mass).

Land classification: Humboldt National Forest (northwestern edge of body is designated as

Area: $253 \mathrm{~km}^{2}$ (cumulative). private land).

Accessibility: State Highway 46 extends northward $5 \mathrm{~km}$ west of the exposure.

Remoteness: The northern limit of the batholith occurs $38 \mathrm{~km}$ south of Elko (population 7,621) and $51 \mathrm{~km}$ southeast of Carlin (population 1,313).

Geologic setting: Granitic intrusives underlying the southern part of the Ruby Mountains have been divided into three episodes of intrusion, beginning with Jurassic, extending through Cretaceous, and culminating in Tertiary time. Several age determinations have been made on samples collected from the youngest part of the complex near Harrison Pass. The dating of biotite from quartz monzonite samples resulted in ages ranging from 26 to $36 \mathrm{~m} . \mathrm{y}$. Lead-alpha determinations on zircon yielded ages ranging from 30 to 40 m.y. (Schilling, 1.965).

To the north, the older Jurassic and Cretaceous segment intrudes a complex intermixture of older Mesozoic metasedimentary rocks and pegmatitic granites.

To the south, the Tertiary intrusion cuts undifferentiated limestone, sandstone, and quartzite of Devonian age.

Workers in the area have described the igneous rocks of Harrison Pass as coarse-grained, porphyritic biotite granite with a marginal facies of medium-grained muscovite-biotite granite. (Note: Dated samples were described as quartz monzonite.)

The major structures in the vicinity include several thrust faults that displace the Paleozoic assemblages south of the Tertiary intrusive mass and a prominent east boundary fault that is discontinuously buried beneath the alluvium of Ruby Valley.

Hydrologic setting: The complex is in the Ruby Valley ground-water system. The area drains to Ruby Valley and Huntington Valley. The nearest discharge area is $8 \mathrm{~km}$ eastward. Water is used in Ruby Valley for livestock, domestic, and wildlife, purposes.

Aeromagnetic expression: Both masses of granitic rock are characterized by extremely low magnetic relief and no distinctive magnetic anomalies.

Comment: Franklin and Ruby Lakes lie in Ruby Valley directly east of the complex.

Selected references: Coats, Marvin, and Stern, 1965; Schi1ling, 1965; Sharp, 1942. 
General location: Southern East Humboldt Range

Coordinates: lat $40^{\circ} 41^{\prime}$ N., long W. $115^{\circ} 06^{\prime}$ W. (central location).

Land classification: Humboldt National Forest, private, and public lands.

Area: $2 \mathrm{~km}^{2}$ (cumulative).

Accessibility: State Highway 11 passes within $5 \mathrm{~km}$ of the outcrops and connects with U.S.

Highway 93 about $5 \mathrm{~km}$ east of the area.

Remoteness: The exposures occur $58 \mathrm{~km}$ southeast of Elko (population 7,621).

Geologic setting: A small group of exposures, composed of diorite of Mesozoic(?) age, cut a sequence of siltstone, sandstone, and limestone, and dolomite of Permian age.

Farther to the north, a small body of Tertiary(?) quartz monzonite(?) intrudes an outlier of Lower Triassic marine deposits composed of siltstone and limestone.

Hydrologic setting: The outcrops are in the Ruby Valley ground-water system and drainage basin. The nearest discharge is $5 \mathrm{~km}$ west of the center of the exposures. Ground water is used in the region for livestock, domestic, and wildlife purposes.

Aeromagnetic expression: No distinctive anomaly is associated with the pluton. 
General location: Southwest edge of county, southeast of Carlin.

Coordinates: lat $40^{\circ} 31^{\prime} \mathrm{N}$., long $116^{\circ} 01^{\prime} \mathrm{W}$.

Land classification: Public domain, private land, and patented mining claims.

Area: $1.5 \mathrm{~km}^{2}$.

Accessibility: The outcrop is about $28 \mathrm{~km}$ southwest of State Highway 51.

Remoteness: The towns of Carlin (population 1,313) and Elko (population 7,621) 1ie $22 \mathrm{~km}$ northwest and $40 \mathrm{~km}$ northeast of the exposure, respectively.

Geologic setting: A small outcrop of Tertiary quartz monzonite intrudes shale, siltstone, sandstone, and conglomerate of the eastern margin of the Antler orogenic belt and the western part of Devonian-Mississippian foreland basin.

Along the western margin, the stock intrudes an older eastern carbonate assemblage consisting of dolomite, limestone, and minor amounts of sandstone and quartzite. The limestone along the intrusive margin has been converted into skarns composed of garnet, epidote, quartz, tremolite, and pyroxene. A potassium-argon age on a sample of quartz monzonite is $33(+5,-2)$ m.y. (Schilling, 1965).

The major structures in the vicinity are thrust faults within the rocks of the Antler orogenic belt west of the stock.

Hydrologic setting: The district is in the Humboldt River Basin ground-water system and the Pine Valley and Dixie Flats drainage basins, tributaries to the Humboldt

River. The nearest discharge is $9 \mathrm{~km}$ west, where water is used for irrigation, domestic, and livestock purposes. Locally, water is used for industrial supply.

Aeromagnetic expression: The exposure of granitic rock occurs on the steep northern flank of an equidimensional high-amplitude positive anomaly having a buried source, possibly of similar plutonic rocks, and an areal extent of about $15 \mathrm{~km}^{2}$.

Selected references: Granger, Be11, Simmons, and Lee, 1957; Schilling, 1965. 


\section{EL-19. ADOBE RANGE}

General location: Northeast of Carlin and west of Elko.

Coordinates: lat $40^{\circ} 48^{\prime} \mathrm{N}$., long 115\%59' W.

Land classification: Private lands.

Area: $2 \mathrm{~km}^{2}$.

Accessibility: The exposure lies $4 \mathrm{~km}$ northwest of U.S. Highway 40 (Interstate 80 ) and the Southern Pacific and Western Pacific Railroads.

Remoteness: Carlin (population 1,313) is $14 \mathrm{~km}$ to the southwest and Elko (population 1,721)

is $18 \mathrm{~km}$ to the northeast.

Geologic setting: A stock of granodiorite(?) intrudes a carbonate sequence of Pennsylvanian and Permian sandy and silty limestone, conglomerate, and siltstone, and a Devonian-Mississippian assemblage of shale, siltstone, sandstone, and conglomerate. Tertiary tuffaceous sedimentary rocks unconformably overlap the stock along its western margin.

Hydrologic setting: The pluton is in the Humboldt River Basin ground-water system and drainage basin. The nearest discharge is $4 \mathrm{~km}$ southeast. Water is used in the valley for irrigation, domestic, and public supply.

Aeromagnetic experssion: A circular low-amplitude, positive anomaly is centered over the pluton. The maximum areal extent of the inferred buried source is $10 \mathrm{~km}^{2}$.

Mining activity: The pluton occurs about $35 \mathrm{~km}$ southeast of the Lynn window, where three gold mines are in operation. 
General location: Southernmost peak of the Independence Mountains.

Coordinates: lat $40^{\circ} 56^{\prime} \mathrm{N}$., long $116^{\circ} 03^{\prime} \mathrm{W}$. (central location).

Land classification: Public and private lands.

Area: $5 \mathrm{~km}^{2}$ (cumulative).

Accessibility: State Highway 11 (also called 51) passes 12 km east, and U.S. Highway 40

(Interstate 80 ) is $19 \mathrm{~km}$ southeast of the outcrops.

Remoteness: The area 1 ies $24 \mathrm{~km}$ northwest of Elko and $22 \mathrm{~km}$ north of Carlin.

Geologic setting: A stock and numerous dikes of quartz monzonite porphyry and biotite granodiorite porphyry intrude (1) Ordovician shales and cherts of the Vinini Formation, (2) Devonian limestone and Silurian limestone (assigned to the Roberts Mountains Formation), and (3) older quartz porphyry. Composition of the intrusive is quartz monzonite and diorite, but is mainly quartz monzonite. Radiometric age of biotite from a sample of quartz monzonite is $38.3 \pm 1.3$ m.y. (Evans and Ketner, 1971). Sedimentary rocks have been metamorphosed adjacent to the larger bodies, and the limestone has been altered to pyroxene-garnet hornfels.

The major structure includes Paleozoic thrust faults that may be segments of the Roberts Mountains thrust and steep pre-01igocene faults that preceded the intrusion.

Hydrologic setting: The pluton is in the Humboldt River Basin ground-water system and Maggie and Susie Creeks drainage basins--tributaries to the Humboldt River. The nearest discharge is $9 \mathrm{~km}$ west, and water is used in the area for livestock and domestic purposes.

Aeromagnetic expression: A circular low-amplitude positive anomaly is centered over the pluton. The maximum areal extent of the inferred buried source is $10 \mathrm{~km}^{2}$.

Selected reference: Evans and Ketner, 1971. 
General location: Northwest of Elko at Lone Mountain.

Coordinates: lat $41^{\circ} 07^{\prime} \mathrm{N}$., long $115^{\circ} 58^{\prime} \mathrm{W}$. (central mass).

Land classification: Public and private lands.

Area: $8 \mathrm{~km}^{2}$ (cumulative).

Accessibility: The main mass occurs $7.5 \mathrm{~km}$ west of State Highway 11 (also called 51).

Remoteness: The southern margin of the main mass lies $33 \mathrm{~km}$ northwest of Elko (population 7,621 ).

Geologic setting: The Nannie's Peak intrusive is an arcuate body of quartz monzonite porphyry that has intruded limestones assigned to the McClellan Creek sequence (Devonian?). Near the intrusive margin the limestones become increasingly deformed and in many palces are silicified. Geochemical age analyses, based on the potassium-argon method, resulted in an age of $12 \mathrm{~m} . \mathrm{y}$. (Lovejoy, 1959).

Hydrologic setting: The intrusive is in the Humboldt River Basin ground-water system and Susie Creek and North Fork of Humboldt River drainage basins, tributaries to the Humboldt River. The nearest discharge is $10 \mathrm{~km}$ northeast. Water is used for livestock and domestic purposes.

Aeromagnetic expression: The granitic rocks occur at the northeastern flank of a high-amplitude positive anomaly. The buried source is likely similar granitic rock having a maximum areal extent of about $15 \mathrm{~km}^{2}$.

Selected reference: Lovejoy, 1959. 
General location: West of Tuscarora.

Coordinates: lat $41^{\circ} 19^{\prime} \mathrm{N}$., long 116 $20^{\prime} \mathrm{W}$.

Land classification: Public and private lands.

Area: $7 \mathrm{~km}^{2}$.

Accessibility: The eastern margin of the body lies about $8 \mathrm{~km}$ west of State Highway 18 and $17.5 \mathrm{~km}$ northwest of the intersection of Highway 18 and State Highway 11.

Remoteness: The intrusive occupies an area $8.5 \mathrm{~km}$ west of Tuscarora (population 50 ) and $75 \mathrm{~km}$ northwest of E1ko (population 7,621).

Geologic setting: A stock of Tertiary granodiorite intrudes volcanic and siliceous rocks of Ordovician age. These latter rocks generally include chert, shale, quartzite, greenstone, and minor amounts of limestone. The northern margin of the pluton is overlapped by Tertiary welded and nonwelded silicic ash-flow tuffs. The stock has been dated as $38.4 \pm 1.5 \mathrm{~m} . \mathrm{y}$. (McKee and Marvin, 1976).

Hydrologic setting: The pluton is in the Humboldt River Basin and South Fork Owyhee River ground-water systems. Runoff drains to Independence Valley and Willow Creek. The nearest discharge is $10 \mathrm{~km}$ east in Independence Valley. The water is used in the valley for domestic, livestock, and irrigation. Aeromagnetic expression: The exposure of granitic rock clearly is associated with a highamplitude positive anomaly having a buried counterpart with a maximum areal extent of $75 \mathrm{~km}^{2}$.

Selected reference: McKee and Marvin, 1976. 


\section{GEOLOGY}

Humboldt County (fig. 16) is located in the northwestern part of the State where the southern and central parts of the county have topography typical of the Basin and Range province. The northeastern part of the county is a broad plateau underlain by volcanic rocks and is the southern extension of the Columbia River Plateau province. The northwestern part of the county is also a broad plateau that appears to be a transition zone between the Columbia River Plateau province on the north and the Basin and Range province on the south (Willden, $1964)$.

Rocks of Cambrian, Ordovician, Mississippian, Pennsylvanian, Permian, Triassic, Jurassic(?), Cretaceous, and Tertiary age are found in the county.

The Cambrian, Ordovician, Mississippian, and Pennsylvanian rocks are found in the southeast part of the county and consist of clastic sedimentary rocks, with some carbonate and basic volcanic rocks. The Permian rocks consist of carbonate rocks, sandstone, chert, shale, conglomerate, and basic volcanic rocks (Willden, 1964).

Triassic rocks are found in the central part of the county and consist of fine-grained clastic rocks and some quartzite and limestone.

Cretaceous rocks consist of sandstone, siltstone, conglomerates, and granitic intrusives all of which are found throughout the county.

Tertiary rocks consist of rhyolitic to dacitic welded tuffs and lava flows.

The regional structure of the county is not well known (Willden, 1964). Four periods of compressive deformation have affected the area (Willden, 1964), followed by normal faulting during the Tertiary. The Paleozoic rocks were folded and thrust faulted during the Antler orogeny (Late Devonian or Early Mississippian time) and again in Permian time. Triassic rocks were then folded and thrust faulted, followed by deformation of Cretaceous rocks in Late Cretaceous or early Tertiary time. Tertiary Basin and Range faults were superposed on the older structure complex.

The Oregon-Nevada lineament ( $\mathrm{pl} \mathrm{4}$ ) is located in the northeastern part of the county. The belt consists of closely spaced, partly en echelon faults that extend from Oregon into Nevada. The segment of the lineament in Nevada is composed of closely spaced north-northwesttrending faults.

The geologic data were extracted and summarized from the following: Willden, Ronald, 1964.

\section{HYDROLOGY}

The Quinn River drainage area, which heads in southeastern Oregon and terminates in the Black Rock Desert, drains about one-third of central and southwestern Humboldt County. The Humboldt River Basin drains the southeastern and east-central part of Humboldt County--amounting in area to about one-fourth of the county. Most of northwestern Humboldt County is drained by a group of easterly flowing creeks, mainly Virgin, Thousand, and Craine Creeks, that turn northward into Oregon near Denio, Nev. Upper tributaries of the Owyhee River of southwestern 


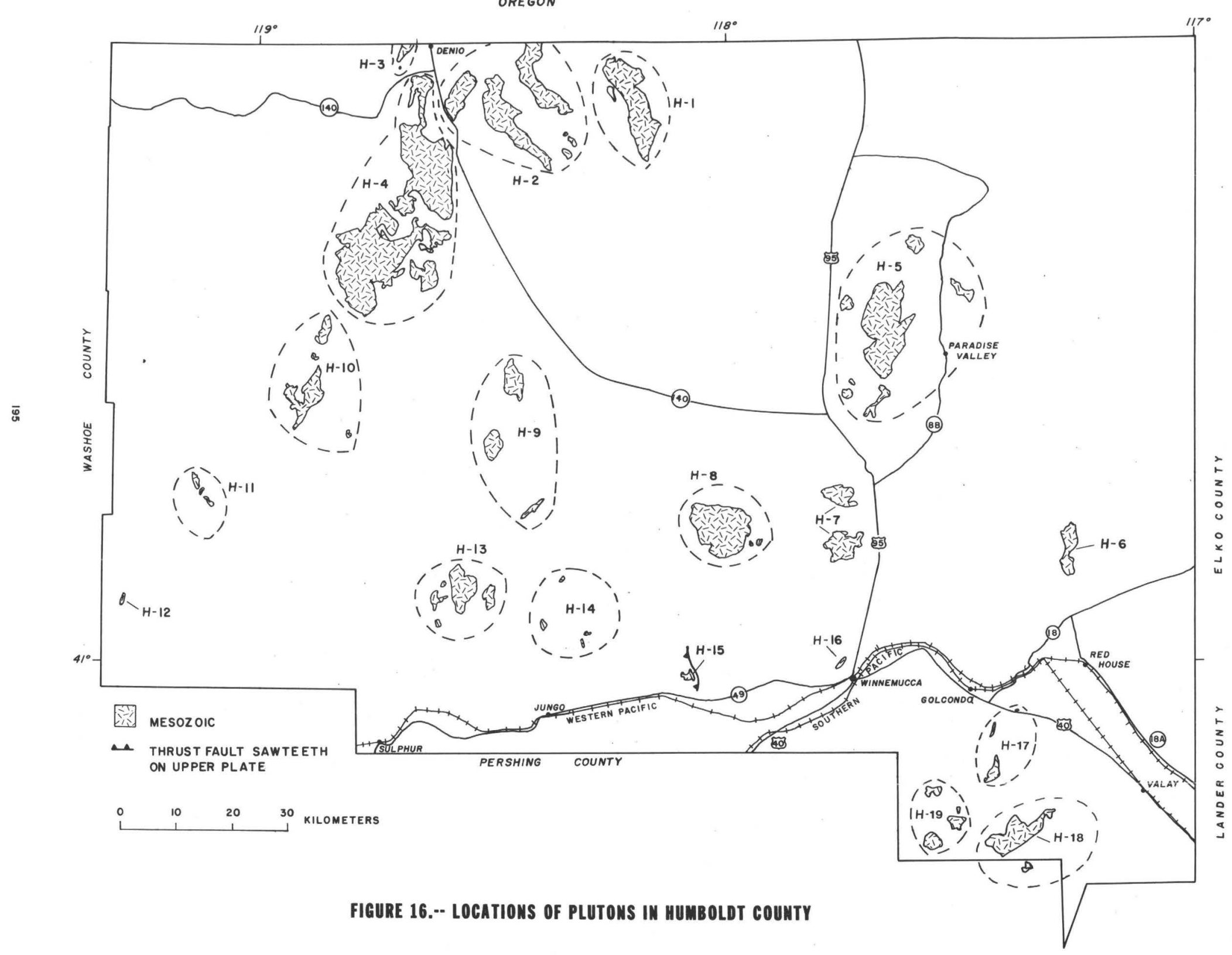


Idaho drain northeastern Humboldt County. Locally, centripetal drainage occurs in southern Desert and Silver State Valleys; parts of both these valleys drain north to Quinn River. Hualapai Flat (Alkali Flat), largely in southwesternmost Humboldt County, is an area of internal drainage.

All the peaks higher in altitude than about $1,981 \mathrm{~m}$ in the northern half of Humboldt County are significant sources of runoff and recharge; the largest single mass in that area is the Santa Rosa Range and contiguous mountains in the northeastern part of the county. In the southern half of the county the Osgood Mountains, Sonoma Range, Bloody Run Hills, Jackson Mountains, southern Black Rock Range, and Calico Mountains are the chief sources of recharge.

Ground water moves in general accord with surface-water runoff in the Quinn River drainage area (including Black Rock Desert) and in the Humboldt River Basin. In the Quinn River drainage area, two ground-water systems are designated: Black Rock Desert ground-water system below the narrows near the town of Quinn River Crossing and Quinn River ground-water system upstream (eastward) from that point. Ground water also moves parallel to surface drainage in northwestern Humboldt County and some of this ground water moves into Oregon, particularly at Denio and at three places in extreme northwestern Humboldt County. In the Owyhee River drainage of northeastern Humboldt County, ground water presumably moves with surface-water drainage and some of it migrates into southern Idaho along the State line farther east in Elko County. Desert and Silver State Valleys leak some ground water northward into the Quinn River ground-water system.

The hydrology of Humboldt County was taken primarily from the following reports: Harrill and Moore, 1970; Sinclair, 1962a; Sinclair, 1962b; Sinclair, 1963a; Sinclair, $1963 \mathrm{~b}$; and Visher, 1957. 


\section{H-1. DISASTER PEAK}

General location: Northern part of the Trout Creek Mountains (Montana Mountains) near

Disaster Peak.

Coordinates: lat $41^{\circ} 51^{\prime} \mathrm{N} .$, long $118^{\circ} 11^{\prime} \mathrm{W}$.

Land classification: Public domain.

Area: $93 \mathrm{~km}^{2}$ (cumulative).

Accessibility: $31 \mathrm{~km}$ east of State Highway 140, and $37 \mathrm{~km}$ west of U.S. Highway 95.

Remoteness: $30 \mathrm{~km}$ southeast of Denio (population 20) and $97 \mathrm{~km}$ northwest of Winnemucca

(population 3,587); northernmost exposure is $3 \mathrm{~km}$ south of Oregon border.

Geologic setting: The pluton is composed of Cretaceous granodiorite and is locally intruded

by alaskite. The granitic mass is overlain unconformably by Tertiary volcanic rocks that include rhyolitic to dacitic lava flows and welded tuffs, and basalts and andesitic lava flows.

The Trout Creek Mountains form a volcanic range that has been uplifted and is bounded by high-angle normal faults along the west and northwest part of the range. The pluton along the western flank of the range is bounded and, in some areas, cut by the high-angle normal faults. A high-angle normal fault just south of the pluton appears to cut the alluvium.

Hydrologic setting: The pluton is in the Quinn River ground-water system and the Kings River drainage basin, tributary to Quinn River. The nearest discharge point is $11 \mathrm{~km}$ southwest near the Kings River. Ground water is used in the region for livestock, irrigation, and domestic purposes.

Aeromagnetic expression: A northwest-trending series of high-amplitude positive anomalies is clearly associated with the pluton. The southeastward continuation of this anomaly pattern, including a regional high-amplitude positive anomaly centered about $35 \mathrm{~km}$ southeast of the exposure, may be caused by one or a combination of exposed extrusive rocks or buried granitic rocks. Regardless of the lithologic character of the buried source, its areal extent is about that of the area of outcrop.

Comment: High-angle normal faults disrupt Quaternary alluvium near pluton. 


\section{H-2. BILK CREEK MOUNTAINS (Kings River Range)}

General location: Northern part of the Bilk Creek Mountains (Kings River Range).

Coordinates: lat $41^{\circ} 52^{\prime}$ N., long $118^{\circ} 30^{\prime} \mathrm{W}$.

Land classification: Public domain, with some private lands.

Area: $131 \mathrm{~km}^{2}$ (cumulative).

Accessibility: State Highway 140, just south of western outcrop.

Remoteness: $7 \mathrm{~km}$ southeast of Denio (population 20); pluton extends into Oregon.

Geologic setting: The Bilk Creek Mountains pluton is composed of several exposures of

Cretaceous granodiorite. The granitic mass is overlain unconformably

by volcanic rocks that include rhyolitic to dacitic lava flows and welded tuffs, and basalts and andesitic lava flows of Tertiary age.

A prominent northwest-trending high-angle normal fault system in the area affects both the volcanic and granitic intrusives. A less prominent northeast-trending high-angle fault system is also present in the area.

Hydrologic setting: The pluton is in the Black Rock Desert and Quinn River ground-water systems, and the nearest discharge to the center of the granitic mass is about $16 \mathrm{~km}$ southeast in Kings River. Runoff drains mainly to the Kings River and Black Rock Valleys. Ground water is used in the region for livestock, domestic, and irrigation purposes.

Aeromagnetic expression: The granitic rocks are generally associated with several shortwavelength positive anomalies that are presumably caused in large part by basaltic flows and ash-flow tuffs. 


\section{H-3. PUEBLO MOUNTAINS}

General location: East flank of the Pueblo Mountains.

Coordinates: lat $41^{\circ} 59^{\prime} \mathrm{N} .$, long $118^{\circ} 41^{\prime} \mathrm{W}$.

Land classification: Public domain, with some patented mining claims.

Area: $4 \mathrm{~km}^{2}$.

Accessibility: $3 \mathrm{~km}$ north of State Highway 140.

Remoteness: $3 \mathrm{~km}$ west of Denio (population 20), and $136 \mathrm{~km}$ northwest of Winnemucca

(population 3,587). Pluton extends into Oregon.

Geologic setting: The Pueblo Mountains pluton is composed of Cretaceous quartz diorite and intrudes chlorite schist, hornfels, quartz-mica schist, and marble of Permian-Triassic age. The pluton is overlain unconformably by basaltic and andesitic volcanic rocks of Tertiary age. The pluton has been dated as $92.4 \pm 1.3 \mathrm{m.y}$. (Harrold, 1972).

The Pueblo Mountains area is an uplifted fault block, bounded on the east by a high-angle normal fault. The Permian-Triassic, Tertiary, and granitic rocks are all offset by high-angle normal faults.

Hydrologic setting: The pluton is in the Continental Lake and Pueblo Valley ground-water systems and drainage basins. The nearest discharge is $5 \mathrm{~km}$ south, near Continental Lake. The water is used for livestock and domestic purposes.

Aeromagnetic expression: The outcrop of granitic rocks occurs at the site of a doubly-1obed, short-wavelength, positive anomaly that presumably has a composite extrusive and intrusive rock source. The maximum areal extent of the buried source (Nevada part) is estimated to be $1-5 \mathrm{~km}^{2}$.

Selected reference: Harrold, 1972. 


\section{H-4. DUFFER PEAK}

General location: Duffer Peak, Pine Forest Range.

Coordinates: lat $41^{\circ} 40^{\prime}$ N., long $118^{\circ} 45^{\prime}$ W.

Land classification: Public domain, with some private lands.

Area: $364 \mathrm{~km}^{2}$ (cumulative).

Accessibility: Northernmost outcrop is $1 \mathrm{~km}$ south of State Highway 140, southernmost outcrop

is $26 \mathrm{~km}$ west of State Highway 140 .

Remoteness: $102 \mathrm{~km}$ northwest of Winnemucca (population 3,587) and $5 \mathrm{~km}$ south of Denio

(population 20). Northernmost outcrop is $5 \mathrm{~km}$ south of Oregon border.

Geologic setting: The pluton is composed of Cretacersus granodiorite and some quartz diorite; it intrudes the Hapoy Creek volcanics (Permian or older); TriassicJurassic limestone, phyllite, slate, and quartzite; and is overlain unconformably by basaltic, andesitic, dacitic, and rhyolitic Tertiary volcanic rocks. Alluvium bounds the pluton to the east and northeast. The pluton has been dated as $93.6 \pm 1.5$ m.y., 101 \pm 2.0 m.y., and $107 \pm 2.1$ m.y. (Harrold, 1972).

The structure consists of high-angle normal faults that cut the pluton in some areas, and thrust faults in the vicinity of the pluton.

Hydrologic setting: The pluton is principally in the Black Rock Desert ground-water system, where the nearest discharge is $27 \mathrm{~km}$ southeast near the Quinn River. Half the area drains eastward into Black Rock Desert basin and half drains to Gridley Lake basin, to the northwest, where some of the ground water flows. Ground water in the region is used primarily for livestock and domestic purposes, and a small amount is used for irrigation.

Aeromagnetic expression: The granitic rock terrane has a highly complex magnetic signature. Anomalies over the granodiorites are generally negative, although several short-wavelength positive anomalies are developed, partly caused by extrusive rocks. High-amplitude positive anomalies are associated with the diorites, reflecting their higher intensity total magnetizations, relative to those of the granodiorites.

Selected reference: Harrold, 1972. 


\section{H-5. SANTA ROSA PEAK}

General location: Santa Rosa Peak, central part of the Santa Rosa Range.

Coordinates: lat $41^{\circ} 32^{\prime} \mathrm{N}$., long $117^{\circ} 38^{\prime} \mathrm{W}$.

Land classification: Predominantly Humboldt National Forest, with some private lands.

Area: $133 \mathrm{~km}^{2}$ (cumulative).

Accessibility: Main outcrop is $6 \mathrm{~km}$ east of U.S. Highway 95, and $5 \mathrm{~km}$ west of State Highway $8 B$.

Remoteness: Main outcrop is $53 \mathrm{~km}$ north of Winnemucca (population 3,587).

Geologic setting: The Santa Rosa Peak pluton is composed of scattered exposures of Cretaceous granodiorite. The granitic mass intrudes the following: Triassic Grass Valley Formation, which consists of shale, quartzite, and limestone lenses; Triassic Winnemucca Formation, composed of shale, slate, carbonate rocks, sandstone, and quartzite; and Triassic Raspberry Formation, which consists of phyllite, limestone lenses, and quartzite. Some of the granitic exposures are overlain unconformably by Tertiary andesitic, basaltic, dacitic, and rhyolitic volcanic rocks. The granitic intrusives have metamorphosed the surrounding country rocks to schist and hornfels, and have been dated as $97.8 \pm 3$ m.y. and $99.5 \pm 5$ m.y. (Silberman and McKee, 1971).

The Triassic rocks have been folded and form a complex of anticlines and synclines. Minor thrust faults are associated with folding of the Triassic rocks. Basin and Range faults have uplifted the area and high-angle normal faults offset the granitic masses.

Hydrologic setting: The pluton is in the Humboldt River Basin and Quinn River ground-water systems. Runoff drains to Paradise and Quinn River Valleys. The nearest discharge point is $9 \mathrm{~km}$ eastward. The water is used for irrigation, livestock, and domestic purposes.

Aeromagnetic expression: The main mass of granitic rocks has a highly complex magnetic signature, being associated partly with negative and partly with positive anomalies. The smaller outcrops tend to occur on the flanks of various other anomalies.

Mining activity: Tungsten mining in southern part of the Santa Rosa Range.

Comment: Tungsten mining near pluton.

Selected reference: Silberman and McKee, 1971. 
General location: Northern part of the Osgood Mountains at Adam Peak.

Coordinates: lat $41^{\circ} 10^{\prime} \mathrm{N}$. , long $117^{\circ} 15^{\prime} \mathrm{W}$.

Land classification: Private lands and public domain.

Area: $19 \mathrm{~km}^{2}$ (cumulative).

Accessibility: $32 \mathrm{~km}$ east of U.S. Highway 95, and $7 \mathrm{~km}$ north of State Highway 18.

Remoteness: $27 \mathrm{~km}$ northeast of Golconda (population 200), and $42 \mathrm{~km}$ northeast of Winnemucca (population 3,587).

Geologic setting: The pluton is composed of Cretaceous granodiorite that intrudes the Cambrian Preble Formation, which is composed of shale, limestone, and quartzite. The granodiorite intrusive has metamorphosed the shaly rocks to phyllite, slaty hornfels, and schist, and the limestones to marble and tungsten-bearing tactite. Other units in the vicinity include the Osgood Mountain Quartzite, and Harmony, Comus, and Valmy Formations, all of early Paleozoic age. The granodiorite has been dated as $88.3 \pm 1.8 \mathrm{m.y.}, 89.9 \pm 1.8 \mathrm{m.y.}$, and $92.2 \pm 1.8 \mathrm{m.y.}$ (Silverman and McKee, 1971).

The area consists of a complex of thrust faults associated with high-angle normal faults. Tertiary faults consist of high-angle faults and some folds. A high-angle normal fault located approximately $4 \mathrm{~km}$ southeast of the pluton cuts the alluvium.

Hydrologic setting: The pluton is in the Humboldt River Basin ground-water system and runoff drains to Kelly Creek and Eden Valley Basins. The nearest discharge point is $10 \mathrm{~km}$ southeast. The water is used for irriqation, livestock, and public supply.

Aeromagnetic expression: An elliptical, north-trending, high-amplitude positive anomaly is centered directly over the granitic rock exposure. The maximum areal extent of the inferred buried source is about $5 \mathrm{~km}^{2}$.

Comment: The Getchell fault cuts the eastern flank of the granodiorite and sedimentary rocks. Disseminated gold deposits occur locally along the fault. A fault, cuts alluvium approximately $4 \mathrm{~km}$ southwest of the pluton.

Selected references: Silberman and McKee, 1971; Silberman, Berger, and Koski, 1974. 
H-7. BLOODY RUN HILLS

General location: Bloody Run Hills, southern part of the Santa Rosa Range.

Coordinates: lat $41^{\circ} 10^{\prime} \mathrm{N}$., long $117^{\circ} 44^{\prime} \mathrm{W}$.

Land classification: Private lands and public domain.

Area: $37 \mathrm{~km}^{2}$ (cumulative).

Accessibility: $2 \mathrm{~km}$ west of U.S. Highway 95.

Remoteness: $21 \mathrm{~km}$ northwest of Winnemucca (population 3,587).

Geologic setting: The pluton is composed of two exposed Cretaceous granodiorite bodies that intrude the Triassic Singas Formation, composed of phyllite, limestone lenses, and quartzites. The intrusive body has metamorphosed the country rock to schists and hornfels. The Triassic rocks and the granodiorite both have been intruded by large diabase dikes and andesitic, dacitic, and rhyolitic dikes.

The Bloody Run Hills lie on a steeply dipping and locally overturned northwest $1 \mathrm{imb}$ of a fold (Willden, 1964). Minor Tertiary high-angle normal faults are present.

Hydrologic setting: The pluton is in the Humboldt River Basin and Quinn River ground-water systems. Runoff drains to Paradise Valley and Silver State Valley Basins. The nearest discharge point is $11 \mathrm{~km}$ east, near the Little Humboldt River. The water is used for irrigation, livestock, and domestic purposes.

Aeromagnetic expression: The two granitic rock exposures are each clearly associated with oval, high-amplitude positive anomalies. The inferred areal extents of the anomaly sources are about the same as the areas of outcrop.

Selected reference: Willden, 1964 . 
H-8. SLUMBERING HILLS

General location: Central part of the Slumbering Hills.

Coordinates: lat $41^{\circ} 13^{\prime} \mathrm{N}$., long $118^{\circ} 00^{\prime} \mathrm{W}$.

Land classification: Public domain, with some private lands.

Area: $76 \mathrm{~km}^{2}$ (cumulative).

Accessibility: $23 \mathrm{~km}$ west of U.S. Highway 95.

Remoteness: $30 \mathrm{~km}$ northwest of Winnemucca (population 3,587).

Geologic setting: The pluton is composed of Mesozoic (Cretaceous?) granodiorite and intrudes phyllite, slate, and quartzite of Triassic-Jurassic age and is overlain unconformably by basaltic and andesitic volcanic rocks. The structure consists of high-angle normal faults.

Hydrologic setting: The pluton is in the Quinn River ground-water system. Runoff drains to Silver State Valley on the east and Desert Valley on the west. The nearest discharge is about $18 \mathrm{~km}$ north near the Quinn River. The water is used for livestock, domestic, and some irrigation.

Aeromagnetic expression: The granitic rock exposure occurs at the northeastern margin of a regional west-trending high-amplitude positive anomaly. It is inferred that similar plutonic rocks extend westward for a distance of $20 \mathrm{~km}$ and southward for a distance of $10 \mathrm{~km}$. The subsurface plutonic rock terrane may also extend continuously to the outcrops of the Jungo Hills pluton of $\mathrm{H}-14,25 \mathrm{~km}$ to the southwest. The maximum areal extent of the cumulative sources of anomalies is estimated to be $200-300 \mathrm{~km}^{2}$.

Mining activity: Gold mining just north of pluton.

Comment: Mining activity near pluton. 
General location: North part of the Jackson Mountains.

Coordinates: lat $41^{\circ} 22^{\prime} \mathrm{N}$., long 118 $28^{\prime} \mathrm{W}$.

Land classification: Public domain, with some private lands and patented mining claims.

Area: $32 \mathrm{~km}^{2}$ (cumulative).

Accessibility: Northern outcrop $9 \mathrm{~km}$ southwest of State Highway 140, southern outcrop $22 \mathrm{~km}$ southwest of State Highway 140.

Remoteness: Northern outcrop is $56 \mathrm{~km}$ southeast of Denio (population 20) and $73 \mathrm{~km}$ northwest of Winnemucca (population 3,587).

Geologic setting: The pluton is composed of Mesozoic (Cretaceous?) granodiorite. Included with the granodiorite pluton are diorite intrusives of Jurassic-Cretaceous age. The granodiorite and diorite intrusives intrude the Permian or older Happy Creek Volcanics; Permian-Triassic volcanic and sedimentary rocks; and Cretaceous King Lear Formation; the intrusives are overlain unconformably by basaltic and andesitic volcanic rocks of Tertiary age. The structure of the area consists of high-angle normal faults.

Hydrologic setting: The pluton is main?y ir the Black Rock Desert ground-water system and drainage basin. The nearest discharge point is $9 \mathrm{~km}$ west, near the Quinn River. The southeastern part of the pluton drains to Desert Valley. Ground water is used in the region for livestock and domestic purposes.

Aeromagnetic expression: High-amplitude north-northeast-trending positive anomalies are associated with the three main masses of granitic rock. The maximum areal extent of the buried source rocks is estimated to be about $35 \mathrm{~km}^{2}$. 
H-10. BATTLE CREEK

General location: East flank of the northern part of the Black Rock Range at Battle Creek. Coordinates: lat $41^{\circ} 26^{\prime} \mathrm{N}$., long $118^{\circ} 53^{\prime} \mathrm{W}$.

Land classification: Public domain, with some private lands.

Area: $34 \mathrm{~km}^{2}$ (cumulative).

Accessibility: $40 \mathrm{~km}$ southwest of State Highway 140.

Remoteness: $106 \mathrm{~km}$ northwest of Winnemucca (population 3,587).

Geologic setting: The pluton is composed of Cretaceous granodiorite and is overlain unconformably by basaltic and andesitic volcanic rocks of Tertiary age.

Other rock types in the area include rhyolitic and dacitic rocks of Tertiary age. High-angle normal faults bound the pluton on the southeast and cut the granodiorite body.

Hydrologic setting: The pluton is in the Black Rock Desert ground-water system and drainage basin, and the nearest discharge point is $28 \mathrm{~km}$ south-southeast along the Quinn River. Ground water is used in the region for livestock and domestic purposes.

Aeromagnetic expression: Two high-amplitude positive anomalies are associated with the various exposures of granitic rock. The anomalies may be caused by a combination of intrusive and extrusive rocks. 


\section{H-11. PAHUTE PEAK}

General location: Pahute Peak is within the Black Rock Range:

Coordinates: lat $41^{\circ} 17^{\prime} \mathrm{N}$., long $119^{\circ} 07^{\prime} \mathrm{W}$.

Land classification: Public domain.

Area: $5 \mathrm{~km}^{2}$ (cumulative).

Accessibility: $24 \mathrm{~km}$ northeast of State Highway 34 (Washoe County).

Remoteness: $51 \mathrm{~km}$ northwest of Sulphur, and $116 \mathrm{~km}$ northwest of Winnemucca (population 3,587).

Geologic setting: The pluton is composed of Mesozoic (Cretaceous?) granodiorite and is overlain unconformably by volcanic and sedimentary rocks of Tertiary age. The granodiorite body is bounded on the southwest by a high-angle normal fault.

Hydrologic setting: The pluton is in the Black Rock Desert ground-water system and drainage basin. The nearest discharge point is $18 \mathrm{~km}$ south in the playa. Water is used in the region for livestock and domestic purposes.

Aeromagnetic expression: The granitic rock outcrops occur on the southwestern flank of a regional, northwest-trending, high-amplitude positive anomaly, which is inferred to have a composite source of extrusive and intrusive rocks. 
H-12. DONNELLY PEAK

General location: Donnelly Peak, Calico Mountains.

Coordinates: lat $41^{\circ} 06^{\prime}$ N., long $119^{\circ} 16^{\prime} \mathrm{W}$.

Land classification: Public domain.

Area: $2 \mathrm{~km}^{2}$.

Accessibility: $8 \mathrm{~km}$ east of State Highway 34 (Washoe County).

Remoteness: $52 \mathrm{~km}$ northwest of Sulphur, and $130 \mathrm{~km}$ west of Winnemucca (population 3,587).

Geologic setting: The Donnelly Peak pluton is composed of Mesozoic (Cretaceous?)

granodiorite and intrudes phyllite, slate, and quartzite of Triassic-

Jurassic age. The pluton is overlain unconformably by Tertiary volcanic

rocks that include basaltic, andesitic, lava flows, and rhyolitic to dacitic welded tuffs.

The area has been uplifted and tilted eastward. The pluton is bounded on the west by a high-angle normal fault.

Hydrologic setting: The pluton is in the Black Rock Desert ground-water system. Runoff drains partly to the Black Rock Desert and partly to Hualapai Flat (Alkali

Flat) drainage basins. The nearest discharge point is east $13 \mathrm{~km}$, at the edge of a playa flat. Ground water is used in the region principally for livestock and domestic purposes.

Aeromagnetic expression: The small granitic rock exposure occurs on the northern flank of an elliptical, short-wavelength, high-amplitude, positive anomaly. The maximum areal extent of the inferred plutonic rock source is about $1-5 \mathrm{~km}^{2}$. 
General location: Southern part of the Jackson Mountains at Navajo Peak.

Coordinates: lat $41^{\circ} 08^{\prime}$ N., long $118^{\circ} 32^{\prime} \mathrm{W}$.

Land classification: Public domain, with some private lands.

Area: $38 \mathrm{~km}^{2}$ (cumulative).

Accessibility: $22 \mathrm{~km}$ north of State Highway 49, and $18 \mathrm{~km}$ north of Western Pacific

Railroad.

Remoteness: Easternmost outcrop is $64 \mathrm{~km}$ northwest of Winnemucca (population 3,587), and main outcrop is $27 \mathrm{~km}$ northeast of Sulphur.

Geologic setting: The pluton is composed of scattered exposures of Mesozoic (Cretaceous?) granodiorite and diorite and some syenite. The granitic intrusives

intrude the Permian or older Happy Creek Volcanics, composed of andesitic to basaltic lava flows, flow-breccias, and tuffs, the Cretaceous King Lear Formation, composed of conglomerate, siltstone, graywacke, and 1 imestone; and Permian-Triassic volcanic and sedimentary rocks. The pluton is overlain unconformably by basaltic and andesitic volcanic rocks of Tertiary age.

The structure consists of thrust faults and Tertiary high-angle normal faults.

Hydrologic setting: The pluton is primarily in the Black Rock Desert ground-water system. Runoff drains to Black Rock Desert and Desert Valley. The nearest discharge point is $10 \mathrm{~km}$ west, along the Quinn River. Ground water is used in the region for livestock and domestic purposes.

Aeromagnetic expression: A high-amplitude positive anomaly clearly is associated with the main masses of granitic rock. The areal extent of the inferred anomaly source is about the same as that of the area of outcrop.

Mining activity: Gold placer operation near pluton.

Comment: Mining activity near pluton. 
H-14. JUNGO HILLS

General location: Jungo Hills, southwest of Desert Valley.

Coordinates: lat $41^{\circ} 04^{\prime} \mathrm{N}$., long $118^{\circ} 22^{\prime} \mathrm{W}$.

Land classification: Public domain, with some private lands.

Area: $3 \mathrm{~km}^{2}$ (cumulative).

Accessibility: Southern outcrop is $13 \mathrm{~km}$ north of State Highway 49 and Western Pacific

Railroad.

Remoteness: Southern outcrop is $13 \mathrm{~km}$ north of Jungo. Eastern outcrop is $48 \mathrm{~km}$ west of Winnemucca (population 3,587).

Geologic setting: The pluton is composed of Mesozoic (Jurassic-Cretaceous) granodiorite and diorite, and intrudes the Permian or older Happy Creek Volcanics and PermianTriassic volcanic and sedimentary rocks; it is overlain in some areas by basaltic and andesitic volcanic rocks. The structure of the area consists of high-angle normal faults.

Hydrologic setting: The pluton is in the Quinn River ground-water system and the Desert Valley drainage basin. The nearest discharge occurs by evapotranspiration about $4 \mathrm{~km}$ east, where depth to water is approximately $9 \mathrm{~m}$. Ground water is used in the valley for livestock and domestic purposes. Aeromagnetic expression: The small granitic rock exposures occur at the western part of the summit of a regional, moderately high amplitude, positive anomaly which noses southwestward from the regional positive anomaly associated with the Slumbering Hills pluton of $\mathrm{H}-8$. The maximum areal extent of that part of the anomaly source associated with the steepest gradients is estimated to be $15 \mathrm{~km}^{2}$. 


\section{H-15. BLUE MOUNTAIN}

General location: Southwestern flank of Blue Mountain.

Coordinates: lat $40^{\circ} 59^{\prime} \mathrm{N}$., long $118^{\circ} 03^{\prime} \mathrm{W}$.

Land classification: Private lands, with some public domain.

Area: $3 \mathrm{~km}^{2}$.

Accessibility: $2 \mathrm{~km}$ north of State Highway 49 and $4 \mathrm{~km}$ north of Western Pacific Railroad.

Remoteness: $28 \mathrm{~km}$ west of Winnemucca (population 3,587).

Geologic setting: The pluton is composed of Jurassic-Cretaceous diorite and intrudes

phyllite, slate, and quartzite of Triassic-Jurassic age. The major

structure in the area is a thrust fault just east of the intrusive.

Hydrologic setting: The pluton is mainly in the Humboldt River Basin ground-water system.

Runoff drains to the Humboldt River and Desert Valley. The nearest

discharge point is $12 \mathrm{~km}$ southeast, near the Humboldt River. Water is

used for irrigation, livestock, and public supply in the valley.

Aeromagnetic expression: The exposure of granitic rocks occurs on the northeastern flank of a northwest-trending, moderately high amplitude, positive anomaly. The inferred plutonic rock source has a maximum areal extent estimated to be $10 \mathrm{~km}^{2}$. 
H-16. WINNEMUCCA MOUNTAIN

General location: Southeastern flank of Winnemucca Mountain.

Coordinates: lat $41^{\circ} 00^{\prime}$ N., long $117^{\circ} 44^{\prime}$ W.

Land classification: Private lands, with some public domain.

Area: $1 \mathrm{~km}^{2}$.

Accessibility: $2 \mathrm{~km}$ west of Interstate Highway 95, $2 \mathrm{~km}$ northwest of State Highway 49, and $4 \mathrm{~km}$ northwest of Western Pacific and Southern Pacific Railroads.

Remoteness: $3 \mathrm{~km}$ northwest of Winnemucca (population 3,587).

Geologic setting: The pluton is composed of Jurassic-Cretaceous diorite and intrudes the

Triassic Winnemucca Formation composed of shales, sandstone, 1 imestone, and quartzite. The structure of the area consists of high-angle normal and thrust faults.

Hydrologic setting: The pluton is in the Humboldt River Basin ground-water system and drainage basin. The nearest discharge point is $3 \mathrm{~km}$ southeast near Winnemucca. The water is used for irrigation, livestock, and public supply.

Aeromagnetic expression: The small exposure of granitic rocks occurs on the northeastern flank of a low-amplitude positive anomaly nose having an unknown source. The maximum areal extent of this buried unknown source is estimated to be $1-5 \mathrm{~km}^{2}$. 


\section{H-17. EDNA MOUNTAIN}

General location: Edna Mountain.

Coordinates: lat $40^{\circ} 49^{\prime} \mathrm{N} .$, , long $117^{\circ} 24^{\prime} \mathrm{N}$.

Land classification: Public domain, with some private lands.

Area: $5 \mathrm{~km}^{2}$ (cumulative).

Accessibility: Main outcrop is $8 \mathrm{~km}$ southwest of U.S. Highway 40 , and $12 \mathrm{~km}$ south of Southern Pacific Railroad.

Remoteness: Main outcrop is $12 \mathrm{~km}$ southeast of Golconda (population 200), and $29 \mathrm{~km}$ southeast of Winnemucca (population 3,587).

Geologic setting: The Edna Mountain pluton is composed of scattered exposures of granodiorite that intrude the following units: Pennsylvanian and Permian Pumpernickel Formation, composed of greenstone, argillite, and limestone and the Antler Peak Limestone; and the Permian Edna Mountain Formation, composed of sandstone and quartzite. The Paleozoic rocks have undergone thrusting in the area. Some of the granitic bodies have been intruded along the thrust plates. Tertiary high-angle normal faults offset the thrust plates.

Hydrologic setting: The pluton is in the Humboldt River Basin ground-water system. Runoff drains to Pumpernickel Valley and Rock Creek, both tributaries of the Humboldt River. The nearest discharge point is about $5 \mathrm{~km}$ southeast of the center of the pluton. The ground water is used for livestock and domestic purposes in the area.

Aeromagnetic expression: The main outcrop of granitic rocks clearly is associated with an oval, short-wavelength, high-amplitude, positive anomaly. The maximum areal extent of the buried source is estimated to be $5 \mathrm{~km}^{2}$. 


\section{H-18. BUFFALO MOUNTAIN}

General location: Southwestern part of the Buffalo Mountain.

Coordinates: lat $40^{\circ} 43^{\prime}$ N., long $117^{\circ} 21^{\prime}$ W. (central location).

Land classification: Public domain.

Area: $38 \mathrm{~km}^{2}$.

Accessibility: $14 \mathrm{~km}$ southwest of U.S. Highway 40 and the Southern Pacific Railroad.

Remoteness: $15 \mathrm{~km}$ southwest of Valmy (population 50), and $37 \mathrm{~km}$ southeast of Winnemucca

(population 3,587).

Geologic setting: The pluton is composed of Jurassic granodiorite and intrudes the Pennsylvanian-Permian Havallah Formation which consists of sandstone, shale, quartzite, and limestone; Pennsylvanian Pumpernickel Formation, composed of greenstone, argillite, and limestone; and Triassic Cane Spring and Augusta Mountain Formations, composed of limestones and dolomites. The pluton has been dated as $145 \pm 3$ m.y., $151 \pm 3$ m.y., and $160 \pm 3$ m.y.

(Silberman and McKee, 1971). The structure of the area consists of very minor high-angle normal faulting.

Hydrologic setting: The pluton is in the Humboldt River Basin ground-water system. Runoff drains to Pumpernickel and Buffalo Valleys Basins. The nearest discharge point is $9 \mathrm{~km}$ north. The water is used for livestock and domestic purposes.

Aeromagnetic expression: A high-amplitude, chevron-shaped, positive anomaly occurs at the site of the exposures of granitic rocks. The northeast-trending part of the anomaly conforms with the northeastern trend of the exposures, the anomaly source having an estimated subsurface areal extent of $10 \mathrm{~km}^{2}$. The northwest-trending part of the anomaly does not conform with visible geologic structure. This part may represent a continuation of the anomaly trend associated with the Gregg Canyon pluton of $\mathrm{H}-19$.

Selected reference: Silberman and McKee, 1971. 
General location: Eastern flank of the Sonoma Range at Gregg Canyon.

Coordinates: lat $40^{\circ} 43^{\prime} \mathrm{N}$., long $117^{\circ} 32^{\prime} \mathrm{W}$.

Land classification: Private lands and public domain.

Area: $13 \mathrm{~km}^{2}$ (cumulative).

Accessibility: Northernmost outcrop is $17 \mathrm{~km}$ southwest of U.S. Highway 40, and $18 \mathrm{~km}$ southeast of Southern Pacific Railroad.

Remoteness: Northernmost outcrop is $18 \mathrm{~km}$ southwest of Golconda (population 200), and $23 \mathrm{~km}$ southeast of Winnemucca (population 3,587).

Geologic setting: The pluton is composed of Cretaceous granodiorite and intrudes the Lower Cambrian(?) Osgood Mountain Quartzite and Middle and Upper Cambrian Preble Formation; the Ordovician Valmy Formation, composed of shale, quartzite, and greenstone; the Pennsylvanian-Permian Havallah Formation, composed of sandstone, shale, quartzite, and limestone; and the Pennsylvanian Pumpernickel Formation, composed of greenstone, argillite, and limestone. The pluton has been dated as $104 \pm 2$ m.y. (Silberman and McKee, 1971). The structure consists predominantly of thrust faults.

Hydrologic setting: The pluton is in the Humboldt River Basin ground-water system and runoff drains to the Pumpernickel Valley Basin. The nearest discharge point is $12 \mathrm{~km}$ northeast, and the water is used for livestock and domestic purposes.

Aeromagnetic expression: The granitic rock exposures occur on the flanks of a northwesttrending high-amplitude positive anomaly presumably assuciated with buried plutonic rocks. The maximum areal extent of the inferred source is about $15 \mathrm{~km}^{2}$. It is possible that the northwest-trending part of the positive anomaly associated with the Buffalo Mountain pluton of $\mathrm{H}-18$ represents a subsurface continuation of the trend of these rocks.

Selected reference: Silberman and McKee, 1971. 


\section{PERSHING COUNTY}

\section{GEOLOGY}

Pershing County (fig. 17) is located in the northwestern part of the State. The county is characterized by north-northeast-trending mountain ranges separated by narrow valleys.

The county consists of sedimentary, metamorphic, and igneous rocks of Cambrian to Holocene age.

The Cambrian, Ordovician, Mississippian, Pennsvlvanian, and Permian rocks are found in the eastern part of the county. They consist predominantly of clastic sedimentary, some carbonate, and minor volcanic rocks.

The Triassic-Jurassic rocks are found throughout the county and consist of clastic sedimentary rocks and some carbonate and volcanic rocks. Other rocks of Triassic-Jurassic age include granodiorite, leucogranite, and quartz monzonite intrusives.

The Cretaceous rocks are represented by granodiorite and quartz monzonite intrusives. No sedimentary rocks of Cretaceous age are present in the county.

The Tertiary rocks in the county consist of tuffs, lava flows, and breccias of rhyolitic, andesitic, and basaltic composition, and sedimentary rocks. Basaltic flows of TertiaryQuaternary age are also present.

The area has undergone four major periods of deformation that caused folding, thrust faulting, and high-angle normal faulting (Johnson, 1977). The periods of deformation are: (1) Antler orogeny of Late Devonian and Early Mississippian age, (2) Sonoma orogeny of Early Triassic age, (3) Nevadan orogeny of Jurassic and Cretaceous age, and (4) Basin and Range deformation of Tertiary-Quaternary age.

The county lies within the northern extension of the Nevada seismic zone. An earthquake occurred in 1915 in the Pleasant Valley area, west side of the Tobin Range, eastern part of the county, along the Churchill arc (pl. 4). The Churchill arc is a north-trending arcuate linear zone located mostly in Churchill County but extending northward into the southeastern part of Pershing County.

The geologic information was abstracted and summarized from the following: Johnson, 1977; and Tatlock, 1969.

\section{HYDROLOGY}

The Humboldt River flows south-southwest through central Pershing County and drains about one-fourth of the county. Northwestern Pershing County drains to the southwestern Black Rock Desert lowland area, and a small part of southwestern Pershing County drains to Winnemucca (dry) Lake. A part of Hualapai Flat is in extreme northwest Pershing County; the flat is a topographically closed drainage basin. The central southwestern part of the county drains to Granite Springs and Kumiva Valleys, which are each topographically closed. Other topographically closed drainage basins in and partly in Pershing County are: Buena Vista Valley, Packard Flat (north of Carson Sink), and Buffalo Valley. Pleasant and Jersey Valleys are tributaries to Dixie Valley. 


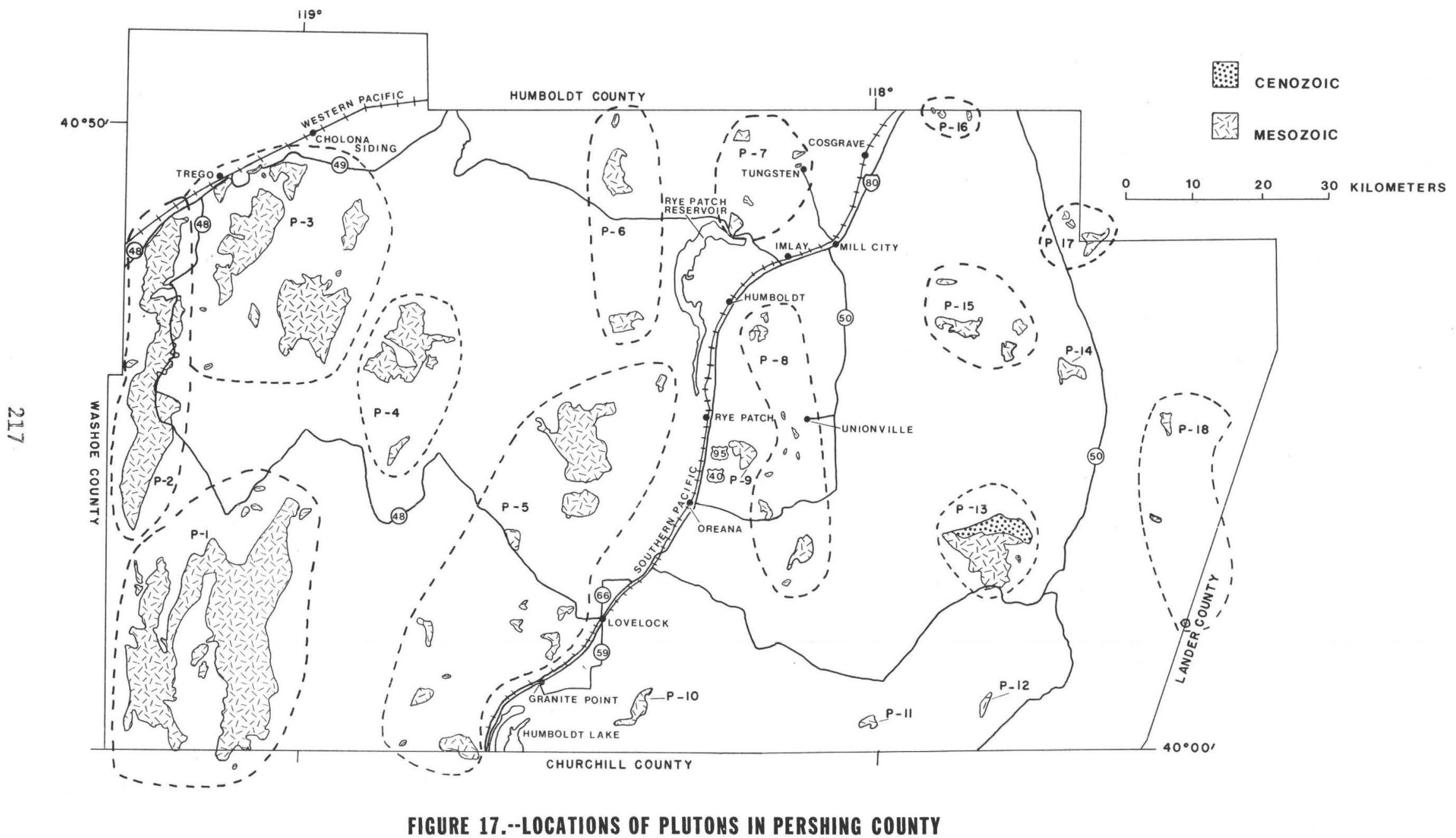


The significant sources of recharge and runoff in Pershing County are Tobin, Sonoma, East, and Humboldt Ranges. Minor sources of recharge and runoff include northern Shawave Mountains, Kumiva Peak in the Selenite Range, northern Seven Troughs Range and northern Stillwater Range.

Ground water migrates parallel to drainage in the Humboldt River Basin system; Grass Valley aquifers feed some water into the Humboldt ground-water system. The southern part of the Black Rock Desert ground-water system underlies northwestern Pershing County, and Hualapai Flat feeds water into this system. The Granite Springs Valley closed ground-water system, including Kumiva Valley, underlies southwest-central Pershing County. Buena Vista Valley ground-water system is also closed and underlies its centripetal drainage basin. Ground water moves southward from Packard Flat (south-central Pershing County) into the Carson River Basin ground-water system. Ground water moves southward from Pleasant and Jersey Valleys into the Dixie Valley system, mostly south of the southeast corner of the county. The Buffalo Valley area of northeastern Pershing County features movement eastward, thence northward into the Humboldt River Basin system. Desert Valley, at the north-central edge of Pershing County, leaks water northward into the Quinn River ground-water system.

The hydrology of Pershing County was taken from the following references:

Cohen, 1964; Cohen and Everett, 1963; Eakin, 1962d; Everett and Rush, 1965; Harri11, 1970; Loeltz and Phoenix, 1955; and Sinclair, 1963a. 


\section{PLUTONS}

\section{P-1. NIGHTINGALE-SHAWAVE}

General location: Nightingale and Shawave Mountains, southwestern part of the county. Coordinates: Main outcrop at 1 at $40^{\circ} 10^{\prime} \mathrm{N}$, , long $119^{\circ} 07^{\prime} \mathrm{W}$.

Land classification: Public domain, with some private lands.

Area: $402 \mathrm{~km}^{2}$ (cumulative).

Accessibility: Westernmost exposure is $7 \mathrm{~km}$ east of State Highway 34 (Washoe County). The northern part of the major exposure is $4 \mathrm{~km}$ south of State Highway 48.

Remoteness: Easternmost exposure is $48 \mathrm{~km}$ west of Lovelock (population 1,571).

Geologic setting: The Nightingale-Shawave pluton consists of several scattered exposures of cretaceous granodiorite. The granodiorite body intrudes shale, mudstone, siltstone, and carbonates of Triassic-Jurassic age. In some areas, the Triassic-Jurassic sedimentary rocks are present as roof pendants. The pluton is intruded by mafic and felsite dikes and is overlain unconformably by Tertiary volcanic and sedimentary rocks that are shown undivided on the geologic map (Tatlock, 1969). Basalt flows of Tertiary age are also present overlying the pluton. Quaternary alluvium is in contact with the pluton along its flanks. Part of the pluton has been dated as $87.2 \pm 3.7$ and $90.2 \pm 6.1 \mathrm{m.y}$. (Smith and others, 1971).

The Nightingale-Shawave Mountains form an uplifted fault block, with highangle normal faults along the flanks of the mountains. The predominant structure is north-northeast-trending high-angle normal faults that bound and cut the pluton.

The southern part of the mountains is a very active seismic area and is within the Nevada seismic zone.

Hydrologic setting: The pluton is in the Granite Springs Valley and Winnemucca Lake groundwater systems. Runoff drains mainly to Granite Springs Valley and Sage Hen Wash, a tributary. The nearest discharge occurs $17 \mathrm{~km}$ east, where the water is used for livestock and domestic purposes.

Aeromagnetic expression: The granitic rock terrane is clearly associated with a series of positive anomalies. A northwestward extension of these anomalies at the northern margin of the exposures may be underlain by similar granitic rocks having a maximum areal extent of about $50 \mathrm{~km}^{2}$.

Comment: Seismically active area within the Nevada seismic zone.

Selected reference: Tatlock, 1969. 


\section{P-2. SELENITE}

General location: Selenite Range, western part of the county.

Coordinates: Main outcrop at lat $40^{\circ} 30^{\prime} \mathrm{N}$., long $119^{\circ} 15^{\prime} \mathrm{W}$.

Land classification: Public domain, with some private lands.

Area: $193 \mathrm{~km}^{2}$ (cumulative).

Accessibility: $6 \mathrm{~km}$ east of State Highway 34 and $0.5 \mathrm{~km}$ south of the Western Pacific Railroad

tracks. State Highway 48 intersects the central part of the exposed pluton.

Remoteness: $8 \mathrm{~km}$ southwest of Trego.

Geologic setting: The Selenite Range pluton is composed of cretaceous granodiorite and intrudes metamorphosed volcanic rocks and sedimentary rocks of Permian(?) age. Also intruded are shale, mudstone, siltstone, sandstone, and carbonates of Triassic-Jurassic age. The granitic body is overlain unconformably by volcanic and sedimentary rocks of Tertiary age and by Tertiary basalt and rhyolite lava flows. Quaternary alluvium flanks the pluton. The pluton has been dated as $91.3 \pm 3.8$ and $93.9 \pm 6.0$ m.y. (Smith and others, 1971) and is probably related to or part of the NightingaleShawave pluton.

The Selenite Range is an uplifted fault block of Tertiary age bounded by north-northeast-trending high-angle normal faults.

Hydrologic setting: The pluton is primarily in the Black Rock Desert and Granite Springs Valley ground-water systems. Runoff drains to Black Rock Desert, Kumiva Valley and Winnemucca Lake. The nearest discharge is $10 \mathrm{~km}$ northwest, where the water is used for livestock, domestic, and industrial purposes.

Aeromagnetic expression: The granitic rocks clearly are associated with a north-trending belt of positive anomalies. The areal extent of the anomaly sources is about the same as that of the exposed rocks.

Mining activity: Gypsum mining on the western flank, central part of the Selenite Range. Comment: Area is within the Nevada seismic zone and near active mining.

Selected reference: Smith, McKee, Tatlock, and Marvin, 1971. 
General location: The Lava Beds and Pahsupp Mountain area.

Coordinates: Main outcrop at lat $40^{\circ} 35^{\prime} \mathrm{N}$., long $119^{\circ} 00^{\prime} \mathrm{W}$.

Land classification: Public domain.

Area: $198 \mathrm{~km}^{2}$ (cumulative).

Accessibility: $0.5 \mathrm{~km}$ south of Western Pacific Railroad, and northern exposure intersected by State Highway 49.

Remoteness: $0.5 \mathrm{~km}$ south of Trego and $5 \mathrm{~km}$ southwest of Cholona Siding.

Geologic setting: The Heineke pluton consists of scatteredexposures of Cretaceous granodiorite and intrudes metamorphosed volcanic and sedimentary rocks of Permian(?) age. The Permian rocks also occur as roof pendants. Also intruded are shale, mudstone, siltstone, sandstone, and carbonates of Triassic-Jurassic age. The pluton is overlain by Tertiary sedimentary rocks and by Tertiary-Quaternary basalt flows. Quaternary alluvium is found in contact with the granitic mass along its flanks. The pluton is probably part of the Selenite Range and Nightingale-Shawave Mountains plutons.

The structure of the area consists of north-northeast-trending high-angle normal faults that bound the pluton.

Hydrologic setting: The pluton is in the Black Rock Desert and Granite Springs Valley groundwater systems. Runoff flows mainly to Black Rock Desert and Kumiva Valleys. The nearest discharge is $16 \mathrm{~km}$ northwest, where the water is used primarily for livestock and domestic purposes.

Aeromagnetic expression: The northern masses of granitic rock clearly are associated with a regional high-amplitude positive anomaly that appears to be connected with the positive anomaly belt associated with the Selenite pluton of P-2. The buried source, inferred to be granitic rocks, has a maximum areal extent estimated to be $75-100 \mathrm{~km}^{2}$. The southern mass of granitic rocks occurs within a broad magnetic depression.

Comment: Area within the Nevada seismic zone. 


\section{P-4. SEVEN TROUGHS}

General location: Seven Troughs Range, western half of the county.

Coordinates: Main outcrop at lat $40^{\circ} 33^{\prime}$ N., Tong $118^{\circ} 48^{\prime} \mathrm{W}$.

Land classification: Public domain, with some patented mining claims.

Area: $67 \mathrm{~km}^{2}$ (cumulative).

Accessibility: Central exposure is $11 \mathrm{~km}$ northwest of State Highway 48.

Remoteness: $45 \mathrm{~km}$ northwest of Lovelock (population 1,571).

Geologic setting: The Seven Troughs pluton is composed of scattered exposures predominantly of Cretaceous granodiorite, with some leucogranite. The pluton intrudes shale, mudstone, siltstone, sandstone, and carbonates of Triassic-Jurassic age. The granitic mass is overlain unconformably by Tertiary volcanic and sedimentary rocks. Other rocks overlying the pluton include rhyolites of Tertiary age and basalt flows of Tertiary-Quaternary age. Quaternary alluvium is found in contact with the pluton in some areas.

The structure in the area includes high-angle normal faults that trend northwest and northeast. The northwest-trending faults cut the pluton.

Hydrologic setting: The pluton is in the Granite Springs Valley and Black Rock Desert groundwater systems. Runoff drains to Black Rock Desert and Granite Springs Valley. The nearest discharge point is $24 \mathrm{~km}$ southwest and the water is used for livestock and domestic purposes.

Aeromagnetic expression: The isolated granitic rock exposures are generally associated with high-amplitude positive anomalies. The areal extent of the inferred buried granitic rocks may be as great as $200-300 \mathrm{~km}^{2}$.

Mining activity: Gold and silver mining along east flank of mountain range.

Comment: Area within the Nevada seismic zone, near active mining. 


\section{P-5. TRINITY RANGE}

General location: Trinity Range, central and south-central parts of the county.

Coordinates: Main outcrop at lat 40 $24^{\prime}$ N., long $118^{\circ} 30^{\prime} \mathrm{W}$.

Land classification: Public domain, private lands, with some Bureau of Reclamation withdrawals.

Area: $150 \mathrm{~km}^{2}$ (cumulative).

Accessibility: Main outcrop is $13 \mathrm{~km}$ west of U.S. Highway 95 and 40 and the Southern Pacific

Railroad, and $12 \mathrm{~km}$ southeast of State Highway 48.

Remoteness: Main outcrop is $20 \mathrm{~km}$ northwest of Lovelock (population 1,571).

Geologic setting: The Trinity Range pluton consists of numerous scattered exposures of .

Cretaceous granodiorite that intrude shale, mudstone, sandstone, and carbonates of Triassic-Jurassic age. Roof pendants of the TriassicJurassic rocks are present in some areas. Tertiary volcanic rocks that overlie the pluton include tuffs, lava flows, and breccias of rhyolitic, andesitic, and basaltic composition. Tertiary-Quaternary basalt flows also overlie the pluton unconformably. The northernmost exposure has been dated as $93.7 \pm 3.9$ and $89.6 \pm 5.9$ m.y. (Smith and others, 1971).

The predominant structure includes north-northeast-, and northwest-trending high-angle normal faults of Basin and Range age.

Hydrologic setting: The pluton is in the Humboldt River Basin and Granite Springs Valley ground-water systems. Runoff flows to Granite Springs Valley and to the Humboldt River. The nearest discharge point is $9 \mathrm{~km}$ to the southeast, and water is used in the river valley for irrigation and public supply.

Aeromagnetic expression: The granitic rock masses are associated with several high-amplitude positive anomalies. Buried source rocks of these anomalies are inferred to have an areal extent of about $150 \mathrm{~km}^{2}$.

Mining activity: Gold, diatomite, and lightweight aggregate and perlite mining along the Trinity Range. Pluton is located $1 \mathrm{~km}$ west of Humboldt Lake.

Comment: Area within the Nevada seismic zone.

Selected reference: Smith, McKee, Tatlock, and Marvin, 1971. 


\section{P-6. HAYSTACK BUTTE}

General location: Antelope Range and Majuba Mountain area.

Coordinates: Main outcrop at lat $40^{\circ} 46^{\prime} \mathrm{N}$., long $118^{\circ} 26^{\prime} \mathrm{W}$.

Land classification: Public domain and private lands.

Area: $26 \mathrm{~km}^{2}$ (cumulative).

Accessibility: Main outcrop is $22 \mathrm{~km}$ northwest of U.S. Highway 95 and $40,21 \mathrm{~km}$ northwest of Southern Pacific Railroad, and 3 km north of State Highway 49.

Remoteness: Main outcrop is $26 \mathrm{~km}$ west of Tungsten.

Geologic setting: Several exposures of Cretaceous granodiorite occur in the Antelope Range and Majuba Mountain area. The pluton intrudes shale, mudstone, siltstone, sandstone, and carbonates of Triassic-Jurassic age. Other rocks in the vicinity of the pluton include Tertiary volcanic and sedimentary rocks, undivided. Tertiary basalt and rhyolite lava flows are also present. No exposed structure was mapped in the vicinity of the granitic exposure. The largest exposed outcrop has been dated as $92.0 \pm 3.9$ and $95.2 \pm 6.3$ m.y. (Smith and others, 1971).

Hydrologic setting: The pluton is principally in the Humboldt River Basin ground-water system. Runoff flows to the Humboldt River and Desert Valley drainage basins. The nearest point of discharge to the center of the pluton is $10 \mathrm{~km}$ eastward, where the water is used mainly for irrigation and public supply.

Aeromagnetic expression: The northern mass of granitic rocks is associated with a highamplitude positive anomaly. The central mass has no pronounced magnetic signature. The southern mass is associated with a lowamplitude positive anomaly. The buried source of the anomaly over the northern mass may be about $25 \mathrm{~km}^{2}$.

Mining activity: Gold placer mining in southern end of Majuba Mountain near pluton.

Comment: The pluton is located near mining activity, within the Nevada seismic zone, and

$5 \mathrm{~km}$ northwest of the Rye Patch Reservoir.

Selected reference: Smith, McKee, Tatlock, and Marvin, 1971. 


\section{P-7. EUGENE MOUNTAINS}

General 1ocation: Eugene Mountains, north-central part of the county near Humboldt County line.

Coordinates: Main outcrop at lat $40^{\circ} 42^{\prime}$ N., long $118^{\circ} 14^{\prime} \mathrm{W}$.

Land classification: Public domain and private land.

Area: $10 \mathrm{~km}^{2}$ (cumulative).

Accessibility: Southwesternmost outcrop is $6 \mathrm{~km}$ northwest of Southern Pacific Railroad and

$7 \mathrm{~km}$ northwest of U.S. Highway 95 and 40 . State Highway 49 intersects main outcrop.

Remoteness: Main outcrop is $8 \mathrm{~km}$ northwest of Imlay (population 170).

Geologic setting: Several scattered exposures of Cretaceous granodiorite occur in the Eugene Mountains. The granodiorite bodies intrude shale, mudstone, siltstone, sandstone, and carbonates of Triassic-Jurassic age. The pluton has been dated as 90.0 2.7 m.y. (Krueger and Schilling, 1971). Tingley (1975) has reported ages of a series of granodiorite intrusives near Tungsten ranging from 66.5 to 88.9 m.y.

The predominant structures are high-angle normal faults. The normal faults trend north-northeast.

Hydrologic setting: The pluton is primarily in the Humboldt River Basin ground-water system. Runoff drains to the Humboldt River and Desert Valley. The nearest discharge point is $9 \mathrm{~km}$ southward in the Humboldt River valley, where the water is used mainly for irrigation and public supply.

Aeromagnetic expression: The isolated exposures of granitic rocks occur on the flanks or near the summits of two high-amplitude positive anomalies having buried source rocks and a cumulative areal extent of about $35 \mathrm{~km}^{2}$.

Mining activity: Tungsten mining in central and southwestern part of the Eugene Mountains near the pluton.

Comment: Area within the Nevada seismic zone, and less than $1 \mathrm{~km}$ northeast of the Rye Patch Reservoir.

Selected reference: Krueger and Schilling, 1971; Tingley, 1975. 


\section{P-8. HUMBOLDT RANGE}

General location: Scattered outcrops throughout the Humboldt Range.

Coordinates: Main outcrop at lat $40^{\circ} 16^{\prime} \mathrm{N}$., long $118^{\circ} 08^{\prime} \mathrm{W}$.

Land classification: Public domain, private lands, with some patented mining claims.

Area: $20 \mathrm{~km}^{2}$ (cumulative).

Accessibility: Southern exposures, $18 \mathrm{~km}$ east of U.S. Highway 95 and 40 and $19 \mathrm{~km}$ east of the Southern Pacific Railroad; northern exposures, $5 \mathrm{~km}$ east of U.S. Highway 95 and 40 and $6 \mathrm{~km}$ east of the Southern Pacific Railroad.

Remoteness: Southern exposures, $28 \mathrm{~km}$ northeast of Lovelock (population 1,571); northern exposures, $8 \mathrm{~km}$ southwest of Imlay (population 170).

Geologic setting: The Humboldt Range pluton consists of several scattered exposures, composed of Triassic leucogranite, along the Humboldt Range. The granitic bodies intrude the Triassic Koipato Group, which includes andesite flows, rhyolite tuffs, and lava flows. Also intruded are limestone, minor amounts of dolomite, shale, and sandstone, and some conglomerates of Triassic age.

The Humboldt Range is an uplifted fault block of Basin and Range age. The predominant structures are north-northeast- and northwest-trending high-angle normal faults.

Thrust faults are present along the range mostly along its western flank, in the northern part. One of the granitic bodies occurring in the northern part of the range has been displaced by a thrust fault.

Hydrologic setting: The pluton is predominantly in the Humboldt River Basin and Buena Vista valley ground-water systems; the southernmost part of the pluton is probably in the Carson River Basin ground-water system. Runoff drains to the Humboldt River, Packard Flat, and Buena Vista Valley. The most significant discharge occurs in the Humboldt River $13 \mathrm{~km}$ west of the center of the exposures, where the water is used for irrigation and public supply.

Aeromagnetic expression: The isolated exposures of granitic rocks occur in a regional north-trending belt of high-amplitude positive anomalies. The cumulative areal extent of sources corresponding to these anomalies may be as great as $250-300 \mathrm{~km}^{2}$.

Mining activity: Gold mining in southwestern part of the Humboldt Range.

Comment: Area within the Nevada seismic zone. 
General location: West flank of the Humboldt Range near Rocky Canyon.

Coordinates: Lat $40^{\circ} 24^{\prime} \mathrm{N}$., long $118^{\circ} 13^{\prime} \mathrm{W}$.

Land classification: Public domain and private lands.

Area: $8 \mathrm{~km}^{2}$.

Accessibility: $3 \mathrm{~km}$ east of the Southern Pacific Railroad and U.S. Highway 95 and 40 and

$8 \mathrm{~km}$ southeast of Rye Patch Reservoir.

Remoteness: $4 \mathrm{~km}$ southeast of Rye Patch.

Geologic setting: A single exposure of Cretaceous granodiorite occurs on the west flank of the central part of the Humboldt Range. The granodiorite intrudes the Triassic Koipato Group that is made up of andesite flows, rhyolite tuff, lava flows, and clastic rocks. Limestone and minor amounts of dolomite, shale, and sandstone of Triassic age are also intruded by the granodiorite body.

The Humboldt Range is an uplift fault block, bounded by high-angle normal faults. The pluton occurs near some of these faults.

Hydrologic setting: The pluton is in the Humboldt River Basin ground-water system and Humboldt River drainage basin. The nearest discharge is $4 \mathrm{~km}$ west of the center of outcrop, where the water is used primarily for public supply and irrigation.

Aeromagnetic expression: The pluton occurs at the northern flank of a positive anomaly, which appears to be connected with anomalies associated with the Humboldt Range pluton of P-8.

Comment: Area witr in the Nevada seismic zone. 
P-10. WEST HUMBOLDT

General location: West flank southern part of the West Humboldt Range.

Coordinates: Lat $40^{\circ} 04^{\prime} \mathrm{N}$., long $118^{\circ} 25^{\prime} \mathrm{W}$.

Land classification: Public domain and private lands.

Area: $9 \mathrm{~km}^{2}$.

Accessibility: $6 \mathrm{~km}$ southeast of State Highway 59.

Remoteness: $14 \mathrm{~km}$ southeast of Granite Point, $12 \mathrm{~km}$ southeast of Lovelock (population 1,571).

Geologic setting: The southern West Humboldt Range pluton is a single exposure of granodiorite.

The granodiorite intrudes shale, mudstone, siltstone, sandstone, and carbonates of Triassic-Jurassic age. The exposed pluton has been dated as $104 \pm 4$ m.y. (Smith and others, 1971).

Thrust faults are the predominant structure in the vicinity of the intrusive. No high-angle normal faults have been mapped.

Hydrologic setting: The outcrop is in the Humboldt River Basin ground-water system and drainage basin. The center of the outcrop is $2 \mathrm{~km}$ east of the discharge area, and the southern part of the exposure is in the discharge area. Water is used in the valley mainly for irrigation and public supply.

Aeromagnetic expression: A low-amplitude positive anomaly flexure is associated in part with the plutonic rock exposure. This flexure is continuous with one of the positive anomalies associated with the Trinity Range pluton of $\mathrm{P}-5$.

Comment: Area within the Nevada seismic zone.

Selected reference: Smith, McKee, Tatlock, and Marvin, 1971. 


\section{P-11. NEW YORK CANYON}

General location: West flank of the Stillwater Range at New York Canyon.

Coordinates: Lat $40^{\circ} 03^{\prime} \mathrm{N}$., long $118^{\circ} 01^{\prime} \mathrm{W}$.

Land classification: Public domain.

Area: $4 \mathrm{~km}^{2}$.

Accessibility: $38 \mathrm{~km}$ southeast of U.S. Highway 95 and 40 and Southern Pacific Railroad, and

$5 \mathrm{~km}$ south of an improved surface road.

Remoteness: $40 \mathrm{~km}$ southeast of Lovelock (population 1,571).

Geologic setting: The pluton is composed of Cretaceous quartz monzonite and intrudes shale, mudstone, siltstone, sandstone, and carbonates of Triassic-Jurassic age. The pluton has been dated as $69 \pm 3$ m.y. (Speed and Armstrong, 1971). The structure of the area consists of high-angle normal and thrust faults.

Hydrologic setting: The pluton is in the Buena Vista Valley ground-water system and drainage basin, both closed hydrologically. The nearest discharge is $7 \mathrm{~km}$ north, where water is used for livestock and domestic purposes.

Aeromagnetic expression: No distinctive anomaly is associated with the pluton.

Mining activity: Clay mining operation in northwestern part of the Stillwater Range.

Comment: Area within the Nevada seismic zone.

Selected reference: Speed and Armstrong, 1971. 


\section{P-12. STILLWATER}

General location: East flank Stillwater Range near Gamble Basin.

Coordinates: Lat $40^{\circ} 04^{\prime} \mathrm{N}$., long $117^{\circ} 49^{\prime} \mathrm{W}$.

Land classification: Public domain.

Area: $2 \mathrm{~km}^{2}$.

Accessibility: $52 \mathrm{~km}$ southeast of U.S. Highway 95 and 40 and Southern Pacific Railroad;

$4 \mathrm{~km}$ west of an improved surface road.

Remoteness: $57 \mathrm{~km}$ southeast of Lovelock (population 1,571).

Geologic setting: A single exposure of Triassic leucogranite occurs on the east flank, northern part of the Stillwater Range. The leucogranite intrudes the Triassic Koipato Group composed of andesite flows, rhyolite tuffs, and lava flows.

The exposure is bounded on the east by a northeast-trending high-angle normal fault that brings the leucogranite body in contact with Quaternary alluvium. The major structures in the area are high-angle normal faults, but thrust faults are present approximately $5 \mathrm{~km}$ southwest and $3 \mathrm{~km}$ west of the intrusive.

Hydrologic setting: The pluton is in the Dixie Valley ground-water system and drainage basin, both closed hydrologically. The nearest discharge occurs $29 \mathrm{~km}$ southwest out of the county, and water is used in Dixie Valley for livestock and domestic purposes.

Aeromagnetic expression: The elongate granitic rock exposure occurs at the eastern flank of a northeast-trending high-amplitude positive anomaly having a buried source and a maximum areal extent of about $50 \mathrm{~km}^{2}$.

Comment: Area within the Nevada seismic zone. 


\section{P-13. GRANITE MOUNTAIN STOCK}

General location: Southern part of the East Range at Granite Mountain.

Coordinates: Lat $40^{\circ} 17^{\prime}$ N., long $117^{\circ} 49^{\prime}$ W.

Land classification: Predominantly public domain, with some private lands, patented mining claims, and Bureau of Reclamation withdrawals.

Area: $78 \mathrm{~km}^{2}$ (cumulative).

Accessibility: $37 \mathrm{~km}$ east of U.S. Highway 95 and 40 and Southern Pacific Railroad, and $5 \mathrm{~km}$ west of an improved surface road. A major improved surface road also intersects the pluton.

Remoteness: $55 \mathrm{~km}$ northeast of Lovelock (population 1,571).

Geologic setting: A multiple intrusive which herein is considered one pluton. The pluton is composed of Triassic leucogranite and Tertiary quartz monzonite. The younger quartz monzonite intrudes the following: older leucogranite; and Pennsylvanian to Permian Havallah and Pumpernickel Formations, composed of chert, argillite, shale, greenstone, and minor amounts of siltstone, sandstone, conglomerate, and limestone; and the Triassic Koipato Group, consisting of andesitic flows, rhyolitic tuffs and flows, and clastic rocks. The leucogranite intrudes the Havallah and Pumpernickel Formations, Koipato Group, and shale, mudstone, sandstone, and carbonates of Triassic-Jurassic age. Tertiary volcanic rocks overlie the leucogranite unconformably. The East Range is an uplifted fault block of Basin and Range age. The structure consists of north-northeasttrending high-angle normal faults. Thrust faults are also present along the mountain range but do not appear to affect the pluton.

The pluton is within the Nevada seismic zone where an earthquake occurred on October 2, 1915, in the Pleasant Valley area, east of the pluton. The large earthquake resulted in surface breakage along a fault at the base of the Tobin Range.

Hydrologic setting: The pluton is in the Buena Vista Valley and Dixie Valley ground-water systems. Runoff drains to Buena Vista Valley and to Dixie Valley via the Pleasant Valley tributary. The nearest discharge is $9 \mathrm{~km}$ west, where water is used for livestock and domestic purposes.

Aeromagnetic expression: An elliptical, west-trending, high-amplitude, positive anomaly is centered over the composite terrane of exposed granitic rocks. The areal extent of the inferred anomaly source is about the same as that of the exposed rocks.

Comment: The pluton is located in the Nevada seismic zone and near the site of a 1915 earthquake. 
General location: East flank of the East Range, near Home Creek.

Coordinates: Lat $40^{\circ} 31^{\prime} \mathrm{N}$., long $117^{\circ} 40^{\prime} \mathrm{W}$.

Land classification: Public domain.

Area: $6 \mathrm{~km}^{2}$.

Accessibility: $32 \mathrm{~km}$ east of State Highway 50 and $2 \mathrm{~km}$ west of an improved surface road.

Remoteness: $76 \mathrm{~km}$ northeast of Lovelock (population 1,571) and $37 \mathrm{~km}$ southeast of Mil1 City (population 10).

Geologic setting: A single exposure of Triassic leucogranite occurs in the east flank of the East Range and intrudes the Pencisylvanian to Permian Havallah and Pumpernickel Formations, compused of chert, argillite, shale, greenstone, and minor amounts of siltstone, sandstone, conglomerate, and limestone. The leucogranite is overlain unconformably by Tertiary volcanic rocks. The area has been uplifted by high-angle normal faults. Thrust faults are common northwest of the leucogranite.

Hydrologic setting: The pluton is in the Humboldt River Basin ground-water system and drainage basin (Grass Valley tributary). The nearest discharge is $24 \mathrm{~km}$ north, where water is used mainly for livestock, domestic, and irrigation purposes.

Aeromagnetic expression: No distinctive anomaly is associated with the granitic rock exposure, presumably because of its silicic composition.

Comment: Area within the Nevada seismic zone. 
General location: Central part of the East Humboldt Range at Lee Peak.

Coordinates: Main outcrop at 1 at $40^{\circ} 35^{\prime} \mathrm{N}$., long $117^{\circ} 52^{\prime} \mathrm{W}$.

Land classification: Public domain, with some private lands.

Area: $17 \mathrm{~km}^{2}$ (cumulative).

Accessibility: Easternmost part of the main outcrop is $13 \mathrm{~km}$ east of State Highway $50,18 \mathrm{~km}$ southeast of U.S. Highway 95 and 40 , and $15 \mathrm{~km}$ west of an improved surface road.

Remoteness: $18 \mathrm{~km}$ southeast of Mill City (population 10) and $65 \mathrm{~km}$ northeast of Lovelock (population 1,571).

Geologic setting: The Lee Peak pluton consists of scattered exposures of quartz monzonite.

The quartz monzonite intrudes the following: Cambrian Harmony Formation, composed of feldspathic and arkosic sandstone and minor amounts of shale, limestone, and chert; siliceous and volcanic rocks of Ordovician age; Pennsylvanian to Permian Havallah and Pumpernickel Formations, composed of chert, argillite, shale, greenstone, and minor amounts of siltstone, sandstone, conglomerate and limestone; Triassic limestone, shale, and sandstone; and Triassic-Jurassic shale, mudstone, siltstone, sandstone, and carbonates. The eastern parts of the pluton are flanked in some areas by Quaternary alluvium. The quartz monzonite has been dated as $131 \pm 3 \mathrm{~m} . y$. and $149 \pm 3 \mathrm{~m} . \mathrm{y}$. (Silberman and McKee, 1971).

Thrust faults are very common in the vicinity of the pluton but do not appear to affect it. High-angle normal faults that trend north-northeast are also present, but are not as common as thrust faults.

Hydrologic setting: The pluton is in the Humboldt River Basin ground-water system and runoff drains to the river via the Grass Valley tributary. The nearest discharge area is $15 \mathrm{~km}$ northward, where water is used primarily for livestock, domestic, and irrigation purposes.

Aeromagnetic expression: The masses of exposed plutonic rocks occur on the crest or eastern flank of a north-northwest-trending high-amplitude positive anomaly. This anomaly extends about $15 \mathrm{~km}$ north of the exposures, reflecting a buried source having a maximum areal extent of about $50 \mathrm{~km}^{2}$.

Comment: Area within the Nevada seismic zone. Selected reference: Silberman and McKee, 1971. 


\section{P-16. DUN GLEN PEAK}

General location: Northern part of the East Range, near Dun Glen Peak.

Coordinates: Main outcrop at lat $40^{\circ} 51^{\prime} \mathrm{N}$, long $117^{\circ} 53^{\prime} \mathrm{W}$.

Land classification: Public domain and private lands.

Area: $1 \mathrm{~km}^{2}$ (cumulative).

Accessibility: $5 \mathrm{~km}$ east of Interstate Highway 80 and $6 \mathrm{~km}$ east of Southern Pacific Railroad.

Remoteness: $17 \mathrm{~km}$ southwest of Winnemucca (Humboldt County, population 3,587) and $13 \mathrm{~km}$ east of Cosgrove.

Geologic setting: The pluton is composed of Cretaceous granite and intrudes Triassic-Jurassic shale, mudstone, siltstone, sandstone, and carbonates. The structure of the area consists of high-angle normal faults and some thrust faults.

Hydrologic setting: The pluton is in the Humboldt River Basin ground-water system and drainage flows to the river via the Grass Valley tributary. The nearest discharge occurs $6 \mathrm{~km}$ eastward, where water is used mainly for livestock, domestic, and irrigation purposes.

Aeromagnetic expression: The small granitic rock exposure occurs at the northern extremity of the elongate positive anomaly that extends northward from the Lee Peak pluton of P-15.

Mining activity: Gold hard rock and gold placer mining activity in the northern part of the East Range.

Comment: The pluton is located within the Nevada seismic zone and near mining activity. 
General location: West flank of the Sonoma Range near Grand Trunk Canyon.

Coordinates: Main outcrop at lat $40^{\circ} 41^{\prime} \mathrm{N}$., long $117^{\circ} 38^{\prime} \mathrm{W}$.

Land classification: Public domain and private lands.

Area: $10 \mathrm{~km}^{2}$ (cumulative).

Accessibility: Main outcrop is $4 \mathrm{~km}$ east of an improved surface road and $35 \mathrm{~km}$ east of Interstate Highway 80.

Remoteness: $32 \mathrm{~km}$ southeast of Winnemucca (Humboldt County, population 3,587).

Geologic setting: The Grand Trunk Canyon pluton is composed of a single exposure of Jurassic granite and intrudes the Pennsylvanian to Permian Havallah and Pumpernickel Formations, composed of chert, argillite, shale, greenstone, and minor amourits of siltstone, sandstone, conglomerate, and limestone. The structure consists of north-northwest-trending high-angle normal faults and a complex thrust fault system.

Hydrologic setting: The pluton is in the Humboldt River Basin ground-water system, and drainage reaches the river via the Grass Valley tributary. The nearest discharge is $10 \mathrm{~km}$ west of the center of outcrop, and water is used in Grass Valley mainly for livestock, domestic, and irrigation purposes.

Aeromagnetic expression: The granitic rock exposures occur in an area of very low magnetic relief. A low-amplitude negative anomaly occurs in the vicinity of the southern outcrop.

Comment: Area lies within the Nevada seismic zone. 
General location: Three exposures--one at the central part of the Tobin Range near Siard Canyon; the second exposure near Needle Peak, Tobin Range; and the third exposure occurs near Jersey Canyon, Fish Creek Mountain.

Coordinates: Northernmost exposure at lat $40^{\circ} 28^{\prime} \mathrm{N}$., long $117^{\circ} 30^{\prime} \mathrm{W}$.

Land classification: Public domain.

Area: $5 \mathrm{~km}^{2}$.

Accessibility: $48 \mathrm{~km}$ east of State Highway 50 and $8 \mathrm{~km}$ east of an improved surface road. Remoteness: Northernmost exposure is $60 \mathrm{~km}$ southeast of Winnemucca (Humboldt County, population 3,587).

Geologic setting: The Tobin pluton is composed of Jurassic granite. The granite intrudes Pennsylvanian to Permian Havallah and Pumpernickel Formations and is composed of chert, argillite, shale, greenstone, and minor amounts of siltstone, sandstone, conglomerate, and limestone. The granite has been dated at 153 \pm 3 m.y. (Silberman and McKee, 1971).

The Tobin Range is a northeast-trending range that has been uplifted and is bounded on both sides by high-angle normal faults. There are two systems of normal faults; one trends north-northeast, and the other northwest. Thrust faults also occur in the range.

The pluton is located northeast of the site of an earthquake in Pleasant Valley that occurred on 0ctober 2, 1915. The earthquake resulted in surface breakage along a fault located at the base of the Tobin Range.

Hydrologic setting: The pluton is in the Humboldt River Basin and Dixie Valley ground-water systems. Runoff goes to both Buffalo and Pleasant Valleys. The nearest discharge point is $10 \mathrm{~km}$ east, where the water is used mainly for livestock watering.

Aeromagnetic expression: The granitic rock exposure occurs on the northeastern flank of an elliptical short-wavelength positive anomaly. The maximum areal extent of the buried part of the source is estimated to be about $1 \mathrm{~km}^{2}$.

Comment: The pluton is located in the Nevada seismic zone and near the site of an earthquake that occurred in 1915.

Selected reference: Silberman and McKee, 1971. 
GEOLOGY

The adjoining counties of Washoe, Storey, and Douglas and Carson City (Independent City, formerly Ormsby County) (fig. 18) are located along the northwestern border of the State of Nevada. The three counties and Carson City have been grouped, mainly because they are all situated along a transition zone between the Sierra Nevada and the Basin and Range provinces. Moreover, a few of the granitic exposures of batholithic dimensions extensively overlap into these adjacent counties. One such batholith is the Carson Range, where a continuous granite mass occupies substantial surface area in three adjoining "counties."

Igneous, metamorphic, and sedimentary rocks, ranging in age from Permian(?) to Quaternary are exposed within the "four-county" area. The oldest rocks consist of metamorphosed volcanic and sedimentary strata that have been intruded by bodies of granitic rocks of late Mesozoic age. The Mesozoic metasediments commonly consist of slate, phyllite, metatuff, argillite, quartzite, recrystallized limestone, and hornfels. Metavolcanics include regionally and thermally metamorphosed flows, breccias, and pyroclastics ranging from basalt to rhyolite in composition. Extensive areas throughout the counties are covered by Tertiary rocks that chiefly consist of basaltic, andesitic, and rhyolitic flows, breccias, and pyroclastics with intercalated lenses of sedimentary rocks.

Granodiorite and quartz monzonite are the most abundant types of granitic rocks, although alaskite and granite porphyry are also present. Several textural phases have been noted in the granodiorite, the most common being porphyritic granodiorite. Quartz monzonite and granodiorite intrusions of Miocene and (or) Pliocene age are present at several localities in southern washoe and Storey Counties. These Tertiary plutons commonly exhibit weak to intense hydrothermal alteration.

Geologic evidence available from rock exposures indicates two main deformational episodes. The first episode began in late Mesozoic time and the second commenced in late Tertiary, continuing into the Quaternary age. Late Mesozoic structure is represented by folds, faults, and low-grade regional metamorphism prior to intrusion of granitic plutons in the Cretaceous(?) Period.

A late period of deformation probably began in the middle to late Tertiary and has continued into the Quaternary. Structural features associated with this episode include normal faults, strike-slip displacement, and folds related to strike-slip movement. The Walker Lane Fault Zone is the dominant Cenozoic structural element in Washoe and Storey Counties, although movement may have begun in Early Jurassic time. This strike-slip zone extends northwestward through Washoe County from the vicinity of Wadsworth to Honey Lake Valley near Flanigan. The latest detectable displacement along the fault occurred in the late Pleistocene (Bonham, 1969).

Most of the geologic data summarized herein has been abstracted from two principal published sources:

Bonham, 1969; Moore, 1969. 


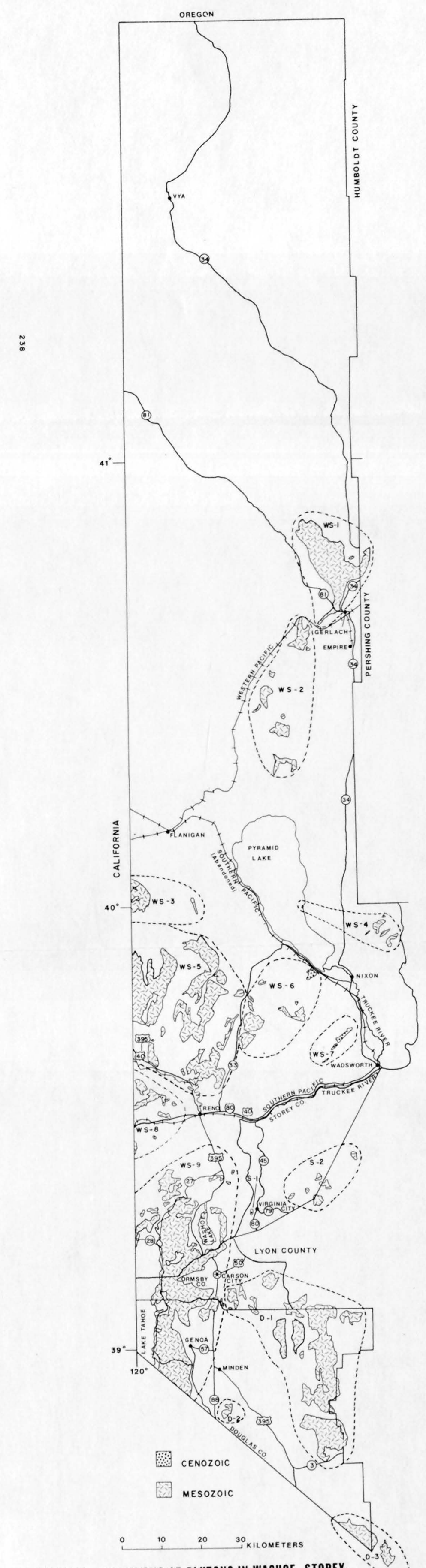

FIGURE 18.- LOCATIONS OF PLUTONS IN WASHOE, STOREY, AND DOUGLAS COUNTIES AND CARSON CITY (INDEPENDENT CITY) 
The southern half of this group of counties is drained by the West Walker, Carson, and Truckee Rivers; these streams derive most of their runoff from the Sierra Nevada in California. The northern half of Washoe County drains into topographically closed depressions, chiefly Honey Lake Valley (partly in California), and Smoke Creek, San Emidio, and Black Rock Deserts, Hualapai Flat, Duck Flat, Long Valley, and Coleman Valley (partly in Oregon).

Chief sources of moisture for recharge and runoff within the south area of this group of counties are Wellington Hills, Pine Nut Mountains, Carson Range, and Pah Rah Range. A11 the scattered peaks over $1,981 \mathrm{~m}$ in elevation north of the Smoke Creek Desert are sources of recharge and runoff.

Walker Lake, Carson River Basin, and Truckee River Basin ground-water systems underlie most of the southern half of the four-county group; ground-water flow that parallels tributary drainage is the dominant feature of these systems. Black Rock Desert ground-water system underlies Smoke Creek, San Emidio, and Black Rock Deserts and Hualapai Flat; in Washoe County the Black Rock Desert system is in virtual stagnation as the water level throughout the system is almost flat or without a gradient.

Ground-water systems within the northern part of Washoe County--Duck Flat-Surprise Valley, Long Valley, and Coleman Valley--are hydrologically closed, but some water in Coleman Valley moves into Oregon. Ground water along the California boundary moves principally toward California, with a few isolated exceptions.

The hydrology of Washoe, Storey, and Douglas Counties and Carson City was taken from the following references:

Glancy and Katzer, 1976; Glancy and Rush, 1968; Rush, 1967; Rush and Glancy, 1967; Sinclair, 1962c, 1963c, 1963d; VanDenburgh, Lamke, and Hughes, 1973; Worts and Malmberg, 1966. 


\section{WS-1. GRANITE RANGE}

General location: North of Gerlach.

Coordinates: lat $40^{\circ} 46^{\prime} \mathrm{N}$, , long $119^{\circ} 23^{\prime} \mathrm{W}$.

Land classification: Public and private lands, but predominantly public.

Area: $154 \mathrm{~km}^{2}$.

Accessibility: State Highways 81 and 34 pass along the western and eastern flanks of the range, respectively. Highway 34 extends southward and connects with Interstate 80.

The Western Pacific Railroad passes along the southern margin.

Remoteness: The town of Gerlach (population 130) lies $1.5 \mathrm{~km}$ southeast of the southwestern edge of the range. Empire (population 300) is $9 \mathrm{~km}$ south of Gerlach.

Geologic setting: The southern extremity of the Granite Range consists of an extensive exposure of granodiorite of batholithic dimensions. A radiometric-age analysis on biotite was determined to be $88.8(\stackrel{+}{(-2.6)}$ m.y. (Krueger and Schilling, 1971).

Metavolcanic and metasedimentary rocks of Permian(?) and Triassic age are exposed in a narrow band along the northern and parts of the eastern margins of the batholith. These units are exposed in an elevated fault block from which the Tertiary cover has been removed by erosion. These host rocks represent a contact-metamorphosed sequence of volcanic flows, pyroclastics, and limestone that includes metabasalt, meta-andesite flows, breccias, tuffs, and fossiliferous recrystallized limestone.

Most of the western and eastern margins of the granitic mass are marked by high-angle normal faults, bringing Quaternary sediments in contact with the granitic mass. Several normal faults have also been mapped within the central part of the granitic body.

Hydrologic setting: The pluton is in the Black Rock Desert ground-water system, which includes the Smoke Creek Desert and Hualapai Flat areas. Runoff drains to Hualapai Flat, Black Rock Desert, and Smoke Creek Desert. The nearest discharge areas are in Smoke Creek Desert and Hualapai Flat; both about $7 \mathrm{~km}$ from the center of the pluton. Ground water is used in the discharge areas for irrigation, livestock, domestic, and public supply.

Aeromagnetic expression: The granitic rocks clearly are associated with a regional highamplitude positive anomaly. The chevron-shaped bow of the anomaly closely conforms to the major northwest-trending and minor northeast-trending parts of the granitic rock terrane. The northeasttrending part of the anomaly suggests that an additional areal extent of about $50 \mathrm{~km}^{2}$ of granitic rock terrane lies in the subsurface northeast of the mapped contact.

Selected reference: Krueger and Schilling, 1971. 
General location: Southwest of Gerlach.

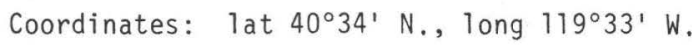

Land classification: Public domain. The southernmost exposure is on the Pyramid Lake Indian Reservation.

Area: $79 \mathrm{~km}^{2}$ (cumulative).

Accessibility: State Highway 34 passes southward $13 \mathrm{~km}$ east of the westernmost exposure. The Western Pacific Railroad passes along the western flank of the range within $4 \mathrm{~km}$ of the western outcrops and adjacent to the northernmost exposure.

Remoteness: The northern exposure is $11 \mathrm{~km}$ west of Empire (population 300) and $11 \mathrm{~km}$ southwest of Gerlach (population 130).

Geologic setting: The Mesozoic granodiorite outcrops, underlying parts of the Fox Range, are of two distinct types. The southern exposures commonly contain less than 10 per cent mafic minerals, whereas the northern outcrops are generally foliated and contain 20 percent mafic minerals. Both types intrude metamorphic rocks generally composed of slate, phyllite, hornfels, recrystallized limestone, and dolomite assigned to the Nightingale sequence (Triassic and Jurassic). The metamorphic rocks surrounding the northern exposures exhibit a higher degree of foliation and metamorphic grade than the metamorphic sequence to the south and are, in part, contemporaneous with emplacement of the foliated granodiorite plutons. Basaltic, andesitic, and dacitic flows cover parts of the granitic rock exposures.

Hydrologic setting: The pluton is principally in the Black Rock Desert ground-water system.

Runoff drains primarily to Smoke Creek and San Emidio Deserts drainage basins. The nearest discharge area is $20 \mathrm{~km}$ northwest in the Smoke Creek Desert; local springs may intercept some ground water. Use of water in the Smoke Creek Desert is for livestock.

Aeromagnetic expression: Although the three southern masses of granitic rock have no readily identifiable magnetic anomalies associated with them, the northernmost mass occurs beneath the flank of a high-amplitude positive anomaly. If this anomaly is exclusively associated with granitic rocks, an additional mass of $10 \mathrm{~km}^{2}$ areal extent may lie in the subsurface. 
General location: West of Pyramid Lake, along California State line.

Coordinates: lat $40^{\circ} 01^{\prime} \mathrm{N}$., long $119^{\circ} 57^{\prime} \mathrm{W}$.

Land classification: Public and private lands.

Area: $31 \mathrm{~km}^{2}$ (cumulative).

Accessibility: The main exposure occupies an area $30 \mathrm{~km}$ northwest of State Highway 33 and

$10 \mathrm{~km}$ south of the Western Pacific Railroad.

Remoteness: The small town of Flanigan (population?) lies $15 \mathrm{~km}$ northeast of the main exposure, and Reno (population 84,000) is $53 \mathrm{~km}$ to the southeast.

Geologic setting: Mesozoic granodiorite, underlying a large part of the Fort Sage Mountains, is overlain by a veneer of Tertiary volcanic rocks assigned to the Pyramid sequence and the Santiago Canyon Tuff. The plutons occur within the Walker Lane Fault Zone, characterized by northwest-trending faults.

Hydrologic setting: The outcrops are in Honey Lake Valley ground-water system, mostly in

California. Runoff drains to Honey Lake Valley, Newcomb Lake Valley, and Dry Valley. The nearest discharge is about $12 \mathrm{~km}$ west in Dry Valley. Water is used for livestock and domestic purposes.

Aeromagnetic expression: The Nevada part of the exposed granitic rocks occurs on the northern flank of a northwest-trending high-amplitude positive anomaly, presumably caused by a combination of intrusive and extrusive rocks.

Comment: An earthquake occurred along one of the northwest-trending faults bounding the southwest flank of the mountains along the California State boundary in 1950 (Gianel1a, 1957).

Selected reference: Gianella, 1957. 


\section{WS-4. NIGHTINGALE DISTRICT (TRUCKEE RANGE)}

General location: East of Pyramid Lake (includes isolated exposure along the east shoreline of Pyramid Lake).

Coordinates: lat N. 39056', long 119016' W. (central location).

Land classification: Public and private lands. Far western outcrop lies on the Pyramid Lake

Area: $12 \mathrm{~km}^{2}$ (cumulative). Indian Reservation.

Accessibility: State Highway 34 is $7.5 \mathrm{~km}$ west of the main eastern exposure, and the Southern Pacific Railroad runs $15 \mathrm{~km}$ southwest of the southern outcrop.

Remoteness: The southern exposure occupies an area $12 \mathrm{~km}$ northeast of Nixon (population 100) and $63 \mathrm{~km}$ northeast of Reno (population 84,000 ).

Geologic setting: Mesozoic granodiorite that crops out in the Nightingale district intrudes metamorphosed sedimentary rocks, predominantly slate, phyllite, hornfels, and recyrstallized limestone assigned to the Nightingale sequence (Triassic and Jurassic). Plutons are also unconformably overlain in places juxtaposed against Tertiary volcanic rocks. Right-lateral strikeslip faults have been mapped in the volcanic rocks $5 \mathrm{~km}$ southwest of the exposures.

Hydrologic setting: The intrusive is in the Truckee River Basin ground-water system, and runoff drains to Winnemucca (dry) Lake and Pyramid Lake. The nearest significant discharge is into Pyramid Lake $12 \mathrm{~km}$ west of the center of the mass; the westernmost exposure is on the Pyramid Lake beach. Water is used for recreation and domestic purposes.

Aeromagnetic expression: Although the southern mass of granitic rocks has no pronounced magnetic expression, the northern masses occur on the flanks of a short-wavelength positive anomaly. The anomaly source may be a composite of intrusive and extrusive rocks. 
General location: North of Reno, along the Nevada-California border. Coordinates: lat $39^{\circ} 40^{\prime} \mathrm{N}$., long $119^{\circ} 52^{\prime} \mathrm{W}$. (central location). Land classification: Public and private lands. Area: $341 \mathrm{~km}^{2}$ (cumulative).

Accessibility: The eastern outcrops are accessible by way of State Highway 33, which extends along the eastern edges of three exposures. An abandoned branch of the Southern Pacific Railroad passes about $14 \mathrm{~km}$ northeast of the northeastern exposure. U.S. Highway 40 (Interstate 80) and a branch of the Southern Pacific Railroad pass along the southern outcrops.

Remoteness: The southern exposures are located within $7.5 \mathrm{~km}$ of Reno (population 84,000), whereas the northern extent of the district lies $45 \mathrm{~km}$ north of Reno.

Geologic setting: Extensive exposures of Mesozoic granodiorite occur within the Stateline Peak district and in areas adjacent to it. The oldest rocks exposed in the area are metavolcanic rocks of Mesozoic age. These rocks are flows, tuffs, and tuffaceous sediments that have been metamorphosed to hornfels and locally to schists along contacts of the intrusions. Intrusives are commonly unconformably overlain by the Santiago Canyon Tuff of Tertiary age and by Pliocene fluviatile and lacustrine sediments. Extensive northwest-trending faults associated with the Walker Lane Fault Zone occur northeast of the area.

Hydrologic setting: The district is within the Lemmon, Warm Springs, and Spanish Springs Valleys ground-water systems and drainage basins. Discharge occurs in three places at the flanks of the exposures about 16-22 km from the approximate geographic center. Local springs and wells intercept some of the ground-water flow. Water is used for irrigation, livestock, domestic, and public supply purposes.

Aeromagnetic expression: Most of the granitic rocks have a complex magnetic signature. Two northwest-trending high-amplitude positive anomalies may be associated with similarly trending areas of outcrop, but the correlative is indefinite because of the possible influence of extrusive rocks. 
General location: South of Pyramid Lake.

Coordinates: lat $39^{\circ} 44^{\prime} \mathrm{N}$., long $119^{\circ} 34^{\prime} \mathrm{W}$. (central location).

Land classification: Private land, northeastern exposure is on the Pyramid Lake Indian

Area: $44 \mathrm{~km}^{2}$ (cumulative).

Reservation.

Accessibility: State Highway 33 extends along the western edge of the exposures, and an

abandoned branch of the Southern Pacific Railroad passes along the northeast-

ern edge of the northernmost outcrop. U.S. Highway 40 (Interstate Highway 80 )

passes $17 \mathrm{~km}$ south of the southernmost exposure.

Remoteness: The southwestern exposure occupies an area $20 \mathrm{~km}$ northeast of Reno (population

$84,000)$.

Geologic setting: Both Mesozoic granodiorite and Cenozoic quartz monzonite crop out within the

Pah Rah Range. The Mesozoic intrusives intrude regionally and thermally

metamorphosed volcanic flows, breccias, and pyroclastic rocks, ranging

from basalt to rhyolite in composition. A Tertiary granitic intrusive

crops out along the northeastern flank of the range. The exposure is

composed of medium-grained quartz monzonite in its central core, grading

to quartz monzonite porphyry along the margins. The stock has been

weakly to intensely hydrothermally altered and is probably Miocene or

Pliocene in age.

Two major fault systems have been mapped in the Pah Rah Range, an eastnortheast-trending system and a northwest-trending system. The northwest-trending fault system is considered to be part of the Walker Lane Fault Zone.

Hydrologic setting: The range is mainly in the Truckee River Basin ground-water system and runoff drains primarily to Pyramid Lake and Warm Springs Valley. The nearest discharge is $12 \mathrm{~km}$ northeast of the center of the exposure, into Pyramid Lake. The northern exposure is adjacent to the lake's beach. Use of water is mainly for recreation and domestic purposes.

Aeromagnetic expression: The granitic rock masses are somewhat vaguely associated with several positive anomalies which are caused in part by exposures of andesitic and basaltic rocks. 


\section{WS-7. OLINGHOUSE DISTRICT}

General location: Northeast of Reno.

Coordinates: lat $39^{\circ} 42^{\prime}$ N., long $119^{\circ} 24^{\prime}$ W. (central location).

Land classification: Public and private lands, except for a few local mining claims.

Area: $6 \mathrm{~km}^{2}$ (cumulative).

Accessibility: The largest outcrop occurs $2.5 \mathrm{~km}$ and $3 \mathrm{~km}$ west of State Highway 34 and an abandoned branch of the Southern Pacific Railroad, respectively. U.S. Highway 40 (Interstate Highway 80 ) 1 ies $10 \mathrm{~km}$ to the south.

Remoteness: The largest exposure is $39 \mathrm{~km}$ northeast of Reno (population 84,000) and $11 \mathrm{~km}$ northwest of Wadsworth (population 250).

Geologic setting: A group of dikes and irregularly shaped Tertiary intrusions of granodiorite porphyry intrude the Tertiary Santiago Canyon Tuff and the Chloropagus Formation of Axelrod (1956). Most of the masses exhibit moderate to intense hydrothermal alteration. The plutons are alined along a major left-lateral strike-slip fault that trends in an east-northeast direction.

Hydrologic setting: The plutons are mostly in the Truckee River Basin ground-water system and runoff drains to the Truckee River. The nearest discharge point is $5 \mathrm{~km}$ east in the Truckee River. Water is used in the valley for public supply, irrigation, domestic, livestock, and recreation purposes.

Aeromagnetic expression: No well-defined anomalies are associated with the exposed rocks. Comment: The Truckee River lies $5 \mathrm{~km}$ to the east.

Selected reference: Axelrod, 1956. 
WS-8. PEAVINE DISTRICT

General location: West of Reno along the California State boundary.

Coordinates: lat $39^{\circ} 34^{\prime} \mathrm{N}$., long $119^{\circ} 55^{\prime}$ W. (main exposure).

Land classification: Private land.

Area: $29 \mathrm{~km}^{2}$.

Accessibility: U.S. Highway 40 (Interstate 80 ) passes along the southern edge of the larger exposures and U.S. Highway 395 passes $5 \mathrm{~km}$ north of the northernmost exposures.

Remoteness: The eastern outcrops occur within $7 \mathrm{~km}$ of Reno (population 84,000).

Geologic setting: Exposures of granodiorite of Mesozoic age found within the Peavine district intrude undifferentiated metavolcanic and metasedimentary rocks assigned to the Peavine sequence (Triassic and Jurassic). The western edges of the outcrops are overlain by a variety of Tertiary volcanic and sedimentary rocks that include Kate Peak and Alta Formations. One of the outcrops of granodiorite within the district has been assigned a Tertiary age and cuts the Tertiary volcanics and older granodiorite.

Hydrologic setting: The district is in the Truckee River Basin ground-water system, and runoff drains primarily to the Truckee River, which is incised in the southcentral part of the exposures. The Truckee River is the nearest discharge point, and water in the river valley is used primarily for irrigation and public supply purposes.

Aeromagnetic expression: Parts of the granitic rock exposures occur on the flanks of an elliptical, northwest-trending, short-wavelength positive anomaly inferred to have a lithologically diverse source.

Comment: The Truckee River lies directly south of the larger exposures. 
WS-9. CARSON RANGE

General location: North and east of Lake Tahoe.

Coordinates: lat $39^{\circ} 10^{\prime} \mathrm{N}$., long $119^{\circ} 53^{\prime} \mathrm{W}$. (central location).

Land classification: In decreasing order of abundance, ownership is private land, national forest, and State lands.

Area: $453 \mathrm{~km}^{2}$ (cumulative).

Accessibility: U.S. Highway 395 extends southward from Reno along the eastern edge of the range and State Highway 28 passes along the eastern edge of Lake Tahoe.

Remoteness: Reno (population 84,000 ) 1ies $15 \mathrm{~km}$ northeast of the northern exposures and Carson City (population 15,468) is located within $3 \mathrm{~km}$ of the eastern edge of the exposure. Several smaller towns are situated along the eastern shore of Lake Tahoe and the eastern flank of the range.

Geologic setting: The Carson Range is a north-trending mountain block that splits off from the Sierran block southwest of the Nevada-California border. Granitic rocks of Jurassic(?) and late Mesozoic age have intruded metasedimentary and metavolcanic rocks of Triassic(?) age. The composition of the batholith is predominantly granodiorite and quartz monzonite. The granitic rocks generally exhibit sharp, discordant intrusive contacts with the older metamorphic rocks.

The northern extent of the mass, within Washoe County, is largely overlain by Tertiary volcanic rocks included within the Kate Peak Formation and Santiago Canyon Tuff. To the south, the range is overlain in places by pre-Tertiary roof pendants. The exposure has very little Tertiary cover, presumably owing to greater uplift and resultant erosion of younger rocks. A recent fault scarp, approximately $13 \mathrm{~m}$ high, exists along the eastern flank of the range.

Hydrologic setting: The range is in several ground-water systems, including Lake Tahoe, Washoe Lake, and Carson River Basin systems. Runoff drains mainly to Lake Tahoe, Washoe Lake, Steamboat Ditch, and Carson River. Discharge occurs at many places within the range. Water is used in the range principally for irrigation, recreation, and public supply.

Aeromagnetic expression: A large percentage of the granitic rock terrane is covered by northtrending positive anomalies. Most of the anomaly producing rocks appear to have exposed upper surfaces.

Comment: Several hot springs are situated along the eastern flank of the range within Douglas and Washoe Counties and Carson City.

Selected references: Thompson and White, 1964; Garside, 1974. 
General location: Northeastern part of Douglas County.

Coordinates: lat $38^{\circ} 59^{\prime}$ N., long $119^{\circ} 27^{\prime} \mathrm{W}$.

Land classification: The area has been designated as public domain, private lands, and

Area: $310 \mathrm{~km}^{2}$ (cumulative).

Indian Trust Allotments.

Accessibility: The northwestern outcrops are within $45 \mathrm{~km}$ of U.S. Highway 50 and $3 \mathrm{~km}$

of U.S. Highway 395. West-central exposures are 10-15 km east of

U.S. Highway 395. The southern extent of the mountains is less than

$1 \mathrm{~km}$ north of State Highway 3.

Remoteness: The northwestern outcrops occupy an area $4.5 \mathrm{~km}$ southeast of Carson City (population 22,500).

Geologic setting: The Pine Nut Mountains are a north-trending mountain block tilted to the west. The intrusive rocks are larglely quartz monzonite, porphyritic quartz monzonite, and granodiorite of late Jurassic and Mesozoic age, which are probably continuous with the Sierra Nevada batholith west of the Carson Range.

An age determination made on a sample of porphyritic quartz monzonite, collected near Mount Como, resultec in an age of $146 \pm 8$ m.y. (Krueger and Schil1ing, 1971).

The granitic rocks cut Triassic and Jurassic metasediments and metavolcanics composed of shale, slate, tuffaceous siltstone, sandstone, graywacke, andesite breccias, tuffs, and flows. Parts of the western slope of the range are overlain by Tertiary lacustrine and fluviatile sediments. Most of the eastern front of the range is marked by a steep fault scarp. Numerous north-treriding high-angle normal faults have also been mapped within the granitic mass.

Hydrologic setting: The mountains are in Carson River Basin and Walker Lake ground-water systems. Runoff drains to the Carson and Walker Rivers. Discharge occurs on all sides and locally within the mountains. Water is used in the river valleys for irrigation, livestock, domestic, and public supplies.

Aeromagnetic expression: The north-trending granitic rock terrane is largely transected by regional northwest-trending positive anomalies having unknown sources. The northernmost (Carson City) and southernmost (Douglas County) bodies appear to serve as sources for two relatively equidimensional positive anomalies.

Mining activity: A gold mine is in operation along the southeastern flank of the mountains. Comment: Thermal springs are present at several localities at the base of the eastern front scarp. Selected reference: Krueger and Schilling, 1971. 


\section{D-2. DRESSLERVILLE}

General location: Western part of Douglas County near the Nevada-California State border. Coordinates: lat $38^{\circ} 52^{\prime}$ N., long $119^{\circ} 44^{\prime}$ W.

Land classification: Private lands and Bureau of Reclamation withdrawals.

Area: $6 \mathrm{~km}^{2}$.

Accessibility: U.S. Highway 395 passes $3.5 \mathrm{~km}$ northeast, and State Highway 88 is $2 \mathrm{~km}$ west of the exposure.

Remoteness: The outcrop is located $9 \mathrm{~km}$ south of Minden (population 400) and $33 \mathrm{~km}$ south of Carson City (population 22,500).

Geologic setting: The pluton is composed of quartz monzonite and granodiorite of late Mesozoic age and is probably continuous with the Sierra Nevada batholith to the west. The pluton intrudes Triassic and Jurassic metavolcanics consisting of andesite breccias, tuffs, flows, basalt, and rhyolite. Numerous normal faults exist within the Tertiary and Quaternary alluvium north of the pluton, and one northeast-trending normal fault cuts the granite mass and extends into the Quaternary alluvium to the southwest.

Hydrologic setting: The pluton is in the Carson River Basin ground-water system and runoff drains to the Carson River. The nearest discharge is in the East Fork of the Carson River, which cuts through the exposure. Water is used in the valley for irrigation, livestock, domestic, and public supplies. Aeromagnetic expression: A short-wavelength high-amplitude positive anomaly is centered at the southern margin of the granitic rock outcrop. The maximum areal extent of that part of the inferred buried source within Nevada is about $1-5 \mathrm{~km}^{2}$. 
General location: Southeast part of Douglas County along Nevada-California border. Coordinates: lat $38^{\circ} 34^{\prime} \mathrm{N}$., long $119^{\circ} 21^{\prime} \mathrm{W}$.

Land classification: Toiyabe National Forest.

Area: $42 \mathrm{~km}^{2}$ (cumulative).

Accessibility: U.S. Highway 395 extends southward into California and passes within $9 \mathrm{~km}$ of the Nevada segment of the granitic mass. State Highway 22, in Lyon County, passes along the eastern slope of the mountains, about $8 \mathrm{~km}$ east of the exposures.

Remoteness: The northern exposures 1 ie $69 \mathrm{~km}$ southeast of Carson City (population 22,500) and $46.5 \mathrm{~km}$ southwest of Yerington (Lyon County, population 2,010).

Geologic setting: The Sweetwater Mountains are a southward continuation of the Pine Nut Mountains. The range extends southward into California, where it merges into the main mass of the Sierra Nevada northwest of Bridgeport. The granitic rock exposures consist of Jurassic(?) and Mesozoic granodiorite and quartz monzonite that cut Triassic and Jurassic metasedimentary and metavolcanic rocks. Most of the margins of the intrusive are marked by high-angle normal faults that bring Tertiary sedimentary and andesitic rocks in fault contact with the masses. Moreover, northwest-trending normal faults cut the granite bodies and extend into the surrounding Tertiary volcanic rocks.

Hydrologic setting: The mountains are in the Walker Lake ground-water system. Runoff drains to the West Walker River drainage basin in Antelope and Smith Valleys. The nearest significant discharge is $25 \mathrm{~km}$ north in Smith Valley. Water is used in the valley for irrigation, livestock, domestic, and public supplies.

Aeromagnetic expression: There is no distinctive anomaly pattern associated with the plutonic rock terrane. 


\section{S-1. COMSTOCK LODE}

General location: West of Virginia City.

Coordinates: lat $39^{\circ} 18^{\prime} \mathrm{N}$. , long $119^{\circ} 39^{\prime} \mathrm{W}$.

Land classification: Private, public, and patented mining claims.

Area: $1 \mathrm{~km}^{2}$.

Accessibility: The outcrop is situated about $1 \mathrm{~km}$ southwest of State Highway 45.

Remoteness: The exposure lies $1 \mathrm{~km}$ west of Virginia City (population 600).

Geologic setting: Within the Comstock Lode there exists a Tertiary granitic stock composed of

the Davidson Granodiorite. This stock intrudes andesite flows, breccias, and pyroclastic rocks of the Tertiary Alta Formation and exhibits pervasive weak to moderate alteration.

Hydrologic setting: The stock is in the Carson River Basin ground-water system. Runoff drains to the Carson River via the Gold Canyon tributary to Dayton Valley. The nearest discharge is $8 \mathrm{~km}$ southeast; local springs may intercept some of the ground-water flow. Water is used in the river valley for irrigation, livestock, domestic, and public supplies.

Aeromagnetic expression: No distinctive anomaly is associated with the small outcrops.

Mining activity: Two lightweight aggregate and perlite mines are in operation along the western flank of the Virginia Range.

Comments: The Comstock Lode is one of the most famous and wel1-publicized precious-metal mining districts in western North America. The total recorded production for the district from 1859 to the present (1969) is $\$ 393,963,725$, virtually all of which was gold and silver (Bonham, 1969).

Selected reference: Thompson, 1956. 
General location: Southeast part of Storey County.

Coordinates: lat $39^{\circ} 21^{\prime} \mathrm{N}$., long $119^{\circ} 30^{\prime} \mathrm{W}$.

Land classification: Private, public, and patented mining claims.

Area: $15 \mathrm{~km}^{2}$ (cumulative).

Accessibility: U.S. Highway 50 crosses the southernmost outcrop in Lyon County. State Highway 79 passes $4 \mathrm{~km}$ southwest of the far western outcrop.

Remoteness: The western exposure lies $8.5 \mathrm{~km}$ northeast of Virginia City (population 600), and

the central outcrop occurs $33 \mathrm{~km}$ southeast of Reno (population 84,000).

Geologic setting: Exposures of granodiorite of Mesozoic age, found along the southeastern flank of the Flowery Range, intrude metasedimentary rocks, slate, phyllite, argillite, quartzite, metagraywacke, and recrystallized limestone assigned to the Peavine sequence (Triassic and Jurassic). Segments of the outcrops are overlain by Tertiary volcanic rocks of the Kate Peak Formation.

Hydrologic setting: The range is in the Carson River Basin ground-water system, and runoff drains primarily to the Carson River. The nearest discharge point is $9 \mathrm{~km}$ southeast in the Carson River. Water is used in the river valley for irrigation, livestock, domestic, and public supplies.

Aeromagnetic expression: Only the westernmost granitic rock exposure has a significant magnetic expression, occurring on the steep eastern flank of a north-trending short-wavelength high-amplitude positive anomaly. The maximum areal extent of the buried source is estimated to be $1-5 \mathrm{~km}^{2}$.

Mining activities: A gold mine is in operation approximately $4 \mathrm{~km}$ south of the westernmost exposure. Lightweight aggregate and perlite are also being mined within the area. 


\section{SELECTED REFERENCES}

Albers, J. P., 1967, Belt of sigmoidal bending and right-lateral faulting in the western Great Basin: Geological Society of America Bulletin, v. 78, no. 2, p. 143-155.

Albers, J. P., and Stewart, J. H., 1972, Geology and mineral deposits of Esmeralda County, Nevada: Nevada Bureau of Mines and Geology, Bulletin 78, 80 p.

Anderson, R. E., 1969, Notes on the geology and paleohydrology of the Boulder City pluton, southern Nevada, in Geological Survey Research, 1969: U.S. Geological Survey Professional Paper 650-B, p. B35-B40.

1973, Large-magnitude late Tertiary strike-slip faulting north of Lake Mead, Nevada:

U.S. Geological Survey Professional Paper 794, 18 p.

Andreasen, G. E., and Zietz, Isidore, 1969, Magnetic fields for a $4 \times 6$ prismatic model: U.S. Geological Survey Professional Paper 666, 9 p.

Armstrong, R. L., 1968, Sevier orogenic belt in Nevada and Utah: Geological Society of America Bulletin 79, p. 429-458.

1970a, Geochronology of Tertiary igneous rocks, eastern Basin and Range province, western Utah, eastern Nevada, and vicinity, USA: Geochimica et Cosmochimica Acta, v. 34, no. 2, p. 203-232.

1970b, K-Ar dating using neutron activation for Ar analysis--Comparison with isotope dilation Ar analyses: Geochimica et Cosmochimica Acta, v. 34, no. 2, p. 233-236.

Axelrod, D. I., 1956, Mio-Pliocene floras from west-central Nevada: University of California, Geologic Science, v. 33, p. 95-97, p. 138-139.

Bath, G. D., 1976, Interpretation of magnetic surveys in intermontane valleys of Nevada and southern New Mexico: U.S. Geological Survey Open-file Report 76-440, 37 p.

Bingler, E. C., and Bonham, H. F., Jr., 1973, Reconnaissance geologic map of McCullough Range and adjacent areas, Clark County, Nevada: Nevada Bureau of Mines and Geology Map 45.

Blankennage1, R. K., and Weir, J. E., Jr., 1973, Geohydrology of the eastern part of Pahute Mesa, Nevada Test Site, Nye County, Nevada: U.S. Geological Survey Professional Paper $712-B, 35$ p.

Bonham, H. F., 1969, Geology and mineral deposits of Washoe and Storey Counties, Nevada: Nevada Bureau of Mines Bulletin $70,140 \mathrm{p}$. 1970, Geologic map and sections of a part of the Shoshone Mountains, Lander and Nye Counties: Nevada Bureau of Mines Map 38.

Brokaw, A. L., 1967, Geologic map and sections of the Ely quadrangle, White Pine County, Nevada: U.S. Geological Survey Geologic Quadrangle Map GQ-697, scale 1:24,000.

Brokaw, A. L., Bauer, H. L., and Breitrick, R. A., 1973, Geologic map of the Ruth quadrangle, White Pine County, Nevada: U.S. Geological Survey Geologic Quadrangle Map GQ-1085, scale $1: 24,000$.

Callaghan, Eugene, 1939, Geology of the Searchlight mining district, Clark County, Nevada: U.S. Geological Survey Bulletin 906-D, p. 135-188.

Callaghan, Eugene, and Gianella, V. P., 1935, The earthquake of January 30, 1934, at Excelsior Mountains, Nevada: Seismological Society of America Bulletin, v. 25, p. 161-168.

Cebul1, S. E., 1967, Bedrock geology of the southern Grant Range, Nye County, Nevada: Seattle, Washington, Washington University Ph.D. Thesis, $130 \mathrm{p}$.

Christiansen, R. L., and Noble, D. C., 1965, Black Mountain volcanism of southern Nevada [abs.]: Geological Society of America Special Paper 82, p. 246. 
Coats, R. R., 1968, Preliminary geologic map of the southwestern part of the Mountain City quadrangle, Elko County, Nevada: U.S. Geological Survey Open-file Map, scale 1:20,000. 1971, Geologic map of the Owyhee quadrangle, Nevada-Idaho: U.S. Geological Survey Miscellaneous Geologic Investigations Map I-665, scale 1:48,000.

Coats, R. R., and Mackenzie, Gordon, Jr., 1972, Tectonic implications of the presence of the Edna Mountain Formation in northern Elko County, Nevada: U.S. Geological Survey Professional Paper 800-C, p. C85-C94.

Coats, R. R., Marvin, R. F., and Stern, T. W., 1965, Reconnaissance of mineral ages of plutons in Elko County, Nevada, and vicinity: U.S. Geological Survey Professional Paper 525-D, p. D11-D15.

Cohen, Philip, 1964, A brief appraisal of the ground-water resources of the Grass Valley area, Humboldt and Pershing Counties, Nevada: Nevada Department of Conservation and Natural Resources, Reconnaissance Series Report 29, 40 p.

Cohen, Philip, ard Everett, D. E., 1963, A brief appraisal of the ground-water hydrology of the Dixie-Fairview area, Nevada: Nevada Department of Conservation and Natural Resources, Reconnaissance Series Report 23, $40 \mathrm{p}$.

Cornwal1, H. R., 1972, Geology and mineral deposits of southern Nye County, Nevada: Nevada Bureau of Mines and Geology, Bulletin 77, 49 p.

Crosthwaite, E. G., 1963, Ground-water appraisal of Antelope and middle Reese River Valleys, Lander County, Nevada: Nevada Department of Conservation and Natural Resources, Reconnaissance Series Report 19, 33 p.

Dudley, W. W., Jr., 1967, Hydrogeology and ground-water flow system of the central Ruby Mountains, Nevada: Champaign, I11., University of 111 inois, Ph.D. Thesis, 107 p.

Eakin, T. E., 1960, Ground-water appraisal of Newark Valley, White Pine County, Nevada: Nevada Department of Conservation and Natural Resources, Reconnaissance Series Report 1, $33 \mathrm{p}$. 1961a, Ground-water appraisal of Pine Valley, Eureka, and Elko Counties, Nevada: Nevada Department of Conservation and Natural Resources, Reconnaissance Series Report 2, $41 \mathrm{p}$. 1961b, Ground-water appraisal of Long Valley, White Pine, and Elko Counties, Nevada: Nevada Department of Conservation and Natural Resources, Reconnaissance Series Report 3, 35 p.

1962a, Ground-water appraisal of Gabbs Valley, Mineral and Nye Counties, Nevada: Nevada Department of Conservation and Natural Resources, Reconnaissance Series Report 9, 27 p. 1962b, Ground-water appraisal of Ralston and Stone Cabin Valleys, Nye County, Nevada: Nevada Department of Conservation and Natural Resources, Reconnaissance Series Report 12, $32 \mathrm{p}$. 1962c, Ground-water appraisal of Diamond Valley, Eureka and Elko Counties, Nevada: Nevada Department of Conservation and Natural Resources, Reconnaissance Series Report 6 , $60 \mathrm{p}$. 1962d, Ground-water appraisal of the Imlay area, Hurnboldt River basin, Pershing County, Nevada: Nevada Department of Conservation and Natural Resources, Reconnaissance Series Report 5, $54 \mathrm{p}$. 
Eakin, T. E., 1962e, Ground-water appraisal of Independence Valley, western Elko County, Nevada: Nevada Department of Conservation and Natural Resources, Reconnaissance Series Report 8, 31 p.

1962f, Ground-water appraisal of Cave Valley in Lincoln and White Pine Counties, Nevada: Nevada Department of Conservation and Natural Resources, Reconnaissance Series Report 13, 19 p.

1963a, Ground-water appraisal of Dry Lake and Delamar Valleys, Lincoln County, Nevada: Nevada Department of Conservation and Natural Resources, Reconnaissance Series Report 16, 26 p.

1963b, Ground-water appraisal of Garden and Coal Valleys, Lincoln and Nye Counties, Nevada: Nevada Department of Conservation and Natural Resources, Reconnaissance Series Report 18, 29 p.

1963c, Ground-water appraisal of Pahranagat and Pahroc Valleys, Lincoln and Nye Counties, Nevada: Nevada Department of Conservation and Natural Resources, Reconnaissance Series Report 21, $36 \mathrm{p}$.

1964, Ground-water appraisal of Coyote Spring and Kane Spring Valleys and Muddy River Springsarea, Lincoln and Clark Counties, Nevada: Nevada Department of Conservation and Natural Resources, Reconnaissance Series Report 25, 40 p. 1966, A regional interbasin ground-water system in the White River area, southeastern Nevada: Water Resources Research, v. 2, no. 2, p. 251-271; reprinted as Nevada Department of Conservation and Natural Resources, Water Resources Bulletin 33, 1966.

Eakin, T. E., Hughes, J. L., and Moore, D. 0., 1967, Water-resources appraisal of Steptoe Valley, White Pine and Elko Counties, Nevada: Nevada Department of Conservation and Natural Resources, Reconnaissance Series Report 42, 48 p.

Eakin, T. E., and Lamke, R. D., 1966, Hydrologic reconnaissance of the Humboldt River basin, Nevada: Nevada Department of Conservation and Natural Resources, Water Resources Bulletin 32, $107 \mathrm{p}$.

Eakin, T. E., and Maxey, G. B., 1951, Ground water in Ruby Valley, Elko and White Pine Counties, Nevada: Nevada State Engineer's Office, Water Resources Bulletin 12, p. 65-93.

Eakin, T. E., Moore, D. 0., and Everett, D. E., 1965, Water-resources appraisal of the upper Reese River Valley, Lander and Nye Counties, Nevada: Nevada Department of Conservation and Natural Resources, Reconnaissance Series Report 31, 46 p.

Eakin, T. E., Price, Don, and Harri11, J. R., 1976, Summary appraisal of the Nation's groundwater resources--Great Basin region: U.S. Geological Survey Professional Paper 813-G, $37 \mathrm{p}$.

Edwards, George, and McLauglin, W. A., 1972, Shel1 1ist no. 1-K-Ar and Rb-Sr age determinations of California, Nevada, and Utah rocks and minerals: Isochron/West, no. 3, p. 1-7.

Ekren, E. B., Anderson, R. E., Rogers, C. L., and Noble, D. C., 1971, Geology of northern Nellis Air Force Base Bombing and Gunnery Range, Nye County, Nevada: U.S. Geological Survey Professional Paper 651, 91 p.

Ekren, E. B., Bucknam, R. C., Carr, W. J., Dixon, G. L., and Quinlivan, W. D., 1976, Easttrending structural lineaments in central Nevada: U.S. Geological Survey Professional Paper 986, 16 p. 
Ekren, E. B., Orkild, P. P., Sargent, K. A., and Dixon, G. L., 1978, Geologic map of Tertiary rocks, Lincoln County, Nevada: U.S. Geological Survey Miscellaneous Investigations Series Map I-1041, scale 1:250,000.

Evans, J. G., and Ketner, K. B., 1971, Geologic map of the Swales Mountain quadrangle and part of the Adobe Summit quadrangle, Elko County, Nevada: U.S. Geological Survey Miscellaneous Geologic Investigations Map I-667, scale 1:24,000.

Everett, D. E., 1964, Ground-water appraisal of Edwards Creek Valley, Churchill County, Nevada: Nevada Department of Conservation and Natural Resources, Reconnaissance Series Report 26, $18 \mathrm{p}$.

Everett, D. E., and Rush, F. E., 1964, Ground-water appraisal of Smith Creek and Ione Valleys, Lander and Nye Counties, Nevada: Nevadä Department of Conservation and Natural Resources, Reconnaissance Series Report 28, 21 p. 1965, Water-resources appraisal of Lovelock Valley, Pershing County, Nevada: Nevada Department of Conservation and Natural Resources, Reconnaissance Series Report 32 , $40 \mathrm{p}$. 1966, A brief appraisal of the water resources of Grass and Carico Lake Valleys, Lander and Eureka Counties, Nevada: Nevada Department of Conservation and Natural Resources, Reconnaissance Series Report 37, 28 p. 1967, A brief appraisal of the water resources of the Walker Lake area, Mineral, Lyon, and Churchill Counties, Nevada: Nevada Department of Conservation and Natural Resources, Reconnaissance Series Report 40, $44 \mathrm{p}$.

Ferguson, H. G., 1924, Geology and ore deposits of the Manhattan district, Nevada: U.S. Geological Survey Bulletin 723, 163 p.

Ferguson, H. G., and Cathcart, S. H., 1954, Geologic map of the Round Mountain quadrangle, Nevada: U.S. Geological Survey Geologic Quadrangle Map GQ-40, scale 1:125,000.

Ferguson, H. G., and Muller, S. W., 1949, Structural geology of the Hawthorne and Tonopah Quadrangles, Nevada: U.S. Geological Survey Professional Paper 216, 53 p.

Ferguson, H. G., Muller, S. W., and Cathcart, S. H., 1954, Geology of the Mina Quadrangle, Nevada: U.S. Geological Survey Geologic Quadrangle Map GQ-45, scale 1:125,000.

Fleck, R. J., 1970, Age and possible origin of the Las Vegas Valley shear zone, Clark and Nye Counties, Nevada [abs.]: Geological Society of America Abstracts with programs, v. 2 , no. 5 , p. 333 .

Garside, L. J., 1974, Geothermal exploration and development in Nevada through 1973: Nevada Bureau of Mines Report 21, 12 p.

Gianella, V. P., 1957, Earthquake and faulting, Fort Sage Mountains, California, December 1950: Seismological Society of America Bulletin, v. 47, no. 3, p. 173-177.

Gianella, V. P., and Callaghan, Eugene, 1934, The earthquake of December 20, 1932, at Cedar Mountain, Nevada, and its bearing on the genesis of Basin and Range structure: Journal of Geology, v. 42, p. 1-22.

Gilluly, James, and Masursky, Harold, 1965, Geology of the Cortez Quadrangle; Nevada: U.S. Geological Survey Bulletin 1175, 117 p. 
Gilluly, James, and Gates, 01cott, 1965, Tectonics and igneous geology of the northern Shoshone Range: U.S. Geological Survey Professional Paper 465, 153 p.

Glancy, P. A., 1968a, Water-resources appraisal of Mesquite-Ivanpah Valley area, Nevada and California: Nevada Department of Conservation and Natural Resources, Reconnaissance Series Report 46, 57 p. 1968b, Water-resources appraisal of Butte Valley, Elko and White Pine Counties, Nevada: Nevada Department of Conservation and Natural Resources, Reconnaissance Series Report 49, $50 \mathrm{p}$. 1971, Water-resources appraisal of Antelope Valley and East Walker area, Nevada and California: Nevada Department of Conservation and Natural Resources, Reconnaissance Series Report 53, 69 p.

Glancy, P. A., and Katzer, T. L., 1976, Water-resources appraisal of the Carson River basin, western Nevada: Nevada Department of Conservation and Natural Resources, Reconnaissance Series Report 59, 126 p.

Glancy, P. A., and Rush, F. E., 1968, Water-resources appraisal of Smoke Creek-San Emidio Desert area, Nevada and California: Nevada Department of Conservation and Natural Resources, Reconnaissance Series Report 44, 57 p.

Glancy, P. A., and VanDenburgh, A. S., 1969, Water-resources appraisal of the lower Virgin River Valley area, Nevada, Arizona, and Utah: Nevada Department of Conservation and Natural Resources, Reconnaissance Series Report 51, 87 p.

Granger, A. E., Be11, M. M., Simmons, G. C., and Lee, Florence, 1957, Geology and mineral resources of Elko County, Nevada: Nevada Bureau of Mines Bulletin 54, 190 p.

Gumper, F. J., and Scholz, Christopher, 1971, Microseismicity and tectonics of the Nevada seismic zone: Seismological Society of America Bulletin, v. 61, no. 5, p. 1413-1432.

Hamilton, Warren, 1969, Mesozoic California and the underflow of Pacific mantle: Geological Society of America Bulletin, v. 80, p. 2409-2429.

Harrill, J. R., 1970, Water-resources appraisal of the Granite Springs Valley area, Pershing, Churchi11, and Lyon Counties, Nevada: Nevada Department of Conservation and Natural Resources, Reconnaissance Series Report 55, 35 p. 1971, Water-resources appraisal of the Pilot Creek Valley area, Elko and White Pine Counties, Nevada: Nevada Department of Conservation and Natural Resources, Reconnaissance Series Report 56, 46 p.

Harri11, J. R., and Moore, D. 0., 1970, Effects of ground-water development on the water regimen of Paradise Valley, Humboldt County, Nevada, 1948-68, and hydrologic reconnaissance of the tributary areas: Nevada Department of Conservation and Natural Resources, Water Resources Bulletin 39, 123 p.

Harri11, J. R., and Worts, G. F., Jr., 1968, Estimated water use in Nevada: Nevada Department of Conservation and Natural Resources, Water Resources Information Series Report 7, 37 p.

Harrold, J. L., 1972, K-Ar dates for plutonic rocks, Humboldt County, Nevada, and Harney County, Oregon: Isochron/West, no. 5, p. 1-5.

Hewett, D. F., 1956, Geology and mineral resources of the Ivanpah Quadrangle, California and Nevada: U.S. Geological Survey Professional Paper 275, 172 p. 
Hood, J. H., and Rush, F. E., 1965, Water resources appraisal of the Snake Valley area, Utah and Nevada: Nevada Department of Conservation and Natural Resources, Reconnaissance Series Report 34, 43 p.

Hope, R. A., 1970, Preliminary geologic map of Elko County, Nevada: U.S. Geological Survey Open-file Map 76-779, scale 1:100,000.

Hose, R. K., Blake, M. C., Jr., and Smith, R. M., 1976, Geology and mineral resources of White Pine County, Nevada: Nevada Bureau of Mines and Geology Bulletin 85, 105 p.

Huxel, C. J., Jr., 1969, Water resources and development in Mason Valley, Lyon and Mineral Counties, Nevada, 1948-65: Nevada Department of Conservation and Natural Resources, Water Resources Bulletin 38, 77 p.

Johnson, M. G., 1977, Geology and mineral deposits of Pershing County, ilevada: Nevada Bureau of Mines and Geology Bulletin 89, 115 p.

Kleinhamp1, F. J., and Ziony, J. I., 1967, Preliminary geologic map of northern Nye County, Nevada: U.S. Geological Survey Open-file Map, scale 1:200,000.

Knopf, Adolph, 1921, Ore deposits of Cedar Mountain, Mireral County, Nevada: U.S. Geological Survey Bulletin 725, p. 361-382. 1922, The Candelaria Silver district, Nevada: U.S. Geological Survey Bulletin 735, p. 1-22.

Krueger, H. W., and Schil1ing, J. H., 1971, Geochron/Nevada Bureau of Mines, K/Ar age determinations; List 1: Isochron/West, no. 1, p. 9-14.

Lee, D. E., Marvin, R. F., Stern, T. W., and Peterman, Z. E., 1970, Modification of K/Ar ages by Tertiary thrusting in the Snake Range, White Pine County, Nevada, in Geological Survey Research, 1970: U.S. Geological Survey Professional Paper 700-D, p. D92-D102.

Locke, Augustus, Billingley, P. R., and Mayo, E. B., 1940, Sierra Nevada tectonic patterns: Geological Society of America Bulletin, v. 51, no. 4, p. 513-540.

Loeltz, 0. J., and Malmberg, G. T., 1961, The ground-water situation in Nevada, 1960: Nevada Department of Conservation and Natural Resources, Ground-Water Resources Information Series Report 1, 20 p.

Loeltz, 0. J., and Phoenix, D. A., 1955, Geology and ground-water resources of Buena Vista Valley, Pershing County, Nevada: Nevada Department of Conservation and Natural Resources, Water Resources Bulletin 13, 51 p.

Longwe11, C. R., 1951, Megabreccia developed downslope from large faults: American Journal of Science, v. 249, p. 343-355.

1963, Reconnaissance geology between Lake Mead and Javis Dam, Arizona-Nevada, in Shorter contributions to general geology: U.S. Geological Survey Professional Paper 374-E, p. E1-E51.

Longwe11, C. R., Pampeyan, E. H., Bowyer, Ben, and Roberts, R. J., 1965, Geology and mineral deposits of Clark County, Nevada: Nevada Bureau of Mines, Bulletin 62, $218 \mathrm{p}$.

Lovejoy, D. W., 1959, Overthrust Ordovician and the Nannie's Peak intrusive, Lone Mountain, Elko County, Nevada: Geological Society of America Bulletin, v. 70, no. 5, p. 539-564.

Lumsden, W. W., Jr., 1964, Geology of the southern White Pine Range and northern Horse Range, Nye and White Pine Counties, Nevada: Los Angeles, California, California University, Ph.D. Thesis, 249 p. 
Lutsey, I. A., and Nichols, S. L., 1972, Land status map of Nevada: Nevada Bureau of Mines and Geology, Map 40, scale 1:500,000.

Malmberg, G. T., 1965, Available water supply of the Las Vegas ground-water basin, Nevada: U.S. Geological Survey Water-Supply Paper 1780, 116 p.

1967, Hydrology of the valley-fill and carbonate rock reservoirs, Pahrump Valley, Nevada-California: U.S. Geological Survey Water-Supply Paper 1832, 47 p.

Malmberg, G. T., and Eakin, T. E., 1962, Ground-water appraisal of Sarcobatus Flat and 0asis Valley, Nye and Esmeralda Counties, Nevada: Nevada Department of Conservation and Natural Resources, Reconnaissance Series Report 10, 39 p.

McKee, E. J., 1972, Preliminary geologic map of the Wildcat Peak quadrangle and the western part of the Dianas Punch Bowl quadrangle, Nevada: U.S. Geological Survey Miscellaneous Field Studies Map MF-337, scale 1:62,500.

Mckee, E. H., and Marvin, R. F., 1976, Summary of radiometric ages of Tertiary volcanic and selected plutonic rocks in Nevada, Part 5: Northeastern Nevada: Isochron/West, no. 16, p. 15-27.

Means, W. D., 1962, Structure and stratigraphy in the central Toiyabe Range, Nevada: California University, Publications Geological Sciences, v. 42, no. 2, p. 71-110.

Merriam, C. W., and Anderson, C. A., 1942, Reconnaissance survey of the Roberts Mountains, Nevada: Geological Society of America Bulletin, v. 53, no. 12, p. 1675-1727.

Mifflin, M. D., 1968, Delineation of ground-water flow systems in Nevada: University of Nevada, Desert Research Institute, Technical Report Series H-W, Publication 4, $111 \mathrm{p}$.

Miller, W. M., and Silberman, M. L., 1977, Cretaceous K-Ar age of hydrothermal alteration at the North Fish Creek porphyry copper prospect, Fish Creek Mountains, Lander County, Nevada: Isochron/West, no. 18, p. 7.

Misch, Peter, and Hazzard, J. C., 1962, Stratigraphy and metamorphism of Late Precambrian rocks in central northeastern Nevada and adjacent Utah: American Association of Petroleum Geologists Bulletin, v. 46, no. 3, p. 289, 302-303.

Moore, D. O., and Eakin, T. E., 1968, Water-resources appraisal of the Snake River basin in Nevada: Nevada Department of Conservation and Natural Resources, Reconnaissance Series Report 48, 103 p.

Moore, J. G., 1969, Geology and mineral deposits of Lyon, Douglas, and Ormsby Counties, Nevada, with a section on Industrial minerals by N. L. Archbold: Nevada Bureau of Mines Bulletin $75,45 \mathrm{p}$.

Moores, E. M., 1963, Geology of the Currant area, Nye County, Nevada: Princeton, New Jersey, Ph.D. Thesis, 208 p.

Moores, E. M., Scott, R. B., and Lumsden, W. W., 1968, Tertiary tectonics of the White PineGrant Range region, east-central Nevada, and some regional implications: Geological Society of America Bulletin, v. 79, p. 1703-1726.

Muffler, L. J. P., 1964, Geology of the Frenchie Creek Quadrangle, north-central Nevada: U.S. Geological Survey Bulletin 1179, 99 p.

Noble, D. C., Kister, R. W., Christiansen, R. L., Lipman, P. W., and Poole, F. G., 1965, Close association in space and time of alkalic, calc-alkalic, and calcic volcanism in southern Nevada [abs.]: Geological Society of America Special Paper No. 82, p. 143-144.

Nolan, T. B., 1962, The Eureka mining district, Nevada: U.S. Geological Survey Professional Paper 406, $78 \mathrm{p}$.

Nolan, T. B., Merriam, C. W., and Blake, M. C., Jr., 1974, Geologic map of the Pinto Summit quadrangle, Eureka and White Pine Counties, Nevada: U.S. Geological Survey Miscellaneous Investigations Map I-793, scale 1:31,680. 
Payne, A. L., and Papke, K. G., 1977, Active mines and oil fields in Nevada, 1976: Nevada Bureau of Mines and Geology Map 55, scale 1:1,000,000.

Phoenix, D. A., and Cathcart, J. B., 1952, Quicksilver deposits in the southern Pilot Mountains, Mineral County, Nevada: U.S. Geological Survey Bulletin 973-D, p. 143-171.

Rand McNally and Company, 1977, Rand McNally Road Atlas, 53d Annual Edition: Chicago, I1l., $112 \mathrm{p}$.

Roberts, R. J., Montgomery, K. M., and Lehner, R. E., 1967, Geology and mineral resources of Eureka County, Nevada: Nevada Bureau of Mines Bulletin 64, 152 p.

Rogers, A. M., Perkins, D. M., and Mckeown, F. A., 1977, A preliminary assessment of the seismic hazard of the Nevada Test Site region: Seismological Society of America Bulletin, v. 67, no. 6, p. 1587-1606.

Ross, D. C., 1961, Geology and mineral deposits of Mineral County, Nevada: Nevada Bureau of Mines and Geology Bulletin 58, 98 p.

Rush, F. E., 1964, Ground-water appraisal of the Meadow Valley area, Lincoln and Clark Counties, Nevada: Nevada Department of Conservation and Natural Resources, Reconnaissance Series Report 27, 43 p. 1967, Water-resources appraisal of Washoe Valley, Nevada: Nevada Department of Conservation and Natural Resources, Reconnaissance Series Report 41, 39 p. 1968a, Index of hydrographic areas: Nevada Department of Conservation and Natural Resources, Water Resources Information Series Report 6, 38 p. 1968b, Water-resources appraisal of Clayton Valley-Stonewall Flat area, Nevada and California: Nevada Department of Conservation and Natural Resources, Reconnaissance Series Report 45, 54 p.

1968c, Water-resources appraisal of Thousand Springs Valley, Elko County, Nevada: Nevada Department of Conservation and Natural Resources, Reconnaissance Series Report 47, $61 \mathrm{p}$. 1968d, Water-resources appraisal of the lower Moapa-Lake Mead area, Clark County, Nevada: Nevada Department of Conservation and Natural Resources, Reconnaissance Series Report 50, 66 p. 1970, Regional ground-water systems in the Nevada Test Site area, Nye, Lincoln, and Clark Counties, Nevada: Nevada Department of Conservation and Natural Resources, Reconnaissance Series Report 54, 25 p. 1974, Static groundwater levels of Nevada: Nevada Department of Conservation and Natural Resources, State Water Plan Map, scale 1:750,000

Rush, F. E., and Eakin, T. E., 1963, Ground-water appraisal of Lake Valley in Lincoln and White Pine Counties, Nevada: Nevada Department of Conservation and Natural Resources, Reconnaissance Series Report 24, 29 p.

Rush, F. E., and Everett, D. E., 1964, Ground-water appraisal of Monitor, Antelope, and Kobeh Valleys, Nevada: Nevada Department of Conservation and Natural Resources, Reconnaissance Series Report 30, 45 p.

1966a, Water-resources appraisal of the Huntington Valley area, Elko and White Pine Counties, Nevada: Nevada Department of Conservation and Natural Resources, Reconnaissance Series Report 35, $40 \mathrm{p}$.

1966b, Water-resources appraisal of Little Fish Lake, Hot Creek, and Little Smoky Valleys, Nevada: Nevada Department of Conservation and Natural Resources, Reconnaissance Series Report 38, $38 \mathrm{p}$.

Rush, F. E., and Glancy, P. A., 1967, Water-resources appraisal of the Warm Springs-Lemmon Valley area, Washoe County, Nevada: Nevada Department of Conservation and Natural Resources, Reconnaissance Series Report 43, 70 p. 
Rush, F. E., and Huxel, C. J., Jr., 1966, Ground-water appraisal of the Eldorado-Piute Valley area, Nevada and California: iNevada Department of Conservation and Natural Resources, Reconnaissance Series Report 36, 29 p.

Rush, F. E., and Katzer, T. L., 1973, Water-resources appraisal of Fish Lake Valley, Nevada and California: Nevada Department of Conservation and Natural Resources, Reconnaissance Series Report 58, 70 p.

Rush, F. E., and Kazmi, S. A. T., 1965, Water-resources appraisal of Spring Valley, White Pine and Lincoln Counties, Nevada: Nevada Department of Conservation and Natural Resources, Reconnaissance Series Report 33, 36 p.

Rush, F. E., and Schroer, C. V., 1970, Water resources of Big Smoky Valley, Lander, Nye, and Esmeralda Counties, Nevada: Nevada Department of Conservation and Natural Resources, Water Resources Bulletin 41, 84 p.

Rya11, A., Slemmons, D. B., and Geoney, L. D., 1966, Seismicity, tectonism, and surface faulting in the western United States during historic time: Seismological Society of America Bulletin, v. 56, p. 1105-1135.

Schilling, J. H., 1965, Isotopic age determinations of Nevada rocks: Nevada Bureau of Mines, Report 10, 79 p.

Scott, B. R., Smales, T. J., Rush, F. E., and VanDenburgh, A. S., 1971, Water for Nevada: Nevada Department of Conservation and Natural Resources, Water Planning Report 3, $87 \mathrm{p}$.

Sharp, R. P., 1942, Stratigraphy and structure of the southern Ruby Mountains, Nevada: Geological Society of America Bulletin, v. 53, p. 647-690.

Shawe, D. R., 1965, Strike-slip control of Basin-Range structure indicated by historical faults in western Nevada: Geological Society of America Bulletin, v. 76, p. 1361-1378.

Silberling, N. J., 1959, Pre-Tertiary stratigraphy and upper Triassic paleontology of the Union district, Shoshone Mountains, Nevada: U.S. Geological Survey Professional Paper 322, $67 \mathrm{p}$.

Silberman, M. L., Berger, B. R., and Koski, R. A., 1974, K-Ar age relations of granodiorite emplacement and tungsten and gold mineralization near the Getchell Mine, Humboldt County, Nevada: Economic Geology, v. 69, p. 646-656.

Silberman, M. L., Bonham, H. F., Jr., Garside, L. J., and Osborne, D. H., 1975, New K-Ar ages of volcanic and plutonic rocks and ore deposits in western Nevada: Isochron/West, no. 13, p. 13-21.

Silberman, M. L., and McKee, E. H., 1971, K-Ar ages of granitic plutons in north-central Nevada: Isochron/West, no. 1, p. 15-32:

Silberman, M. L., Wrucke, C. T., and Armbrustmacher, T. G., 1969, Age of mineralization and intrusive relations at Tenabo, Northern Shoshone Range, Lander County, Nevada [abs.]: Geological Society of America, Abstracts with Programs, Part 3, p. 62.

Sinclair, W. C., 1962a, Ground-water resources of Pine Forest Valley, Humboldt County, Nevada: Nevada Department of Conservation and Natural Resources, Reconnaissance Series Report 4, $23 \mathrm{p}$.

1962b, Ground-water resources of Desert Valley, Humboldt and Pershing Counties, Nevada: Nevada Department of Conservation and Natural Resources, Reconnaissance Series Report 7, 23 p. 1962c, Ground-water resources of Hualapai Flat, Washoe, Pershing, and Humboldt Counties, Nevada: Nevada Department of Conservation and Natural Resources, Reconnaissance Series Report 11, $16 \mathrm{p}$. 1963a, Ground-water appraisal of the Black Rock Desert area northwestern Nevada: Nevada Department of Conservation and Natural Resources, Reconnaissance Series Report 20, 32 p. 
Sinclair, W. C., 1963b, Ground-water appraisal of the Pueblo Valley-Continental Lake region, Humboldt County, Nevada: Nevada Department of Conservation and Natural Resources, Reconnaissance Series Report 22, 25 p. 1963c, Ground-water appraisal of the Long Valley-Massacre Lake region, Washoe County, Nevada: Nevada Department of Conservation and Natural Resources, Reconnaissance Series Report 15, 26 p. 1963d, Ground-water appraisal of Duck Lake Valley, Washoe County, Nevada: Nevada Department of Conservation and Natural Resources, Reconnaissance Series Report 17, 19 p.

Slemmons, D. B., 1957, Geological effects of the Dixie Valley-Fairview Peak, Nevada, earthquakes of December 16, 1954: Seismological Society of America Bulletin, v. 47, p. 353-375.

Smith, J. G., McKee, E. H., Tatlock, D. B., and Marvin, R. F., 1971, Mesozoic granitic rocks in northwestern Nevada--a link between the Sierra Nevada and Idaho batholith: Geological Society of America Bulletin, v. 82, p. 2933-2944.

Snyder, C. T., Hardman, George, and Zdenek, F. F., 1964, Pleistocene lakes in the Great Basin: U.S. Geological Survey Miscellaneous Geologic Investigations Map I-416.

Speed, R. C., and Armstrong, R. L., 1971, Potassium-argon ages of some minerals from igneous rocks of western Nevada: Isochron/West, no. 1, p. 1-8.

Steele, Grant, 1960, Pennsylvanian-Permian stratigraphy of east-central Nevada and adjacent Utah: Intermountain Association of Petroleum Geologists, Guidebook 11th Annual Field Conference, p. 93, 102, 104.

Stewart, J. H., and Carlson, J. E., 1974, Preliminary geologic map of Nevada: U.S. Geological Survey Miscellaneous Field Studies Map MF-609.

1978, Geologic map of Nevada: Prepared by U.S. Geological Survey in cooperation with the Nevada Bureau of Mines and Geology, scale $1: 1,000,000$.

Stewart, J. H., and McKee, E. H., 1977, Geology and mineral deposits of Lander County, 'Nevada, Part I, Geology: Nevada Bureau of Mines and Geology, Bulletin 88, p. 1-59.

Stewart, J. H., Walker, G. W., and Kleinhampl, F. J., 1975, Oregon-Nevada 1ineament: Geology, v. 3 , no. 5 , p. 265-268.

Sweeney, R. E., Godson, R. H., Hassemer, J. H., Dansereau, D. A., and Bhattacharyya, B. K., 1978, Composite aeromagnetic map of Nevada: U.S. Geological Survey Open-file Report 78-695, scale $1: 500,000$.

Tatlock, D. B., 1969, Preliminary geologic map of Pershing County, Nevada: U.S. Geological Survey Open-file Report, scale 1:200,000.

Theodore, T. G., Silberman, M. L., and Blake, D. W., 1973, Geochemistry and K-Ar ages of plutonic rocks in the Battle Mountain mining district, Lander County, Nevada: U.S. Geological Survey Professional Paper 798-A, 24 p.

Thomas, H. E., 1964, Water-resources, in Mineral and water resources of Nevada: Nevada Bureau of Mines Bulletin 65, p. 273-314.

Thompson, G. A., 1956, Geology of the Virginia City quadrangle, Nevada: U.S. Geological Survey Bulletin 1042-C, p. 45-77.

Thompson, G. A., and White, D. E., 1964, Regional geology of the Steamboat Springs area, Washoe County, Nevada: U.S. Geological Survey Professional Paper 458-A, p. A1-A52.

Tingley, J. V., 1975, K-Ar dates on granodiorite and related scheelite-bearing quartz veins at Tungsten, Pershing County, Nevada: Isochron/West, no. 12, p. 3-4. 
Tocher, Don, 1956, Movement on the Rainbow Mountain fault [Nev.], in The Fallon-Stillwater earthquakes of JuTy 6, 1954, and August 23, 1954: Seismological Society of America Bulletin, v. 46, no. 1, p. 10-14.

Tschanz, C. M., and Pampeyan, E. H., 1970, Geology and mineral deposits of Lincoln County, Nevada: Nevada Bureau of Mines Bulletin 73, $187 \mathrm{p}$.

U.S. Geological Survey, 1965, State of Nevada: Washington, D.C., U.S. Geological Survey, scale 1:500,000, compiled 1962 .

U.S. Geological Survey, 1974, Hydrologic Unit Map, State of Nevada: Washington, D.C., U.S. Geological Survey, scale 1:500,000.

VanDenburgh, A. S., and Glancy, P. A., 1970, Water-resources appraisal of the Columbus Salt Marsh-Soda Spring Valley area, Mineral and Esmeralda Counties, Nevada: Nevada Department of Conservation and Natural Resources, Reconnaissance Series Report 52, $66 \mathrm{p}$.

VanDenburgh, A. S., Lamke, R. D., and Hughes, J. L., 1973, A brief water-resources appraisal of the Truckee River basin, western Nevada: Nevada Department of Conservation and Natural Resources, Reconnaissance Series Report 57, 122 p.

VanDenburgh, A. S., and Rush, F. E., 1974, Water-resources appraisal of Railroad and Penoyer Valleys, east-central Nevada: Nevada Department of Conservation and Natural Resources, Reconnaissance Series Report 60,61 p.

Vanderburg, W. O., 1937, Reconnaissance of mining districts in Mineral County, Nevada: U.S. Bureau of Mines Information Circular 6941, $79 \mathrm{p}$.

Visher, F. N., 1957, Geology and ground-water resources of Quinn River Valley, Humboldt County, Nevada: Nevada Department of Conservation and Natural Resources, Water Resources Bulletin 14, $56 \mathrm{p}$.

Vitaliano, C. J., 1963, Cenozoic geology and sections of the Ione quadrangle, Nye County, Nevada: U.S. Geological Survey Mineral Investigations Field Studies Map MF-255, scale $1: 62,500$.

Vitaliano, C. J., and Callaghan, Eugene, 1963, Geology of the Paradise Peak quadrangle, Nevada: U.S. Geological Survey Quadrangle Map GQ-250, scale 1:62,500.

Volborth, Alexis, 1962, Rapakivi-type granites in the Precambrian complex of Gold Butte, Clark County, Nevada: Geological Society of America Bulletin, v. 73, p. 813-831. 1973, Geology of the granitic complex of the Eldorado, Newberry, and northern Dead Mountains, Clark County, Nevada: Nevada Bureaũ of Mines and Geology Bulletin 80, p1. 1.

Walker, G. E., and Eakin, T. E., 1963, Geology and ground water of Amargosa Desert, NevadaCalifornia: Nevada Department of Conservation and Natural Resources, Reconnaissance Series Report 14, $57 \mathrm{p}$.

Wel1s, J. D., Elliot, J. E., and Obradovich, J. D., 1971, Age of igneous rocks associated with ore deposits, Cortez-Buckhorn areas, Nevada, in Geological Survey Research 1971: U.S. Geological Professional Paper 750-C, p. C127-C135.

Willden, Ronald, 1964, Geology and mineral deposits of Humboldt County, Nevada: Nevada Bureau of Mines and Geology Bulletin 59, 153 p.

Willden, Ronald, and Speed, R. C., 1974, Geology and mineral deposits of Churchill County, Nevada: Nevada Bureau of Mines and Geology Bulletin 83, 92 p.

Winograd, I. J., and Thordarson, William, 1975, Hydrogeologic and hydrochemical framework, south-central Great Basin, Nevada-California, with special reference to the Nevada Test Site: U.S. Geological Survey Professional Paper 712-C, $126 \mathrm{p.}$

Worts, G. F., Jr., and Malmberg, G. T., 1966, Hydrologic appraisal of Eagle Valley, Ormsby County, Nevada: Nevada Department of Conservation and Natural Resources, Reconnaissance Series Report 39, $55 \mathrm{p}$.

Zietz, Isidore, Stewart, J. H., Gilbert, F. P., and Kirby, J. R., 1977, Aeromagnetic map of Nevada: U.S. Geological Survey Miscellaneous Field Investigations Map MF-902, scale $1: 500,000$. 